\title{
Uitstelduur en praktijkvoering : een onderzoek in een aantal huisartsenpraktijken
}

Citation for published version (APA):

Neven, E. J. J. (1980). Uitstelduur en praktijkvoering : een onderzoek in een aantal huisartsenpraktijken. [Doctoral Thesis, Maastricht University]. Rijksuniversiteit Limburg.

https://doi.org/10.26481/dis.19800425en

Document status and date:

Published: 01/01/1980

DOI:

10.26481/dis.19800425en

Document Version:

Publisher's PDF, also known as Version of record

\section{Please check the document version of this publication:}

- A submitted manuscript is the version of the article upon submission and before peer-review. There can be important differences between the submitted version and the official published version of record.

People interested in the research are advised to contact the author for the final version of the publication, or visit the DOI to the publisher's website.

- The final author version and the galley proof are versions of the publication after peer review.

- The final published version features the final layout of the paper including the volume, issue and page numbers.

Link to publication

\footnotetext{
General rights rights.

- You may freely distribute the URL identifying the publication in the public portal. please follow below link for the End User Agreement:

www.umlib.nl/taverne-license

Take down policy

If you believe that this document breaches copyright please contact us at:

repository@maastrichtuniversity.nl

providing details and we will investigate your claim.
}

Copyright and moral rights for the publications made accessible in the public portal are retained by the authors and/or other copyright owners and it is a condition of accessing publications that users recognise and abide by the legal requirements associated with these

- Users may download and print one copy of any publication from the public portal for the purpose of private study or research.

- You may not further distribute the material or use it for any profit-making activity or commercial gain

If the publication is distributed under the terms of Article $25 \mathrm{fa}$ of the Dutch Copyright Act, indicated by the "Taverne" license above, 


\section{UITSTELDUUR EN \\ PRAKTIJKVOERING}

Een onderzoek in een aantal huisartsenpraktijken 



\title{
UITSTELDUUR EN PRAKTIJKVOERING
}

Een onderzoek in een aantal huisartsenpraktijken

(With a summary in English)

\section{PROEFSCHRIFT}

TER VERKRIJGING VAN DE GRAAD VAN DOCTOR IN DE GENEESKUNDE AAN DE RIJKSUNIVERSITEIT LIMBURG TE MAASTRICHT, OP GEZAG VAN DE RECTOR MAGNIFICUS PROF. DR. W. H. F. W. WUNEN, HOOGLERAAR IN DE FACULTETT DER GENEESKUNDE, VOLGENS BESLUIT VAN HET COLLEGE VAN DEKANEN IN HET OPENBAAR TE VERDEDIGEN IN DE AULA VAN DE UNIVERSITEIT OP VRIJDAG 25 APRIL 1980 DES NAMIDDAGS TE 16.00 UUR

\author{
door \\ EDMOND JOSEPH JOHANNES NEVEN \\ geboren te Heer
}

1980

SCHRIKS' DRUKKERRIJ B.V. - ASTEN (N,-BR.) 
PROMOTORES:

Prof. DR. W. BROUWER

PRoF. DR. H. PHILIPSEN

REFERENTEN:

Prof. Dr. J. C. VAN ES

PROF. DR. W. H. F. W. WIJNEN 
Mijn ouders

Marie-Jeanne Kars

Igor 


\section{Voorwoord}

Het in dit proefschrift beschreven onderzoek werd verricht onder leiding van Professor Dr. W. Brouwer en Professor Dr. H. Philipsen, respectievelijk hoogleraar huisartsgeneeskunde en hoogleraar medische sociologie van de Facullteit der Geneeskunde, Rijksuniversiteit Limburg, Maastricht.

Allen, die bij het tot stand komen van dit proefschrift behulpzaam zijn geweest, ben ik zeer erkentelijk.

Met name ben ik veel dank verschuldigd aan:

Mijn ouders, die mij niet enkel in staat stelden de studie te volgen die in dit proefschrift haar bekroning vindt, doch mij reeds van mijn prille jeugd af wisten te plaatsen in de juiste sfeer en levensovertuiging, die het beroep van medicus vereist;

Professor Dr. W. Brouwer, die ik zeer erkentelijk ben voor het vertrouwen dat hij gedurende deze studie in mij heeft willen stellen en voor de wijze waarop hij dit onderzoek heeft geleid. In de zeer vele uren die wij samen aan dit onderzoek hebben besteed, heb ik - met vallen en opstaan - mogen leren van zijn kritische werkwijze;

Professor Dr. H. Philipsen voor de grondige wijze waarop hij deze dissertatie heeft begeleid. De statistische bewerkingen werden onder zijn leiding uitgevoerd. Zijn scherpe wetenschappelijke visie was voor mij zeer leerzaam;

Protessor Dr. J. C. van Es voor het waardevolle commentaar, dat de kwaliteit van het proefschrift zeer ten goede is gekomen;

Dr. H. K. Muller, die het manuscript heeft bestudeerd en van nuttige adviezen voorzien. Zijn daadwerkelijke hulp in mijn praktijk gaf mij extra gelegenheid me aan dit ondlerzoek te wijden. Voor de prettige wijze waarop hij dit steeds heeft gedaan, wil ik hem in het bijzonder dank zeggen;

Ir. L. W. G. Strijbosch van de Dienst Informatieverwerking van de Rijksuniversiteit Limburg, voor de vele bewerkingen van de uit het onderzoek verkregen gegevens. Als aanvankelijk leek in de statistiek heb ik zijn geduld herhaaldelijk op de proef moeten stellen. Veel heb ik echter van hem mogen leren, waarvoor mijn oprechte dank; 
Alle eenentwintig huisartsen, die aan dit onderzoek hun medewerking hebben verleend. Dit heb ik enorm gewaardeerd. Maar al te goed besef ik welk een belasting dit voor hen betekend heeft. Zonder hun medewerking was dit onderzoek niet mogelijk geweest;

Drs. L. J. M. Melchiors, die de samenvatting heeft vertaald in het Engels; Mej. C. A. M. Brouwers voor haar vele secretaressewerkzaamheden, die zij steeds snel en accuraat uitvoerde.

Het persoonlijk woord tenslotte, dat ik Marie-Jeanne had toegedacht, zal ik liever buiten dit proefschrift spreken.

Gulpen 1980.

De uitgave van dit proefschrift werd mede mogelijk gemaakt door steun van het Nederlands Huisartsen Genootschap. 


\section{Inhoud}

INLEIDING

Hoofdstuk I PROBLEEMSTELLING EN HYPOTHESEN * * . 15

1.1. Probleemstelling . . . . . . . . 15

1.2. Hypothesen. . . . . . . 17

1.2.1. Hypothesen betreffende eigenschappen van de patiënt . 20

1.2.2. Hypothesen betreffende eigenschappen van de klacht . . 24

1.2.3. Hypothesen betreffende eigenschappen van de huisarts en zijm praktijk.

Hoofdstuk II OPZET EN UTTVOERING VAN HET ONDERZOEK . 28

2.1. Inleilding . . . . . . . . . . 28

2.2. Opzet van het onderzoek . . . . . . . . 28

2.3. Uitvoering van het onderzoek . . . . . . 31

2.4. Beschrijving van de variabelen in relatie tot de hypothesen 32

2.4.1. Variabelen met betrekking tot de patiënt. . . . 34

2.4.2. Variabelen met betrekking tot de klacht. . . . 38

2.4.3. Variabelen met betrekking tot de huisarts en zijn praktijk 45

Hoofdstuk III BESCHRIJVING POPULATIE AAN DE HAND VAN DE VARIABELEN . . . . . . . . 50

3.1. Inleiding . . . . . . . . . . 50

3.2. Variabele 1: De uitstelduur . . . . . . . . 53

3.3. Beschrijving populatie aan de hand van kenmerken van de patiënt

3.4. Beschrijving populatie aan de hand vam kenmerken van de klacht

3.5. Beschrijving populatie aan de hand van kenmerken van de huisarts en zijn praktijk . . . . . . . 
Hoofdstuk IV DE TOETSING VAN DE HYPOTHESEN . . . 69

4.1. Inleiding . . . . . . . 69

4.2. Toetsing hypothesen betreffende eigenschappen van de patiënt . . . . . . . . 69

4.3. Toetsing hypothesen betreffende etgenschappen wan de klacht , . . . . . . . . . 79

4.4. Toetsing hypothesen betreffende eigenschappen van de huilsarts en zijn praktijk . . . . . . . 84

4.5. Samenvatting . . . . . . . . . 91

Hoofdstuk V NADERE ANALYSES . . . . . . . 93

5.1. Inleiding . . . . . . . . . . 93

5.2. De variabele: Urgentiegraad van de klacht . . . . 95

5.3. Multipele regressieanalyse . . . . . . . 96

5.4. Contrastgroepenanalyse . . . . . . 100

5.5. Conclusie . . . . . . . . . . 100

5.6. Samenvatting . . . . . . . . 108

Hoofdstuk VI NADERE ANALYSE VAN PATIENTEN DIE LANGER DAN DRIE WEKEN UITSTELDEN EN BESPREKING VAN DE RESULTATEN . . . . . . . 110

6.1. Inleiding . . . . . . . . . . 110

6.2. Nadere analyse van de patiënten die langer dan drie weken
uitstelden

6.3. Bespreking van de resultaten . . . . . . 114

SAMENVATTING . . . . . . . . . . . . 125

SUMMARY . * . . . . . * . . . . . . 134

LITERATUUR . . . . . . * . . . . . 144

BIJLAGEN * . . . . . * * . . . . . 155 


\title{
GEBRUIKTE AFKORTINGEN
}

\author{
1.b.o. = lager beroeps onderwijs \\ $\mathrm{m} . \mathrm{b} . \mathrm{on}_{\mathrm{n}}=$ middelbaar beroepsonderwijs \\ h.b.o. $=$ hoger beroeps onderwijs
}

Statistische symbolen:

Bèta = de gestandaardiseerde regressiecoëfficiënt

$\mathbf{F}=$ de waarde van de $\mathbf{F}$-toets

$\mathrm{N}=$ de populatie-omvang

$\mathbf{P}=$ de overschrijdingskans in de gehanteerde toets

$\mathbf{R}^{2}=$ het percentage verklaarde variantie

Multipele $\mathrm{R}=$ de multipele correlatiecoëfficiënt

Correlatic $\mathrm{O}$-orde $=$ de samenhang tussen twee variabelen zonder rekening te houden met de overige variabelen

Correlatie $\mathrm{n}$-orde $=$ de samenhang tussen twee variabelen waarbij $\mathrm{n}$ variabelen constant zijn gehouden

\section{BIJLAGEN}

Bijllage I : De tijdens bet onderzoek gehanteerde vragenlijst.

Bijlage 11 : De bij de analyse gevonden tabellen, waarbij significante verschillen aantoonbaar zijn.

Bijlage IIr: Automatic Interaction Detection (contrastgroepenanalyse). 


\section{Inleiding}

"Uitstel of afstel is eerder

regel dan uitzondering".

I. K. ZOLA, 1966

Uit morbiditeitsstudies en bevolkingsonderzoekingen blijkt dat niet alle klachten de huisarts bereiken (AULBERS 1970, CASSEE 1973, vAN DEN Dool 1960, van Es 1973, Huygen 1977 en Oliemans 1969). Slechts een beperkt aantal van de onlustgevoelens van de mens komen bij de huisarts terecht.

VAN Es zegt in zijn leerboek „Patiënt en huisarts” 1974 pag. 43: „In dit verband wordt wel het beeld van de ijsberg gebruikt, waarvan slechts de top voor de arts zichtbaar wordt. Inzicht in het zich ,onder water' bevindende deel van de morbiditeit, heeft een meer dan theoretische betekenis. Met name bij die ziekten, waarbij vroegdiagnostiek de kansen op herstel en/of overleving groter maken, is het van belang dat de patiënt geen ,medisch onverantwoord' lang uitstel toont".

In deze studie wordt onder uitstel resp. uitstelduur verstaan, de tijdsduur tussen het moment waarop men een gevoel van onwelzijn resp. een ziekteverschijnsel voor het eerst waarneemt en het moment waarop daarvoor de hulp van de huisarts wordt ingeroepen. Naast dit begrip van ,uitstel' bestaat nòg een betekenis van het woord ,uitstel', waarbij bedoeld wordt ,iets na te laten wat gedaan moet worden'. In deze betekenis wordt het woord ,uitstel' dus niet gebruikt.

Het uitstel kunnen we ook als een meer subjectieve beleving beschouwen.

a. Ervaart de patiënt tijdens dit uitstel gevoelens van ongerustheid, onbehagen of angsten? Hoe ervaart de patiënt het uitstel, en waarom blijft hij uitstellen?

b. Hoe ervaart de naaste omgeving van de patiënt, zoals zijn familie, vrienden en kennissen, zijn uitstel? Maken ook zij zich ongerust? Geven zij de patiënt adviezen en oefenen ze pressie op hem uit, om 
de arts te gaan raadplegen? Hoe is in het algemeen de functie van het gezin ten aanzien van de uitstelduur.

c. Hoe ervaart de arts het uitstel van zijn patiënten? Vindt hij dat zijn patiënten adequaat uitstellen, of vindt hij dat zijn patiënten bij ernstige klachten te lang afwachten en bij minder ernstige klachten de arts te vlug willen raadplegen?

Het ten onrechte niet of te laat inroepen van medische hulp is een probleem waarmee de huisartsgeneeskunde en de gezondheidszorg nogal eens geconfronteerd worden. Speciaal bij optreden van klachten die mogelijk een signaal vormen van een ernstige en/of fatale aandoening, is , medisch onverantwoord' lang uitstel van belang. Opsporing van factoren die dit onverantwoord uitstel beïnvloeden kunnen een bijdrage leveren om te komen tot een meer adequaat en geen schade berokkenend uitstel bij klachten.

Juist in een tijdsperiode waarin preventie en vroege opsporing meer en meer accent krijgen, is het voor de huisartsgeneeskunde van de toekomst van wezenlijk belang, een goed inzicht te verkrijgen in factoren die het uitstel bepalen.

Vele onderzoekers hebben studies verricht, ter verkrijging van meer inzicht in de factoren die het uitstel bepalen. Hierbij is in het algemeen vooral de aandacht gericht geweest op de mens en zijn klachten. Aangezien in Nederland het functioneren van de huisarts ter discussie staat ${ }^{*}$ ), en een versterking van de eerstelijns geneeskunde wordt gepropageerd, leek mij bestudering van het functioneren van de huisarts in relatie tot het uitstel van de patiënt van groot belang.

De laatste 15 jaar heeft zich op het gebied van de praktijkuitoefening een verschuiving gemanifesteerd, die aanvankelijk nog gering was, maar sinds enkele jaren in versneld tempo lijkt door te gaan, nl. de toename van het aantal samenwerkingsverbanden. Hierbij onderscheiden we samenwerkingsverbanden tussen artsen alleen, zoals associaties en groepspraktijken, en samenwerkingsverbanden tussen artsen en medewerkers

*) Zie „Blauwdruk beleid Landelijke Huisartsen Vereniging; een voorstel van het Centraal Bestuur", mei 1975; rapport "Taken van de huisarts", Nederlandls Huisartsen Genootschap, spectale uitgave, juli 1975; "Hoe helpt de dokter?", Nederlands Huisartsen Genootschap, speciale uitgave, juli 1975, en „Kenmerken van de Huisarts", Van Es J.C., e.a., Huisartseninstituut Rijksumiversiteit Utrecht, 1975. 
uit andere disciplines werkzaam in de eerstelijns gezondheidszorg, zoals gezondheidscentra, home-team's, diverse overlegorganen eerstelijns gezondheidszorg.

Onder een associaile verstaan we een samenwerkingsverband tussen twee of meer artsen, waarbij de praktijk voor gemeenschappelijke rekening wordt uitgeoefend.

Onder een groepspraktijk verstaat TEN CATE 1973 pag. 235: „Een praktijk waarin de medische verzorging van een aantal personen plaatsvindt door drie of meer huisartsen, waarbij deze artsen een essentieel gedeelte van hun praktijkvoering gemeenschappelijk verrichten". Onder ,gemeenschappelijke praktijkvoering' verstaat hij, werkend vanuit één praktijk pand en het in dienst hebben van gemeenschappelijk hulppersoneel.

Van een gezondheidscentrum spreken we als meerdere artsen gezondheidszorg biedlen in nauw overleg en samenwerking met andere disciplines zoals maatschappelijk werkers, wijkverpleegsters en fysiotherapeuten, allen werkend vanuit één gemeenschappelijk gebouw. Omstreeks 1963 bestond er in Nederland slechts één groepspraktijk, nl. de Philipsgroepspraktijk te Eindhoven. Tien jaar later waren reeds meer dan 20 groepspraktijken en 9 gezondheidscentra in Nederland werkzaam, waarin $3 \%$ van de Nederlandse huisartsen werkzaam was (TEN CATE 1973). De laatste vijf jaar gaat deze ontwikkeling in versneld tempo voort. In juni 1979 waren in Nederland 45 groepspraktijken en 64 gezondheidscentra werkzaam. Het is daarom van belang na te gaan of, en zo ja in hoeverre, de aard van het samenwerkingsverband invloed heeft op de uitstelduur.

Een andere tendens die de laatste tijd steeds duidelijker waarneembaar wordt, is het houden van afspraakspreekuren.. TEN CATE 1973 pag. 31, heeft berekend dat zonder afspraakspreekuren in geheel Nederland ongeveer 39 miljoen wachturen per jaar bij de huisartsen zouden worden doorgebracht. Hiervan zou ongeveer $40 \%$ ten laste komen van personen, die in het arbeidsproces zijn ingeschakeld. Vele huisartsen gingen over tot het invoeren van afspraakspreekuren. Hoe is echter de invloed van deze spreekuurvorm op de uitstelduur bij klachten van de patiënt?

In bepaald opzicht zien we clat de taak van de huisarts zich uitbreidt. De ontwikkeling van nieuwe praktijkvormen, zoals boven beschreven, vereist meer overlegsituaties zowel tussen artsen onderling als met andere disciplines; bovendien vragen werkzaamheden als anticonceptiecontroles, gesprekstherapie en begeleiding samenhangend met arbeidsongeschiktheid, in toenemende mate aandacht. 
Datrnaast is er ook sprake van een zekere inkrimping. Huisartsen leiden in thet algemeen minder bevallingen dan vroeger, en in de steden behandelen ze minder ongevallen. Bovendien zijn op het platteland minder apotheekhoudende huisartsen werkzaam dan woorheen.

Als huisarts constateert men dat de patiënten lang niet altijd op het juiste moment hun huisarts wensen te raadplegen. Enerzijds zijn er nog altijd patiënten die b.v. met een ,knobbeltje in de borst", of bij ,ophoesten van bloed' of bij, anaal bloedverlies' te lang wachten alvorens hun arts te raadplegen. Anderzijds zijn er ook patiënten die, gezien de aard van de klachten, de hulp van de huisarts onnodig of onnodig vroeg inroepen. Wil men hier verbetering in aanbrengen, dan moet men eerst de oorzaken van dit inadequaat uitstel trachten op te sporen. Ligt de oorzaak grotendeels bij de patiënt, b.v. angst, dan zal een goede voorlichting al veel verbetering kunnen brengen. Mogelijk echter is ook, dat de oorzaak voor een belangrijk deel ligt bij de arts en diens wijze van praktijkvoering. Is, gezien tegen de achtergrond van dit lange uitstel, aan een bepaalde wijze van praktijkvoering de voorkeur te geven? Hebben bijvoorbeeld samenwerkingsverbanden en afspraakspreekuren invloed op de uitstelduur, en zo ja, in hoeverre? Alvorens tot veranderingen in de praktijkvoering over te gaan, lijkt onderzoek hieromtrent aangewezen. Bovenstaande overwegingen vormden de aanleiding tot het bestuderen van de vraag of, en zo ja in hoeverre, samenhang aanwijsbaar is tussen uitstelduur enerzijds en kenmerken van de patiënt, van de klachten en van de arts inclusief diens praktijk, anderzijds. 


\section{Probleemstelling en hypothesen}

\subsection{PROBLEEMSTELLING}

Gedurende mijn zevenjarige praktijkervaring als huisarts in de gemeente Gulpen (Zuid-Limburg) heb ik herhaaldelijk vastgesteld dat patiënten hun arts te laat raadplegen; zie Inleiding.

Verscheidene malen had dit te lange uitstel ook plaats bij klachten die duiden op een ernstige ziekte, zoals bij een ,knobbeltje in de borst', bij ,abnormaal vaginaal bloedverlies', bij ,anaal bloedverlies' of bij het ,ophoesten van bloederig slijm'. In enkele gevallen heeft dit fatale gevolgen gehad.

Dit deed bij mij de vraag rijzen, waarom soms te lang wordt uitgesteld, en hoe hierin misschien verbeteringen zijn aan te brengen. Zou de oorzaak van dit, in de ogen van de arts ,medisch onverantwoord' lang uitstel, behalve bij de patiënt, ook bij de arts en diens wijze van praktijkvoering gelegen kunnen zijn?

Inzicht in de achtergronden van de hulpvraag kan van groot nut zijn voor het bereiken van een adequaat uitstel en een ziektegedrag, dat optimale kansen biedt op herstel.

In het algemeen kunnen we zeggen dat de uitstelduur bepaald wordt door kenmerken van de patiënt en diens omgeving, kenmerken van de klacht en kenmerken van de arts en diens praktijkvoering.

Ten aanzien van de patiënt deed zich de vraag voor of de uitstelduur samenhang vertoont met b.w. de gezinssamenstelling, de socialle status, de bevolkingsaard wat betreft stads- of plattelandsbevolking, de ervaring met de klacht en de frequentie van het doktersbezoek van de patiënt. Ten aanzien van de klacht is mij herhaaldelijk opgevallen dat patiënten, bij klachten gepaard gaande met pijn, niet lang uitstelden. Ook bij klachten, die een aanwijzing konden zijn voor een ernstige ziekte, stelden patiënten in het algemeen niet lang uit. Hebben klachten met een overwegend somatisch karakter een kortere uitstelduur dan klachten met een overwegend psychisch karakter? Is hierbij de persoonlijke instelling van de arts nog van invloed op de uitstelduur? 
Bij klachten van niet acute aard spelen, bij de beslissing de arts te raadplegen, allerlei factoren mee van niet medisch-biologische aard, zoals de kennis van aandoeningen en therapiemogelijkheden, de consultatie van mensen uit de omgeving en de zelfmedicatie. Volgens JESSEN 1974, Medische Consumptie, vertoont een lagere opleiding (met waarschijnlijk minder kennis), samenhang met een langere uitstelduur.

In de periode die voorafgaat aan het doktersbezoek, worden veelal mensen uit de naaste omgeving geraadpleegd. Dit raadplegen vindt vooral plaats in het gezin en bij vrienden en kennissen. Praten met anderen leidt in het algemeen tot een snellere consultatie. Zowel FrendSON 1970 als DUNELL en CARTwRIGHT 1972, constateerden dat zelfmedicatie een alternatief vormt voor de huisartsenconsultatie.

Ten aanzien van de arts en zijn wijze van praktijkvoering werd wel beweerd (KESSEx en SHEPHERD 1965) dat belemmerende factoren als een slechte bereikbaarheid van de arts en volle wachtkamers tijdens het spreekuur, ongunstig kunnen werken op de uitstelduur. Een slechte bereikbaarheid kan samenhangen met een te grote afstand tot het praktijkgebouw, met vervoersproblemen van de patiënt of met onmisbaarheid op het werk of thuis, maar kan ook een gevolg zijn van een niet optimale praktijkorganisatie. Bestaan hieromtrent verschillen in uitstelduur tussen stads- en plattelandspraktijken? Volle wachtkamers vinden vaak hun oorzaak in een slechte praktijkorganisatie of in een overbelasting van de betreffende arts. Is er samenhang tussen afspraakspreekuren en de uitstelduur van de patiënt?

In hoeverre hebben samenwerkingsverbanden nog invioed op de uitstelduur? Men kan zich voorstellen dat bij intensieve onderlinge waarnemingen b.v. avonddiensten vanaf 18.00 uur, de patiënten veelal geen beroep op hun eigen huisarts kunnen doen. Dit kan leiden tot een langer uitstel. Zelf stelde ik herhaaldelijk in mijn praktijk vast, dat patiënten indien ze 's avonds of tijdens de weekenden een beroep moesten doen op een waarnemer, zij er de voorkeur aan gaven tot de volgende ochtend te wachten, waarna ze hun eigen huisarts konden raadplegen.

In hoeverre hebben praktijkgrootte en leeftijd van de arts nog invloed op de uitstelduur? Bij grotere praktijken kan de arts gemiddeld minder tijd per patiënt besteden dan bij kleinere praktijken. Aangaande de leeftijd van de arts kan men veronderstellen dat patiënten oudere huisartsen meer ontzien, en hen vooral 's avonds en 's nachts niet zo vlug willen ,storen'.

$\mathrm{Na}$ bovenstaande beschouwingen komen we tot de volgende algemene probleemstelling: 
In hoeverre hangen kenmerken van de patiènt (als leeftijd, geslacht, opleiding, frequentie huisartsenbezoek, woonplaats en ervaring met de klacht); kenmerken van de klacht (als ernst, pijn, overwegend somatisch of psychisch karakter); en kenmerken wan de arts en diens praktijk (als samenwerkingsverband, spreekuurvorm, praktijkgrootte en leeftijd arts); samen met de uitstelduur?

Aan de hand van deze probleemstelling vindt nu in de volgende paragraaf een formulering van de hypothesen plaats.

\subsection{HYPOTHESEN}

PhILIPSEN 1969, wees erop dat ziek zijn kiezen inhoudt. De ziekteepisode beschreef hij volgens een besliskundig model met terugkoppelingsmogelijkheden. Volgens dit model gaan aan het doktersbezoek een aantal fasen vooraf, zoals het optreden van onwelbevinden, herkenning van gezondheidsproblematiek, de behoefte en de bereidheid om genezing en/of hulp te zoeken. Deze fasering bij het inroepen van deskundige hulp verduidelijkt de aanwezigheid van verschil in uitstelduur.

Uit ervaringen in de praktijk opgedaan blijkt dat de uitstelduur niet steeds constant is. De literatuur doet vermoeden dat er een relatie bestaat tussen de uitstelduur enerzijds, en eigenschappen van de patiënt, van de klacht, en van de arts en diens praktijk anderzijds.

Bij de verdere analyse van de uitstelduur werden wat betreft de kenmerken van de patiënt, in navolging van CASSEE 1973, drie structurele variabelen betrokken: leeftijd, geslacht en opleiding. Deze variabelen zijn eigenlijk de start-variabelen, die hun invloed op de uitstelduur kunnen doen gelden. Vervolgens werd de uitstelduur bekeken in relatie tot de aard van de klacht, en tenslotte werd onderzocht in hoeverre de frequentie van doktersbezoek, woonplaats en eventuele ervaring met de klacht van de patiënt, samenhang vertonen met de uitstelduur.

Het is voor iedereen aannemelijk dat kenmerken van de klacht mede van invloed zijn op de uitstelduur. Kenmerken als de ernst van de klacht en het karakter van de klacht, in de zin van overwegend somatisch of psychisch, kunnen van invloed zijn op de uitstelduur. Het kenmerk ernst van de klacht kan gemakkelijk aanleiding geven tot misverstand of onduidelijkheid. Beoordeling, althans taxatie van de ernst van een klacht, vindt als regel zowel door de patiënt zelf als door de arts plaats. 
Veelal zullen beide een redelijke overeenkomst vertonen, maar ze zijn natuurlijk niet zonder meer als identiek te beschouwen. Het blijkt in de praktijk nogal eens voor te komen dat de een, hetzij de arts, hetzij de patiënt, in de ogen van de ander, de ernst van een klacht over- c.q. onderschat.

Joosten, PHIIPSEN en VAN REEK 1978, verzochten, ten einde tot enige overeenstemming te komen tot de ernst van de klacht, 35 medewerkers van de Medische Faculteit Maastricht, aan de hand van veertig op een vragenlijst (zie bijlage I, vragenlijst) voorkomende klachten, een oordeel te geven over de medische ernst van deze klachten. Aan hen werd de vraag gesteld: „Dient tijdens een eerste consult bij de buisarts elk van de volgende veertig klachten allereerst te worden beschouwd als een uiting van een mogelijk ernstige somatische aandoening?" Hierbij werden vier antwoordcategorieën aangeboden. De bijgevoegde getallen geven de gewichten aan voor de berekeningen.

$3=\mathrm{ja}$, dat is zeker noodzakelijk (ja!)

$2=\mathrm{ja}$, maar het hangt af van de patiënt (ja, maar)

$1=$ neen, maar dit oordeel hangt wel af van de patiënt (neen, maar)

$0=$ neen, dat is niet noodzakelijk (neen!)

\begin{tabular}{lrrrrrrr}
\hline & 3 & 2 & 1 & 0 & Totaal & $\begin{array}{r}\text { Gemid- } \\
\text { deld }\end{array}$ \\
\hline 1. Knobbeltje & 22 & 5 & 5 & 3 & 35 & 2,31 \\
2. Pijn op de borst & 11 & 15 & 9 & - & 35 & 2,06 \\
3. Pijn bij plassen & 16 & 8 & 5 & 5 & 34 & 2,03 \\
4. Benauwdheid & 8 & 17 & 7 & 3 & 35 & 1,86 \\
5. Gewrichtspijin & 8 & 14 & 9 & 4 & 35 & 1,74 \\
6. Dikke enkells & 10 & 12 & 7 & 6 & 35 & 1,74 \\
7. Anaalklachten & 10 & 10 & 7 & 8 & 35 & 1,63 \\
8. Oorpijn & 11 & 7 & 10 & 7 & 35 & 1,63 \\
9. Braken & 8 & 10 & 12 & 5 & 35 & 1,60 \\
10. Maagpijn & 5 & 14 & 11 & 5 & 35 & 1,54 \\
11. Hartkloppingen & 6 & 11 & 14 & 4 & 35 & 1,54 \\
12. Slecht horen & 8 & 12 & 5 & 10 & 35 & 1,51 \\
13. Koorts & 10 & 7 & 9 & 9 & 35 & 1,51 \\
14. Mensesklachten & 5 & 10 & 13 & 5 & 33 & 1,45 \\
15. Diarmee & 7 & 7 & 14 & 7 & 35 & 1,40 \\
16. Oorsuizen & 7 & 8 & 10 & 10 & 35 & 1,34 \\
17. Buikkrampen & 3 & 14 & 9 & 9 & 35 & 1,31 \\
18. Pijn in rug & 1 & 12 & 19 & 3 & 35 & 1,31 \\
19. Visusklachten & 6 & 9 & 8 & 11 & 34 & 1,29 \\
20. Neusbloeding & 8 & 7 & 7 & 13 & 35 & 1,29 \\
& & & & & &
\end{tabular}




\begin{tabular}{lrrrrrrr}
\hline & 3 & 2 & 1 & 0 & Totad & $\begin{array}{r}\text { Germid } \\
\text { deld }\end{array}$ \\
\hline \hline 21. & Duizeligheid & 3 & 13 & 9 & 10 & 35 & 1,26 \\
22. Misselijkheid & 4 & 8 & 16 & 7 & 35 & 1,26 \\
23. Pijn in de lendenen & 2 & 11 & 13 & 9 & 35 & 1,17 \\
24. Fertiliteitsproblemen & 4 & 8 & 8 & 12 & 32 & 1,13 \\
25. Beklemd gevoel & 2 & 9 & 15 & 9 & 35 & 1,11 \\
26. Obstipatie & 1 & 11 & 12 & 11 & 35 & 1,06 \\
27. Hoesten & 6 & 5 & 9 & 15 & 35 & 1,06 \\
28. Keelpijn & 6 & 4 & 11 & 14 & 35 & 1,06 \\
29. Uitslag & 4 & 8 & 8 & 15 & 35 & 1.03 \\
30. Moeheid & 1 & 9 & 15 & 10 & 35 & 1,03 \\
31. Hoofdptjn & 1 & 8 & 16 & 10 & 35 & 1,00 \\
32. Verstopte neus & 4 & 7 & 7 & 17 & 35 & 0,94 \\
33. Nervositas & 1 & 7 & 15 & 12 & 35 & 0,91 \\
34. Spierpijn & 3 & 5 & 10 & 17 & 35 & 0,83 \\
35. Te dik & 1 & 4 & 17 & 13 & 35 & 0,80 \\
36. Jeuk & 1 & 6 & 12 & 16 & 35 & 0,77 \\
37. Slapeloosheid & 1 & 5 & 13 & 16 & 35 & 0,74 \\
38. Anticonceptieproblemen & 3 & 2 & 10 & 20 & 35 & 0,66 \\
39. Transpireren & - & 5 & 12 & 18 & 35 & 0,63 \\
40. Eerste pilconsult & 3 & 1 & 8 & 23 & 35 & 0,54 \\
& & & & & & & \\
\hline
\end{tabular}

Bestudering van de resultaten leidde tot twee zich opdringende conclusies:

a. De individuele verscheidenheid in beantwoording was zeer groot. Slechts in twee gevallen gaven meer dan 20 van de 35 respondenten hetzelfde antwoord.

b. Ondanks deze verscheidenheid ontstond een zeer duidelijke rangorde van klachten, met gemiddelden variërend van 2,3 tot 0,5 . Bovendien had deze rangorde een grote face-validity. Men hoefde slechts de eerste tien naast de latste tien klachten te zetten om over-" tuigd te zijn van hun verschil in ,ernstklasse".

Op deze wijze werd een rangorde van klachten verkregen al naar gelang de geschatte ernst.

$\mathrm{Er}$ is alle reden om te veronderstellen dat kenmerken van de arts en de praktijk eveneens samenhang vertonen met de uitstelduur. In de literatuur staat hierover weinig beschreven. CASSEE 1973, kon tussen het gedrag van de huisarts en de uitstelduur geen verband vaststellen. Hoewel verschillen in praktijkvoering het morbiditeitspatroon kunnen 
beinvloeden en de uitstelduur per praktijk kan doen verschillen, wordt dit onderzoek beperkt tot duidelijk waarneembare kenmerken van de arts en diens praktijk, zoals het al of niet bestaan van een samenwerkingsverband, de spreekuurworm, de praktijkgrootte, en de leeftijd van de arts. In hoeverre vertonen deze kenmerken samenhang met de uitstelduur? Zo zou men ten aanzien van de leeftijd van de arts kunnen stellen dat, behalve dat menige praktijkpopulatie veroudert met het ouder worden van de huisarts en daardoor al langer zal uitstellen, in het algemeen de patiënten met een oudere huisarts meer consideratie zullen hebben. Vooral bij nachtelijke ,spoedgevallen' zal de patiënt een oudere huisarts niet zo vlug willen, storen'. Dit leidt tot de veronderstelling dat patiënten van oudere huisartsen een langere uitstelduur vertonen.

Over een eventueel bestaande samenhang tussen uitstelduur en spreekuurvorm, samenwerkingsverband of praktijkgrootte, is nog weinig bekend. Daarom en gegeven het feit dat deze kenmerken de laatste tijd. nogal ter discussie staan, is onderzoek hieromtrent m.i. van belang. Een beperking van dit onderzoek is ongetwijfeld dat de onderzoekpopulatie uitsluitend bestaat uit mensen, die besloten hebben de dokter uiteindelijk toch te raadplegen. Patiënten, die als het ware oneindig uitstellen en dus de dokter niet raadplegen, komen in dit onderzoek niet voor.

Bestudering van literatuur en reflectie op mijn eigen ervaringen als huisarts, leidden uiteindelijk tot formulering van de volgende hypothesen.

\subsubsection{HYPOTHESEN BETREFFENDE EIGENSCHAPPEN VAN DE PATTENT}

HYP. I. Vrouwen stellen langer uit dan mannen*).

CASSEE 1973 pag. 107-108. Vrouwen stellen het naar de dokter gaan langer uit. Vrouwen gaven in een onderzoek, gehouden in Utrecht, als reden van hun uitstel vooral aan dat er niemand was die voor hen zorgde als zij ziek waren. Moeders van grote gezinnen, en in het bijzonder met kleine kinderen, hebben een geringere mogelijkheid om naar de huisarts te gaan. Het lijkt plausibel dat zij om deze reden de gang naar de arts zo lang mogelijk uitstellen. Huisvrouwen die ziek te bed liggen, geen

*) Met ,uitstellen" wordt bedoeld, dat men enige tijd laat verlopen tussen het bemerken van de symptomen van een klacht en het besluit de arts te gaan raadplegen; in deze zin is dus bij jeder consult sprake van ,uitstellen'. 
uitkering ontvangen en niet beschikken over huishoudelijke hulp, vormen een kwetsbare groep, waardoor zij geneigd zullen zijn langer uit te stellen. In het Groningse onderzoek van JESSEN bleek, onder specificatie van de variabele ,opleiding', dat alleen vrouwen met een lagere opleiding langer uitstelden dan mannen met een lagere opleiding. In de hogere opleidingsgroepen was geen verschil in witstelduur tussen mannen en vrouwen te constateren. Waarschijnlijk omdat bij hen het al of niet krijgen van een uitkering een minder grote rol speelt, of omdat zij over meer mogelijkheden beschikken om een oplossing voor het probleem te vinden. Daarnaast hebben vooral oudere vrouwen doorgaans een lagere opleiding dan mannen, en een lagere opleiding blijkt gepaard te gaan met een langere uitstelduur. Toetsing van de hypothese vond plaats door van beide geslachten de uitstelduur te bepalen. Bij deze toetsing werd rekening gehouden met leeftijd en opleiding van de patiënt, en met de aard van de klacht.

HYP. II. Patiënten op oudere leeftijd stellen langer uit dan patiënten op jongere leeftijd.

JESSEN 1.974 pag. $39-40$, zegt: ,Ouderen blijken langer uit te stellen dan jongeren. Dit verband met leeftijd geldt zowel voor mannen als vrouwen. Een verklaring hiervoor kan zijn dat oudere mensen over het algemeen minder acute klachten en dus een grote mate van beslissingsvrijheid hebben". Oudere patiënten hebben doorgaans ook meer ervaring met de klacht. Door deze grotere ervaring kunnen ze, bij opnieuw optreden van hun klachten, de mening toegedaan zijn dat van de arts op zulke momenten ook minder te verwachten is. Soms kan zich een zeker fatalisme, een zekere berusting van hen meester maken, waardoor ze geneigd zijn langer te blijven uitstellen.

Toetsing van de hypothese vond plaats door zowel van de oudere als van de jongere patiënten de uitstelduur te bepalen. Bij deze toetsing werd rekening gehouden met geslacht en opleiding van de patiënt, en met de aard van de klacht.

HYP. III. Patiënten met lagere opleidingen stellen langer uit dan patiënten met hogere opleidingen.

In Medische Consumptie concludeerde JESSEN 1974, dat bij de uitsplitsing van de variabele, opleiding', bij mensen met hogere opleidingen geen verband bestond tussen leeftijd. en geslacht enerzijds en uitstelduur anderzijds. Bij mensen met lagere opleidingen bleek deze relatie wel te 
bestaan, waarbij ouderen in vergelijking met jongeren, en vrouwen in vergelijking met mannen, langer uitstelden. Een mogelijke verklaring voor de invloed die de opleiding kennelijk op de uitstelduur heeft, zou kunnen zijn dat mensen met hogere opleidingen een grotere kennis van ziekte hebben, en daardoor meer adequaat de hulp van de arts inroepen. Bovendien worden mensen met lagere opleildingen veelal meer beïnvloed door een traditioneel-magische ziektebenadering. Onder traditioneelmagisch verstaan we een mengeling van magisch-religieuze opvattingen, angsten en traditionele wijsheden, zoals deze in de volksgeneeskunde van de vorige eeuw overheersend waren in onze bevolking (CASse 1973 ). Men kan veronderstellen dat mensen met een meer traditioneel-magische ziektebenadering, bij waarneming van symptomen, duidend op ziekte, meer met angst zullen reageren dan mensen met een meer modernwetenschappelijke ziektebenadering. $\mathrm{Zij}$ hebben minder kennis en voelen zich meer bedreigd door ziekte. Dit onbehagen kan er toe leiden dat men in eerste instantie doet of er niets aan de hand is. $\mathrm{Zij}$ zullen eerder emotioneel reageren, door ontkenning of vluchtreacties, met als gevolg dat men het raadplegen van de arts gaat uitstellen; de $\mathrm{zgn}$. avoidanceescape reactie, vgl. Kosa en ROBERTSON 1969.

Toetsing van de hypothese vond plaats door zowel van patiënten met hogere als lagere opleidingen de uitstelduur te bepalen. Bij deze toetsing werd rekening gehouden met leeftijd en geslacht van de patiënt, en met de aard van de klacht.

HYP. IV. Patiënten die hun huisarts frequent consulteren, vertonen geen verschil in uitstelduur ten opzichte van patiënten, die hun huisarts minder frequent consulteren.

In de literatuur is nauwelijks iets te vinden over de relatie tussen frequentie huisartsenbezoek en uitstelduur. JESSEN 1974, stelt in Medische Consumptie pag. 33, dat er geen significant verband aan te tonen is tussen frequentie huisartsenbezoek en uitstelduur. Enerzijds kan men veronderstellen dat patiënten met lagere opleidingen een ongedifferentieerde behoefte hebben aan hulp, waardoor zij vaker bij de huisarts komen. Ook kunnen patiënten, die de huisarts voor periodieke controles frequent consulteren b.v. tensiecontroles, en daardoor bovendien een ,lagere drempel" tot de arts hebben, de huisarts tijdens deze controles, zo nodig, raadplegen. Dit kan leiden tot een kortere uitstelduur bij deze patiènten. Anderzijds kan men ook veronderstellen dat patiënten, die hun huisarts al vaak zonder resultaat voor een bepaalde klacht hebben 
bezocht, hun andere klachten maar op de koop toe nemen en hiervoor blijven uitstellen.

Sommige overwegingen doen dus een positieve samenhang tussen frequentie huisartsenbezoek en uitstelduur vermoeden, terwijl andere juist pleiten voor een negatieve samenhang.

Daarom werd deze hypothese tweezijdig getoetst, door te bepalen of er een positieve, dan wel negatieve samenhang bestaat tussen frequentie huisartsenbezoek en uitstelduur. Bij deze toetsing werd rekening gehouden met leeftijd, geslacht en opleiding van de patiënt, en met de aard van de klacht.

HYP. V. Patiënten in plattelandspraktijken stellen langer uit dan patiënten in stadspraktijken.

Uit onderzoekingen van Forsyth en Logan 1964, en Pflanz 1969, bleek dat de bevolking in agrarische streken een minder hoge medische consumptie had dan in steden. De afstanden tot het praktijkgebouw zijn op het platteland veelal groter dan in de stad. Weliswaar is de situatie in Engeland anders dan in Nederland, en zijn de praktijkafstanden op het platteland daar in het algemeen groter dan in ons land, toch wil dat niet zeggen dat ook in ons land patiënten op het platteland langer zullen uitstellen. In veel studies ten aanzien van de medische consumptie bleek de afstand tot de dichtstbijzijnde voorziening een roll te spelen. Een minder hoge medische consumptie zegt slechts ten dele wat over het uitstellen. Het kan ook zijn dat mensen op het platteland minder klachten hebben.

Het verschil in socialle status tussen de gemiddelde patiënt en de arts, is op het platteland groter dan in de stad. Dit verschil werkt drempelverhogend, en hangt mogelijk positief samen met een langer uitstel.

Toetsing van de hypothese vond plaats door zowel van patiënten in stads- als in plattelandspraktijken de uitstelduur te bepalen. Bij deze toetsing werd rekening gehouden met leeftijd, geslacht en opleiding van de patiënt, en met de aard van de klacht.

HYP. VI. Patiënten die meer ervaring hebben met de klacht, in die zin dat zij de klacht al eerder hebben gehad eventueel daarvoor zijn behandeld, zullen bij ernstige klachten korter en bij minder ernstige klachten langer uitstellen.

Onder ervaring met een klacht kan men verstaan de ervaring die de patiënt zelf heeft met de klacht, maar ook de ervaring die zijn familie en 
vrienden hebben met de klacht. In ons onderzoek richten we ons op de ervaringen die de patiënten zelf met de klachten hebben gehad. Als de patiènt de klacht al eens eerder heeft gehad, ontstaat er als regel een zekere vertrouwdheid met die klacht. Dit meer vertrouwd zijn met de klacht geeft enige richtlijn, hoe men met zo'n klacht dient om te gaan. Bij opnieuw optreden van cle verschijnselen kan dit leiden tot meer adequaar reageren. Deze gedachtengang leidt tot de veronderstelling dat patiênten, die ervaring hebben met de klacht, bij ernstige klachten niet lang zullen uitstellen, en bij minder ernstige klachten niet onnodig vlug de hulp van de arts zullen inroepen.

Toetsing van de hypothese vond plaats door de klachten te verdelen in ernstige en minder ernstige klachten, en beide groepen weer onder te verdelen al naar gelang de patiënt ervaring heeft met de klacht. Van deze vier groepen werd de uitstelduur bepaald. Bij deze toetsing werd rekening gehouden met leeftijd, geslacht en opleiding van de patiënt.

1.2.2.

HYPOTHESEN BETREFFENDE EIGENSCHAPPEN VAN DE KLACHT

HYP. VII. Bij klachten, die algemeen bekend staan als mogelijke aanwijzingen voor een ernstige ziekte, stellen patiënten korter uit.

Klachten die algemeen bekend staan als mogelijke aanwijzingen voor belangrijke lichamelijke afwijkingen, behoeven niet identiek te zijn met klachten die door de patiënt subjectief als ernstig worden ervaren. De ene patiënt zal bepaalde symptomen als ernstig ervaren, terwijl een andere patiënt dezelfde symptomen als minder ernstig zal duiden. Op pagina 18 staat beschreven hoe Philipsen een ordening verkreeg van de ernst van de onderzochte klachten. Te verwachten valt dat de patiënt langer zal uitstellen naarmate de klachten minder ernstig zijn, of als minder ernstig ervaren worden. RoSENSTOCK 1966, heeft de gedachtengang nader uitgewerkt dat mensen eerder geneigd zijn tot handelen op het gebied van ziekte en gezondheid, naarmate zij ziekte als ernstiger ervaren. Cassee 1973, constateerde tussen de ernst-perceptie en de opleiding een samenhang in die zin, dat naarmate de patiënt minder opleiding heeft genoten, hij een bepaalde klacht vlugger als ernstig beschouwt.

Toetsing van de hypothese vond plaats door van de ernstige en minder ernstige klachten de uitstelduur te bepalen. Bij deze toetsing werd rekening gehouden met leeftijd, geslacht en opleiding van de patiënt. 
HYP. VIII. Büj klachtenpatronen mèt pijn vertoont de patient een kortere uitstelduur dan bï overeenkomstige klachtenpatronen zònder pijn.

Brouwer en TOUW-OTTEN 1974, vonden uit een onderzoek in 3 huisartsenpraktijken dat pijn een grote rol speelt bij de vraag of men de hulp van de arts zal inroepen.

SuCHMANN 1965, vond dat bij ernstige ziektes, pijn in twee van de drie gevallen het voornaamste symptoom was.

Pijn wordt lang niet altijd ervaren als een maatstaf voor de ernst van een klacht. Pijn is echter wel hinderlijk en men will er zo gauw mogelijk van af.

Toetsing van de hypothese vond plaats door van klachten mèt en zònder pijn de uitstelduur te bepalen. Bij deze toetsing werd rekening gehouden met leeftijd, geslacht en opleiding van de patiënt, en met de aard van de klacht.

HYP. IX. Bij klachten, ten aanzien waarvan het psychische aspect overheerst, zullen de patiënten langer uitstellen.

Men kan veronderstellen dat patiënten met psychische klachten vaak een zekere depressiviteit vertonen. Een bepaald fatalisme kan aanwezig zijn. Ten gevolge van zijn depressiviteit kan de patiënt nergens vertrouwen in hebben, ook niet in de arts. Daarom is het denkbaar dat deze patiënten het raadplegen van de arts langer uitstellen.

Een andere veronderstelling is dat de arts, in de ogen van patiënten, aan psychische klachten als regel minder kan doen. Daar komt bij dat diverse patiënten het gevoel hebben, dat psychische klachten bij de arts minder welkom zijn dan somatische klachten. Men meent dan dat men alleen als ziek wordt beschouwd bij somatische klachten.

Toetsing van de hypothese vond plaats door zowel van de overwegend somatische als psychische klachten de uitstelduur vast te stellen. Bij deze toetsing werd rekening gehouden met leeftijd, geslacht en opleiding van de patiënt, en met de aard van de klacht.

\subsubsection{HYPOTHESEN BETREFFENDE EIGENSCHAPPEN VAN DE} HUISARTS EN ZIJN PRAKTIJK

HYP. X. Bij huisartsen die in hun praktijk relatief meer klachten als psychisch aangeven, stellen patiënten langer wit dan bij huisartsen die dit in mindere mate doen. 
Het is denkbaar dat huisartsen, die in hun praktijk veel klachten als psychisch beschouwen, hun patiënten vaak te verstaan geven dat hun klacht ,eigenlijk niets is'. Ze kunnen hun patiënten dan het gevoel geven dat zij onnodig gekomen zijn. Daardoor kan bij de patiënten een zekere terughoudendheid ontstaan, waardoor zij bij nieuwe klachten langer gaan uitstellen. De arts zou hun klachten opnieuw als psychisch kunnen bestempelen.

Persoonlijke kenmerken van de arts kunnen hierbij een rol spelen. De ene arts zal nu eenmaal een klacht vlugger als overwegend psychisch beschouwen dan de andere arts.

Toetsing van de hypothese vond plaats door de uitstelduur te bepalen van patiënten bij huisartsen met relatief veel resp. weinig psychische klachten in hun praktijk. Bij deze toetsing werd rekening gehouden met leeftijd, geslacht en opleiding van de patiënt, en met de aard van de klacht.

HYP. XI. In associatiepraktijken stellen patiënten langer uit dan in solopraktijken.

Schaalvergroting kan als een bedreiging voor de arts-patiënt relatie worden ervaren. Ten aanzien van deze schaalvergroting worden begrippen als massaliteit en verzakelijking veelvuldig gehoord. Soms weten de patiënten van tevoren niet welke huisarts ze krijgen, omdat in associatiepraktijken vaak zeer intensief onderling wordt waargenomen. Indien de patiënt weet dat hij zijn eigen huisarts niet kan raadplegen, zal hij vlugger geneigd zijn langer uit te stellen.

Toetsing van de hypothese vond plaats door vam patiënten in solo- en associatiepraktijken de uitstelduur vast te stellen. Bij deze toetsing werd rekening gehouden met leeftijd, geslacht en opleiding van de patiënt, en met de aard van de klacht.

HYP. XII. In praktijken met, uitsluitend' afspraakspreekuur stellen patiënten langer uit dan in praktijken met, uitsluitend' vrij spreekuur.

Evenals bij afspraakspreekuren bijna altijd de mogelijkheid bestaat om de arts ook te spreken zonder een afspraak te maken, bestaat bij vrije spreekuren meestal ook de mogelijkheid om zo nodig op afspraak te komen. We moeten ons dus ervan bewust zijn, dat een exclusieve spreekuurvorm, in de zin van ,uitsluitend op afspraak' of ,uitsluitend vrij spreekuur' vrijwel niet bestaat. In de hypothese willen we dan ook met , uitsluitend' aangeven, dat de oorspronkelijke spreekuurvorm zoveel mogelijk wordt 
gehandhaafd. De wetenschap, dat men bij afspraakspreekuren niet meteen bij de huisarts terecht kan, zou voor de patiënt een rem kunnen betekenen waardoor hij langer gaat uitstellen. Omdat hij op het moment dat hij de arts zou willen consulteren toch nog eerst een afspraak moet maken, kan de patiënt geneigd zijn het zelf nog een poosje aan te zien. Toetsing van de hypothese vond plaats door van patiënten in praktijken met vrije- c.q. afspraakspreekuren de uitstelduur te bepalen. Bij deze toetsing werd rekening gehouden met leeftijd, geslacht en opleiding van de patiënt, en met de aard van de klacht.

HYP. XIII. In grotere praktijken stellen patiënten langer uit dan in kleinere praktijken.

In grotere praktijken zal de huisarts in het algemeen minder tijd per patiënt hebben dan in kleinere praktijken. Een verzakelijking in de artspatiënt relatie kan hiervan een gevolg zijn. De patiënt zou dan bij nieuwe klachten kunnen denken dat de huisarts toch geen tijd voor hem heeft, en daardoor langer gaan uitstellen. Dit zou vooral het geval kunnen zijn bij klachten van psychische en chronische aard, omdat hierbij de noodzaak tot consultatie vaak nog niet zo groot is. Bij spoedgevallen en ernstige somatische aandoeningen is de vrijheid tot uitstellen duidelijk geringer.

Toetsing van de hypothese vond plaats door van patiënten in grotere en kleinere praktijken de uitstelduur te bepalen. Bij deze toetsing werd rekening gehouden met leeftijd, geslacht en opleiding van de patiënt, en met de aard van de klacht.

HYP. XIV. Bij oudere huisartsen stellen patiënten langer uit dan bij jongere huisartsen.

Het is denkbaar dat tussen oudere huisartsen en de gemiddelde patiënt een groter status-verschil bestaat, dan tussen jongere huisartsen en de gemiddelde patiënt. Een groter status-verschil kan tot een ,hogere drempel' leiden, waardoor de patiënten langer kunnen uitstellen. Ook is het denkbaar dat patiënten met oudere huisartsen meer consideratie hebben dan met jongere huisartsen. Vooral bij minder ernstige klachten kan de patiënt geneigd zijn een oudere huisarts niet zo vlug ,lastig te vallen'. Toetsing van de hypothese vond plaats door van patiënten in praktijken bij oudere en jongere huisartsen de uitstelduur te bepalen. Bij deze toetsing werd rekening gehouden met leeftijd, geslacht en opleiding van de patiënt, en met de aard van de klacht. 


\section{Opzet en uitvoering van het onderzoek}

\subsection{INLEIDING}

De huisarts is de meest aangewezen persoon om de uitstelduur vast te stellen. Op het moment dat de patiënt de huisarts raadpleegt, dus op het consultmoment, kan het best de uitstelduur worden vastgesteld. Geeft de huisarts de uitstelduur tijdens of meteen na het consult weer, dan bestaat de kleinst mogelijke kans op een vertekend beeld. Dit houdt in dat de huisarts de vragenlijsten tijdens het spreekuur moet invullen. Wil de huisarts voldoende gemotiveerd blijven dan zal de belasting voor zijn spreekuur niet te groot mogen zijn. Daarom mogen de vragenlijsten niet te lang zijn.

In onderstaande paragraaf wordt de opzet van het onderzoek besproken, waarbij vooral de samenstelling van de vragenlijst en de deelname aan het onderzoek worden behandeld. In de daaropvolgende paragraaf zal de uitvoering van het onderzoek worden besproken, waarna tenslotte een beschrijving van de onderzochte variabelen in relatie tot de hypothesen volgt.

\subsection{OPZET VAN HET ONDERZOEK}

Zoals in de inleiding werd vermeld, moesten de vragenlijsten goed hanteerbaar en snel in te vullen zijn. Daarom werd gekozen voor het multiple-choice-systeem, waarbij de arts door aankruisen op een gestandaardiseerde vragenlijst, de antwoorden gemakkelijk en vlug kon registreren. Omdat de vragenlijst zo kort mogelijk moest zijn, werd de lijst met mogelijke variabelen beperkt gehouden. Alleen die variabelen die direct vastgesteld konden worden, werden in de vragenlijst opgenomen. Daarnaast werd toch de mogelijkheid opengehouden, belangrijke ter zake doende informatie op de vragenlijsten mede te delen.

De vragenlijst moest gegevens bevatten over de uitstelduur, over de klacht en over de patiënt. De gegevens over de huisarts en diens praktijk werden verkregen door middel van interviews met de aan het onderzoek deelnemende huisartsen. 
Allereerst werd met behulp van een voorlopige vragenlijst in mijn praktijk een proefstudie gehouden, waarbij de hanteerbaarheid van de lijst en de belasting voor zowel de patiënt als de arts, door mij werden onderzocht. Daarna volgde een pilot-study bij alle deelnemende huisartsen (zie volgende paragraaf). Tenslotte werd de definitieve vragenlijst, in een handzamer formaat, samengesteld (zie bijlage I).

Teneinde de betrouwbaarheid van de gebruikte onderzoektechnieken te vergroten en de kans op systematisch optredende verschillen tussen de vragenlijsten te verkleinen, werden de vragen zoveel mogelijk in gesloten vorm gesteld.

Opdat de scores niet door de aard van de hypothesen zouden worden beïnvloed, werden de deelnemende huisartsen onkundig gelaten over de betreffende de uitstelduur geformuleerde hypothesen.

Intussen werd bij de keuze van de deelnemende praktijken gestreefd naar een redelijke spreiding van de huisartsen. Hierbij werd uitgegaan van de contacten die reeds met verschillende huisartsen bestonden. Het onderzoek vond plaats in Zuid-Limburg, meer speciaal in en rondom de stad Maastricht.

Een probleem hierbij was, dat op het moment van onderzoek, in deze regio slechts één enkele groepspraktijk resp. slechts één gezondheidscentrum beschikbaar was. Daarom werden alleen associaties en solopraktijken in het onderzoek betrokken.

\section{Deelname onderzoek:}

\begin{tabular}{lccl}
\hline & Stad & $\begin{array}{l}\text { (Verstedelijkt) } \\
\text { Platteland }\end{array}$ & Totaal \\
\hline Aantal inwoners & $120.000 \mathrm{inw}$. & $55.000 \mathrm{inw}$. & $175.000 \mathrm{inw}$. \\
Uitgenodigd waren & 15 artsen & 15 artsen & 30 artsen \\
$\begin{array}{l}\text { Volledig meegedaan } \\
\text { Gedeeltelijk meegedaan }\end{array}$ & 9 artsen & 11 artsen & 20 artsen \\
(Gezondheidsredenen) & 1 arts & 1 arts & 2 artsen \\
Niet meegedaan*) & 5 artsen & 3 artsen & 8 artsen \\
Bij onderzoek betrokken & $\pm 30.000 \mathrm{inw}$. & $\pm 38.000 \mathrm{inw}$. & $\pm 68.000 \mathrm{inw}$. \\
\hline
\end{tabular}

*) Een van de huisartsen heeft zijn onderzoek voor slechts de helft kunnen voltooien. Omdat zijn gegevens bovendien valk onvolledig waren, werden zij voor het verdere onderzoek niet gebruikt. Twee artsen konden niet deelnemen wegens het verrichten van een eigen onderzoek, een arts was wegens ziekte verhinderd en vier artsen om persoonlijke redenen. 
Op het platteland was drie-vierde deel van het totaal aantal inwoners bij het onderzoek betrokken, en in de stad een-vierde deel.

Een tweede moeilijkheid die zich voordeed was, dat bij de verschillende praktijken de te onderzoeken kenmerken van de arts en de praktijk minder variatie vertoonden, dan men uit onderzoeksoogpunt zou wensen. Onderzoeken wij bijvoorbeeld het samenwerkingsverband bij associaties en solopraktijken op verschil in uitstelduur, dan moet ervoor zorggedragen worden dat de andere kenmerken van de arts en zijn praktijk, zoals spreekuurworm: praktijkgrootte en leeftijd arts, gelijkelijk verdeeld zijn over de beide te onderzoeken praktijkvormen.

Gelukkig bleek het merendeel van de artsen die gevraagd werden, bereid te zijn aan het onderzoek deel te nemen. Uitvallen van velen zou een voldoende spreiding van de verschillende variabelen nadelig hebben kunnen beïnvloeden.

Alle deelnemende huisartsen waren op het moment van onderzoek langer dan 1 jaar in hun praktijk werkzaam.

Het onderzoek vond plaats gedurende de eerste 4 weken van september 1975. De maand september was op de eerste plaats gekozen, omdat in deze maand seizoensinvloeden minder frequent voorkomen dan anders. Gedurende de winter zouden griep en verkoudheden het klachtenpatroon te sterk kunnen beïnvloeden. In de zomermaanden zijn in deze regio bovendien veel praktijken overbelast tengevolge van het toerisme, waardoor de animo om op dat moment aan dit onderzoek deel te nemen naar alle waarschijnlijkheid geringer zou zijn. Op de tweede plaats zijn in de maand september de meeste huisartsen terug van hun zomervakanties. Om praktische redenen was het onmogelijk een zeer groot aantal patiënten te ondervragen. Dit zou te belastend worden voor de deelnemende huisartsen, met het risico dat deelname aan het onderzoek voortijdig zou worden beëindigd. Daarom hebben we ons beperkingen moeten opleggen. Gekozen werd voor een werkwijze, waarbij gedurende 20 werkdagen 5 patiënten per dag werden ondervraagd. Op deze wijze zouden alle deelnemende huisartsen 100 vragenlijsten invullen.

$\mathrm{Na}$ beëindiging van de steekproef werd de datamatrix opgesteld. Daarna vond de ponsing plaats, waarna steekproefsgewijs een controleponsing werd uitgevoerd. Tenslotte werden van alle variabelen frequentietabellen samengesteld, waarbij het aantal blanco's en de scoring per categorie werd gecontroleerd. Waar nodig vond een reductie plaats door samentrekking van enkele categorieën; zie pag. 48. Na deze zuivering van het materiaal werd een aanvang gemaakt met de analyse. 


\subsection{UITVOERING VAN HET ONDERZOEK}

Een pilot-study werd gehouden bij alle huisartsen die hadden toegezegd. Hierbij werden tien willekeurig gekozen patiënten ondervraagd. Alle deelnemers konden op deze wijze inspelen op de vragenlijst. Knelpunten werden opgespoord, en waar nodig verbeteringen aangebracht. Op deze wijze kregen de huisartsen een voorproefje van wat hen te wachten stond. Vijf patiënten per dag ondervragen bleek geen tè zware belasting te zijn voor de deelnemende huisartsen. Groter was de vraag of alle huisartsen dit vier weken zouden volhouden. Misschien was een steekproef van tien patiënten per dag, gedurende tien dagen te prefereren geweest, echter door voor het onderzoek een ruimere spreiding in de tijd te nemen, werd waarschijnlijk een gelijkmatiger verdeling van de klachten verkregen. Zou het onderzoek in een kortere tijdsperiode hebben plaatsgevonden, dan zouden weersinvloeden of kleinere epidemieën storend hebben kunnen werken.

Als belangrijkste knelpunt kwam naar voren het aselect kiezen van de patiënten. Ter voorkoming van eigen selectie werden tijdens het eigenlijke onderzoek de patiënten gekozen volgens een bepaalde rangorde, waarbij tijdens het spreekuur steeds de $3 \mathrm{e}, 6 \mathrm{e}, 11 \mathrm{e}, 16 \mathrm{e}$ en $21 \mathrm{e}$ patiënt werden ondervraagd, indien zij kwamen met een ,nieuwe klacht'.

Onder een nieuwe klacht verstaan we een klacht, waarvoor de patiënt gedurende de voorafgaande twaalf maanden de huisarts niet heeft geraadpleegd. Dus alleen consulten werden geteld en geen verrichtingen zoals een kuur allergie-injecties.

Kwam in bovenstaande rangorde een patiënt voor die geen nieuwe klacht had, dan werd de eerstvolgende patiënt genomen. Bij een onvoldoend aantal patiënten op het spreekuur werd het onderzoek tijdens de visites voortgezet, te beginnen bij het eerste huisbezoek.

De eerste twee patiënten tijdens het spreekuur werden niet ondervraagd, omdat bij hen in het algemeen meer spoedgevallen aanwezig zijn.

Voor aanvang van het eigenlijke onderzoek, kregen alle deelnemende huisartsen honderd vragenlijsten gezonden, te zamen met een schriftelijke en mondelinge toelichting waarbij opzet en uitwoering van het onderzoek nog eens duidelijk werden uiteengezet.

De eerste maandag van september 1975 werd met het onderzoek begonnen, waarna gedurende vier weken elke werkdag vijf patiënten werden ondervraagd. $\mathrm{Na}$ de eerste week werd met alle deelnemende huisartsen contact opgenomen, om waar nodig problemen te helpen oplossen. 
Ongetwijfeld hebben ook de oplettendheid en stimulans van de praktijkassistentes bevorderd, dat de vragenlijsten elke dag werden ingevuld. Twee artsen hadden toegezegd maar gingen tijdens bet onderzoek op vakantie. Na hun vakantie hebben zij het onderzoek meteen afgemaakt.

De interviews vonden plaats met alle deelnemende huisartsen, waarbij gegevens over de arts en de praktijkvoering werden vastgelegd. Opwallend hierbij was de grote openhartigheid waarmee de gegevens werden verstrekt. Velen toonden grote belangstelling voor het onderzoek en werkten enthousiast mee.

\subsection{BESCHRIJVING VAN DE VARIABELEN IN RELATIE TOT DE HYPOTHESEN}

Vanzelfsprekend moesten wij ons bij de keuze van de variabelen die van belang geacht kunnen worden voor de verklaring van de uitstelduur van patiënten met nieuwe klachten, beperken tot die zaken waarnaar tijdens het onderzoek was geïnformeerd.

Zowel kwalitatief als kwantitatief moesten wij ons beperkingen opleggen. Van de ene kant kan de arts geen uren zitten praten met de patiënt, en van de andere kant kan men de patiënt ook niet alles vragen. De in het onderzoek gebruikte variabelen moeten dan ook niet gezien worden als de enige, die van belang zijn voor de verklaring van onze afhankelijke variabele; de uitstelduur.

Uit de literatuur (CASSEE 1973 en JESSEN 1974) bleek, dat ten aanzien van kenmerken van de patiënt vooral de basisvariabelen: leeftijd, geslacht en opleiding, van invloed zijn op de uitstelduur. Van deze basisvariabelen kan worden verondersteld dat ze de uitstelduur beïnvloeden, zowel via de consumptiegeneigdheid, als de consumptiemogelijkheid, als de consumptienoodzaak van de patiënt (CASSEE 1973).

Ten aanzien van de klacht werd de uitstelduur steeds bij overeenkomstige klachten vergeleken. Om deze redenen werd de analyse apart uitgevoerd voor de basisvariabelen: leeftijd, geslacht en opleiding van de patiënt, en voor de aard van de klacht. Op deze wijze werd getracht inzicht te krijgen in de invloed die deze variabelen op de uitstelduur hebben.

Ter beoordeling van de motivering om niet langer uit te stellen, werd de patiënt gevraagd naar de, reden van komst naar het spreekuur'. Alle overige variabelen hebben in ons onderzoek betrekking op de door ons gestelde hypothesen. 
In totaal werden gegevens verzameld over zestien variabelen, waarvan de eerste variabele, als afhankelijke variabele, de uitstelduur betrof. Zes variabelen geven inlichtingen over kenmerken van de patiënt. Vijf variabelen verstrekken gegevens over kenmerken van de klacht. En vier variabelen geven inlichtingen over kenmerken van de huisarts en diens praktijk. Aldus komen we tot onderstaand schema:

DE AFHANKELIJKE VARLABELE:

1. De uitstelduur.

DE ONAFHANKELIJKE VARIABELEN:

Patiënt: 2. Geslacht.

3. Leeftijd.

4. Opleiding.

5. Frequentie huisartsenbezoek.

6. Stads- of plattelandspatiënt.

7. Ervaring met de klacht.

Klacht : 8. Aard wan de klacht.

9. Indeling van de klacht naar orgaanstelsel.

10. Ernst van de klacht.

11. Karakter van de klacht wat betreft overwegend psychisch of somatisch.

12. Reden van consultatie.

Huisarts en praktijk: 13. Samenwerkingsverband.

14. Spreekuurvorm.

15. Praktijkgrootte.

16. Leeftijd huisarts.

De opbouw van deze paragraaf is verder als volgt. Eerst wordt, waar nodig, een beschrijving van iedere variabele gegeven. Daarna, zo mogelijk, een literatuurverwijzing. Tenslotte wordt bij iedlere variabele de relatie tot de hypothese(n) aangegeven.

VARIABELE 1. De uitstelduur.

Beschrijving. Onder de uitstelduur wordt in deze studie verstaan de tijdsduur tussen het moment waarop men een gevoel. van onwelzijn resp. 
een ziekteverschijnsel voor het eerst waarneemt, en het moment waarop daarvoor de hulp van de huisarts wordt ingeroepen. De uitstelduur werd weergegeven in dagen en weken. $\mathrm{Zijn}$ tijdsduur werd gemeten door middel van de vraag: "Hoe lang had u de verschijnselen al voor u de dokter raadpleegde?" Bij afspraakspreekuren werd van deze tijdsduur de periode, liggend tussen het moment van aanvraag van het consult en het tijdstip waarop het consult plaatsvond, in mindering gebracht. Duidelijk hierbij is, dat hoe langer een klacht bestaat, hoe minder de tijdsduur, nodig voor het maken van een afspraak (meestal $\pm 1 \mathrm{dag}$ ), van invloed is op de uitstelduur.

De uitstelduur werd als volgt ingedeeld:

$0=$ De patiënt bemerkte de klacht niet langer dan 1 dag voor aanvraag van het consult. Dit is dus de korte uitstelduur.

1 = De patiënt bemerkte de klacht niet langer dan 1 week voor aanvraag van het consult, maar langer dan 1 dag.

2 = De patiënt bemerkte de klacht niet langer dan 3 weken voor aanvraag van het consult, maar langer dan 1 week.

3 = De patiënt bemerkte de klacht langer dan 3 weken voor de aanvraag van het consult. Dit is dus de lange uitstelduur.

\subsubsection{VARLABELEN MET BETREKKING TOT DE PATIENT}

VARIABELE 2. Het geslacht van de patiënt.

Literatuur. ANDERSON 1963, stelde dat het geslacht van de patiënt tot de primaire variabelen behoort, die het gebruik van voorzieningen op het gebied van de gezondheidszorg beïnvloeden. VAN Es 1969 pag. 27, constateerde aanzienlijke verschillen in het ziektepatroon van man en vrouw. Dit verschil in ziektepatroon van man en vrouw leidt bij beide geslachten tot een verschillend klachtenpatroon, met daaraan verbonden een verschillende uitstelduur. JESSEN 1974, stelde in het Groningse onderzoek naar medische consumptie vast, dat bij patiënten met lagere opleidingen vrouwen langer uitstelden dan mannen.

Relatie tot de hypothese. Het geslacht behoort tot de basisvariabelen van de patiënt met zulk een grote invloed op de uitstelduur, dat bij toetsing van de hypothesen rekening gehouden moest worden met dit kenmerk van de patiënt. 
VARIABELE 3. De leefijid van de patient.

Beschrijving. Tijdens het onderzoek werden de leefijden van de patiènten ingedeeld in twee groepen:

Jongere patiënten: $17-45$ jaar.
Oudere patiënten: $\geqslant 46$ jaar.

Patiënten, jonger dan 17 jaar, werden niet in het onderzoek opgenomen, omdat zij niet altijd op eigen initiatief de huisarts raadplegen, maar nogal eens gestuurd worden door hun ouders.

Literatuur. ANDERSON 1963, stelde dat ook de leeftijd van de patiënt tot de primaire variabelen behoort, die het gebruik van voorzieningen op het gebied van de gezondheidszorg beïnvloeden. Evenals GaboureK 1963 pag. 277, Cartwright 1967 pag. 32, Kessel en Shepherd 1965, constateerde hij een positieve relatie tussen de leeftijd van de patiënt en doktersbezoek. Ook CASSEE 1973 en JESSEN 1974, rekenden de leeftijd van de patiënt tot de basisvariabelen, die een speciale invloed hebben op de uitstelduur. Ouderen stellen langer uit. Ouderen hebben meer chronische klachten dan jongeren. Jongeren vertonen meer acute klachten en hebben meer ongevallen dan ouderen. Bij acute klachten is de beslissingsvrijheid tot uitstellen geringer dan bij chronische klachten. Soms kan dan zelfs de mogelijkheid tot beslissen niet meer aanwezig zijn.

Relatie tot de hypothese. De leeftijd van de patiënt heeft, evenals het geslacht, een grote invloed op de uitstelduur. Bij de toetsing van de hypothesen werd dan ook rekening gehouden met de leeftijd van de patiënt.

VARIABELE 4. De opleiding van de patiënt.

Beschrijving. De sociale status van de patiënt wordt in belangrijke mate bepaald door de opleiding van de patiënt. Zeker zullen nog vele andere variabelen, zoals beroep en inkomen, van invloed zijn op de sociale status van de patiënt. Echter bij de door ons gemeten variabelen ten aanzien van de sociale status, bleek alleen de opleiding voldoende gegevens te werstrekken, om enig inzicht te krijgen in de sociale status van de patiënt. Met betrekking tot het beroep gaf een onderscheid in zelfstandig of loondienst onvoldoende informatie over de sociale status. Daarom werd ten aanzien van de sociale status beperkt tot uitsluitend de variabele opleiding. 
Het opleidingsniveau van de patiênt werd ingedeeld in:

$\begin{array}{lll}\text { Lagere opleidingen } & \text { d.w.z. } & \text { 1.b.o. of lager. } \\ \text { Midden opleidingen } & \text { d.w.z. } & \text { m.b.o., mavo t.m. havo. } \\ \text { Hogere opleidingen } & \text { d.w.z. } & \text { h.b.o. of academisch. }\end{array}$

Literatuur. In Medische Consumptie concludeerde JESSEN 1974, dat bij de uitsplitsing van de variabele opleiding, bij mensen met een hogere opleiding geen verband bestond tussen geslacht en uitstelduur. Bij mensen met lagere opleidingen bleek deze relatie wel te bestaan, waarbij vrouwein in vergelijking met mannen langer uitstelden. CASSEE 1973 en JESSEN 1974, hechtten speciale betekenis aan de opleiding, die zij rekenden tot de basisvariabelen van de patiënt.

Relatie tot de hyporhese. Evenals leeftijd en geslacht werd ook de opleiding tot de basisvariabelen van de patiënt gerekend, met een mogelijk grote invloed op de uitstelduur. Bij de toetsing van de hypothesen werd dan ook rekening gehouden met het opleidingsniveau van de patiënt.

VARIABELE 5. Frequentie huisartsenbezoek.

Beschrijving. Deze omvat alle contacten die de huisarts en de patiënt als zodanig, met elkaar hebben gehad gedurende het afgelopen jaar. Dit geldt voor zowel nieuwe klachten als ook voor periodieke controles b.v. tensiecontroles. De vraag naar het aantal patiënt-arts contacten gedurende het afgelopen jaar werd schematisch weergegeven volgens onderstaande tabel.

$$
\begin{aligned}
& \text { Weinig : } \quad 0-3 \text { per jaar. } \\
& \text { Normaal: } 4-6 \text { per jaar. } \\
& \text { Vaak : } \geq 7 \text { per jaar. }
\end{aligned}
$$

Literatuur. CASSEE 1973, stelde dat raadpleging van de arts frequenter zal plaatsvinden, naarmate de consumptienoodzaak, de consumptiegeneigdheid en/of de consumptiemogelijkheid groter is.

Kessel en ShePherd 1965, constateerden dat mensen die zelden of nooit de arts raadplegen, kritischer zijn ten opzichte van de dienstverlening van de arts, zoals wachttijden, voorschrijfpatroon en de mate van informatie die de arts geeft. Een andere belangrijke bevinding was, dat het percentage mensen dat gedurende een jaar de huisarts niet bezoekt, in verschillende streken geen grote verschillen vertoont. LAMBERTs 1974, constateerde dat in een groepspraktijk in Ommoord dit ongeveer $25 \%$ 
was bij elk van de vier huisartsen, zodat hij veronderstelde dat op dit punt weinig zuigende of afstotende werking van de huisartsen uitgaat. VAN DER VeldeN 1971 en VAN DER Ploeg 1976, stelden vast dat neurotische labiele persoonlijkheden meer contact met de huisarts hebben dan stabiele persoonlijkheden.

Relatie tot de hypothese. Hypothese IV onderzoekt de samenhang tussen de frequentie van de patiënt-arts contacten en de uitstelduur.

\section{VARIABELE 6. Stads-of plattelandsbevolking.}

Beschrijving. Hier hebben we eigenlijk te doen met een variabele, waarvan de porté niet helemaal duidelijk is. Enerzijds wonen aan de rand van de stad mensen, die we veelal als plattelandsmensen zouden kunnen bestempelen (b.w. mensen wonend op boerderijen in Amby, Borgharen, Heugem of St.-Pieter), anderzijds zijn vele plattelandsgemeenten al dusdanig werstedelijkt, dat we hier nog moeilijk van het typische ,platteland' kunnen spreken. Veel stedelingen zijn op het platteland gaan wonen. Het platteland werd dan ook alleen gemeten aan de hand van de vestigingsplaats van de huisarts. Praktijken van huisartsen, woonachtig in de steden Maastricht en Heerlen, werden beschouwd als stadspraktijken, en alle deelnemende praktijken daarbuiten als plattelandspraktijken. Op deze wijze werden 12 plattelandspraktijken en 10 stadspraktijken verkregen.

Literatuur. Uit het Britse morbiditeitsonderzoek van LoGAN e.a. bleek dat de grote-stadsbewoners vaker een beroep op hun huisarts doen. Ook een onderzoek van WrLliams in Zuid-Wales toonde aan dat op het platteland minder vaak de hulp van de huisarts werd ingeroepen dan in de steden. Mogelijk spelen hier de grotere afstanden op het platteland een rol. Geldit dit geografische verschil in het inroepen van de hulp van de huisarts ook ten aanzien van de uitstelduur?

Volgens CASSEE 1973 pag. 127, moet er verschil aanwezig zijn tussen het uitstel in de stad en op het platteland.

Uit het proefschrift van WINKLlER-PRINS 1966, bleek dat tussen stad en platteland een verschillend verwachtingspatroon bestaat van de huisarts. Volgens hem verwacht de patiënt op het platteland, meer dan in de stad, dat de huisarts ook adviezen geeft met betrekking tot sociale problemen. Dit zou echter een argument zijn voor een grotere consultfrequentie op het platteland. 
Relatie tot de hypothese. Hypothese $\mathrm{V}$ tracht vast te stellen of in deze regio verschil in uitstelduur bestaat tussen deze beide bevolkingsgroepen.

VARIABELE 7. Ervaring met de klacht.

Beschrijving. Om enig inzicht te krijgen in de ervaring, die de patiënt met de klacht heeft, werd de patiënt allereerst gevraagd of hij de klacht al eens eerder heeft gehad. Dit moet dan wel langer dan 1 jaar geleden zijn, want om van een ,nieuwe klacht' te kunnen spreken was de afspraak gemaakt, dat de patiënt gedurende de voorafgaande twaalf maanden de huisarts voor deze klacht niet mocht hebben geraadpleegd. Op de tweede plaats werd de patiënt gevraagd of hij toen voor deze klacht was behandeld. Meer nog dan bij de eerste vraag geeft deze vraag, bij positieve beantwoording, een vermoedelijke ervaring aan met de klacht.

Relatie tot de hypothese. Hypothese VI stelt dat patiënten die meer ervaring hebben met de klacht een meer adequaat uitstel hebben, in die zin dat zij bij ernstige klachten korter en bij minder ernstige klachten langer uitstellen. Heeft bijvoorbeeld iemand in het verleden ooit een niersteenaanval gehad, dan zal hij bij een recidief de pijn meteen herkennen en weten hoe te handelen.

\subsubsection{VARIABELEN MET BETREKKING TOT DE KLACHT}

Variabele 8. Aard van de klacht.

Beschrijving. Eenenveertig veel voorkomende klachten zijn schematisch samengevoegd. Dit vereenvoudigde de beantwoording, en gaf meer uniformiteit in de weergave van de kllacht. Hoewel de betreffende arts, ten gevolge van dit voorgedrukt schema, enigszins beïnvloed kon worden, voorkwam dit schematisch weergeven van de klachten een al te subjectieve beantwoording door de huisarts. Daarnaast bleef de mogelijkheid bestaan om klachten, die niet in het schema stonden, afzonderlijk te vermelden. Omdat de patiënt meestal met meerdere, vaak met elkaar samenhangende, klachten bij de huisarts komt, werd bij deze variabele de mogelijkheid gegeven zowel de hoofdklacht als de nevenklachten te vermelden. Onder de hoofdklacht werd verstaan de eigenlijke klacht waarvoor de patiënt de arts consulteerde. Dit is dus ,de klacht' die ook bij de statistische analyse wordt gebruikt. Onder de nevenklachten verstaan we de bijkomende klachten die tijdens het consult worden geuit, 
en die ter verduidelijking van het ziektebeeld in de wragenlijst werden opgenomen. Bijvoorbeeld de hoofdklacht ,benauwdheid', met als nevenklachten ,pijn op de borst bij inspanning' en ,dikke enkels", zal duiden op een cardiale aandoening; terwijl de hoofdklacht ,benauwdheid', gepaard gaande met de nevenklachten ,hoesten' en ,koorts', eerder op een aandoening van de luchtwegen zal duiden.

Onderstaande veel voorkomende klachten werden willekeurig gekozen.

Klachten:

Duizeligheid

Hoofdpijn

Koorts

Moeheid

Nervositas

Slapeloosheid

Transpireren

Visusklachten

Keelpijn

Oorpijn

Oorsuizen

Slecht horen

Verstopte neus

Neusbloeding

Hoesten

Benauwdheid

Hartkloppingen

Beklemd gevoel

Pijn op de borst

Dikke enkels

Misselijkheid

\author{
Braken \\ Diarrhee \\ Maagzuur \\ Maagpijn \\ Buikkrampen \\ Obstipatie \\ Te dik \\ Anaalklachten \\ Pijn bij plassen \\ Pijn in de lendenen \\ Mensesklachten \\ Eerste pilconsult \\ Knobbeltje \\ Pijn in de rug \\ Spierpijn \\ Gewrichtspijn \\ Uitslag \\ Jeuk
}

Anticonceptieprobleem

Fertiliteitsprobleem

Omdat een klachtenlijst nooit volledig kan zijn, werd de mogelijkheid open gelaten om klachten die niet op de lijst voorkwamen bij te schrijven. Voor voorbeelden; zie variabele 9.

Relatie tot de hypothese. Ten behoeve van hypothese VI werden de klachten ingedeeld al naar gelang de patiënt ervaring heeft met de klacht, d.w.z. naargelang hij de klacht al eens eerder heeft gehad, eventueel daarvoor is behandeld.

Ten behoeve van hypothese VII werden de klachten ingedeeld al naar gelang de klacht een uiting kan zijn van een ernstige somatische aandoening; zie verslag Philipsen 1978. 
Ten behoeve van hypothese VIII werden de klachten ingedeeld naargelang ze al of niet gepaard gaan met pijn.

Ten behoeve van hypothese IX en $\mathrm{X}$ werden de klachten door de arts ingedeeld naargelang de klacht beschouwd kan worden als overwegend somatisch, psycho-somatisch, psychisch of maatschappelijk van aard. Bij alle owerige hypothesen werden de klachten steeds groepsgewijs vergeleken naar de aard van de klacht.

\section{VARIABELE 9. Indeling van de klacht maar orgaanstelsel.}

Beschrijving. Al naar gelang het orgaanstelsel waarin de klachten voorkwamen werden ze ingedeeld in tien groepen. Deze samenvoeging was noodzakelijk ter verkrijging van voldoende aantallen voor de analyse. Soms werden hiertoe nog enkele klachtengroepen samen genomen, zoals k.n.o.-klachten en klachten van de luchtwegen; gezwellen en huidklachten; en soms algemene klachten, huidklachten en sexualiteitsproblemen. Daar waar deze samenvoegingen plaatsvonden wordt dit steeds duidelijk aangegeven. Uiteraard kan deze indeling nooit helemaal volledig zijn. Zo werden klachten op k.n.o. gebied wel groepsgewijs samen genomen, en bijvoorbeeld klachten op oogheelkundig gebied niet. De reden hiervan is dat klachten op oogheelkundig gebied in de onderzoekpopulatie in te geringe aantallen voorkwamen om hieraan verantwoorde conclusies te verbinden.

Bij onderlinge vergelijking van de uitstelduur van de klachten werd meestal onderstaande indeling gehanteerd.

\section{Indeling:}

1. Algemene klachten

2. K. in.o.-kiachten

3. Klachten van de luchtwegen

4. Hartklachten

5. Buikklachten
6. Urogenitaalklachten

7. Gezwellen

8. KIachten van het bewegingsapparaat

9. Huidklachten

10. Sexualiteitsproblemen

Klachten die niet op de lijst voorkwamen werden per groep bijgeschreven, onder de noemer ,overige klachten'. Op deze wijze werden onderstaande , overige klachten' verkregen met voorbeelden uit de praktijk.

\section{Indeling:}

Overige algemene klachten, b.v. een verlamming (facialisparese).

Overige k.n,o,-klachten, b.y. kaakabces. 
Overige klachten van de luchtwegen komen in onderzoek niet voor.

Overige hartklachten, $b$.w. dooie vingers.

Overige buikklachten, b.w. wormen (oxyuriasis).

Overige urogenitaalkllachten, b.v. vaginat bloedverlies in menopauze.

Overige gezwellen. b.v. een ingetrokken tepel.

Overige klachten van het bewegingsapparaat, $b . v_{*}$ pijn in linker been.

Overige huidklachten, b.w. wratten.

Overige klachten op sexualiteitsgebied, b. $w_{n}$ anorgasmie.

Relatie tot de hypothese. Hypothesen I t.m. V en XI t.m. XIV houden steeds rekening met deze indeling.

VARIABEle 10. De ernst van de klacht.

Beschrijving. Op pagina 18 staat beschreven hoe aan de hand van een rapport van Joosten, Philipsen en VAN REek 1978, een ordening werd verkregen van de klachten, al naar gelang de ernst van de klacht. Door middel van een kwartielindeling van bovenstaande ordening van klachten, verkregen we een indeling van de klachten in 3 groepen, iedler met een verschillende mate van ernst.

\section{Indeling:}

a. Het eerste $1 / 4$ deel van het aantal klachten werd beschouwd als ,meest ernstige klachten'. Dit bleken de onderstaande 11 ,meest ernstige klachten' te zijn.

b. Het volgende $1 / 2$ deel van het aantal klachten werd beschouwd als ,minder ernstige klachten'. Dit bleken de onderstaande 18 ,minder ernstige klachten' te zijn.

c. Het laatste $1 / 4$ deel van het aantal klachten werd beschouwd als ,minst ernstige klachten'. Dit bleken de onderstaande 11 ,minst ernstige klachten' te zijn.

Op deze wijze werden de volgende 3 groepen van klachten verkregen:

11 meest ernstige klachten:

1. Knobbeltje

2. Pijin op de borst

3. Pijn bij plassen

4. Bienauwdheid

5. Gewrichtspijn

6. Dikke enkels
7 Anaalklachten

8. Oorpijn

9. Braken

10. Maagpijn

11. Hartkloppingen 
18 minder ernstige klachten:

1. Slecht horen

2. Koorts

3. Meriseskllachten

4. Diarrhee

5. Oorsuizen

6. Buikkrampien

7. Pijn in de rug

8. Visusklachten

9. Neusbloeding
10. Duizeligheid

11. Misselijkheid

12. Pijn in de lendenen

13. Fertiliteitsprobleem

14. Beklemd gevoel

15. Obstipatie

16. Hoesten

17. Keelpiin

18. Uitsilag

\section{1 minst ernstige klachten:}

1. Moeheid

2. Hoofdpijn

3. Verstopte neus

4. Nervositas

5. Spierpijn

6. Te dik
7. Jeuk

8. Slapeloosheid

9. Anticonceptieprobleem

10. Transpireren

11. Eerste pilconsult

Literatuur. CASSEE 1973, constateerde dat bij uitstellen de noodzaak om de hulp van de arts in te roepen een belangrijke rol speelt. De patiënt stelt langer uit naarmate de klachten minder ernstig zijn, of als minder ernstig ervaren worden. Er is een samenhang te constateren met zowel de subjectieve als de meer objectieve noodzaak om de arts te raadplegen. De samenhang met deze, rechtstreeks met ziekte samenhangende variabelen, is niet zo verwonderlijk. Interessanter is de vraag, welke factoren een rol spelen bij de subjectief ondervonden ernst van de klacht.

Factoren die hierbij een rol kunnen spelen zijn:

a. Allerlei gevoelens als pijn, angst voor blijvende gevolgen, etc.

b. Behalve met de ondervonden hinder van de klacht blijkt ook een samenhang met de gemiddelde dur van de aandoening aanwezig te zijn. Aandoeningen die objectief gezien langer duren, worden als ernstiger beschouwd.

c. Bij de ernst-perceptie is een samenhang te constateren met de opleiding van de patiënt. Hoe minder opleiding, hoe erger men het vindt als men bepaalde klachten krijgt.

Relatie tot de hypothese. Hypothese VII onderzoekt of patiënten bij klachten, die beschouwd worden als uiting van een mogelijk ernstige somatische aandoening, sneller naar hun huisarts gaan dan in het geval dat de klachten niet onder die verdenking staan. 
VARIABELE 11. Het karakter van de klacht, wat betreft overwegend somatisch of psychisch.

Beschrijving. De klachten in dit onderzoek werden door de huisarts beoordeeld als zijnde overwegend somatisch, psycho-somatisch, psychisch of maatschappelijk. Op de betrekkelijkheid van dit oordeel is reeds gewezen, gelet op de uiteenlopende accentuering van de verschillende artsen. Met deze karakterisering van de klacht willen we ook de betekenis en de beleving van de klacht voor de patiënt aangeven, wat weer van invloed is op de uitstelduur.

Literatuur. BLACKWELL 1967, constateerde dat leden van de uppermiddle-class bij psycho-somatische en bij psycho-sociale klachten langer uitstelden dan bij somatische klachten. Een psycho-somatische resp. psycho-sociale aandoening werd beleefd als iets waar men zelf wat aan kan doen. De patiënten trachtten eerst zelf tot een oplossing te komen, en pasten veel zelfmedicatie toe.

VAN Es zegt in zijn boek „Patiënt en huisarts” 1974 pag. 55: „Voor velen is eigenlijk alleen een somatische ziekte aanvaardbaar als reden om een arts te raadplegen. Een psycho-somatische resp. psycho-sociale aandoening wordt vaak beleefd als iets waar men in eerste instantie zelf wat aan kan doen. Daarom zoekt een patiënt ook vaak een rechtvaardiging voor zijn klachten in een somatische diagnose".

Relatie tot de hypothese. Hypothese IX stelt dat patiënten met overwegend somatische klachten in het algemeen een kortere uitstelduur hebben dan patiënten met overwegend psychische klachten. Hypothese $\mathrm{X}$ stelt dat huisartsen, die meer dan het gemiddeld aantal psychische klachten in hun praktijk aangeven, een langere uitstelduur in hun praktijk aantreffen dan huisartsen, die minder dan het gemiddeld aantal psychische klachten in hun praktijk aangeven.

VARIABELE 12. De reden van hulpvragg door de patiënt.

Beschrijving. Onder de reden van hulpvraag wordt verstaan wat de patiënt als belangrijkste probleem c.q. reden ter tafel brengt om de arts te raadplegen. Waarom komt de patiënt nú met déze klacht bij de arts? Waarom wilde de patiënt niet langer uitstellen? Schematisch werden tien veel voorkomende antwoorden samengevoegd, waarbij een onderscheid gemaakt werd tussen fysieke hinder en sociale hinder als reden van hulpvraag. Alhoewel de fysieke hinder en de sociale hinder van 
een aandoening niet strikt van elkaar te scheiden zijn, zal de ene aandoening overwegend fysieke hinder veroorzaken b.v. pijnklachten, en de andere aandoening overwegend sociale hinder veroorzaken b.v. slecht horen, visusklachten.

Indeling reden van hulpvraag:

1. Pijn staat op de voorgrond van de klacht.

2. De klacht is fysiek hinderlijk.

3. De kllacht is sociaal hinderlijk.

4. Patiènt maakt zich ongerust.

5. De klacht is verergerd.

6. De klacht gaat niet spontaan over, of verbetert onvoldoende.

7. Patient is door anderen gestuurd.

8. Patiënt had al ervaring met dergelijke klacht.

9. Patient zou toch op spreekuur komen.

10. Er bestaat werzuimbehoefte.

Alleen de reden verzuimbehoefte wordt door de huisarts aangegeven. Alle andere redenen door de patiënt.

Literatuur. Welke factoren zijn van invloed op de beslissing de arts te consulteren?

Behalve de reeds besproken factoren van de patiënt (zoals leeftijd, geslacht, opleiding en geografische aspecten), en factoren van de klacht (zoals ervaring c.q. kennis, ernst en overwegend somatisch of psychisch karakter), vertonen ook de beleving van de klacht en de invloed van de omgeving samenhang met de uitstelduur.

\section{De beleving van de klacht.}

KOSA en ROBERTSON 1969, stelden dat de beleving van de symptomen bepaald wordt door:

a. Het specifiek onbehagen, ontstaan door de symptomen van de klacht.

b. Daarnaast vormt de verstoring in de gezondheidstoestand een aanknopingspunt voor het in ieder individu aanwezige algemene a-specifieke onbehagen. De mate van dit onbehagen is niet afhankelijk van de ernst van de verstoring. Het totale onbehagen, dat door de verstoring in de gezondheid wordt opgeroepen, is de resultante van deze twee vormen. De grootte ervan hoeft dus niet in verband te staan met de ernst van de klacht. Daardoor is het gedrag van mensen bij ziekte niet zonder meer afleidbaar uit de ernst van de aandoening. 
Brouwer en Touw-OtTen 1974, stelden dat bij een korte uitstelduur angst vaak de doorslaggevende factor tot het inroepen van de hulp van de arts bleek te zijn. Bij een uitstelduur langer dan vier dagen, begon het ,als ongewoon ervaren van het klachtenbeloop' een steeds belangrijkere rol te spelen. Beide d.w.z. angst en het, als ongewoon ervaren van het klachtenbeloop', hangen natuurlijk sterk met elkaar samen.

ZBOROWSKY 1958, stelde vast dat de pijnbeleving cultureel bepaald wordt. Volgens ZoLA 1966, bestaan er bepaalde ,triggers' die aanleiding zijn tot het inroepen van medische hulp. Deze ,triggers' zijn sterk persoonlijk van aard en geven aan de klacht een bepaalde geladenheid, zoals een puistje in het gelaat van een puber.

\section{De invloed van de ongeving.}

Familie, vrienden en kennissen geven vaak gevraagd of ongevraagd advies aan een zieke. FrEIDSON 1970, noemt het proces van overleg met personen uit de directe omgeving het, lay-referral-system'. Voor de huisarts is het van belang inzicht te krijgen in dit ,lay-referral-system' van zijn patiënten.

Volgens CASSEE 1973, wordt het uiteindelijk inroepen van de hulp van de huisarts niet alleen beïnvloed door de ernst, duur en hinder van de symptomen, maar ook door de sociale pressie.

Relatie tot de hypothese. Hypothese VIII stelt dat bij klachten, gepaard gaande met pijn, de hulp van de huisarts vlugger wordt ingeroepen dan bij overeenkomstige klachten zonder pijn.

\subsubsection{VARIABELEN MET BETREKKING TOT DE HUISARTS EN ZIJN PRAKTIJK}

\section{VARIABELE 13. Het samenwerkingsverband.}

Beschrijving. Hierbij onderscheiden we samenwerkingsverbanden tussen artsen onderling, zoals associaties en groepspraktijken, en samenwerkingsverbanden tussen artsen en medewerkers uit andere disciplines werkzaam in de eerstelijns gezondheidszorg, zoals gezondheidscentra. Omdat in de regio waarover het onderzoek zich uitstrekt, ten tijde van het onderzoek geen groepspraktijken en gezondheidscentra beschikbaar waren, werden alléén associaties en solopraktijken onderzocht. 
Literatuur. Bouma en Tumstra, Huisarts en Wetenschap 1977 pag. $131-135:$,Samenwerkingsverbanden in de eerstelijns gezondheidszorg ontstaan de laatste jaren steeds meer. De motieven van de artsen om in groepsverband te gaan samenwerken zijn veelal de gunstiger werkomstandigheden, speciaal ten aanzien van vervangingsmogelijkheden en intercollegiaal overleg. Lijkt voor de arts een groepspraktijk veel voordelen te hebben, voor de patient is dit niet altijd zonder meer duidelijk. Het is mogelijk dat schaalvergroting als een bedreiging voor de artspatiënt relatie wordt gezien. Begrippen als massaliteit en verzakelijking worden in de discussie regelmatig gebruikt".

VAN Es 1969 pag. $277 \sim 284$, gaf als de belangrijkste motieven aan om tot een groepspraktijk over te gaan:

a. Een kwaliteitsverbetering in de praktijkvoering.

b. Vereenzaming in de beroepsuitoefening opheffen.

c. Meer vrijheid in persoonlijk- en gezinsleven.

Crebolder, Huisarts en Wetenschap 1977 pag. 301 - 305, constateerde op grond van zijn onderzoek dat professionalisatie van de eerstelijns gezondheidszorg i.c. het formeren van een gezondheidscentrum de persoonlijke band tussen patiënt en huisarts niet nadelig beïnvloedt.

Relatie tot de hypothese. Omdat de laatste jaren steeds meer samenwerkingsverbanden in Nederland tot stand komen, is het van belang te onderzoeken of er een verschil in uitstelduur bestaat tussen solopraktijken en praktijken werkend in een samenwerkingsverband. Hypothese XI stelt dat patiënten in associatiepraktijken langer uitstellen dan in solopraktijken.

\section{VARIABELE 14. De spreekuurvorm.}

Beschrijving. In dit onderzoek wordt een onderscheid gemaakt tussen arspraakspreekuren en vrije spreekuren. Hierbij moeten we ons ervan bewust zijn dat een exclusieve spreekuurvorm, in de zin van, uitsluitend op afspraak' of ,uitsluitend vrij spreekuur' vrijwel niet bestaat. Ieder spreekuur zal een mengvorm zijn van zowel afspraak- als vrij spreekuur. In ons onderzoek wordt met een afspraak- c.q. vrij spreekuur bedoeld, een spreekuurvorm met overwegend de kenmerken van een afspraakc.q. vrij spreekuur.

We onderscheiden:

a. Afspraakspreekuren, uitsluitend op afspraak. 
b. Afspraakspreekuren, voorafgegaan door een kort vrij spreekuur.

c. 's Morgens vrij spreekuur en 's middags afspraakspreekuur.

d. Vrij spreekuur met de mogelijkheid tot afspraak maken b.v. 's avonds.

e. Uitsluitend vrij spreekuur.

In het onderzoek werden de afspraakspreekuren a. en b. resp. de vrije spreekuren d. en e. onderzocht. Spreekuurvorm c. valt buiten ons onderzoek, omdat geen deelnemend arts deze spreekuurvorm hanteerde.

Literatuur. Kessel en ShePherd 1965, constateerden dat mensen die zelden of nooit de huisarts consulteerden, kritischer waren ten opzichte van de dienstverlening van de huisarts, zoals wachttijden, voorschrijfpatroon en de mate van informatie die de huisarts gaf.

Bouma en Tumstra, Huisarts en Wetenschap 1977 pag. 132, ondervonden toen zij overgingen van het vrije naar het afspraakspreekuur, dat in $11 / 2$ jaar tijds nog $29 \%$ van hun patiënten een of meermalen het korte vrije spreekuur van $08.00-08.30$ uur bezochten. Achtentachtig procent van hun patiënten achtte dit vrije spreekuur belangrijk als mogelijkheid bij acute gevallen.

Relatie tot de hypothese. Hypothese XII stelt dat patiënten in praktijken met afspraakspreekuren langer uitstellen dan patiënten in praktijken met vrije spreekuren.

\section{VARIABELE 15. De praktijkgrootte.}

Beschrijving. Onder de praktijkgrootte wordt het totaal aantal patiënten in een praktijk verstaan. Dus zowel de ziekenfondsen als de particulieren te zamen.

Indeling praktijkgrootte:

1. Praktijken $<2000$ patiënten.

2. Praktijken van 2000 t.m. 3000 patiënten.

3. Praktijken van 3001 t.m. 4000 patiënten.

4. Praktijken $>4000$ patiënten.

Literatuur. Uit de literatuur blijkt (TEN CATE 1973 pag. 30-31) dat de gemiddelde wachttijd van patiënten, alvorens de arts te consulteren, in grotere praktijken langer is dan in kleinere praktijken. Volgens KESSEL en SHEPHERD 1965, vertonen lange wachttijden samenhang met de uitstelduur. Daarnaast blijken huisartsen in grotere praktijken vaker naar spe- 
cialisten te verwijzen, en schrijven zij meer medicijnen voor per patiënt dan huisartsen in kleinere praktijken.

Relatie tot de hypothese. Hypothese XIII stelt dat patiënten in grotere praktijken langer uitstellen dan patiënten in kleinere praktijken.

VARIABELE 16. De leeftijd van de arts.

Beschrijving. De leeftijden van de huisartsen werden ingedeeld in twee groepen:

a. Jongere huisartsen: $<40$ jaar.

b. Oudere huisartsen: $\geqslant 40$ jaar.

Literatuur. VAN Es 1969 pag. 26, stelt dat menige praktijkpopulatie veroudert met het ouder worden van de huisarts. En zoals we in het voorgaande zagen neigen oudere patiënten tot langer uitstellen.

Relatie tot de hypothese. Hypothese XIV stelt dat patiënten bij oudere huisartsen langer uitstellen dan bij jongere huisartsen.

Tot zover de variabelen die in het onderzoek een rol spelen.

Bij onderzoekingen als deze is verkieslijk aanvankelijk zoveel mogelijk kenmerken in het onderzoek op te nemen. Verscheidene malen bleek echter een reductie van het aantal variabelen nodig te zijn.

Bij bestudering van de frequentietabellen van de variabelen bleek, dat bij sommige variabelen bepaalde categorieën nauwelijks scoorden. Door bij deze variabelen een aantal categorieën samen te trekken was het mogelijk bij deze variabelen alle categorieën voldoende gevuld te krijgen.

Deze samentrekkingen waren nodig bij:

a. De uitstelduur, waarvan de categorieën door samenvoeging teruggebracht werden van 7 naar 4 uitstelperioden.

b. Behalve bij de toetsing van hypothese VII werden alle klachten samengebundeld tot 10 groepen, al naar gelang het orgaansysteem waarin de klachten voorkwamen. Soms werden deze 10 groepen opnieuw teruggebracht tot 7 groepen.

c. Zowel van de patiënt als van de arts werden de 4 leeftijdsgroepen teruggebracht tot 2 groepen.

d. De consultfrequenties werden van 4 naar 3 groepen teruggebracht. 
Daar waar deze samenvoegingen werden toegepast, is dit in het onderzoek steeds duidelijk aangegeven.

$\mathrm{Na}$ uitvoering van het veldwerk door de huisartsen en bestudering van de verkregen gegevens, bleek dat enkele variabelen buiten beschouwing moesten worden gelaten. De redenen hiervan waren dat of bepaalde waarnemingseenheden waren uitgevallen, de zgn. nonrespons; of omdat bijna alle respondenten in één categorie vielen; of omdat de beantwoording onnauwkeurig had plaatsgevonden; of omdat de samenhang van de variabelen met de uitstelduur niet relevant was.

Wegens nonrespons vielen uit het aantal thuiswonende kinderen in het gezin, leeftijden van de oudste en jongste thuiswonende kinderen, datum eventuele ziekmelding. Aan de hand van het aantal thuiswonende kinderen en hun leeftijdsopbouw werd getracht een indruk te krijgen over de gezinssamenstelling van de patiënt. Door onderlinge raadpleging kan de gezinssamenstelling invloed uitoefenen op de uitstelduur van de patiënt.

Wegens het minder discrimineren van de variabelen, doordat de respondenten bijna allemaal in één categorie vielen, werd de variabele ,ernstige ziektes, ongeval of groot verlies in recent verleden in gezin', verwijderd. Deze variabele kon een verklaring zijn voor een inadequaat uitstel. Wegens onnauwkeurige beantwoording kwam de variabele ,burgelijke staat' van de patiënt te vervallen. Deze variabele moest ons enige indruk geven of de patiënt alleenstaand was, of dat hij in een bepaald gezinsverband samenleefde. Echter ongehuwden kunnen ook in een gezinsverband leven, bijvoorbeeld kinderen bij hun ouders. Ook ten aanzien van weduwen en weduwnaren was van tevoren geen duidelijke afspraak gemaakt, zodat deze bij beide categorieën konden worden ingevuld. Daarbij geeft deze variabele geen enkele aanduidling over het al of niet alleen wonen van weduwen en weduwnaren.

Ten aanzien van de sociale status van de patiënt werd kiezend uit opleiding, beroep en verzekeringsvorm, gekozen voor opleiding omdat deze de minst dubbelzinnige was en de meeste antwoordcategorieën had. 


\section{Beschrijving populatie aan de hand van de variabelen}

\subsection{INLEIDING}

In beide voorgaande hoofdstukken werden de hypothesen, de variabelen, de opzet en de uitvoering van het onderzoek behandeld. In dit hoofdstuk wordt eerst een indeling van de populatie gegeven aan de hand van de uitstelduur (variabele 1) en vervolgens aan de hand van kenmerken van de patiënt, kenmerken van de klacht en kenmerken van de huisarts in relatie tot diens praktijk.

Het onderscheiden van typen variabelen is wan belang voor de wijze van toetsing.

Bij de beschrijving van een populatie onderscheidt men de volgende typen variabelen; zie JONGE, H. DE (1964) Inleiding tot de medische statistiek:

A. Nominale variabelen, bestaande uit waarden die géén intrinsieke volgorde bezitten. Voorbeeld: Het bloedgroepensysteem A, B, AB en 0 , of een systeem van drie kleuren b.v. rood, groen en blauw.

B. Ordinale variabelen, bestaande uit waarden die een intrinsieke volgorde bezitten. Zij ontstaan vaak als men te maken heeft met een grootheid waarvan de waarden niet kwantitatief kunnen worden bepaald. Voorbeeld: De mate van verbetering van patiënten na een therapie b.v. genezen - sterk verbeterd - verbeterd - niet verbeterd verslechterd; of kenmerken als laag, midden en hoog.

C. Metrische variabelen, bestaande uit waarden die een maat of getal kunnen aannemen. Voorbeeld: De lichaamslengte, de leeftijd, de bloeddruk, gehele getallen zoals de resultaten van tellingen.

ad A. Hypothesen betreffende nominale variabelen kunnen getoetst worden met behulp van de chi-kwadraat toets. Deze chi-kwadraat toets kan gebruikt worden om: 
(1) Met behulp van associatietabellen de nulhypothese te toetsen, dat twee systemen onderling onafhankelijk zijn, met als alternatieve hypothese dat een samenhang aanwezig is.

(2) De nulhypothese te toetsen, dat een aantal populatieverdelingen (b.w. bij mannen en vrouwen) hetzelfde zijn.

Bij de chi-kwadraat toets wordt uit de kruistabel (associatietabel etc.) een grootheid $G$ uitgerekend, die onder de nulhypothese bij benadering een verdeling heeft, waarbij de vrijheidsgraden bepaald worden door de dimensies van de tabel. Gemakshalve duiden we $G$ aan met chi-kwadraat. Bij de berekening van chikwadraat wordt gekeken naar de verschillen tussen de, op grond van de randfrequenties en op grond van de nulhypothese, te verwachten waarde en de waargenomen waarde. Als alle waargenomen en verwachte waarden precies gelijk zijn, dan is chi-kwadraat gelijk $O$. Hoe verder de waargenomen verdeling afwijkt van de verwachte verdeling, hoe groter chi-kwadraat wordt. Dus bij een lage waardle van chi-kwadraat een goede, en bij een hoge waarde van chi-kwadraat een slechte overeenstemming tussen de waargenomen en de verwachte waarden. De significantiedrempel wordt meestal bij eenzijdige toetsingen gelegd bij $10 \%$, en bij tweezijdige toetsingen bij $5 \%$. Daarmee wordt bedoeld dat er slechts $10 \%$ resp. $5 \%$ kans is dat de uitkomst toch aan het toeval kan worden toegeschreven.

ad B. Worden in een onderzoek ordinale variabelen gebruikt, dan kan het onderzoek naar de mate van associatie tussen twee grootheden worden verricht met behulp van b.w. Kendall's Tau B en C (zie Statistical Package for the Social Sciences door NoRMaN H. NIE en medewerkers).

Kendall's Tau B resp. Kendall's Tau C spoort verbanden op in een tabel met een gelijk aantal rijen en kolommen resp. in tabellen met een ongelijk aantal rijen en kolommen. In tegenstelling tot chi-kwadraat, die géén grootte en richting aangeeft, maar alleen toetst òf een verschil aanwezig is, geeft Kendall's Tau wèl de grootte en richting aan van het verband. De waarde van Kendall's Tau ligt tussen -1 en +1 . Bij +1 is een $100 \%$ positief verband, en bij -1 een $100 \%$ negatief verband aanwezig. Bij een waarde gelijk 0 is geen verband aanwezig. Voorbeeld: In een tabel wordt op de verticale as de uitstelduur van 0 tot en met 3 uitgezet, en op de horizontale as het geslacht van de patiënt 
$(0=$ vrouw en $1=$ man.). Is Kendall's Tau positief dan stelt 1 $(=$ man) op de horizontale as langer uit dan $0(=$ vrouw $)$, en bij een negatieve waarde van Kendall's Tau zou 0 (= vrouw) langer uitstellen dan $1(=\operatorname{man})$. Niet alleen wordt dus nagegaan of de verwachte waarden van de gevonden waarden afwijken, maar of deze afwijkingen een ordinaal verloop hebben.

ad C. Bij metrische wariabelen kan vaak worden gewerkt met correlatie- en regressierekening. In strikte zin kunnen een aantal van de gebruikte variabelen niet als metrisch worden beschouwd. Toch vormen correlatie- en regressierekening vaak de meest aangewezen weg om bepaalde problemen rond de multivariate samenhangen tussen meer dan twee variabelen op te lossen. In hoofdstuk IV, waarin de afzonderlijke hypothesen worden getoetst, worden de variabelen als ordinaal c.q. nominaal behandeld. In hoofdstuk $\mathrm{V}$, waarin multivariate samenhangen worden nagegaan, worden zij in één van de twee analyses als metrisch opgevat.

In dit onderzoek wordt gesproken van een significant verschil bij $\mathbf{P}$ $<0,1$. Alle tabellen waarbij een significant verschil geconstateerd wordt, worden in de bijlage vermeld.

Aan het onderzoek namen deel (zie pag. 29):

20 Huisartsen (volledig);

deze registreerden in totaal 1989 consulten.

2 Huisartsen (gedeeltelijk); deze registreerden in totaal 81 consulten.

Totaal

2070 consulten.

Wellicht ten overvloede wil ik er nog eens op wijzen, dat de onderzoekpopulatie bestaat uit patiënten, die gedurende een bepaalde periode hun huisarts consulteerden vanwege een , nieuwe klacht'. Uit de onderzoekgegevens kunnen dus geen conclusies worden getrokken omtrent de morbiditeit in de betreffende huisartsenpraktijken, noch omtrent de mate waarin deze klachten zich voordoen.

Opgemerkt dient nog te worden, dat als gevolg van gemiste of onvolledige waarnemingen, $\mathbf{N}$ niet steeds 2070 is. 
De opbouw van dit hoofdstuk is verder als volgt. Allereerst wordt in de tweede paragraaf een beschrijving gegeven van de uitstelduur. Daarna wordt in de derde paragraaf de populatie beschreven aan de hand van kenmerken van de patiënt, waarna in de vierde paragraaf de beschrijving van de populatie plaatsvindt aan de hand van kenmerken van de klacht. In de vijfde paragraaf wordt tenslotte de populatie beschreven aan de hand van kenmerken van de huisarts en diens praktijk.

\subsection{VARIABELE 1: DE UITSTELDUUR}

Een beschrijving van de uitstelduur werd op pagina 33 weergegegeven. Tijdens het consult werd de patiënt gevraagd, sinds hoe lang hij de klacht op dàt moment had. De resultaten van deze vraagstelling worden in tabel 3.2.1. weergegeven.

Tabel 3.2.1. Duur van de klachten, op moment van consult.

\begin{tabular}{lrc}
\hline Duur van de klacht & $\%$ & $\begin{array}{c}\text { van de praktijkscores } \\
\text { empirische reikwijdte }\end{array}$ \\
\hline tijdsduur $<1$ dag & 5 & $0 \longleftrightarrow 16$ \\
1 dag & 5 & $0 \longleftrightarrow 17$ \\
$1 \quad$ dag $<$ tijdsduur $\leqslant 3$ dagen & 20 & $3 \longleftrightarrow 34$ \\
3 dagen $<$ tijdsduur $\leqslant 7$ dagen & 15 & $2 \longleftrightarrow 27$ \\
1 week $<$ tijdsduur $\leqslant 3$ weken & 23 & $7 \longleftrightarrow 32$ \\
3 weken $<$ tijdlsduur $\leqslant 6$ weken & 7 & $1 \longleftrightarrow 15$ \\
6 weken $<$ tijdsduur & 25 & $4 \longleftrightarrow 74$ \\
\hline Totaal & 100 & $(\mathbb{N}=2055)$ \\
\hline
\end{tabular}

Uit deze tabel 3.2.1. blijkt, dat bij éen op de vier onderzochte consulten $(25 \%)$ het langer dan zes weken duurde voordat de huisarts werd geraadpleegd.

Bij afspraakspreekuren wordt, ter verkrijging van de uitstelduur, van deze ,duur van de klacht' de tijdsduur, vanaf het maken van een afspraak tot het consult, in mindering gebracht.

In de meeste gevallen (91\%) was de tijdsduur tussen het moment van afspraak maken en het moment van consult, niet langer dan 1 dag. Slechts in $2 \%$ van de gevallen duurde dit langer dan 3 dagen. In de te 
onderzoeken praktijken lijkt de bereikbaarheid van de huisartsen goed georganiseerd te zijn.

Teneinde tot een overzichtelijke en verantwoorde verdeling te komen, gebruikten we voor de uitstelduur de indeling: 0, 1, 2 en 3 (zie pag. 34). In tabel 3.2.2. en figuur 1 (diagram) wordt de uitstelduur van de patiënten bij de onderzochte klachten weergegeven.

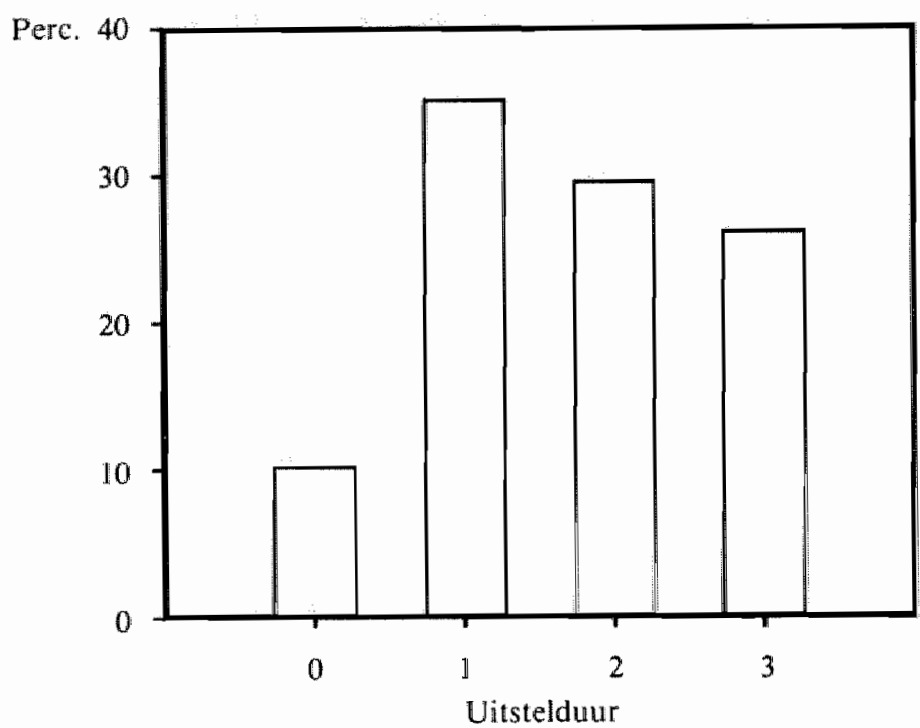

Fig. 1. Percentages onderzochte patienten in relatie tot de witstelduur.

Tabel 3.2.2. Uitstelduur van patienten in de onderzoekpopulatie.

\begin{tabular}{|c|c|c|}
\hline Uitstelduur & $\%$ & $\begin{array}{l}\text { empirische reikwijdte } \\
\text { van de praktijkscores }\end{array}$ \\
\hline (uitstelduur $\leqslant 1$ dag) & 9 & $1 \longleftrightarrow 27$ \\
\hline $1 \quad(1 \mathrm{dag}<$ uitstelduur $\leqslant 7$ dagen $)$ & 35 & $19 \longleftrightarrow 48$ \\
\hline 2 (1 week $<$ uitstelduur $\leqslant 3$ woken $)$ & 30 & $6 \longrightarrow 44$ \\
\hline 3 ( 3 weken $<$ uitstelduur) & 26 & $10 \longleftrightarrow 74$ \\
\hline Totanl & 100 & $(\mathrm{~N}=2055)$ \\
\hline
\end{tabular}




\subsection{BESCHRIJVING POPULATIE AAN DE HAND VAN KENMERKEN VAN DE PATIENT}

Allereerst volgt een indeling van de populatie aan de hand van de basisvariabelen: leeftijd, geslacht en opleiding van de patiënt. Daarna volgt een indeling aan de hand van de overige onderzochte variabelen van de patiënt (zie pag. 33).

\subsubsection{VARIABELE 2: LEEFTIJD VAN DE PATLENT}

Tabel 3.3.1.1. Leeftijd ran de patiënten in de populatie.

\begin{tabular}{lcc}
\hline Leeftijd patiënt & $\%$ & $\begin{array}{c}\text { empirische reikwijdte } \\
\text { van de praktijkscores }\end{array}$ \\
\hline $17-45$ jaar & 66 & $38 \longleftrightarrow 79$ \\
$\geqslant 46$ jaar & 34 & $21 \longleftrightarrow 62$ \\
\hline Totaal & $100 \quad(\mathrm{~N}=2045)$ \\
\hline
\end{tabular}

Ten aanzien van de leeftijd werden de patiënten ingedeeld in jongere en oudere patiënten, waarbij we onder jongere patiënten verstaan patiënten van 17 - 45 jaar, en onder oudere patiënten patiënten van 46 jaar en ouder. De onderzoekpopulatie bleek voor tweederde deel te bestaan uit jongere patiënten.

\subsubsection{VARIABELE 3: GESLACHT VAN DE PATIENT}

Tabel 3.3.2.1. Geslachtsverdeling patiënten in de populatie.

\begin{tabular}{lcc}
\hline Geslacht & $\%$ & $\begin{array}{c}\text { empirische reikwijdte } \\
\text { van de praktijkscores }\end{array}$ \\
\hline Vrouw & 57 & $42 \leftrightarrow 65$ \\
Man & 43 & $35 \leftrightarrow 58$ \\
\hline Totaal & $100 \quad(\mathrm{~N}=2045)$ \\
\hline
\end{tabular}

Vrouwen bleken in de onderzochte populatie sterker vertegenwoordigd dan mannen. Ten aanzien van de praktijken onderling bleken geen grote verschillen aanwezig te zijn. 
Tabel 3.3.3.1. Opleidingsnivean van patiënten in de populatie.

\begin{tabular}{lrc}
\hline Opleiding & $\%$ & $\begin{array}{c}\text { empirische reikwijdte } \\
\text { van de praktijkscores }\end{array}$ \\
\hline Laag & 63 & $44 \longleftrightarrow 84$ \\
Midden & 28 & $14 \longleftrightarrow 44$ \\
Hoog & 9 & $1 \leftrightarrow 29$ \\
\hline Totaal & $100 \quad(\mathrm{~N}=2055)$ \\
\hline
\end{tabular}

Bij bestudering van het opleidingsniveau van patiënten (Zie tabel 3.3.3.1.) bleek, dat de onderzoekpopulatie voor bijna tweederde deel bestond uit patiënten met een ,lagere opleiding' en voor bijna eenderde deel uit patiënten met een ,midden opleiding'. Voor nog geen eentiende deel bestond de populatie uit patiënten met een ,hogere opleiding'. Per praktijk bleek het opleidingsniveau van de onderzochte patiënten aanzienlijk te verschillen.

In de groep patiënten met een, lagere opleiding' kwamen relatief meer oudere patiënten voor, en in de groep patiënten met een ,midden opleiding' relatief meer jongere patiënten (Zie bijlage II, tabel 3.3.3.2.).

Oudere mannen resp. jongere vrouwen kwamen relatief meer voor in de groep patiënten met een ,hogere opleiding' (Zie bijlage II, tabel 3.3.3.3., 3.3.3.5. en 3.3.3.6.). Oudere vrouwen bleken relatief meer in de groep patiënten met een ,lagere opleiding' voor te komen, en relatief minder in de groep patiënten met een ,hogere opleiding' (Zie bijlage II, tabel 3.3.3.4. en 3.3.3.6.). Een aannemelijke verklaring hiervoor is dat mannen gedurende hun leven doorgaans op sociaal-maatschappelijk niveau stijgen (bijvoorbeeld door middel van avondstudies en/of promoties op hun werk), terwijl vrouwen, als huisvrouwen deze mogelijkheid doorgaans niet hebben. De sociale status van vrouwen wordt praktisch uitsluitend door hun opleiding bepaald.

\subsubsection{VARIABELE 5: FREQUENTIE HUISARTSENBEZOEK}

In onderstaande tabel worden van de onderzoekpopulatie de consultfrequenties gedurende het afgelopen jaar weergegeven, waarbij het geregistreerde consult niet werd meegerekend. 
Tabel 3.3.4.1. Consultrequenties gedurende het afgelopen jaar.

\begin{tabular}{lcc}
\hline Consultfrequenties & $\%$ & $\begin{array}{c}\text { empirische reikwijdte } \\
\text { van de praktijkscores }\end{array}$ \\
\hline Weinig $\quad(0-3 \mathrm{maal})$ & 34 & $1 \longleftrightarrow 69$ \\
Normaal $\quad(4-6 \mathrm{maal})$ & 44 & $27 \longleftrightarrow 76$ \\
Vaak $\quad(\geqslant 7$ maal $)$ & 22 & $4 \longleftrightarrow 47$ \\
\hline Totaal & $100 \quad(\mathrm{~N}=2064)$ \\
\hline
\end{tabular}

Oudere patiënten in de populatie bleken naar verhouding hun huisarts vaker te raadplegen dan jongere patiënten; dit geldt vooral voor oudere vrouwen (Zie bijlage II, tabel 3.3.4.2., 3.3.4.3. en 3.3.4.4.).

Patiënten in de populatie met een hogere opleiding waren ten opzichte van patiënten met een lagere opleiding in de minderheid wat betreft frequentie van raadplegen (Zie bijlage II, tabel 3.3.4.5.).

\subsubsection{VARIABELE 6: STADS- OF PLATTELANDSPATIENTEN}

Aan het onderzoek werd deelgenomen door 22 huisartsen, uit 10 stadsen 12 plattelandspraktijken (zie pag. 37). In tabel 3.3.5.1. wordt aangegeven welk gedeelte van de onderzoekpopulatie ingeschreven stond in stads- en plattelandspraktijken.

Tabel 3.3.5.1. Percentage patiënten wan de onderzoekpopulatie ingeschreven in stads- en plattelandspraktijken.

\begin{tabular}{lcc}
\hline & $\%$ & \\
\hline In plattelandspraktijiken & 55 & \\
In stadspraktijken & 45 & \\
\hline Total & $100 \quad(\mathrm{~N}=2070)$ \\
\hline
\end{tabular}

Jongere patiënten bleken relatief meer in plattelandspraktijken voor te komen en oudere patiënten relatief meer in stadspraktijken (Zie bijlage II, tabel 3.3.5.2.).

Ten aanzien van geslacht en opleidingsniveau van de patiënt bleek dat tussen patiënten, afkomstig uit stads- resp. plattelandspraktijken, geen verschil in voorkomen aantoonbaar was. 
Uit onderstaande tabel blijkt, dat meer dan de helft van het aantal patiënten ( $52 \%$ ) aangaf, ervaring te hebben met de klacht.

Tabel 3.3.6.1. Percentage patiënten in de populatie, dat al of geen ervaring had met de klacht.

\begin{tabular}{lcc}
\hline & $\%$ & $\begin{array}{c}\text { empirische reikwijdte } \\
\text { van de praktijkscores }\end{array}$ \\
\hline Ervaring met dle klacht & 52 & $36 \longleftrightarrow 83$ \\
Geen erwaring met de klacht & 48 & $17 \longleftrightarrow 64$ \\
\hline Totaal & $100 \quad(\mathbb{N}=2054)$ \\
\hline
\end{tabular}

Dat oudere patiënten relatief meer ervaring aangaven dan jongere patiënten (Zie bijlage II, tabel 3.3.6.2.), komt overeen met onze verwachting. De ervaring neemt nu eenmaal toe met de leeftijd. Opvallend was dat dit wel voor vrouwen aantoonbaar was, maar niet voor mannen (Zie bijlage II, tabel 3.3.6.3.).

Patiënten met een hogere opleiding waren ten opzichte van de patiënten met een lagere opleiding in de minderheid wat betreft ervaring met de klacht (Zie bijlage II, tabel 3.3.6.4.).

\subsection{BESCHRIJVING POPULATIE AAN DE HAND VAN KENMERKEN VAN DE KLACHT}

Allereerst worden van de geregistreerde klachten de frequenties weergegeven, daarna volgt de indeling van de klachten in groepen met de daarbij horende percentages. Vervolgens wordt de onderlinge samenhang van persoons- en ziektekenmerken beschreven aan de hand van de basisvariabelen van de patiënt, waarna voor zover mogelijk een beschrijving volgt aan de hand van de overige variabelen van de patiënt (zie pag. 33). 


\subsubsection{VARIABELE 8: DE KLACHT}

In onderstaande tabel worden van alle klachten, die tijdens het onderzoek geregistreerd werden, de frequenties weergegeven.

Tabel 3.4.1.1. ,Nieuwe klachten" in de onderzoekpopulatie in volgonde van woor komen.

\begin{tabular}{|c|c|c|c|}
\hline \multicolumn{2}{|c|}{ Aantal } & \multicolumn{2}{|c|}{ Aantal } \\
\hline Pijn in de rug & 160 & ,Overige' klachten van het & \\
\hline Hoesten & 150 & bewegingsapparaat & 24 \\
\hline Gewrichtspijn & 134 & 'Overige' huidklachten & 24 \\
\hline Hoofdpijn & 108 & Beklemid gevoel & 23 \\
\hline Keelpijn & 106 & Braken & 23 \\
\hline Spierpijn & 104 & Slapeloosheid & 17 \\
\hline Huiduitslag & 102 & Visusklachten & 17 \\
\hline Nervositas & 76 & Misselijkheid & 17 \\
\hline "Overige" algemene klachten & 74 & ,Overige' urogenitaalklachten & 16 \\
\hline Duizeligheid & 64 & Pijn in de lendenen & 15 \\
\hline Knobbeltje & 63 & Dikke enkels & 14 \\
\hline Anticonceptieprobleem & 62 & Fertiliteitsprobleem & 13 \\
\hline Buikkrampen & 58 & „Overige' k.n.o--klachten & 1.3 \\
\hline Pijn bij plassen & 55 & Anaalklachten & 12 \\
\hline Margpijn & 54 & Eerste pilconsult & 12 \\
\hline Mensesklachten & 50 & Koorts & 10 \\
\hline Moeheid & 50 & ,Overige' buikklachten & 9 \\
\hline Pijn op de borst & 44 & Te dik & 9 \\
\hline Hartkloppingen & 42 & Transpireren & 8 \\
\hline Benauwdheid & 40 & Oorsuizen & 8 \\
\hline Oorpifin & 34 & Maagzuur & 7 \\
\hline Slecht horen & 29 & Obstipatie & 7 \\
\hline Verstopte neus & 26 & Neusbloeding & 4 \\
\hline ,Overige' sexualiteitsproblemen & 25 & Overige' hartklachten & 2 \\
\hline Jeuk & 25 & „Overige' gezwellen & 1 \\
\hline Diarrhee & 24 & & \\
\hline & & Totaal & 064 \\
\hline
\end{tabular}




\subsubsection{VARIABELE 9: INDELING VAN DE KLACHT NAAR ORGAANSTEISEL.}

Uit onderstaande tabel blijkt dlat êén op de vijf ,nieuwe klachten', die aan de huisarts worden voorgelegd, betrekking hebben op het bewegingsapparaat.

Tabel 3.4.2.1. Indeling klachten naar orgaanstelsel, in volgorde van voorkomen.

\begin{tabular}{lcc}
\hline Klachtengroepen & $\%$ & $\begin{array}{c}\text { empirische reikwijdte } \\
\text { van de praktijkscores }\end{array}$ \\
\hline Algemene klachten & 21 & $11 \longleftrightarrow 38$ \\
Klachten van het bewegingsapparaat & 20 & $8 \longleftrightarrow 34$ \\
K.n.o.klachten & 11 & $5 \longleftrightarrow 17$ \\
Buikklachten & 11 & $5 \longleftrightarrow 16$ \\
Klachten van de luchtwegen & 9 & $4 \longleftrightarrow 16$ \\
Huidklachten & 7 & $2 \longleftrightarrow 15$ \\
Urogenitaalklachten & 7 & $2 \longleftrightarrow 15$ \\
Hartklachten & 6 & $0 \longleftrightarrow 19$ \\
Sexualiteitspioblemen & 5 & $0 \longleftrightarrow 19$ \\
Gezwellen & 3 & $0 \longleftrightarrow 7$ \\
Totaal & 100 & $(\mathrm{~N}=2050)$ \\
\hline
\end{tabular}

Ten aanzien van de leeftijd en het geslacht van de patiënt bleek (Zie bijlage II, tabel 3.4.2.2., 3.4.2.3., 3.4.2.4. en 3.4.2.5.):

- de groep ,k.n.o.-klachten of klachten van de luchtwegen' relatief meer bij mannen voor te komen dan bij vrouwen;

- de groep hartklachten bij oudere patiënten vier maal zo vaak voor te komen als bij jongere patiënten. Tussen mannen en vrouwen was geen verschil aantoonbaar;

- de groep buikklachten relatief meer bij jongeren dan bij ouderen voor te komen. Bij mannen was dit verschil groter dan bij vrouwen;

- de groep urogenitaalklachten tot relatief meer consulten bij vrouwen dan bij mannen te leiden, waarbij bovendien meer oudere dan jongere vrouwen betrokken waren;

- de groep klachten van het bewegingsapparaat relatief meer bij ouderen resp. mannen voor te komen dan bij jongeren resp. vrouwen, waarbij relatief meer oudere dan jongere vrouwen betrokken waren. Opvallend was dat deze klachten relatief meer bij jongere dan bij 
oudere mannen voorkwamen! Waarschijnlijk speelt hier het groter aantal (sport)trauma's bij jongere mannen een rol;

- de groep ,gezwellen of huidaandoeningen' relatief meer bij jongeren dan bij ouderen voor te komen. Dit verschil was bij vrouwen groter dan bij mannen;

- de groep sexualiteitsproblemen bij jongeren resp. vrouwen relatief veel vaker voor te komen dan bij ouderen resp. mannen. Het ,eerste pilconsult' speelt in deze groep een grote rol.

\subsubsection{VARLABELE 10: ERNST VAN DE KLACHT}

De beschrijving van de populatie aan de hand van de ernst van de klacht werd uitgevoerd met behulp van een kwartielindeling, zoals beschreven staat op pagina 41 en 42 .

Tabel 3.4.3.1. ,Ernst van de klacht' in de populatie.

\begin{tabular}{lcc}
\hline & $\%$ & $\begin{array}{c}\text { empirische reikwijdte } \\
\text { van de praktijkscores }\end{array}$ \\
\hline 11 meest ernstige klachten & 25 & $11 \longleftrightarrow 38$ \\
18 minder ernstige klachten & 48 & $34 \longleftrightarrow 69$ \\
11 minst ernstige klachten & 27 & $19 \longleftrightarrow 40$ \\
\hline Totaal & $100 \quad(N=1822)$ \\
\hline
\end{tabular}

De groep ,oudere patiënten' bleek relatief meer ernstige klachten naar voren te brengen dan de groep ,jongere patiënten' (Zie bijlage II, tabel 3.4.3.2.). Van de als ,ernstig' aangemerkte klachten bleek in de populatie het ,bespeuren van een knobbeltje' relatief meer door jongere patiënten (17-45 jr.) naar voren te worden gebracht, en ,dikke enkels' c.q. ,pijn op de borst" relatief meer door oudere patiënten $(\geqslant 46 \mathrm{jr}$.) (Zie bijlage II, tabel 3.4.3.4.). Van de als ,minst ernstig' aangemerkte klachten bleek in de populatie ,anticonceptieproblemen' relatief meer door jongere vrouwen, en ,spierpijn" relatief meer door oudere mannen te worden genoemd (Zie bijlage II, tabel 3.4.3.5. en 3.4.3.7.).

Mannen bleken in de populatie relatief meer ernstige klachten naar voren te brengen dan vrouwen (Zie bijlage II, tabel 3.4.3.3.). Van de als ,ernstig' aangemerkte klachten bleken in de populatie ,dikke enkels' c.q. ,pijn bij plassen' relatief meer door vrouwen naar voren te worden gebracht, en ,pijn op de borst' c.q. ,gewrichtspijn' relatief meer door man- 
nen (Zie bijlage II, tabel 3.4.3.6.). Tussen het opleidingsniveau van de patiënt en de ernst van de klacht was geen verband aantoonbaar.

\subsubsection{VARIABELE 11: KARAKTER VAN DE KLACHT}

Wat de klachtenindeling betreft in overwegend somatisch of psychisch, bleken tussen de praktijken onderling grote verschillen aanwezig te zijn. Vermoedelijk berust dit onderscheid eerder op een verschillende beoordeling van de klacht door de arts, dan op een verschil in praktijkpopulatie. In onderstaande tabel worden de verschillende karakters van de klacht in de populatie weergegeven.

Tabel 3.4.4.1. Karakter van de klacht, in volgorde van voorkomen.

\begin{tabular}{lcc}
\hline & $\%$ & $\begin{array}{c}\text { empirische reikwijdte } \\
\text { van de praktijkscores }\end{array}$ \\
\hline Somatische klachten & 68 & $43 \longleftrightarrow 90$ \\
Psychische klachten & 17 & $0 \longleftrightarrow 38$ \\
Psycho-somatische klachten & 12 & $1 \longleftrightarrow 47$ \\
Matschappelijke klachten & 3 & $0 \longleftrightarrow 16$ \\
\hline Totaal & $100 \quad(\mathrm{~N}=2001)$ \\
\hline
\end{tabular}

In de groep ,oudere patiënten' kwamen relatief meer psycho-somatische klachten voor en in de groep, jongere patiënten' relatief meer maatschappelijke klachten (Zie bijlage II, tabel 3.4.4.2.).

Mannen bleken in onze populatie relatief meer somatische klachten naar voren te brengen en vrouwen relatief meer psychische, psycho-somatische of maatschappelijke klachten, waarbij psycho-somatische klachten relatief meer bij oudere vrouwen voorkwamen en maatschappelijke klachten relatief meer bij jongere vrouwen (Zie bijlage II, tabel 3.4.4.3. en 3.4.4.4.). Patiënten die hun huisarts wegens overwegend somatische klachten consulteerden, bleken hun huisarts relatief minder vaak te raadplegen, dan patiënten die hun huisarts wegens overwegend psychische-, psycho-somatische- of maatschappelijke klachten consulteerden (Zie bijlage II, tabel 3.4.4.5.).

\subsubsection{VARIABELE 12: REDEN VAN CONSULTATIE}

De voornaamste reden waarom de patiënten nu met deze nieuwe klachten bij hun huisarts kwamen, wordt in onderstaande tabell weergegeven. 
Tabel 3.4.5.1. Voornaamste reden wasnom huisarts wegens nieuwe kichten werd geraadpleegd, in volgorde wan voorkomen.

\begin{tabular}{lcc}
\hline & 9 & $\begin{array}{c}\text { empirische reikwijdte } \\
\text { vam de praktijkscores }\end{array}$ \\
\hline Pijn & 26 & $4 \longleftrightarrow 46$ \\
Fysiek hinderlijk & 20 & $3 \longleftrightarrow 45$ \\
Ongerust & 20 & $8 \longleftrightarrow 36$ \\
Gaat niet spontaan over & 13 & $0 \longleftrightarrow 34$ \\
Ervaring met klacht & 5 & $0 \longleftrightarrow 22$ \\
Klacht verergert & 5 & $0 \longleftrightarrow 21$ \\
Andere reden dan klacht & 3 & $0 \longleftrightarrow 12$ \\
Gestuurd & 3 & $0 \longleftrightarrow 9$ \\
Socilaal hinderlijk & 3 & $0 \longleftrightarrow 10$ \\
Verzuimbehoefte & 2 & $0 \longleftrightarrow 12$ \\
\hline Totaal & 100 & $(\mathrm{~N}=2042)$ \\
\hline
\end{tabular}

Relatief meer vrouwen gaven ongerustheid aan als reden van consultatie, en relatief meer mannen pijn en verzuimbehoefte (Zie bijlage II, tabel 3.4.5.2.).

Jongere mannen bleken in de populatie relatief meer wegens pijn en verzuimbehoefte te consulteren, en oudere mannen relatief meer wegens fysieke en sociale hinder van de klacht (Zie bijlage II, tabel 3.4.5.3.). Jongere vrouwen bleken relatief meer pijn aan te geven als reden van consultatie, en oudere vrouwen relatief meer het niet spontaan overgaan van de klacht (Zie bijlage II, tabel 3.4.5.4.).

In tabel 3.4.5.5. wordt het verband aangegeven tussen de reden van consultatie en de indeling van de klacht in hoofdgroepen. In onderstaande hoofdgroepen van de klacht bleken enkele redenen van consultatie meer dan twee maal het populatiegemiddelde voor te komen.

Bijvoorbeeld:

- in de groep luchtwegaandoeningen, het niet spontaan overgaan van de klachten en verzuimbehoefte;

- in de groep hartklachten, ongerustheid;

- in de groep gezwellen, ongerustheid;

- in de groep klachten van het bewegingsapparaat, pijn en verzuimbehoefte;

- in de groep huidaandoeningen, sociale hinder;

- in de groep sexualiteitsproblemen, ongerustheid, ervaring met de klacht en sociale hinder. 


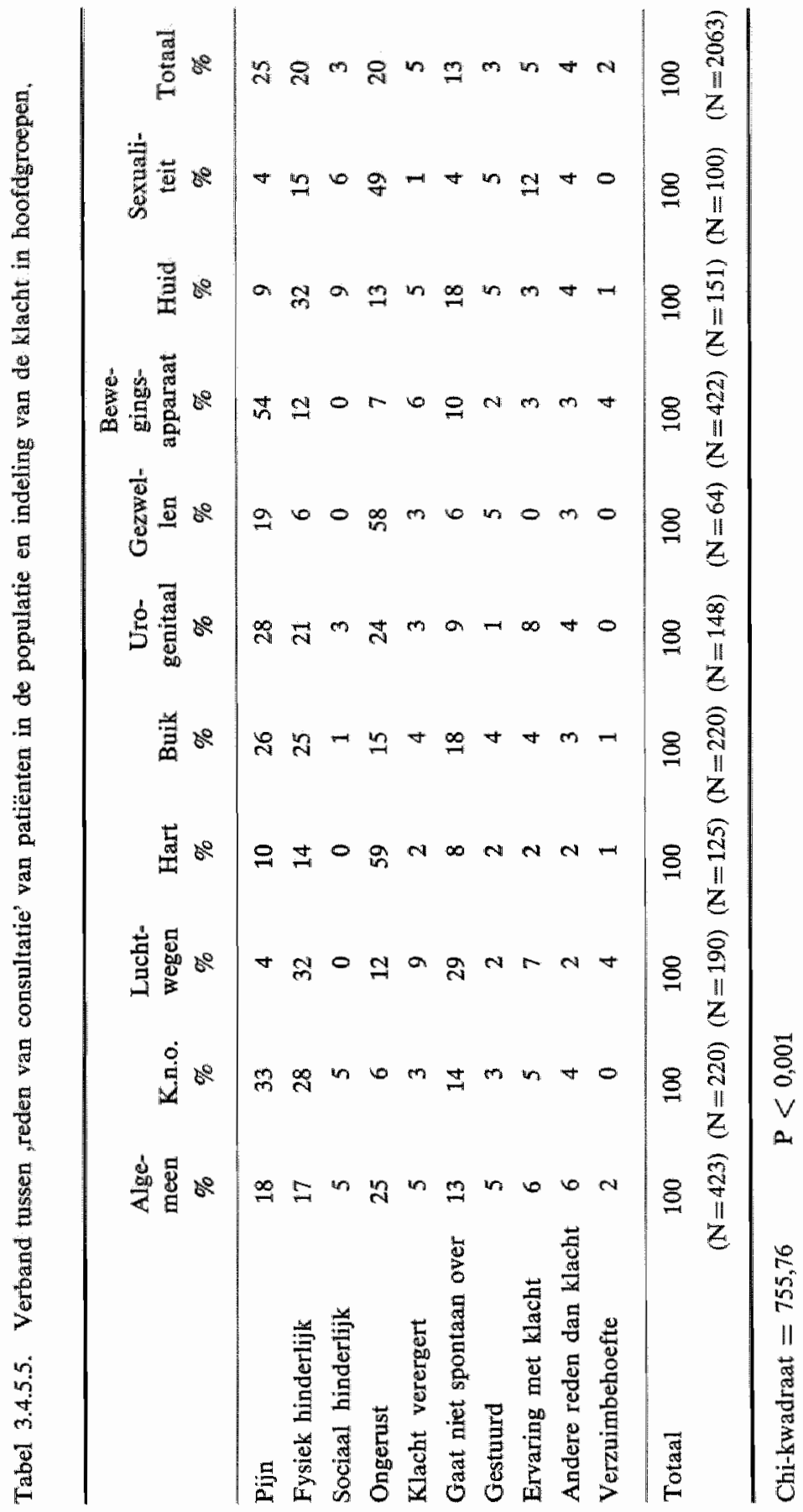


Patiënten die hun huisarts consulteerden wegens, verzuimbehoefte' bleken hun huisarts relatief vaker te consulteren dan patiënten die hun huisarts consulteerden wegens ,pijn' of ,hinder' (Zie bijlage II, tabel 3.4.5.6.).

In de groep somatische klachten bleek relatief meer, pijn' en ,fysieke hinder' als reden van consultatie voor te komen. In de groep psychische klachten relatief meer ,ongerustheid', gestuurd worden' en ,verzuimbehoefte'. In de groep psycho-somatische klachten relatief meer ,ongerustheid'. En in de groep maatschappelijke klachten relatief meer ,sociale hinder", ,verzuimbehoefte', ,ervaring met de klacht', ,andere reden dan klacht' en , ongerustheid'.

\subsection{BESCHRIJVING POPULATIE AAN DE HAND VAN KENMERKEN VAN DE HUISARTS EN ZIJN PRAKTIJK}

\subsubsection{VARIABELE 13: SAMENWERKINGSVERBAND}

Van de onderzochte patiënten was $72 \%$ ingeschreven in solopraktijken en $28 \%$ in associatiepraktijken.

In onderstaande tabel wordt van de onderzochte stads- en plattelandspraktijken het samenwerkingsverband aangegeven. Hierbij bleek dat zowel solo- als associatiepraktijken in de populatie gelijkelijk verdeeld waren over stad en platteland.

Tabel 3.5.1.1. Samenwerkingsverband in de onderzochte stads- en plattelandspraktijken.

\begin{tabular}{lccc}
\hline & $\begin{array}{c}\text { Stads- } \\
\text { praktijk } \\
\text { Aantal }\end{array}$ & $\begin{array}{c}\text { Plattelands- } \\
\text { praktijk } \\
\text { Aantal }\end{array}$ & $\begin{array}{c}\text { Totaal } \\
\text { Aantal }\end{array}$ \\
\hline Solopraktijken & 7 & 8 & 15 \\
Associatiepraktijken & 3 & 4 & 7 \\
\hline Totaal & 10 & 12 & 22 \\
\hline
\end{tabular}

Oudere patiënten c.q. oudere vrouwen bleken relatief meer in associatiepraktijken voor te komen, en jongere patiënten c.q. jongere vrouwen relatief meer in solopraktijken (Zie bijlage $\Pi$, tabel 3.5.1.2. en 3.5.1.3.). Ten aanzien van het opleidingsniveau bleek dat de onderzochte patiënten met hogere opleidingen relatief meer in associatiepraktijken voorkwamen, en met lagere opleidingen relatief meer in solopraktijken. (Zie bijlage II, tabel 3.5.1.4.). 


\subsubsection{VARIABELE 14: SPREEKUURVORM}

Van de patiënten in de populatie, die met ,nieuwe klachten' hun huisarts consulteerden, was $72 \%$ ingeschreven in praktijken met afspraakspreekuur en $28 \%$ in praktijken met vrij spreekuur.

In onderstaande tabel wordt van de onderzochte stads- en plattelandspraktijken de spreekuurvorm aangegeven. Hierbij bleken zowel afspraakals vrij spreekuur gelijkelijk vertegenwoordigd te zijn in de onderzochte stads- en plattelandspraktijken.

Tabel 3.5.2.1. Spreekuurvorm van de onderzochte stads- en plattelandspraktijken.

\begin{tabular}{lccc}
\hline & $\begin{array}{c}\text { Stads- } \\
\text { praktijk } \\
\text { Aantal }\end{array}$ & $\begin{array}{c}\text { Platteiands- } \\
\text { praktijk } \\
\text { Aantal }\end{array}$ & $\begin{array}{c}\text { Totaal } \\
\text { Aantall }\end{array}$ \\
\hline Vrij spreekwur & 2 & 4 & 6 \\
Afspraakspreekuur & 8 & 8 & 16 \\
\hline Totaal & 10 & 12 & 22 \\
\hline
\end{tabular}

In de volgende tabel wordt de spreekuurvorm aangegeven van de onderzochte solo- en associatiepraktijken. In de onderzochte praktijken bleken afspraakspreekuren relatief meer in associatiepraktijken voor te komen, en vrije spreekuren relatief meer in solopraktijken.

Tabel 3.5.2.2. Spreekuurvorm van de onderzochte solo- en associatiepraktijken.

\begin{tabular}{lccc}
\hline & $\begin{array}{c}\text { Solo- } \\
\text { praktijk } \\
\text { Aantal }\end{array}$ & $\begin{array}{c}\text { Associatie- } \\
\text { praktijk } \\
\text { Aantal }\end{array}$ & $\begin{array}{c}\text { Totaal } \\
\text { Aantal }\end{array}$ \\
\hline Vrij sprekkur & 5 & 1 & 6 \\
Afspraakspreekuur & 10 & 6 & 16 \\
\hline Total & 15 & 7 & 22 \\
\hline
\end{tabular}

Vrouwen bleken relatief meer in de onderzochte praktijken met afspraakspreekuur vertegenwoordigd te zijn, en mannen relatief meer in de onderzochte praktijken met vrij spreekuur (Zie bijlage II, tabel 3.5.2.3.). Ten aanzien van het opleidingsniveau bleek dat patiënten in de populatie met hogere opleidingen relatief meer in praktijken met afspraakspreek- 
unr voorkwamen, en patiënten met lagere opleidingen relatief meer in praktijken met vrij spreekuur (Zie bijlage $I I_{3}$ tabel 3.5.2.4.). Dil is in overeenstemming met gegevens wit tabel 3.5 .2 .2 , waruit blijkt dat afspraakspreekuren relatief meer voorkwamen in de onderzochte associatiepraktijken, waarin weer relatief meer patiënten met hogere opleidingen voorkwamen.

\subsubsection{VARIABELE 15: PRAKTIJKGROOTTE}

In onderstaande tabel wordt van de onderzochte praktijken met verschillende praktijkgroottes, het aantal praktijken en het percentage patiènten weergegeven.

Tabel 3.5.3.1. Aantal praktijken en percentage patiënten in de verschillende onderzochte praktijkgroottes.

\begin{tabular}{lcc}
\hline & $\begin{array}{c}\text { Praktijken } \\
\text { Aantal }\end{array}$ & $\begin{array}{c}\text { Patiënten } \\
\%\end{array}$ \\
\hline$>4000$ patiënten & 2 & 9 \\
3001 t.m. 4000 patiënten & 10 & 45 \\
2000 t.m. 3000 patiënten & 8 & 36 \\
$<2000$ patiënten & 2 & 10 \\
\hline Totaal & 22 & $100 \quad(\mathbf{N}=2064)$ \\
\hline
\end{tabular}

In de volgende tabel wordt van de verschillende praktijkgroottes de spreekuurvorm weergegeven. Hierbij zien we dat afspraakspreekuren relatief meer bij grotere praktijken ( $>3000$ patiënten) voorkwamen, en vrije spreekuren relatief meer bij kleinere praktijken. $(\leqslant 3000$ patiënten).

Tabel 3.5.3.2. Verband tussen de onderzochte praktijkgroottes en de spreekuurvorm.

\begin{tabular}{lccc}
\hline & $\begin{array}{c}\text { Afspraak- } \\
\text { spreekuur } \\
\text { Aantal }\end{array}$ & $\begin{array}{c}\text { Vrij } \\
\text { spreekuur } \\
\text { Aantal }\end{array}$ & $\begin{array}{c}\text { Totaal } \\
\text { Aantal }\end{array}$ \\
\hline$>4000$ patiënten & 2 & 0 & 2 \\
3001 t.m. 4000 patiënten & 9 & 1 & 10 \\
2000 t.m. 3000 patiënten & 4 & 4 & 8 \\
$<2000$ patiënten & 1 & 1 & 2 \\
\hline Totaal & 16 & 6 & 22 \\
\hline
\end{tabular}


Ten aanzien van leeftijd en geslacht van de patiënt waren hierbij geen verschillen aantoonbaar.

Patiënten met hogere opleidingen kwamen relatief meer voor in praktijken van $2000 \mathrm{t} . \mathrm{m} .3000$ patiënten, en relatief minder in praktijken met meer dan 4000 patiërten (Zie bijlage $\mathrm{II}$, tabel 3.5.3.3.).

\subsubsection{VARLABELE 16: LEEFTIJD HUISARTS}

In elf praktijken, met $51 \%$ van de onderzochte patiënten, was de leeftijd van de huisartsen jonger dan 40 jaar, en in eveneens elf praktijken, met $49 \%$ van de onderzochte patiënten, waren de huisartsen 40 jaar of ouder. De huisartsen waren dus wat deze variabele betreft, goed over de te onderzoeken praktijken verdeeld.

In onderstaande tabel wordt van de praktijken met jongere $(<40$ jr. $)$ en oudere $(\geqslant 40 \mathrm{jr}$.) huisartsen de spreekuurvorm weergegeven. Hierbij bleken beide spreekuurvormen zowel bij de jongere als oudere huisartsen in gelijke mate voor te komen.

Tabel 3.5.4.1. Verband tussen leeftijd huisarts en spreekuurvorm van de onderzochto praktijken.

\begin{tabular}{lccc}
\hline & $\begin{array}{c}\text { Afspraak- } \\
\text { spreekuur } \\
\text { Aantal }\end{array}$ & $\begin{array}{c}\text { Vrij } \\
\text { spreekuur } \\
\text { Aantal }\end{array}$ & $\begin{array}{c}\text { Totaal } \\
\text { Aantal }\end{array}$ \\
\hline Huisartsen $<40 \mathrm{jr}$. & 8 & 3 & 11 \\
Huisartsen $\geqslant 40 \mathrm{jr}$. & 8 & 3 & 11 \\
\hline Totaal & 16 & 6 & 22 \\
\hline
\end{tabular}

Ten aanzien van leeftijd en geslacht van de patiënt was tussen jongere en oudere huisartsen geen verschil aantoonbaar.

Wat het opleidingsniveau betreft bleek dat bij oudere huisartsen relatief meer patiënten met lagere opleidingen voorkwamen, en bij jongere huisartsen relatief meer patiënten met hogere opleidingen (Zie bijlage II, tabel 3.5.4.2.). 


\section{De toetsing van de hypothesen}

\subsection{INLEIDING}

In hoofdstuk I werden de hypothesen beschreven. Vervolgens kwam in hoofdstuk II de structuur van de verklarende variabelen aan de orde evenals de relatie met de hypothesen. In hoofdstuk III werd de populatie beschreven aan de hand van de variabelen. En in dit hoofdstuk komt de toetsing van de hypothesen aan de orde. De opbouw van dit hoofdstuk is als volgt. In de tweede paragraaf worden de hypothesen die betrekking hebben op kenmerken van de patiënt getoetst, waarna in de volgende paragraaf de toetsing plaatsvindt van de hypothesen betreffende kenmerken van de klacht. In de vierde paragraaf volgt de toetsing van de hypothesen die betrekking hebben op kenmerken van de huisarts en diens praktijk, waarna in de vijfde paragraaf tenslotte een korte samenvatting wordt gegeven.

\subsection{TOETSING HYPOTHESEN BETREFFENDE EIGENSCHAPPEN VAN DE PATIENT}

\subsubsection{HYP. 1. VROUWEN STELLEN LANGER UIT DAN MANNEN.}

Van alle mannelijke en vrouwelijke patiënten in de populatie werd de uitstelduur bepaald, waarbij rekening gehouden werd met leeftijd en opleiding van de patiënt, en met de aard van de klacht. Het verschil tussen de gemiddelden van beide populaties werd eenzijdig getoetst met de Kendall's Tau toets met een significantiedrempel van 0,1 . Hierbij bleek dat in de onderzochte populatie vrouwen langer uitstelden dan mannen (Zie bijlage II, tabel 4.2.1.1., uitgewerkt in figuur 2).

Zowel bij jongere als oudere patiënten bleek in de onderzoekpopulatie dat vrouwen langer uitstelden dan mannen (Zie bijlage II, tabel 4.2.1.2. en 4.2.1.3.).

Wat het opleidingsniveau van de patiënt betreft bleek dat bij patiënten 


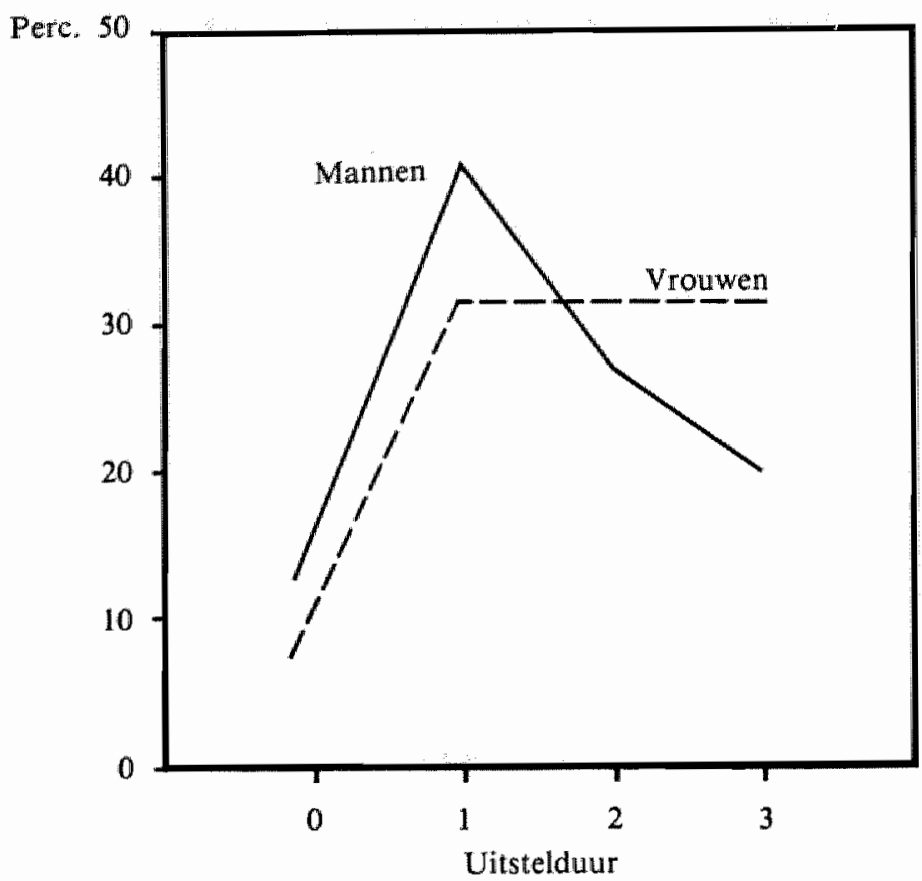

Fig. 2. Percentages manmen resp. vrouwen in relatie tot de uitsteldaur.

in de populatie met lagere en midden opleidingen, vrouwen langer uitstelden dan mannen (Zie bijlage II, tabel 4.2.1.4. en 4.2.1.5.). Bij patiënten met hogere opleidingen was hieromtrent geen verschil aantoonbaar. Ten aanzien van de aard van de klacht bleek dat bij:

- algemene klachten, buikklachten, klachten van het bewegingsapparaat en urogenitaalklachten, vrouwen in de populatie langer uitstelden dan mannen (Zie bijlage II, tabel 4.2.1.6., 4.2.1.7., 4.2.1.8. en 4.2.1.9.);

- sexualiteitsproblemen, geen uitspraak mogelijk was omdat in de populatie te weinig mannen met deze klacht voorkwamen;

- de overige klachtengroepen tussen mannen en vrouwen geen verschil in uitstelduur aantoonbaar was.

Conclusie: Zowel voor de totale populatie als ten aanzien van de onderzochte groepen jongeren en ouderen, patiënten met lagere en midden opleidingen bleek, dat vrouwen in de populatie langer uitstelden dan mannen. Ten aanzien yan de aard van de klacht bleek, dat de hypothese 
bevestigd werd bij algemene klachten, buikklachten, klachten van het bewegingsapparaat en urogenitaalklachten.

4.2.2. HYP. II. PATIENTEN OP OUDERE LEEFTIID ( $\geqslant 46$ JR.) STELLEN LANGER UIT DAN PATIENTEN OP JONGERE LEEFTIND (17 - 45 JR.).

Van de onderzochte jongere $(17-45 \mathrm{jr}$.) en oudere $(\geqslant 46 \mathrm{jr}$.) patiënten werd de uitstelduur bepaald, waarbij rekening gehouden werd met geslacht en opleiding van de patiënt, en met de aard van de klacht. Het verschil tussen de gemiddelden van de onderzochte jongere en oudere patiënten werd eenzijdig getoetst met de Kendall's Tau toets met een significantiedrempel van 0,1 . Hierbij bleek dat oudere patiënten in de populatie langer uitstelden dan jongere patiënten (Zie bijlage II, tabel 4.2.2.1., uitgewerkt in figuur 3 ).

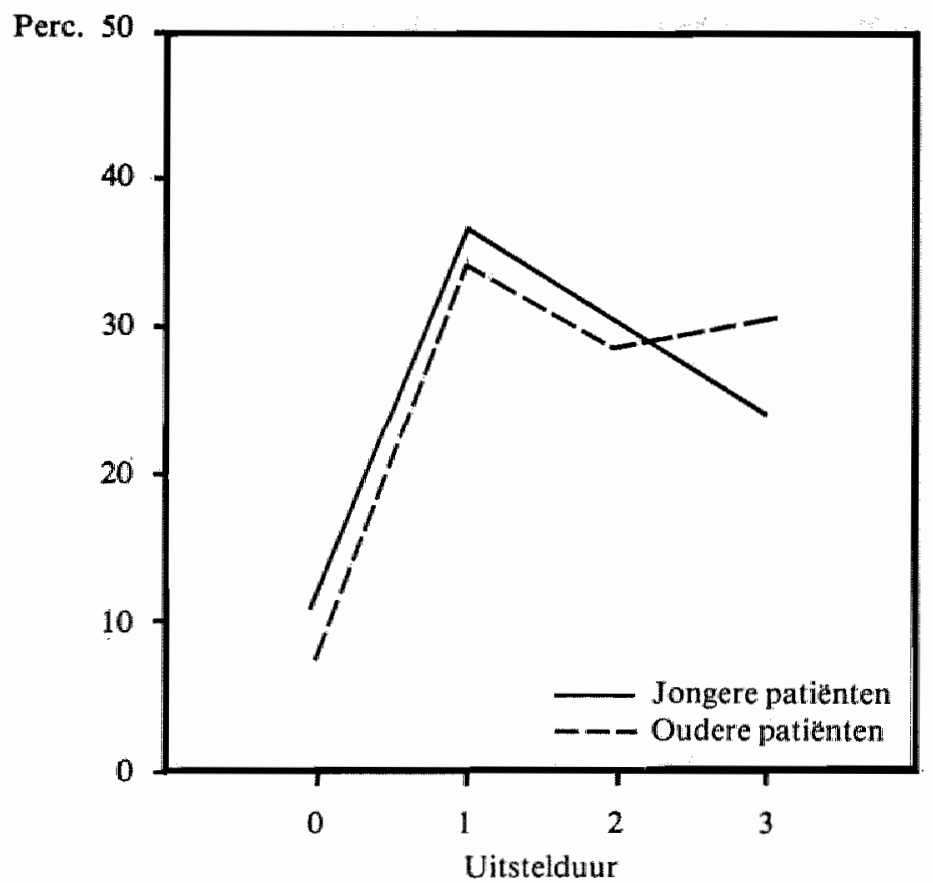

Fig. 3. Percentages jongere resp. oudere patiënten in relatie tot de uilsteldur. 
Ten aanzien van het geslacht bleek dat oudere mannen in de populatie langer uitstelden dan jongere mannen (Zie bijlage II, tabel 4.2.2.2.). Tussen de onderzochte jongere en oudere vrouwen was geen verschil in uitstelduur aantoonbaar.

Ten aanzien yan patiënten met lagere en hogere opleidingen stelden ouderen langer uit dan jongeren (Zie bijlage II, tabel 4.2.2.3. en 4.2.2.4.). Bij patiënten met midden opleidingen was hieromtrent geen verschil in uitstelduur aantoonbaar.

Ten aanzien wan de aard van de klacht bleek dat bij:

- algemene klachten, klachten van het bewegingsapparaat, en ,k.n.o.klachten of klachten van de luchtwegem', oudere patiënten in de populatie langer uitstelden dan jongere patiënten (Zie bijlage II, tabel 4.2.2.5., 4.2.2.6. en 4.2.2.7.);

-- sexualiteitsproblemen geen uitspraak mogelijk was omdat slechts 7 ouderen een dergelijke klacht presenteerden;

- de overige klachtengroepen, tussen jongeren en ouderen geen verschil aantoonbaar was.

Conclusie: Zowel ten aanzien van de totale populatie als ten aanzien van mannen was de hypothese aantoonbaar. Ten aanzien van de aard van de klacht bleek de hypothese aantoonbaar te zijn bij algemene klachten, klachten van het bewegingsapparaat en ,k.n.o.-klachten of klachten van de luchtwegen'.

\subsubsection{HYP. III. PATIENTEN MET LAGERE OPLEIDINGEN STELLEN LANGER UIT DAN PATIENTEN MET HOGERE OPLEIDINGEN.}

Van patiënten in de populatie met zowel lagere, midden als hogere opleidingen werd de uitstelduur bepaald, waarbij rekening gehouden werd met leeftijd en geslacht van de patiënt, en met de aard van de klacht. Het verschil tussen de gemiddelden van de drie populaties werd eenzijdig getoetst met de Kendall's Tau toets met een significantiedrempel van 0,1 . Hierbij bleek dat in de populatie patiënten met hogere opleidingen langer uitstelden dan patiënten met lagere opleidingen (Zie bijlage II, tabel 4.2.3.1., uitgewerkt in figuur 4). De verkregen gegevens waren niet in overeenstemming met de hypothese.

Ten aanzien van de leeftijd van de patiënt bleek dat jongere patiënten met hogere opleidingen in de populatie langer uitstelden dan jongere patiënten met lagere opleidingen (Zie bijlage II, tabel 4.2.3.2.). Bij 


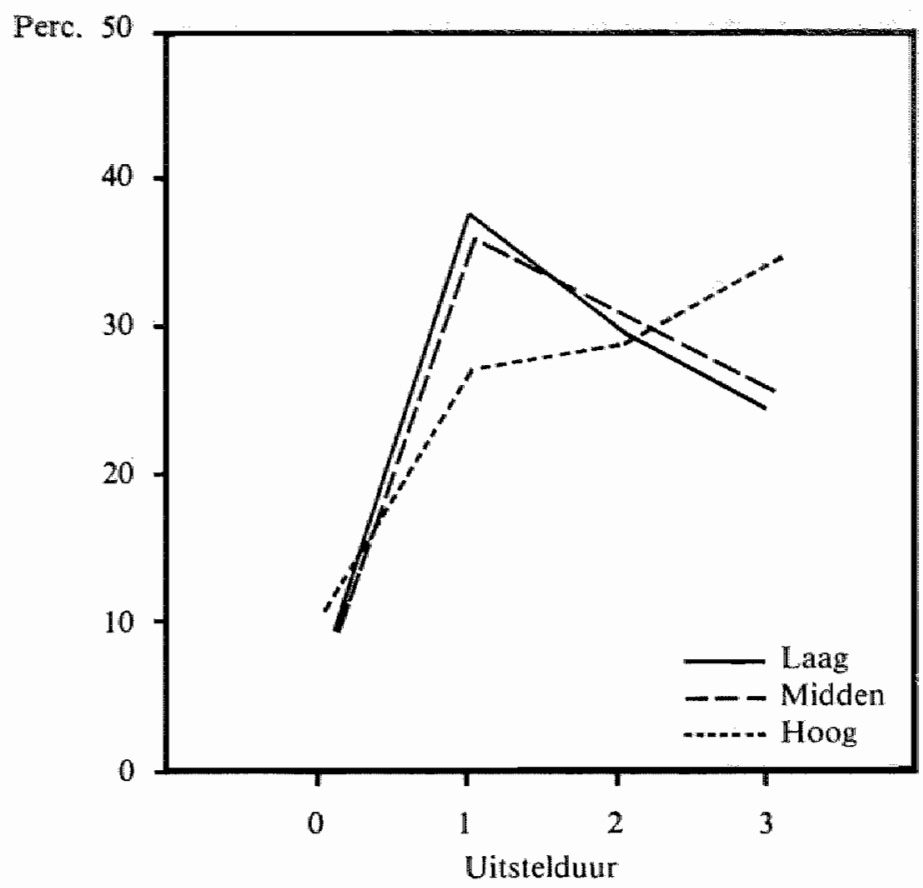

Fig. 4. Percentages patiènten met verschillende opleidingsniveaw"s in relatie tot de witstelduur.

oudere patiënten bleek ten aanzien van het opleïdingsniveau geen verschil in uitstelduur aantoonbaar te zijn.

Wat het geslacht betreft bleek dat vrouwen met hogere opleidingen in de populatie langer uitstelden dan vrouwen met lagere opleidingen (Zie bijlage II, tabel 4.2.3.3.). Mannen vertoonden ten aanzien van het opleidingsniveau geen verschil in uitstelduur.

Ten aanzien van de aard van de klacht bleek dat bij:

- algemene klachten, hartklachten, k.n.o.-klachten en klachten van de luchtwegen, patiënten met hogere opleidingen in de populatie langer uitstelden dan patiënten met lagere opleidingen (Zie bijlage II, tabel 4.2.3.4., 4.2.3.5. en 4.2.3.6.);

- alle overige klachtengroepen geen verschil in vitstelduur tussen patiënten met verschillende opleidingsniveau's aantoonbaar was.

Conclusie: Zowel ten aanzien van jongeren en vrouwen, als ten aanzien van de aard van de klacht bij algemene klachten, hartklachten, k.n.o.- 
klachten en klachten van de luchtwegen bleek, dat patiënten met hogere opleidingen langer uitstelden dan patiënten met lagere opleidingen.

De verkregen gegevens waren niet in overeenstemming met de hypothese.

\subsubsection{HYP. IV. PATIENTEN DIE HUN HUISARTS FREQUENT CONSUL- TEREN, VERTONEN GEEN VERSCHIL IN UTTSTELDUUR TEN OPZICHTE VAN PATIENTEN, DIE HUN HUISARTS MINDER FREQUENT CONSULTEREN.}

Deze hypothese veronderstelt dat patiënten die hun huisarts frequent consulteren, enerzijds niet langer en anderzijds niet korter uitstellen, dan patiënten die hun huisarts minder frequent consulteren.

Van patiënten in de populatie die hun huisarts weinig, normaal of vaak consulteerden werd de uitstelduur bepaald, waarbij rekening gehouden werd met leeftijd, geslacht en opleiding van de patiënt, en met de aard van de klacht. Het verschil tussen de gemiddelden van deze drie populaties werd tweezijdig getoetst met de Kendall's Tau toets met een significantiedrempel van $5 \%$. Hierbij bleek dat tussen de onderzochte patiënten met verschillende consultfrequenties geen verschil in uitstelduur aantoonbaar was.

Bij oudere patiënten bleek dat patiënten in de populatie die weinig consulteerden langer uitstelden dan patiënten die vaker consulteerden (Zie bijlage II, tabel 4.2.4.1.). Jongere patiënten in de populatie vertoonden hieromtrent geen verschil in uitstelduur.

Ten aanzien van het geslacht was met betrekking tot de consultfrequenties geen verschil in uitstelduur aantoonbaar.

Wat het opleidingsniveau betreft bleek dat bij patiënten met een hogere opleiding, de onderzochte patiënten die weinig consulteerden langer uitstelden dan de patiënten die vaker consulteerden (Zie bijlage II, tabel 4.2.4.2.). Bij beide overige opleidingsniveau's was hieromtrent geen verschil in uitstelduur aantoonbaar.

Ten aanzien van de aard van de klacht bleek dat bij:

- hartklachten, gezwellen en ,algemene klachten, huidklachten of klachten op sexualiteitsgebied", patiënten in de populatie die weinig consulteerden langer uitstelden dan patiënten die vaker consulteerden (Zie bijlage II, tabel 4.2.4.3., 4.2.4.4. en 4.2.4.5.);

- buikklachten, patiënten in de populatie die vaker consulteerden langer uitstelden dan patiënten die minder vaak consulteerden (Zie bijlage III, tabel 4.2.4.6.);

- de overige klachtengroepen, ten aanzien van de consultfrequenties geen verschil in uitstelduur aantoonbaar was. 
Conclusie: Bij de grote meerderheid van de onderzoekpopulatie bleken de gegevens in overeenstemming te zijn met de hypothese. We zien dat in de groepen jongeren, vrouwen, mannen en patiènten met lagere en midden opleidingen, tussen patiënten met verschillende consultfrequenties geen verschil in uitstelduur aantoonbaar was. Wat de klachten betreft zien we dat eveneens geen verschil in uitstelduur aantoonbaar was bij urogenitaalklachten, gezwellen, klachten van het bewegingsapparaat, en ,k.n.o.-klachten of klachten van de luchtwegen?.

\subsubsection{HYP. V. PATIENTEN IN PLATTELANDSPRAKTIJKEN STELLEN LANGER UIT DAN PATIENTEN IN STADSPRAKTIJKEN,}

De onderzoekpopulatie werd ingedeeld in stads- en plattelandspatiënten, al naar gelang de patiënten ingeschreven waren in stads- of plattelandspraktijken (zie pagina 37). Van beide populaties werd de uitstelduur bepaald, waarbij rekening gehouden werd met leeftijd, geslacht en opleiding van de patiënt, en met de aard van de kllacht. Het verschil tussen

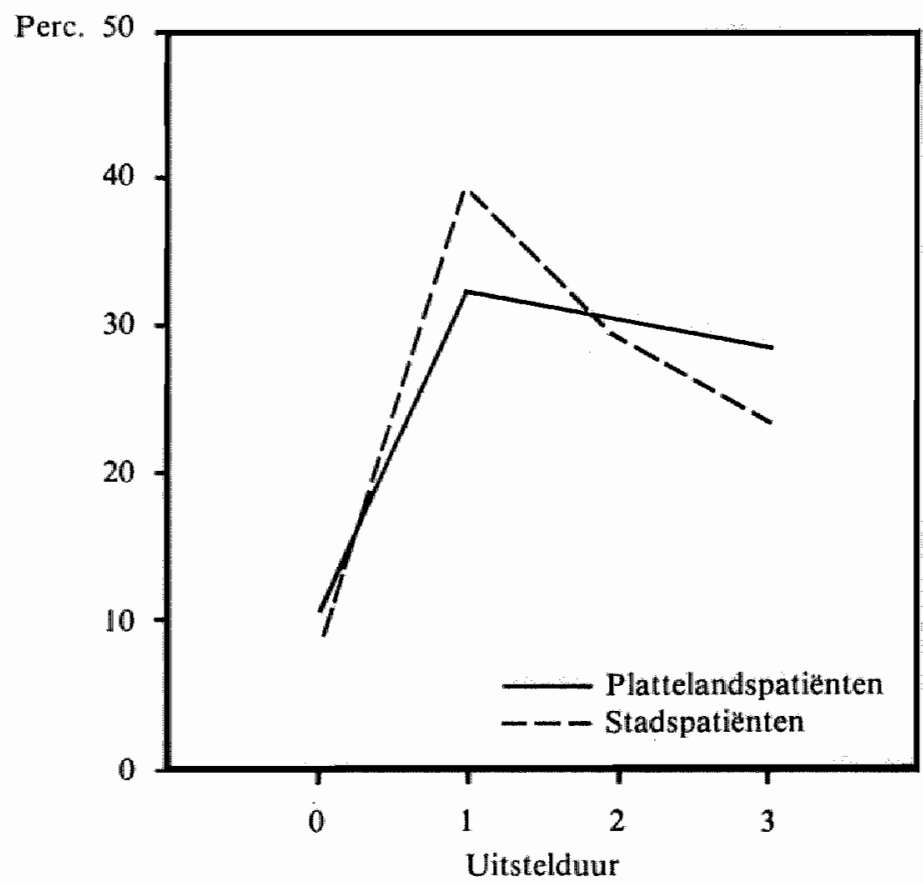

Fig. 5. Percentages patiënten in stads- en plattelandspraktijken in relatie rot de uitstelduur. 
de gemiddelden van beide populaties werd eenzijdig getoetst met de Kendall"s Tau toets met een significantiedrempel wan 0,1 . Hierbij bleek dat patiënten in plattelandspraktijken langer uitstelden dan in stadspraktijken (Zie bijlage II, tabel 4.2.5.1., uitgewerkt in figuur 5). Dit was zowel bij jongere als oudere patiënten aantoonbaar (Zie bijlage II, tabel 4.2.5.2. en 4.2.5.3.).

Ten aanzien van het geslacht bleek dat vrouwen in plattelandspraktijken langer uitstelden dan in stadspraktijken (Zie bijlage $\Pi$, tabel 4.2.5.4.). Wat het opleidingsniveau betreft bleek dat patiënten met lagere opleidingen, in plattelandspraktijken langer uitstelden dan in stadspraktijken (Zie bijlage II, tabel 4.2.5.5.).

Ten aanzien van de aard van de klacht bleek dat bij:

- k.n.o.-klachten, hartklachten, urogenitaalklachten en klachten op sexualiteitsgebied, patiënten in plattelandspraktijken langer uitstelden dan in stadspraktijken (Zie bijlage II, tabel 4.2.5.6., 4.2.5.7., 4.2.5.8. en 4.2.5.9.).

- de overige klachtengroepen tussen patiënten in stads- en plattelandspraktijken geen verschil in uitstelduur aantoonbaar was.

Conclusie: Zowel ten aanzien van de totale populatie als ten aanzien van de onderzochte groepen jongeren, ouderen, vrouwen en patiënten met lagere opleidingen bleek, dat patiënten in plattelandspraktijken langer uitstelden dan in stadspraktijken. Ten aanzien van de aard van de klacht bleek dat bij klachten op sexualiteitsgebied, hartklachten, urogenitaalklachten en k.n.o.-klachten, patiënten in plattelandspraktijken langer uitstelden dan in stadspraktijken.

In het merendeel van de onderzoekpopulatie was de hypothese aantoonbaar.

4.2.6. HYP. VI. PATIENTEN DIE MEER ERVARING HEBBEN MET DE KLACHT; IN DIE ZIN DAT ZIJ DE KLACHT AL EERDER HEBBEN GEHAD EVENTUEEL DAARVOOR ZIJN BEHANDELD, ZULLEN BII ERNSTIGE KLACHTEN KORTER ENN BIJ MINDER ERNSTIGE KLACHTEN LANGER UITSTELLEN.

Op pagina 18 staat beschreven hoe een rangorde van klachten verkregen werd, al naar gelang de geschatte ernst van de klacht. De klachten werden door middel van een kwartielindeling ingedeeld in 3 groepen: 


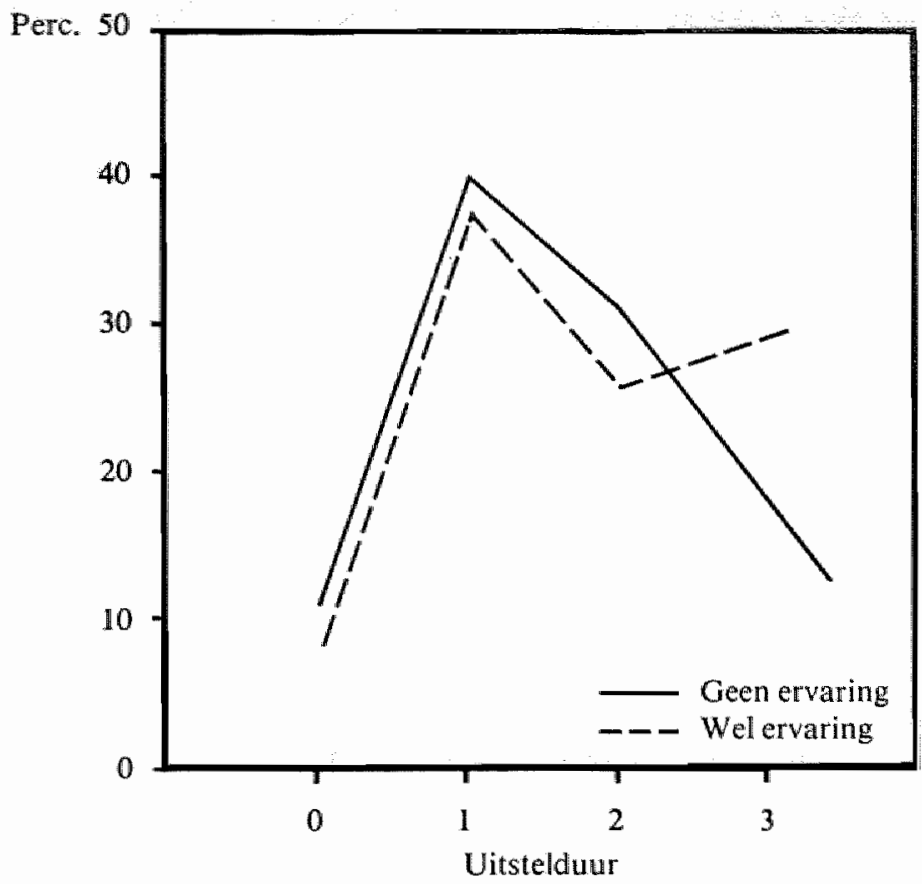

Fig. 6. Percentages patiënten met minder ernstige klachten, die wel resp. geen ervaring hebben met de klacht, in relatie tot de uitstelduur.

a. De 11 meest ernstige klachten.

b. De 18 minder ernstige klachten.

c. De 11 minst ernstige klachten.

Van elk van deze drie groepen werd van patiënten, die wèl en géén ervaring hadden met de klacht, de uitstelduur bepaald, waarbij rekening gehouden werd met leeftijd, gesllacht en opleiding van de patiënt. Het verschil tussen de gemiddelden van beide populaties, die wel en geen ervaring hadden met de klacht, werd eenzijdig getoetst met de Kendall's Tau toets met een significantiedrempel van 0,1 . Hierbij bleek dat in de groepen met de 18 minder ernstige klachten en met de 11 minst ernstige klachten, de patiënten die wèl ervaring hadden met de klacht langer uitstelden dan de patiënten die géén ervaring hadden met de klacht (Zie bijlage II, tabel 4.2.6.1., uitgewerkt in figuur 6, en tabel 4.2.6.2., uitgewerkt in figuur 7 ).

Ten aanzien van de leeftijd van de patiënt bleek dat jongere patiënten met minst ernstige klachten, bij ervaring met de klacht langer uitstelden 
dan indien zij géén ervaring hadden met de klacht (Zie bijlage II, tabel 4.2.6.3.). Bij oudere patiënten bleek dat patiënten met minder en minst ernstige klachten, bij ervaring met de klacht langer uitstelden dan indien zij géén ervaring hadden met de klacht (Zie bijlage II, tabel 4.2.6.4. en 4.2.6.5.).

Bij vrouwen bleek dat de onderzochte vrouwen met minder ernstige klachten, bij ervaring met de klacht langer uitstelden dan indien zij géén ervaring hadden met de klacht (Zie bijlage II, tabel 4.2.6.6.). Bij mannen bleek dat mannen met minder en minst ernstige klachten, bij ervaring met de klacht langer uitstelden dan indien zij géén ervaring hadden met de klacht (Zie bijlage II, tabel 4.2.6.7. en 4.2.6.8.).

Wat het opleidingsniveau betreft bleek dat bij patiënten met:

- lagere opleidingen, patiënten in de populatie met de meest ernstige en minder ernstige klachten, bij ervaring met de klacht langer uitstelden dan indien zij géén ervaring hadden met de klacht (Zie bijlage II, tabel 4.2.6.9. en 4.2.6.10.);

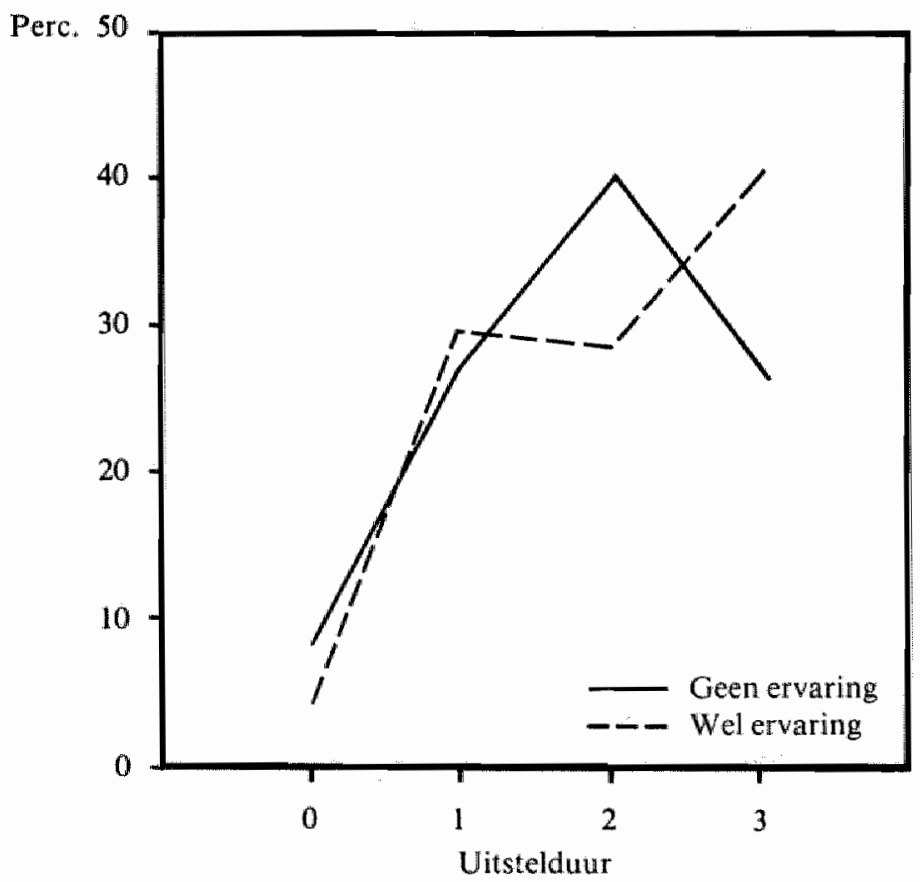

Fig. 7. Percentages patiêntem met de minst ernstige klachten, die wel resp. geen erwaring hebben met de klacht, in relatie tot de uitstelduur. 
- midden opleidingen, patiënten in de populatie met minst ernstige klachten, indien zij ervaring hadden met de klacht langer vitstelden dan indien zij géén ervaring hadden met de klacht (Zie bijlage II, tabel 4.2.6.11.);

- hogere opleidingen, patiënten in de populatie met minder en minst ernstige klachten, bij ervaring met de klacht langer uitstelden dan indien zij géén ervaring hadden met de klacht (Zie bijlage II, tabel 4.2.6.12. en 4.2.6.13.).

Conclusie: Bij niet ernstige klachten was de hypothese zowel ten aanzien van de totale populatie als ten aanzien van de onderzochte groepen jongeren en ouderen, mannen en vrouwen, patiënten met midden en hogere opleidingen aantoonbaar. $\mathrm{Bij}$ ernstige klachten bleek tussen patiënten, die wèl en géen ervaring hadden met de klacht, geen verschil in uitstelduur aantoonbaar te zijn.

\subsection{TOETSING HYPOTHESEN BETREFFENDE EIGENSCHAPPEN VAN DE KLACHT}

4.3.1. HYP. VII. BIJ KLACHTEN, DIE ALGEMEEN BEKEND STAAN ALS MOGELIJKE AANWIJZINGEN VOOR EEN ERNSTIGE ZIEKTE, STELLEN PATIËNTEN KORTER UIT.

Op pagina 41 en 42 werd beschreven hoe de klachten ingedeeld werden in 11 meest ernstige, 18 minder ernstige en 11 minst ernstige klachten. Van elk van deze groepen werd de uitstelduur bepaald, waarbij rekening gehouden werd met leeftijd, geslacht en opleiding van de patiënt. Het verschil tussen de gemiddelden van deze drie populaties, ieder met een verschillende mate van ernst van de klacht, werd eenzijdig getoetst met de Kendall's Tau toets met een significantiedrempel van 0,1 . Hierbij bleek dat patiënten in de populatie met de 11 meest ernstige klachten gemiddeld korter uitstelden dan patiënten in de populatie met de 11 minst ernstige klachten (Zie bijlage II, tabel 4.3.1.1., uitgewerkt in figuur 8).

Zowel ten aanzien van jongeren en ouderen als ten aanzien van mannen en vrouwen bleek, dat patiënten in de populatie met minder ernstige klachten langer uitstelden dan patiënten met meer ernstige klachten (Zie bijlage II, tabel 4.3.1.2., 4.3.1.3., 4.3.1.4. en 4.3.1.5.).

Wat het opleidingsniveau betreft bleek bij patiënten met lagere en midden opleidingen, dat patiënten in de populatie met minder ernstige klachten langer uitstelden dan patiënten met meer ernstige klachten (Zie 


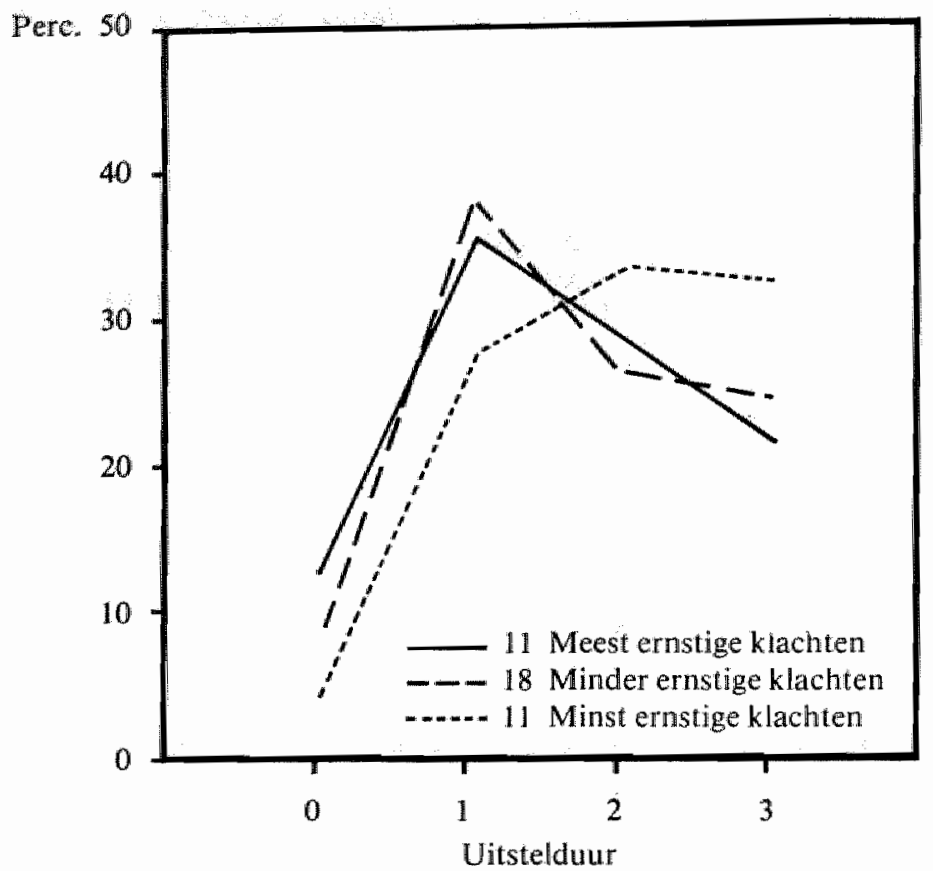

Fig. 8. Percentages patiënten met verschillende graden van ernst van de klacht in relatie to de uitsteldaur.

bijlage II, tabel 4.3.1.6. en 4.3.1.7.). Patiënten met hogere opleidingen vertoonden hieromtrent geen verschil in uitstelduur.

Conclusie: De gevonden gegevens waren in overeenstemning met de hypothese. Zowel ten aanzien van de totale populatie als ten aanzien van de onderzochte groepen jongeren en ouderen, mannen en vrouwen, patiënten met lagere en midden opleidingen werd de hypothese bevestigd.

\subsubsection{HYP. VIII, BIJ KLACHTENPATRONEN MET PIIN VERTOONT DE PATTENT EEN KORTERE UITSTELDUUR DAN BIJ OVEREENKOMSTIGE KLACHTENPATRONEN ZONDER PIJN.}

Zesentwintig procent van de onderzochte patiënten gaf pijn op als voornaamste reden van komst naar de dokter. Zowel van patiënten die pijn opgaven als reden van komst naar de dokter en van patiënten met 
klachtenpatronen, gepaard gaande mèt pijn, als wan alle overige onderzochte patiënten werd de uitstelduur bepaald, waarbij rekening gehouden werd met leeftijd, geslacht en opleiding van de patiënt, en met de aard van de klacht. Het verschil tussen de gemiddelden van beide populaties werd eenzijdig getoetst met de Kendall's Tau toets met een significantiedrempel van 0,1 . Hierbij bleek dat patiënten in de populatie bij klachtenpatronen gepaard gaande mèt pijn, gemiddeld korter uitstelden dan patiënten bij klachtenpatronen zònder pijn (Zie bijlage II, tabel 4.3.2.1, uitgewerkt in figuur 9).

Zowel ten aanzien van jongeren en ouderen als ten aanzien van mannen en vrouwen bleek, dat patiënten in de populatie bij klachtenpatronen mèt pijn korter uitstelden dan patiënten bij klachtenpatronen zònder pijn (Zie bijlage II, tabel 4.3.2.2., 4.3.2.3., 4.3.2.4. en 4.3.2.5.).

Wat het opleidingsniveau betreft bleek dat zowel bij patiënten met lagere als midden als hogere opleidingen, patiënten in de populatie bij klachten-

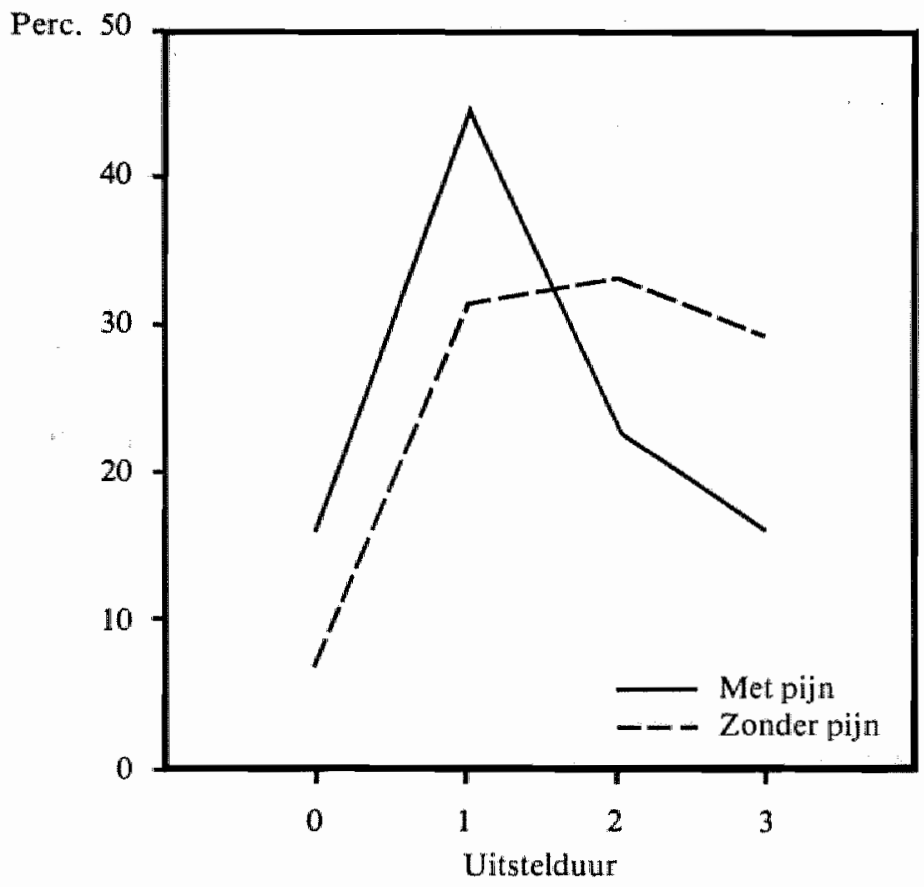

Fig. 9. Percentages patiënten bij klachtenpatronen mèt resp. zònder pijn in relatic tot de uitstelduar. 
patronen mè̀ pijn korter uitstelden dan patiënten bij klachtenpatronen zònder pijn (Zie bijlage II, tabel 4.3.2.6., 4.3.2.7. en 4.3.2.8.).

Ten aanzien van de aard van de klacht bleek dat bij:

- algemene klachten, k.n.o.-klachten, hartklachten, urogenitaalklachten en klachten van het bewegingsapparaat, patiënten in de populatie bij klachtenpatronen mèt pijn korter uitstelden dan patiënten bij klachtenpatronen zònder pijn (Zie bijlage II, tabel 4.3.2.9., 4.3.2.10., 4.3.2.11., 4.3.2.12. en 4.3.2.13.);

- klachten van de luchtwegen, buikklachten, sexualiteitsproblemen, gezwellen en huidklachten, tussen patiënten bij klachtenpatronen al of niet gepaard gaande met pijn, geen verschil in uitstelduur aantoonbaar was.

Conclusie: De gevonden gegevens waren zowel voor de totale populatie als voor de onderzochte groepen jongeren en ouderen, mannen en vrouwen, patiënten met lagere, midden en hogere opleidingen, in overeenstemming met de hypothese. Ten aanzien van de aard van de klacht bleek dat bij algemene klachten, k.n.o.-klachten, hartklachten, urogenitaalklachten en klachten van het bewegingsapparaat, de hypothese eveneens bevestigd werd.

\subsubsection{HYP. IX. BIJ KLACHTEN, TEN AANZIEN WAARVAN HET PSYCHISCHE ASPECT OVERHEERST, ZULLEN DE PATIENTEN LANGER UITSTELLEN.}

De klachten werden in dit onderzoek door de huisarts beoordeeld als zijnde overwegend somatisch, psycho-somatisch, psychisch of maatschappelijk. Van de patiënten met overwegend somatische resp. psychische klachten werd de uitstelduur bepaald, waarbij rekening gehouden werd met leeftijd, geslacht en opleiding van de patiënt, en met de aard van de klacht. Het verschil tussen de populatiegemiddelden van bovenstaande karakterkenmerken van de klacht werd eenzijdig getoetst met de Kendall's Tau toets met een significantiedrempel van 0,1 . Hierbij bleek dat patiënten in de populatie met overwegend psychische klachten langer uitstelden dan patiënten met overwegend somatische klachten (Zie bijlage II, tabel 4.3.3.1., uitgewerkt in figuur 10).

Zowel ten aanzien van jongeren en ouderen als ten aanzien van mannen en vrouwen bleek, dat patiënten in de populatie met overwegend psychische klachten langer uitstelden dan patiënten met overwegend somatische klachten (Zie bijlage II, tabel 4.3.3.2., 4.3.3.3., 4.3.3.4. en 4.3.3.5.). 


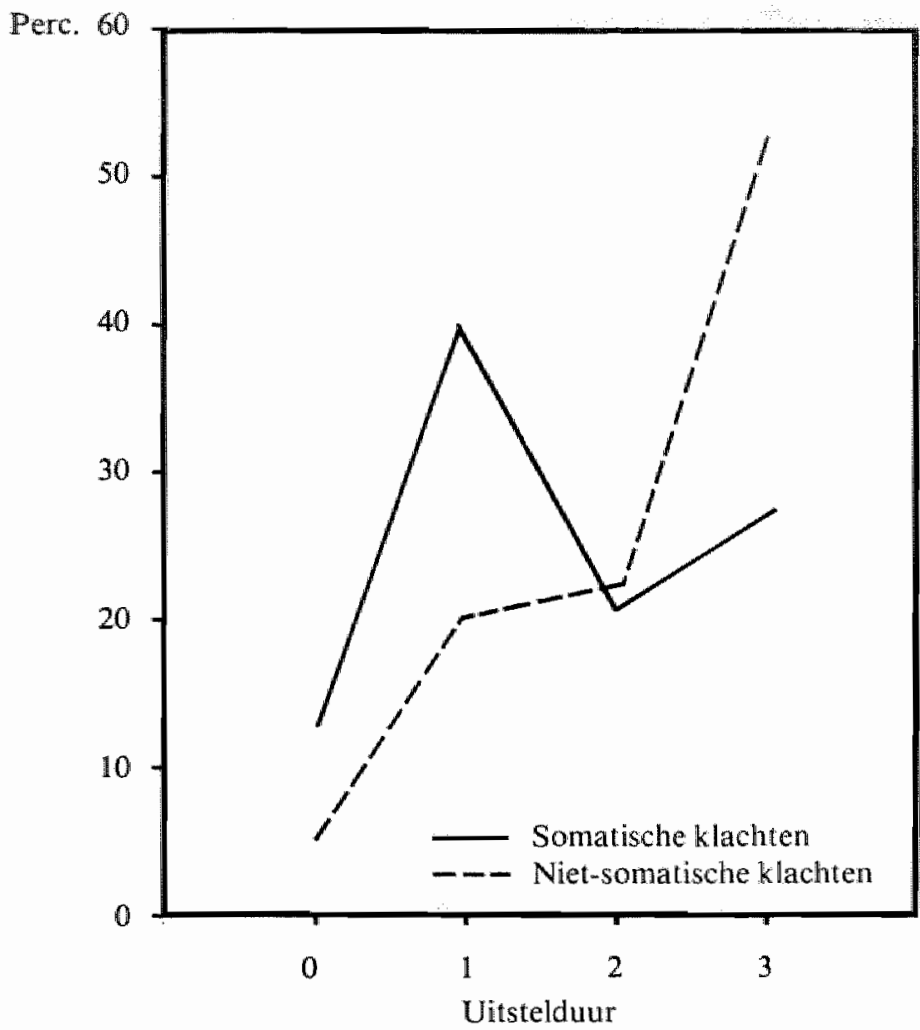

Fig. 10. Percentages patiënten net overwegend somatische resp. psychische klachten in relatie tot de uitstelduur.

Wat het opleidingsniveau betreft bleek dat bij patiënten in de populatie met lagere, mídden en hogere opleidingen, patiënten met overwegend psychische klachten langer uitstelden dan patiënten met overwegend somatische klachten (Zie bijlage II, tabel 4.3.3.6., 4.3.3.7. en 4.3.3.8.). Ten aanzien van de aard van de klacht bleek dat bij:

- buikklachten, klachten van het bewegingsapparaat, ,k.n.o.-klachten of klachten van de luchtwegen', ,algemene klachten, huidklachten of klachten op sexualiteitsgebied', patiënten met overwegend psychische klachten in de populatie langer uitstelden dan patiënten met overwegend somatische klachten (Zie bijlage II, tabel 4.3.3.9., 4.3.3.10., 4.3.3.11. en 4.3.3.12.);

- hartklachten, urogenitaalklachten en gezwellen, tussen patiënten met 
overwegend psychische klachten en overwegend somatische klachten geen verschil in uitstelduur aantoonbaar was.

Conclusie: Zowel ten aanzien van de totale populatie als ten aanzien van de onderzochte groepen jongeren en ouderen, mannen en vrouwen, patiënten met lagere, midden en hogere opleidingen, werd de hypothese bevestigd. Wat de aard van de klacht betreft bleek dat bij buikklachten, klachten van het bewegingsapparaat, ,k.n.o--klachten of klachten van de luchtwegen', ,algemene klachten, huidklachten of klachten op sexualiteitsgebied', de gevonden gegevens eveneens in overeenstemming waren met de hypothese.

\subsection{TOETSING HYPOTHESEN BETREFFENDE EIGENSCHAPPEN VAN DE HUISARTS EN ZIJN PRAKTIJK}

\subsubsection{HYP. X. BII HUISARTSEN DIE IN HUN PRAKTIJK RELATIEF MEER KLACHTEN ALS PSYCHISCH AANGEVEN, STELLEN PATTENTEN LANGER UIT DAN BIJ HUISARTSEN DIE DIT IN MINDERE MATE DOEN.}

De in dit onderzoek voorkomende klachten werden door de deelnemende huisartsen voor gemiddeld $68 \%$ beschouwd als overwegend somatisch, en voor gemiddeld $32 \%$ beschouwd als overwegend psycho-somatisch, psychisch of maatschappelijk van aard.

Voor onderstaande toetsing werden de aan dit onderzoek deelnemende huisartsen ingedeeld in drie groepen:

a. Huisartsen die $80 \%$ of meer, somatische klachten in hun praktijk aangaven. Dit werd gedaan door 4 van de 22 huisartsen. Deze 4 huisartsen onderzochten 395 patiënten $(=19 \%$ van de totale onderzoekpopulatie).

b. Huisartsen die $40 \%$ of meer, psychische klachten in hun praktijk aangaven. Dit werd gedaan door 3 van de 22 huisartsen. Deze 3 huisartsen onderzochten 295 patiënten $(=14 \%$ van de totale onderzoekpopulatie).

c. Alle overige deelnemende huissartsen. Deze onderzochten 1380 patiënten $(=67 \%$ wan de totale onderzoekpopulatie).

Van de patiënten in bovenstaande drie groepen werd de uitstelduur bepaald, waarbij rekening gehouden werd met leeftijd, geslacht en opleiding van de patiënt, en met de aard van de klacht. Het verschil tussen de gemiddelden van deze drie populaties werd eenzijdig getoetst met de Kendall's Tau toets met een significantiedrempel van 0,1 . Hierbij bleek 


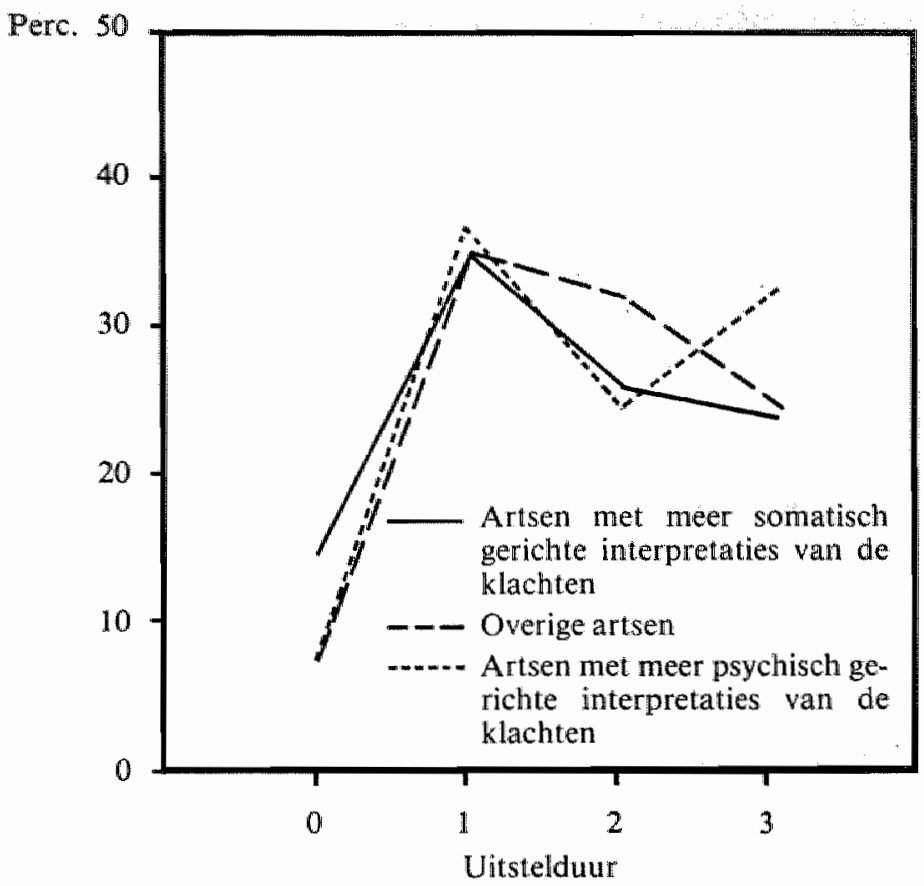

Fig. 11. Percentages patiënten bij artsen met relatief meer somatisch resp. meer psychisch gerichte interpretaties van de klachten in relatie tor de aitstelduur.

dat patiënten in de populatie bij artsen die meer psychische klachten aangaven langer uitstelden, dan bij artsen die dit in mindere mate deden (Zie bijlage II, tabel 4.4.1.1., uitgewerkt in figuur 11).

Zowel ten aanzien van jongeren en ouderen als ten aanzien van mannen en vrouwen bleek, dat patiënten in de populatie bij artsen die meer psychische klachten aangaven langer witstelden dan bij artsen die dit in mindere mate deden (Zie bijlage II, tabel 4.4.1.2., 4.4.1.3., 4.4.1.4. en 4.4.1.5.).

Wat het opleidingsniveau betreft bleek dat zowel bij patiënten met lagere als midden als hogere opleidingen, patiënten in de populatie bij artsen die meer psychische klachten aangaven langer uitstelden dan bij artsen die dit in mindere mate deden (Zie bijlage II., tabel 4.4.1.6., 4.4.1.7. en 4.4.1.8.).

Ten aanzien van de aard van de klacht bleek dat bij: 
- klachten van de luchtwegen en hartklachten, patiënten bij artsen die meer psychische klachten aangaven langer uitstelden dan bij artsen die dit in mindere mate deden (Zie bijlage II, tabel 4.4.1.9. en 4.4.1.10.);

- alle overige klachtengroepen hieromtrent geen verschil in uitstelduur aantoonbaar was.

Conclusie: Zowel ten aanzien van de totale populatie als ten aanzien van de onderzochte groepen jongeren en ouderen, mannen en vrouwen, patiënten met lagere, midden en hogere opleidingen, waren de gevonden gegevens in overeenstemming met de hypothese. Ten aanzien van de aard van de klacht was bij hartklachten en klachten van de luchtwegen, de hypothese eveneens aantoonbaar.

\subsubsection{HYP. XI. IN ASSOCIATIEPRAKTIJKEN STELLEN PATIENTEN LANGER UIT DAN IN SOLOPRAKTIJKEN.}

Onder een associatie werd verstaan een samenwerkingsverband tussen twee artsen, waarbij de praktijk voor gemeenschappelijke rekening wordt uitgeoefend. Van de in het onderzoek aanwezige 15 solopraktijken en 7 associatiepraktijken werd van de patiënten de uitstelduur bepaald, waarbij rekening gehouden werd met leeftijd, geslacht en opleiding van de patiënt, en met de aard van de klacht. Het verschil tussen de gemiddelden van beide populaties werd eenzijdig getoetst met de Kendall's Tau toets met een significantiedrempel van 0,1 . Hierbij bleek tussen patiënten in de onderzochte associatie- en solopraktijken geen verschil in uitstelduur aantoonbaar te zijn.

Ten aanzien van de leeftijd bleek dat jongere patiënten in de populatie in associatiepraktijken langer uitstelden dan in solopraktijken (Zie bijlage II, tabel 4.4.2.1.). Oudere patiënten bleken in de populatie in solopraktijken langer uit te stellen dan in associatiepraktijken (Zie bijlage II, tabel 4.4.2.2.). Ten aanzien van het geslacht bleek tussen associatie- en solopraktijken bij mannen en vrouwen geen verschil in uitstelduur aantoonbaar te zijn.

Wat het opleidingsniveau betreft bleek dat bij lagere opleidingen de onderzochte patiënten in solopraktijken langer uitstelden dan in associatiepraktijken (Zie bijlage II, tabel 4.4.2.3.). Ten aanzien van midden en hogere opleidingen bleek dat de onderzochte patiënten in associatiepraktijken langer uitstelden dan in solopraktijken (Zie bijlage II, tabel 4.4.2.4. en 4.4.2.5.). 
Ten aanzien van de aard van de klacht bleek dat bij:

- k.n.o.-klachten, klachten van het bewegingsapparaat en klachten op sexualiteitsgebied, de onderzochte patiënten in associatiepraktijken langer uitstelden dan in solopraktijken (Zie bijlage II, tabel 4.4.2.6., 4.4.2.9. en 4.4.2.10.);

- hartklachten en klachten van de luchtwegen, de onderzochte patiënten in solopraktijken langer uitstelden dan in associatiepraktijken (Zie bijlage II, tabel 4.4.2.7. en 4.4.2.8.);

- algemene klachten, buikklachten, urogenitaalklachten, gezwellen en huidklachten, hieromtrent geen verschil in uitstelduur aantoonbaar was.

Conclusie: Enerzijds bleek ten aanzien van de onderzochte groepen jongeren en patiënten met midden en hogere opleidingen, en ten aanzien van de klacht bij k.n.o.-klachten, klachten van het bewegingsapparaat en klachten op sexualiteitsgebied, dat patiënten in associatiepraktijken langer uitstelden. Anderzijds bleek ten aanzien van de onderzochte groepen ouderen en patiënten met lagere opleidingen, en ten aanzien van de klacht bij hartklachten en klachten van de luchtwegen, dat patiënten in solopraktijken langer uitstelden.

In zijn totaliteit was de hypothese niet aantoonbaar.

4.4.3. HYP. XII. IN PRAKTIJKEN MET, UITSLUITEND' AFSPRAAKSPREEKUUR STELLEN PATIENTEN LANGER UIT DAN IN PRAKTIJKEN MET, UITSLUITEND' VRIJ SPREEKUUR.

Van de patiënten in de 6 onderzochte praktijken met vrij spreekuur en de 16 onderzochte praktijken met afspraakspreekuur werd de uitstelduur bepaald, waarbij rekening gehouden werd met leeftijd, geslacht en opleiding van de patiënt, en met de aard van de klacht. Het verschil tussen de gemiddelden van beide populaties werd eenzijdig getoetst met de Kendall's Tau toets met een significantiedrempel van 0,1 . Hierbij bleek dat de onderzochte patiënten in praktijken met vrij spreekuur langer uitstelden dan in praktijken met afspraakspreekuur (Zie bijlage II, tabel 4.4.3.1., uitgewerkt in figuur 12).

Ten aanzien van de onderzochte groepen jongere en oudere patiënten, en mannen en vrouwen bleek, dat patiënten in praktijken met vrij spreekuur langer uitstelden dan in praktijken met afspraakspreekuur (Zie bijlage II, tabel 4.4.3.2., 4.4.3.3., 4.4.3.4. en 4.4.3.5.). 


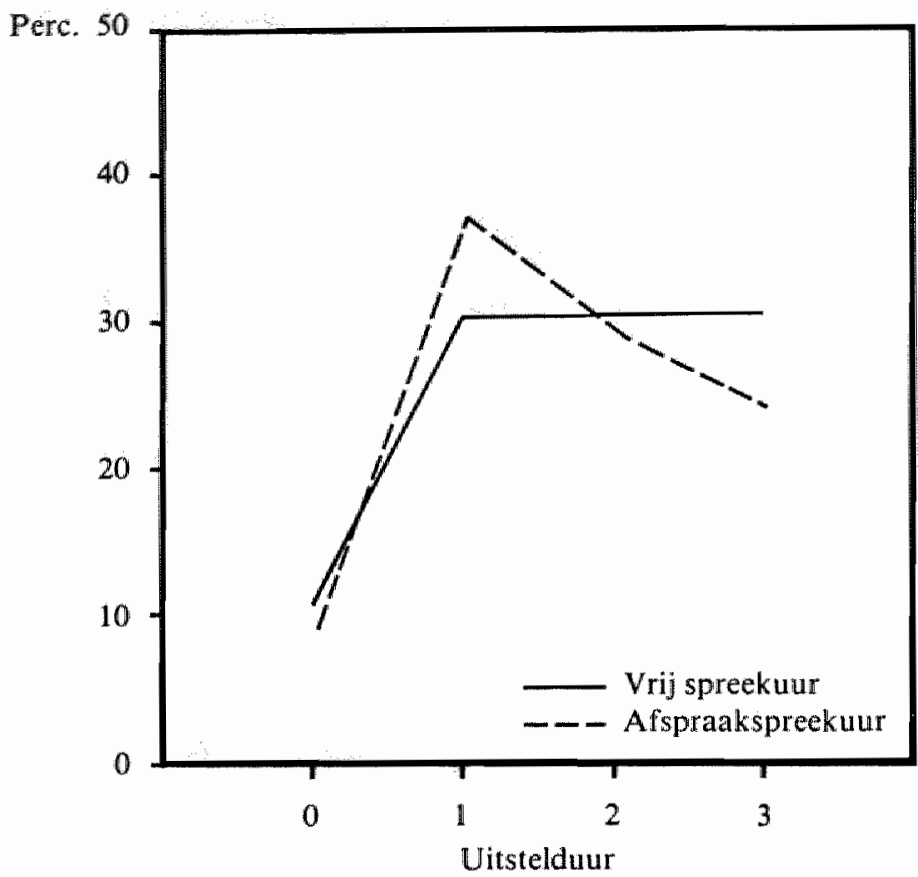

Fig. 12. Percentages patienten in praktijken met vrij resp. atspraakspreekuu in relatie tot de uitstelduur.

Wat het opleidingsniveau betreft bleek dat de onderzochte patiënten met lagere en hogere opleidingen, in praktijken met vrij spreekuur langer uitstelden dan in praktijken met afspraakspreekuur (Zie bijlage II, tabel 4.4.3.6. en 4.4.3.7.).

Ten aanzien van de aard van de klacht bleek dat bij:

- klachten van de luchtwegen, hartklachten, gezwellen en huidklachten, de onderzochte patiënten in praktijken met vrij spreekuur langer uitsteiden dan in praktijken met afspraakspreekuur (Zie bijlage II, tabel 4.4.3.8., 4.4.3.9., 4.4.3.10. en 4.4.3.11.);

- alle overige onderzochte klachtengroepen hieromtrent geen verschil aantoonbaar was.

Conclusie: In tegenstelling tot de hypothese bleek zowel ten aanzien van de totale populatie als ten aanzien van de onderzochte groepen jongeren en ouderen, mannen en vrouwen, patiënten met lagere en hogere opleidingen, dat patiënten in praktijken met vrij spreekuur langer uit- 
stelden dan in praktijken met afspraakspreekuur. Ook ten aanzien van de aard van de klacht bleek dat de onderzochte patiënten met hartklachten, klachten van de luchtwegen, gezwellen en huidklachten, in praktijken met vrij spreekuur langer uitstelden dan in praktijken met afspraakspreekuur. In geen der onderzochte groepen was de hypothese aantoonbaar.

\subsubsection{HYP. XIII. IN GROTERE PRAKTIJKEN STELLEN PATIENTEN LANGER UIT DAN IN KLEINERE PRAKTIJKEN.}

Van patiënten in praktijken met verschillende praktijkgroottes, zoals weergegeven op pagina 67 , werd de uitstelduur bepaald, waarbij rekening gehouden werd met leeftijd, geslacht en opleiding van de patiënt, en met de aard van de klacht. Het verschil tussen de gemiddelden van de onderzochte vier populaties werd eenzijdig getoetst met de Kendall's Tau toets met een significantiedrempel van 0,1 . Hierbij bleek dat noch ten aanzien van de totale populatie, noch ten aanzien van de onderzochte variabelen leeftijd, geslacht en opleiding van de patiënt, een verschil in uitstelduur aantoonbaar was.

Ten aanzien van de klacht bleek dat bij:

- algemene klachten, de onderzochte patiënten in grotere praktijken langer uitstelden dan in kleinere praktijken (Zie bijlage II, tabel 4.4.4.1.);

- k.n.o.-klachten en huidklachten, de onderzochte patiënten in kleinere praktijken langer uitstelden dan in grotere praktijken (Zie bijlage II, tabel 4.4.4.2. en 4.4.4.3.);

- de overige klachtengroepen hieromtrent geen verschil in uitstelduur aantoonbaar was.

Conclusie: Enerzijds stelden patiënten met huidklachten of k.n.o.-klach-ten in kleinere praktijken langer uit. Anderzijds stelden patiënten met algemene klachten in grotere praktijken langer uit. De hypothese was niet aantoonbaar.

4.4.5. HYP. XIV. BIJ OUDERE HUISARTSEN ( $\geqslant 40$ IR.) STELLEN PATIENTEN LANGER UTT DAN BIJ JONGERE HUISARTSEN $(<40$ JR.).

Van de patiënten die hun jongere $(<40$ jr. $)$ en oudere $(\geqslant 40$ jr. $)$ huisartsen consulteerden werd de uitstelduur bepaald, waarbij rekening ge- 
houden werd met leefujd, geslacht en opleiding van de patiënt, en met de aard van de klacht. Het verschil tussen de gemiddelden van beide populaties werd eenzijdig getoetst met de Kendall's Tau toets met een significantiedrempel van 0,1 . Hierbij bleek dat de onderzochte patiënten bij oudere huisartsen langer uitstelden dan bij jongere huisartsen (Zie bijlage $\mathrm{II}$, tabel 4.4.5.1., uitgewerkt in figuur 13).

Ten aanzien van de leeftijd bleek dat oudere patiënten in de populatie bij oudere huisartsen langer uitstelden dan bij jongere huisartsen (Zie bijlage II, tabel 4.4.5.2.).

Bij vrouwen bleek dat de onderzochte vrouwen bij oudere huisartsen langer uitstelden dan bij jongere huisartsen (Zie bijlage II, tabel 4.4.5.3.). Wat het opleidingsniveau betreft bleek dat patiënten in de populatie met lagere opleidingen, bij oudere huisartsen langer uitstelden dan bij jongere huisartsen (Zie bijlage II, tabel 4.4.5.4.).

Ten aanzien van de aard van de klacht bleek dat bij:

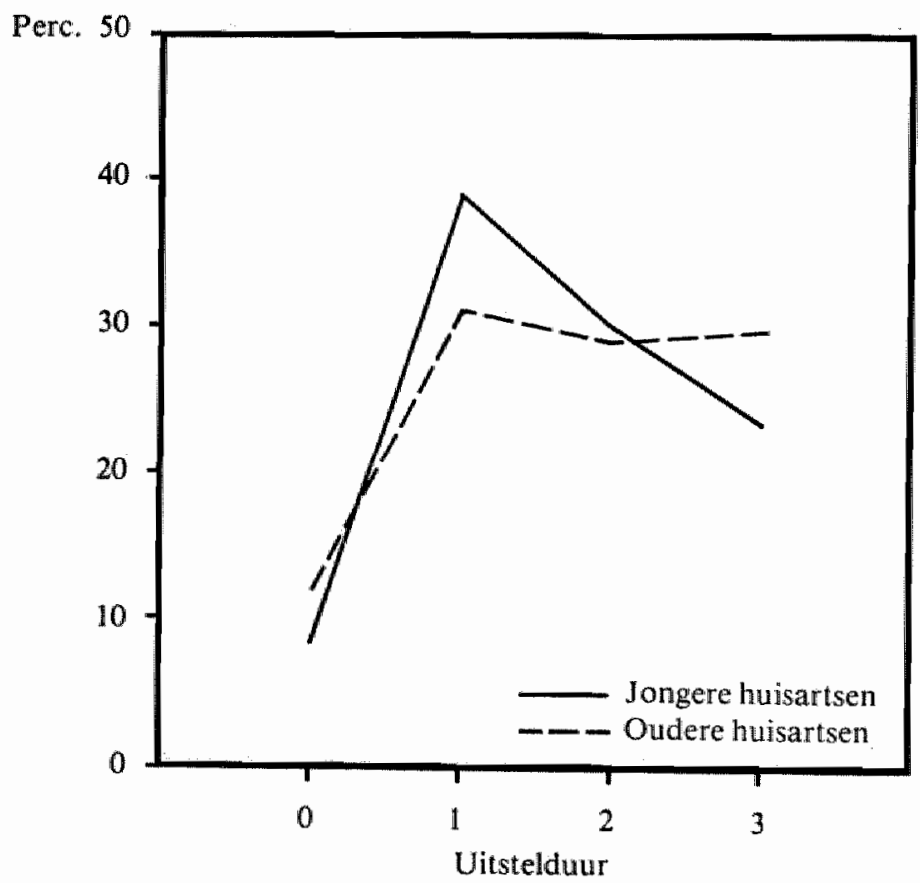

Fig. 13. Percentages patienten bij jongere resp. oudere haisartsen in relatie tot de uistelduur. 
- klachten van de luchtwegen en huidklachten, de onderzochte patiènten bij oudere huisartsen langer uitstelden dan bij jongere huisartsen (Zie bijlage II, tabel 4.4.5.5. en 4.4.5.6.);

- de overige klachtengroepen hieromtrent geen verschil in uitstelduur aantoonbaar was.

Conclusie: Zowel ten aanzien van de totale populatie als ten aanzien van de onderzochte groepen ouderen, vrouwen en patiënten met lagere opleidingen, waren de gevonden gegevens in overeenstemming met de hypothese. Ten aanzien van de aard van de klacht was de hypothese bij huidklachten eveneens aantoonbaar.

\subsection{SAMENVATTING}

Uit het onderzoek bleek ten aanzien van de eigenschappen van de patiënt:

- vrouwen stelden langer uit dan mannen;

- oudere patiënten $(\geqslant 46$ jr.) stelden langer uit dan jongere patiënten $(17-45$ jr. $)$;

- patiënten met hogere opleidingen stelden langer uit dan patiënten met lagere opleidingen;

- tussen consultfrequenties en uitstelduur kon in het merendeel der onderzochte groepen geen verband worden vastgesteld;

- in plattelandspraktijken stelden patiënten langer uit dan in stadspraktijken;

- patiënten die meer ervaring hadden met de klacht, in die zin dat zij de klacht al eens eerder hadden gehad eventueel daarvoor waren behandeld, stelden bij minder en minst ernstige klachten langer uit dan patiënten die geen ervaring hadden met de klacht.

Ten aanzien van eigenschappen van de klacht bleek:

- bij klachten die algemeen bekend staan als mogelijke aanwijzingen voor een ernstige ziekte, stelden patiënten korter uit dan bij klachten die niet algemeen bekend staan als mogelijke aanwijzingen voor een ernstige ziekte;

- bij klachtenpatronen gepaard gaande mèt pijn stelden patiënten korter uit dan bij klachtenpatronen zònder pijn.

- bij klachten die als overwegend psychisch werden aangemerkt, stelden patiënten langer uit dan bij klachten die als overwegend somatisch werden aangemerkt. 
Ten aanzien van eigenschappen van de huisarts en zijn praktijk bleek:

- wanneer huisartsen relatief meer klachten als psychisch aangaven, was de uitstelduur van patiënten in liun praktijken langer dan wanneer zij relatief meer klachten als somatisch aanmerkten;

- tussen patiënten in associatie- en solopraktijken was geen verschil in uitsteldurur aantoonbaar;

- in praktijken met vrij spreekuur stelden patiënten langer uit dan in praktijken met afspraakspreekuur;

- tussen patienten in grotere en kleinere praktijken was geen verschil in uitstelduur aantoonbaar;

- bij oudere huisartsen $(\geqslant 40 \mathrm{jr}$.) stelden patiënten langer uit dan bij jongere huisartsen $(<40 \mathrm{jr}$. $)$. 


\section{Nadere analyses}

\subsection{INLEIDING}

In het voorgaande hoofdstuk vond de toetsing van de afzonderlijke hypothesen plaats. In detail werd ingegaan op de veertig klachten van de patiënt. In dit hoofdstuk willen we tot synthese komen. Voor de nietmethodologisch geïnteresseerde lezer wordt opgemerkt dat aan het begin van het volgende hoofdstuk een korte samenvatting wordt gegeven.

Indien een aantal hypothesen afzonderlijk en in detail worden getoetst, blijven een aantal belangrijke vragen onbeantwoord. Tussen de verschillende onafhankelijke variabelen, die in de hypothesen zijn vermeld als mogelijke determinanten van de uitstelduur, kunnen allerlei interacties en verbanden bestaan, die ertoe leiden dat sommige hypothesen ten onrechte worden bevestigd, en misschien andere ten onrechte niet aantoonbaar zijn. Een definitieve uitspraak over de houdbaarheid van een hypothese is dan ook alleen te doen als bij de toetsing, de invloed van alle andere in de overige hypothesen vermelde variabelen wordt uitgeschakeld. Technisch gezegd betekent dit dat een samenhang tussen de uitstelduur en de verklarende variabele pas kan worden aanvaard, als de overige verklarende variabelen constant worden gehouden.

Naast de noodzaak een in de samenvattende analyse eventueel doorkruisende factor constant te houden, doet zich nog een tweede probleem voor. Het is denkbaar dat een hypothese niet houdbaar is voor de onderzochte populatie als geheel, maar slechts voor een gedeelte daarvan. Een voorbeeld daarvan zou zijn, als een verschil in uitstelduur tussen praktijken met afspraak- en vrij spreekuur, wel aantoonbaar is bij een geringe ernst van de klacht, maar niet bij een grote ernst van de klacht. Om deze vragen rond de samenhang van de hypothesen en de op grond daarvan ontwikkelde variabelen te beantwoorden is gebruik van multivariate analyse noodzakelijk. Gekozen is voor twee technieken.

- Multipele regressieanalyse schat de bijdrage van elke onafhankelijke variabele (leeftijd, geslacht enz.) in de verklaarde variantie van de afhankelijke variabele (uitstelduur), nadat voor alle andere variabelen 
gecontroleerd is. Met behulp van deze techniek wordt elke variabele behandeld, alsof ze in een afzonderlijke stap aan de regressievergelijking wordt toegevoegd, nadat alle andere variabelen hun deel van de variantie in de afhankelijke variabele verklaard hebben. Deze methode stelt enerzijds hoge eisen aan het materiaal, maar geeft anderzijds onweerlegbaar antwoord op de vraag òf interacties plaatsvinden.

- Contrastgroepenanalyse onderzoekt de gelijktijdige werking van een aantal onafhankelijke variabelen op een afhankelijke variabele. De contrastgroepenanalyse bestaat uit afzonderlijke stappen, waarbij bij iedere stap gezocht wordt naar diế dichotomie, welke het beste contrast geeft in de variantie van de afhankelijke variabele. De contrastgroepenanalyse stelt minder hoge eisen aan het materiaal dan de multipele regressieanalyse en geeft meer details. De patiënten worden op basis van één van de onafhankelijke variabelen (de variabele die de grootste samenhang vertoont met de uitstelduur van de patiënt) zo ingedeeld in twee groepen, dat het verschil ten aanzien van de uitstelduur maximaal. is. Vervolgens worden deze twee groepen op dezelfde wijze gesplitst en wel op basis van de variabele die nú de grootste samenhang met de uitstelduur vertoont. Op deze wijze worden afle groepen steeds gesplitst totdat de verklaarde variantie te klein wordt of het aantal patiënten te gering. Op deze wijze ontstaat een ,,boomstructuur" (figuur).

Speciaal geïnteresseerd zijn we in de variabelen betreffende kenmerken van de huisarts en zijn praktijk. In de overige onafhankelijke variabelen wordt, door middel van samenvoeging van sommige variabelen, getracht een reductie aan te brengen. Ten aanzien van de variabelen betreffende kenmerken van de patiënt blijkt geen samenvoeging mogelijk te zijn. Ten aanzien van de variabelen betreffende kenmerken van de klacht is deze mogelijkheid wel aanwezig, waarbij de variabelen klachtenpatronen mèt of zònder pijn, ernst van de klacht en overwegend somatisch of psychisch karakter van de klacht, worden samen genomen tot éen nieuwe variabele. Door deze samenvoeging kan de verdere statistische bewerking alleen plaatsvinden ten aanzien van patiënten, waarbij deze drie variabelen betreffende kenmerken van de klacht allen bekend zijn. Tevens dient er voor sommige multivariate analyse alle patiënten met ontbrekende scores op welke variabele dan ook te worden weggelaten. De onderzoekpopulatie wordt daardoor teruggebracht van 2070 patiënten naar een laagste waarde van 1689 patiënten. Alvorens de resultaten te tonen enkele woorden over de nieuwe variabele: de urgentiegraad van de klacht. 
In het vorige hoofdstuk bleek dat de drie afzonderlijke kenmerken van de klacht, namelijk of de klacht al of niet op een ernstige aandoening duidt, of de klacht al dan niet gepaard gaat met pijn en of de klacht overwegend somatisch of psychisch van aard is, samenhang vertonen met de uitstelduur van de patiënt. Onderling vertonen deze variabelen ook een zekere samenhang. Klachten die op een ernstige aandoening duiden resp. klachtenpatronen mèt pijn resp. overwegend somatische klachten, worden door de patiënt doorgaans als meer urgent ervaren dan klachten die niêt op een ernstige aandoening duiden resp. klachtenpatronen zònder pijn resp. overwegend psychische klachten.

Bij nadere beschouwing van de drie kenmerken van de klacht blijkt dat deze alle drie een zekere consistentie aangeven ( $C$ volgens HoYt is 0,59 ). Deze consistentiemaat is voldoende hoog om deze drie variabelen samen te nemen. Daardoor zijn we in staat de drie kenmerken van de klacht te reduceren tot één. Dit betekent wel dat een bepaald gedeelte van de verklaarde variantie, die voor ons onderzoek minder interessant is, wordt uitgesloten.

Samenvattend wordt de urgentiegraad van de klacht bepaald door:

a. De mate waarin de klachten als ernstig worden ervaren:

- 11 Meest ernstige klachten

- 18 Minder ernstige klachten

- 11 Minst ernstige klachten

b. De al of niet aanwezigheid van pijn bij de klachten:

- Klachten mèt pijn

- Klachten zònder pijn

c. Het karakter van de klacht wat betreft:

- Overwegend somatische klacht

- Overwegend psychische klacht

Door samenvoeging van deze kenmerken van de klacht ontstaat een schaal die verloopt van 7 tot 3 , met vijf verschillende graden van urgentie, waarbij $7(=3+2+2)$ de hoogste urgentiegraad voorstelt en 3 $(=1+1+1)$ de laagste urgentiegraad. 
Tabel 5.2.1. Frequentietabel urgentiegraad wan de klacht.

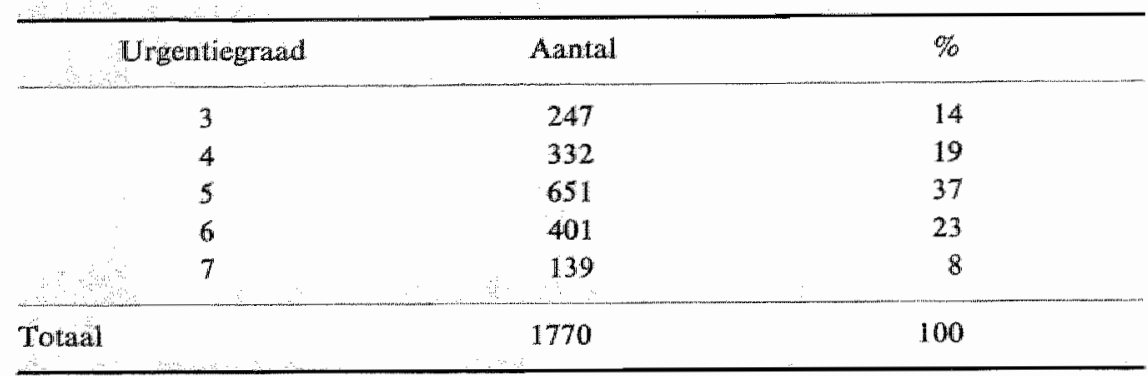

Missing cases: 300

\subsection{MULTIPELE REGRESSIEANALYSE}

In de voorgaande paragraaf werden de kenmerken van de klacht samengevoegd tot een nieuwe variabele:

- de urgentiegraad.

Daarnaast zijn onderstaande verklarende variabelen voor de analyse behouden:

$$
\begin{aligned}
\text { Patiënt: } & \text { - geslacht: } \\
& \text { - leeftijd; } \\
& \text { - opleiding; } \\
& \text { - frequentie patiënt-arts contacten; } \\
& \text { - stads-/plattelandspatiënt; } \\
& \text { - ervaring met de klacht. }
\end{aligned}
$$

Huisarts en praktijk: - artsen met relatief meer somatische resp. psychische klachten in hun praktijk;

- samenwerkingsverband;

- spreekuurvorm;

- praktijkgrootte;

- leeftijd huisarts.

Al deze onafhankelij ke variabelen zijn in de regressieanalyse opgenomen, waarbij de uitstelduur de afhankelijke variabele is.

De regressieanalyse stelt in principe hoge eisen aan het materiaal:

a. De variabelen zouden continuïteit moeten bezitten.

b. De variabelen zouden normaal verdeeld moeten zijn.

c. De techniek is erg gevoelig voor in het materiaal voorkomende hoge correllaties tussen de onafhankelijke variabelen. 
Ten aanzien van $a$ en $b$ geldt dat het materiaal hier in lang niet alle opzicht aan voldoet. Het is echter gebruikelijk met voorzichtigheid toch deze analysetechniek aan te wenden, daar hij niet bijzonder gevoelig is voor afwijkingen. In ieder geval leiden de tekorten bijna altijd tot onderschatting van eventuele verbanden, niet tot overschatting.

Ten aanzien van $\mathrm{c}$ geldt dat tussen de variabelen nauwelijks hoge correlaties aanwezig zijn ( $\mathrm{Zie}$ bijlage $\mathrm{Ir}$, tabel 5.3.1.), behoudens dat een cluster van sterk samenhangende variabelen bestaat uit stad/platteland, spreekuurvorm, patiëntenaantal en som./psych. arts (Zie tabel 5.3.2.).

Tabel 5.3.2. Variabellen met een relatief hoge correlatie-coëfficiënt.

\begin{tabular}{lccc}
\hline & Spreekuurvorm & Patiëntenaantal & Som./psych. arts \\
\hline Stad/platteland & 0,63 & 0,25 & $-0,48$ \\
& Spreekuurvorm & 0,40 & $-0,31$ \\
& & Patiëntenaantal & $-0,19$ \\
\hline
\end{tabular}

Uit ons onderzoekmateriaal blijkt dat in plattelandspraktijken relatief meer vrije spreekuren voorkomen, de praktijken overwegend groter zijn en de huisartsen relatief meer klachten als somatisch duiden. Dit komt overeen met de globale indruk over plattelandspraktijken, zoals die in ons land bestaan. Bij de beoordeling van het materiaal dient men rekening te houden met de aanwezigheid van deze hoge correlaties. Bij het constant houden van de variabelen kan namelijk de situatie ontstaan, dat die correlatie, tussen een van deze vier variabelen en de uitstelduur, die toevallig het hoogst uitvalt, veel gemakkelijker behouden blijft dan andere, terwijl zelfs het niet uitgesloten is dat de verlaging van de andere drie correlaties tot tekenverandering leidt bij partialisering van hoge orde.

De multipele regressieanalyse op de uitstelduur staat weergegeven in tabel 5.3.3. Belangrijkste maat daarin is de gestandaardiseerde partiële regressiecoëfficiënt, ook bèta genoemd. Deze geeft aan het aantal standaarddeviatie-eenheden veranderingen in $f(x)=Y$, als de onafhankelijke variabele $x$ zou toenemen met 1 standaarddeviatie-eenheid, onder constant houden van alle overige. Zo zou de voorspelde score in $\mathrm{x}$ met .24 standaarddeviatie-eenheid afnemen als de urgentiegraad met 1 standaarddeviatie-eenheid zou toenemen en de overige variabelen gelijk zouden blijven. De grootte en het teken van de regressiecoëfficiënt geven het relatieve belang en de richting van de invloed aan. 
Tabel 5.3.3. Stapsgewijze regressizanalyse.

\begin{tabular}{|c|c|c|c|}
\hline \multirow[b]{2}{*}{ Onafhankelijk } & \multicolumn{2}{|c|}{ Aflankelik: De uitstelduar } & \multirow[b]{2}{*}{ Correlatie O-orde } \\
\hline & Bèta & $\mathbf{F}$ & \\
\hline Urgentiegraad klacht & -.24 & 102.78 & -.25 \\
\hline Geslacht patiènt & -.13 & 30.91 & -.14 \\
\hline Spreekuurvorm & -.13 & 17.05 & -.08 \\
\hline Stad/platteland & .10 & 8.99 & -.03 \\
\hline Leeftijd patiênt & .09 & 15.47 & .08 \\
\hline Pat.arts contacten & -.07 & 7.90 & -.00 \\
\hline Leeftijd huisarts & .07 & 7.21 & .05 \\
\hline Som./psych. arts & .06 & 4.71 & .09 \\
\hline Opleiding patiênt & .05 & 4.94 & .04 \\
\hline Ervaring met klacht & .05 & 4.35 & .08 \\
\hline
\end{tabular}

We zien dat de verklaarde variantie $\left(\mathrm{R}^{2}\right)$ in uitstelduur ten gevolge van deze onderzochte onafhankelijke variabelen slechts $11 \%$ bedraagt. Dit is niet hoog te noemen. Het grootste deel van de variantie in de afhankelijke variabele kan dus niet verklaard worden door deze set van variabelen. Allerlei unieke aspecten van de patiënt, zijn klacht en zijn huisarts spelen kennelijk een grotere rol. Toch blijkt uit tabel 5.3.3. dat de meeste variabelen bij deze analyse significante uitkomsten geven. Dit heeft echter niet veel betekenis gezien de lage waarden van de bèta's, waarbij slechts drie waarden eruit springen.

Onweerlegbaar vertonen samenhang met de uitstelduur:

- de urgentiegraad van de klacht, waarbij patiënten bij klachten met een hoge urgentiegraad gemiddeld korter uitstelden dan bij klachten met een lage urgentiegraad;

- het geslacht van de patiënt, waarbij mannen gemiddeld korter uitstelden dan vrouwen;

- de spreekuurvorm, waarbij patiënten in praktijken met afspraakspreekuur gemiddeld korter uitstelden dan in praktijken met vrij spreekuur.

Twee variabelen, namelijk patiëntenaantal en samenwerkingsverband, vertonen géén samenhang met de uitstelduur van de patiënt. De overige zeven variabelen geven een zo geringe samenhang te zien, dat het aanbeveling verdient de verdere analyse af te wachten. 
Uit het bovenstaande blijkt dat de urgentiegraad veruit het grootste effect heeft op de uitstelduur. Daarom bestuderen we nu de samenhang tussen de onafhankelijke variabelen en de afhankelijke variabele voor iedere urgentiegraad afzonderlijk.

In de tabellen 5.3.4., 5.3.5., 5.3.6., 5.3.7. en 5.3.8. (Zie bijlage II) worden de gestandaardiseerde partiële regressiecoëfficiënten voor iedere urgentiegraad afzonderlijk weergegeven. Uit deze tabellen zijn in tabel 5.3.9. ter illustratie alléén de significante bèta's bij elkaar gezet.

Tabel 5.3.9. Gestandaardiseerde regressiecoëfficiënten.

\begin{tabular}{|c|c|c|c|c|c|}
\hline \multirow[b]{2}{*}{ Onafhankelijk } & \multicolumn{5}{|c|}{ Afhankelijk: Uitstelduur per urgentiegraad } \\
\hline & 3 & 4 & 5 & 6 & 7 \\
\hline Geslacht patiënt & $-.18^{* * *}$ & $-.12 *$ & 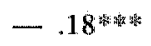 & & \\
\hline Leeftijd patient & & & .12 管的为 & & 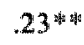 \\
\hline Spreekuurvorm & & 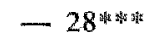 & 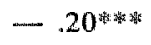 & & \\
\hline Leeftijd huisarts & & 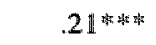 & $.11 *$ & & \\
\hline Stad/platteland & & $.32^{* * 2 * x^{*}}$ & & & \\
\hline Som. psych. arts & $-.17^{\text {菂 }}$ & .19 *出半 & & $.133^{*}$ & \\
\hline Pat.-arts contacten & & & $-.08^{*}$ & & \\
\hline Opleiding patiënt & & $.12 *$ & & & \\
\hline Ervaring met klacht & & $.11 *$ & & & \\
\hline \multirow[t]{2}{*}{ Multipele $\mathrm{R}$} & .28 * & .39 先水珠 & 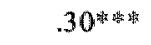 & .20 & .31 \\
\hline & & & & n.s. & n.s. \\
\hline
\end{tabular}

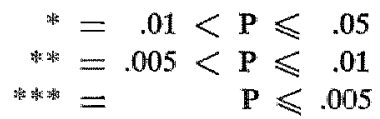

Allereerst blijkt dat bij de hoogste urgentiegraden geen significante multipele correlaties optreden. Dit betekent dat bij de hoogste urgentiegraden van de klacht, op de uitstelduur nauwelijks andere variabelen uit ons onderzoek een rol spelen dan de klacht zelf. Bij lage en gemiddelde urgentiegraden van de klacht blijkt de multipele regressieanalyse tot meer significante uitkomsten te leiden, waarbij de meest duidelijke effecten gevonden worden bij klachten met urgentiegraad 4 en 5 . Opvallend is het geringe aantal significante uitkomsten bij urgentiegraad 3. Een mogelijke verklaring hiervoor kan zijn dat in deze groep consulten aanwezig zijn, die niet direct een klacht zijn (b.v. eerste pilconsult, te dik). Deze consulten bezitten een zeer lage urgentiegraad. 
Ten aanzien van de overige onafhankelijke variabelen blijkt dat:

- het geslacht van de patiënt voornamelijk bij lagere urgentiegraden samenhang vertoont met de uitstelduur, in die zin dat mannen gemiddeld korter uitstelden dan vrouwen.

- de leeftijd van de patiẻnt de enige variabele is die bij een hogere urgentiegraad van de klacht tot een significant resultaat leidt. Jongere patiënten van 17-45 jaar stelden gemiddeld korter uit dan oudere patiënten $\geqslant 46$ jaar. Mogelijk spelen hier sportletsels en ongevallen een rol.

- de spreekuurvorm tot significante resultaten leidt bij klachten met lage en gemiddelde urgentiegraden. In praktijken met afspraakspreekuur was de uitstelduur van patiënten gemiddeld korter dan in praktijken met vrij spreekuur.

- de leeftijd van de huisarts bij lage en gemiddelde urgentiegraden van de klacht samenhang vertoont met de uitstelduur. De uitstelduur van patiênten was bij huisartsen $<40$ jæar gemiddeld korter dan bij huisartsen $\geqslant 40$ jaar.

- de variabele som./psych. arts tot significante resultaten leidt bij klachten met urgentiegraad 3, 4 en 6 . Opmerkelijk is het omkeren van het teken van de regressiecoëfficiënt bij urgentiegraad 3. Dit betekent dat patiënten bij artsen, die in hun praktijk relatief meer klachten als somatisch resp. psychisch beschouwen, bij klachten met urgentiegraad 4 en 6 relatief korter resp. langer uitstelden, en bij klachten met urgentiegraad 3 relatief langer resp. korter uitstelden.

- de vier variabelen stad/platteland, patiënt-arts contacten, opleiding patiënt en ervaring met de klacht slechts bij één urgentiegraad van de klacht tot resultaat leiden, en dan nog steeds bij de midden urgentiegraden.

- de variabelen patiëntenaantal en samenwerkingsverband, zoals reeds vermeld, niet tot significante uitkomsten leiden.

\subsection{CONTRASTGROEPENANALYSE}

De regressieanalyse geeft een op zichzelf wel duidelijk beeld.

- De grootste samenhang met de uitstelduur heeft in dit onderzoek de urgentiegraad van de klacht. Een hoge urgentiegraad hangt samen met een korte uitstelduur.

- Samenhang van enige betekenis met de uitstelduur hebben het geslacht van de patiënt en de spreekuurvorm. Beiden vertonen deze samenhang met de uitstelduur bij klachten met een lage urgentiegraad 
duidelijk meer dan bij klachten met een hoge urgentiegraad, waarbij mannelijk geslacht resp. afspraakspreekuur samengaan met een korte uitstelduur.

- Samenhang van geringere betekenis met de uitstelduur hebben de variabelen leeftijd patiënt en leeftijd huisarts. Patiënten van $17-45$ jaar bij klachten met een hoge urgentiegraad, en patiënten bij huisartsen $<40$ jaar bij klachten met een lage urgentiegraad, vertonen samenhang met een korte uitstelduur.

- Tenslotte laten een aantal andere variabelen samenhang zien van zowel beperkte schaal als zeer geringe betekenis.

Om de variantie in de afhankelijke variabele te verklaren werd niet alleen gebruik gemaakt van de multipele regressievergelijkingen, maar ook van contrastgroepenanalyse (voor een uitwoerige beschrijving zie bijlage III, en de inleiding van dit hoofdstuk). De contrastgroepenmethode geeft bij elke stap aan, welke dichotomie of welke onafhankelijke variabele de meeste variantie verklaart in de afhankelijke variabele. Het voordeel van deze methode is dat alle mogelijke vooronderstellingen die bij multipele regressieanalyse gemaakt worden, hier niet van kracht zijn. Hoge correlaties zijn hierbij niet van belang. Een bezwaar van deze methode is dat geen significanties berekend kunnen worden en alleen gesplitst kan worden op het hoogste percentage verklaarde variantie. Deze methode werkt meer hiërarchisch.

De grens van de verklaarde variantie wordt in dit onderzoek bij iedere splitsing bepaald op $20 \%$. Bij de keuze voor dit criterium komt het percentage verklaarde variantie $(11,5 \%)$ het dichtst in de buurt te liggen van het bij de regressieanalyse gevonden percentage $(10,9 \%)$.

De eerste splitsingen (figuur 14) werden teweeggebracht door de urgentiegraad van de klacht. Deze variabele bleek ook bij deze methode de grootste samenhang te hebben met de uitstelduur van de patiënt. Daarna volgden geslacht en leeftijd van de patiënt, gevolgd door spreekuurvorm en leeftijd huisarts.

In tabel 5.4.1. wordt een overzicht gegeven van de verklaarde variantie in de contrastgroepenanalyse. Tevens wordt aangegeven welke variabelen wel en welke niet een bijdrage hebben geleverd aan het verklaren van de uitstelduur van de patiënt. 


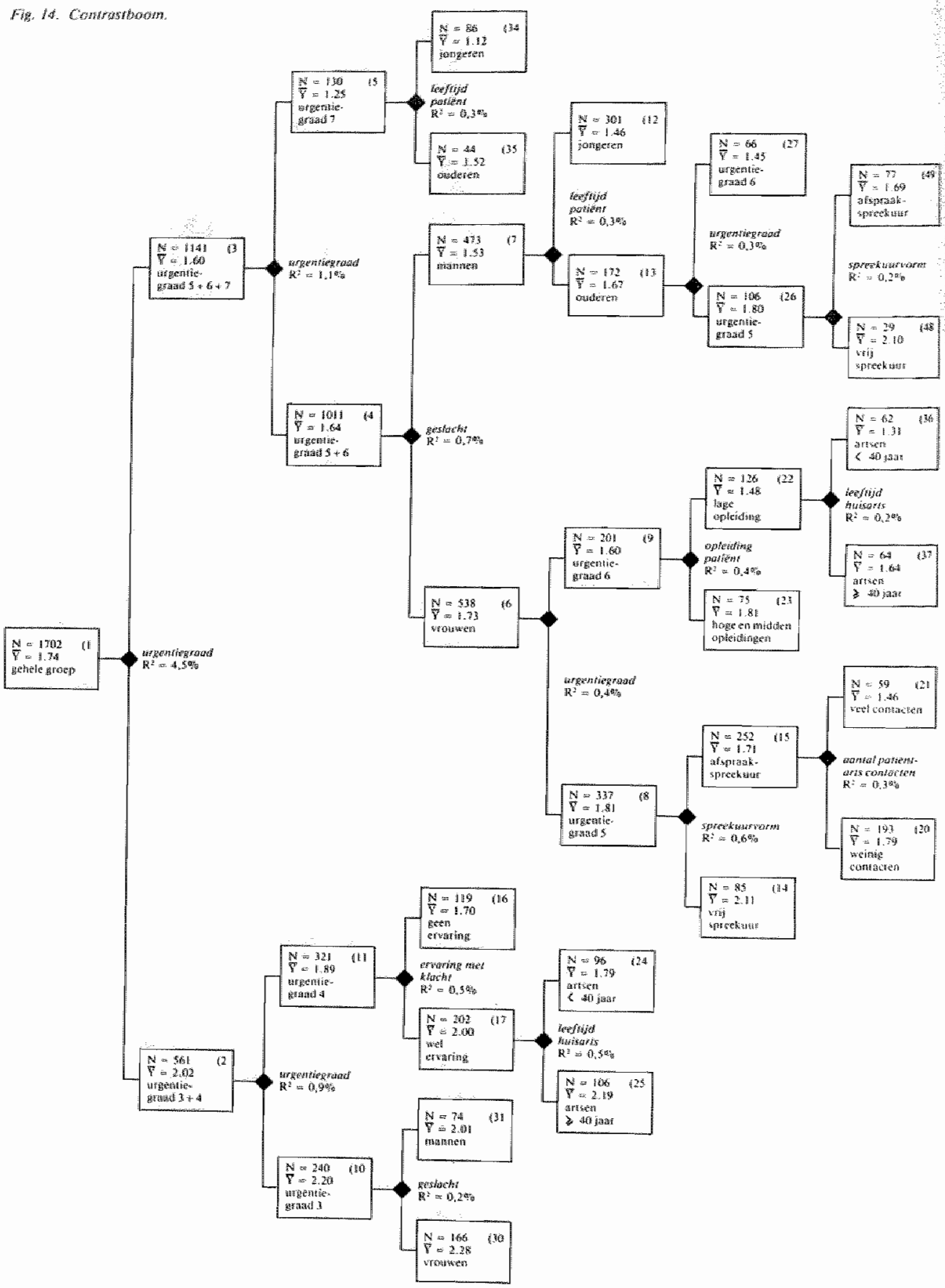


Tabel 5.4.1. Verklaarde variantie in contrastgroepenanalyse van de uitsteldumr van de patient.

\begin{tabular}{lc}
\hline Onafhankelije variabelen & $\begin{array}{c}\text { Percentage } \\
\text { verklaarde variantie }\end{array}$ \\
\hline Urgentiegraid klacht & 7,1 \\
Geslacht patiënt & 0,9 \\
Spreekuurvorm & 0,9 \\
Stad/platteland &,-- \\
Leeftijd patiënt & 0,6 \\
Pat.-arts contacten & 0,3 \\
Leeftijd huisarts & 0,8 \\
Som./psych. arts &,- \\
Opleiding patiënt & 0,4 \\
Ervaring met klacht & 0,5 \\
Patiëntenaantal &,-- \\
Samenwerkingsverband &,-- \\
\hline Totaal verklaarde variantie & 11,5 \\
\hline
\end{tabular}

Totaal verklarende wariantie $11,5 \%$.

Per groep wordt vermeld:

$N=$ aantal patiènten per subgroep;

$\bar{Y}=$ gemiddelde warde wan de afhankelijke variabele (de uitsfelduur) per subgroep;

- : Hierbij wordt aangegever op welke onathankelijke warabelen ae splitsing plaatsvind:;

$R^{2}=$ de verklaarde variantie behorende bij de desberreffende splitsing.

Criteria voor de splitsing:

- variantie reductie per stap $2 \%$;

- minimale groepsgrootre 25 ;

- maximum aantal groepen 50.

De totale groep warmee gestart werd betrof 1702 patienten. Dit komt doordat de ontbrekende warden op een van de variabelen als consequentie heeft dat de desbetreffende patiënt niet in de analyse wordi opgenomen. 
Uit tabel 5.4.1. blijkt dat dezelfde drie variabelen als bij de multipele regressieanalyse van belang zijn: urgentiegraad van de klacht, geslacht van đe patiënt en spreekuurvorm.

Van minder belang zijn de variabelen leeftijd huisarts en leeftijd patiënt voor de variantie in uitstelduur.

De variabelen ervaring met klacht, opleiding patiënt en patiënt-arts contacten zijn slechts van geringe betekenis voor de variantie in uitstelduur. De variabelen stad/platteland, som./psych. arts, patiëntenaantal en samenwerkingsverband zijn niet van belang voor de uitstelduur van de patiẽnt. Op grond hiervan kan worden gesteld dat de relaties met urbanisatie en som./psych. arts bij de regressieanalyse waarschijnlijk het gevolg zijn van de problematiek van de hoge correlaties.

Bij nadere beschouwing van figuur 14 zien we dat in het bovenste gedeelte van de figur de hogere urgentiegraden resp. een kortere gemiddelde uitsteldurur (Y) staan weergegeven, en in het onderste gedeelte de lagere urgentiegraden resp. een langere gemiddelde uitstelduur.

Uit de boomstructuur kunnen wij de volgende ,eindgroepen" aflezen: Eindgroep 34; jongere patiënten (17-45 jr.) die hun huisarts consulteren wegens klachten met een hoogste urgentiegraad (7).

Eindgroep 35 ; oudere patiënten ( $\geqslant 46 \mathrm{jr}$ ) die hun huisarts consulteren wegens klachten met een hoogste urgentiegraad (7).

Eindgroep 12; jongere mannen die hun huisarts consulteren wegens klachten met een gemiddelde tot hoge urgentiegraad (5 en 6).

Eindgroep 27; oudere mannen die hun huisarts consulteren wegens klachten met een hoge urgentiegraad (6).

Eindgroep 49; oudere mannen die hun huisarts consulteren in praktijken met afspraakspreekuur wegens klachten met een gemiddelde urgentiegraad (5).

Eindgroep 48; oudere mannen die hun huisarts consulteren in praktijken met vrij spreekuur wegens klachten met een gemiddelde urgentiegraad (5). Eindgroep 36; vrouwen met een lage opleiding die hun jongere huisarts $(<40 \mathrm{jr}$.) consulteren wegens klachten met een hoge urgentiegraad (6). Eindgroep 37; vrouwen met een lage opleiding die hun oudere huisarts $(\geqslant 40$ jr.) consulteren wegens klachten met een hoge urgentiegraad (6). Eindgroep 23; vrouwen met midden en hoge opleidingen die hun huisarts consulteren wegens klachten met een hoge urgentiegraad (6).

Eindgroep 21; vrouwen met frequente patiënt-arts contacten die hun huisarts consulteren in praktijken met afspraakspreekuur wegens klachten met een gemiddelde urgentiegraad (5). 
Eindgroep 20; vrouwen met weinig patiënt-arts contacten die hun huisarts consulteren in praktijken met vrij spreekuur wegens klachten met een gemiddelde urgentiegraad (5).

Eindgroep 14; vrouwen die hun huisarts consulteren in praktijken met vrij spreekuur wegens klachten met een gemiddelde urgentiegraad (5). Eindgroep 16; patiënten die géén ervaring hebben met de klacht en hun huisarts consulteren wegens klachten met een lage urgentiegraad (4). Eindgroep 24; patiënten die ervaring hebben met de klacht en hun jongere huisarts $(<40$ jr.) consulteren wegens een klacht met een lage urgentiegraad (4).

Eindgroep 25; patiënten die ervaring hebben met de klacht en hun oudere huisarts $(\geqslant 40 \mathrm{jr}$ ) consulteren wegens een klacht met een lage urgentiegraad (4).

Eindgroep 31; mannen die hun huisarts consulteren wegens klachten met een laagste urgentiegraad (3).

Eindgroep 30; vrouwen die hun huisarts consulteren wegens klachten met een laagste urgentiegraad (3).

\subsection{CONCLUSIE}

De resultaten van de multipele regressieanalyse en de contrastgroepenanalyse blijken in grote lijnen met elkaar in overeenstemming te zijn. Bij vergelijking van tabel 5.3.9. en figuur 14 (de contrastboom) blijkt dat onderstaande variabelen, uitgesplitst per urgentiegraad van de klacht, bij beide analysemethoden samenhang vertonen met de uitstelduur van de patiënt (Zie tabel 5.5.1.).

Tabel 5.5.1. Variabelen, die uitgesplitst per urgentiegraad, zowal bij de multipele regressieanalyse als de contrastgroepenanalyse samenhang vertonen met de uitstelduur van de patiërnt.

\begin{tabular}{|c|c|c|c|c|c|}
\hline \multirow[b]{2}{*}{ Onathankelijk } & \multicolumn{5}{|c|}{ Afhankelijk: Uitstelduur per urgentiegraad } \\
\hline & 3 & 4 & 5 & 6 & 7 \\
\hline Geslacht patient & $\mathrm{x}$ & & $\mathrm{x}$ & & \\
\hline Leeftijd patiënt & & & $\mathrm{x}$ & & $\mathrm{x}$ \\
\hline Spreekuurvorm & & $\mathrm{x}$ & $\mathrm{x}$ & & \\
\hline Leeftijd huisarts & & $\mathrm{x}$ & & & \\
\hline Pat_-arts contacten & & & $\mathrm{x}$ & & \\
\hline Ervaring met klacht & & $\mathrm{x}$ & & & \\
\hline
\end{tabular}


In tabel 5.5.1. zien we dat de drie variabelen: geslacht patiënt, leeftijd patiënt en spreekuurvorm, zowel bij de multipele regressieanalyse als de contrastgroepenanalyse, bij twéé overeenkomstige urgentiegraden van de klacht samenhang vertonen met de uitstelduur van de patiënt.

De variabelen leeftijd huisarts, patiënt-arts contacten en ervaring met de klacht vertonen deze samenhang bij beide analyses slechts bij één overeenkomstige urgentiegraad van de klacht. We merken op dat bij de variabele leeftijd huisarts, bij de contrastgroepenanalyse een factor van enig gewicht behouden blijft.

Gegeven de uitkomsten van de multipele regressieanalyse en de contrastgroepenanalyse kunnen we stellen dat:

- de urgentiegraad van de klacht een duidelijk verband heeft met de uitstelduur van de patiënt. Een hoge resp. lage urgentiegraad vertoont samenhang met een korte resp. lange uitstelduur.

- de structurele variabelen geslacht en leeftijd van de patiènt eveneens samenhang vertonen met de uitstelduur van de patiënt, waarbij een oudere leeftijd resp. vrouwelijk geslacht samenhang vertoont met een langere uitstelduur, en een jongere leeftijd resp. mannelijk geslacht met een kortere uitstelduur.

- ten aanzien van kenmerken van de huisarts en zijn praktijk, spreekuurvorm en, in geringere mate, leeftijd huisarts samenhang vertonen met de uitstelduur van de patiënt. Patiënten stelden in praktijken met afspraakspreekuur resp. bij jongere huisartsen relatief korter uit dan in praktijken met vrij spreekuur resp. bij oudere huisartsen.

Welk is nu de praktische betekenis van de bij de toetsing van de hypothesen (hoofdstuk IV) gevonden resultaten? Naast de vraagstelling of de toetsingen van de hypothesen in het voorgaande hoofdstuk significant zijn omdat ze afzonderlijk getoetst werden, merken we op dat een significant resultaat inhoudelijk niet relevant hoeft te zijn. Bij een lage hoogte van de gehanteerde associatiemaat, die statistisch significant is, kan formeel geconcludeerd worden dat de correlatie niet nul is, maar inhoudelijk betekent dit dat de gevonden correlatie weinig van nul verschilt. Het voorspellen van de ene variabele uit de andere variabele zal dan weinig succes hebben. De tabellen in hoofdstuk IV, die een significant resultaat hebben, waarbij de gehanteerde associatiemaat Kendall's Tau een lagere waarde heeft dan 0,1 hebben inhoudelijk géén of slechts een beperkte betekenis.

Een van de belangrijkste doelstellingen van het onderzoek was na te gaan in hoeverre kenmerken van de huisarts en zijn praktijk samenhang 
vertonen met de uitstelduur van de patiënt. Uit de multipele regressieanalyse en de contrastgroepenanalyse blijkt dat de variabelen spreekuurvorm en leeftijd van de huisarts samenhang vertonen met de uitstelduur.

Bij nadere beschouwing van deze twee variabelen merken we op dat: - ten aanzien van de spreekuurvorm, patiënten met hartklachten (Kendall's Tau $\mathrm{C}=-.32$ ) en gezwellen (Kendall's Tau $\mathrm{C}=-.18$ ) in praktijken met afspraakspreekuur korter uitstelden dan in praktijken met vrij spreekuur (Zie bijlage II, tabel 4.4.3.9. en 4.4.3.10.). Huisartsen in praktijken met vrij spreekuur dienen bij deze klachten, die op een ernstige aandoening kunnen duiden, alert te zijn op ongewenst lang uitstel. De consistent gevonden negatieve Kendall's Tau in de onderzochte groepen (Zie bijlage II, tabel $4.4 .3 .1 \mathrm{t} . / \mathrm{m}$. 4.4.3.11.) vormen een aanduiding dat het verband tussen vrij spreekuur en afspraakspreekuur eerder in tegenovergestelde richting ligt. Dit werd in hoofdstuk $\mathrm{V}$ nader onderzocht waarbij met behulp van multipele regressieanalyse en contrastgroepenanalyse bleek dat patiënten in praktijken met afspraakspreekuur korter uitstelden dan in praktijken met vrij spreekuur.

- ten aanzien van de leeftijd van de huisarts, patiënten met huidklachten (Kendall's Tau $\mathrm{C}=.22$ ) en klachten van de luchtwegen (Kendall's Tau $\mathrm{C}=.19$ ) bij oudere huisartsen $(\geqslant 40 \mathrm{jr}$.) langer uitstelden dan bij jongere huisartsen $(<40$ jr.) (Zie bijlage II, tabel 4.4.5.6. en 4.4.5.5.). De consistentie van de positieve correlaties (Kendall's Tau) in de onderzochte groepen (Zie bijlage II, tabel 4.4.5.1. t. $/ \mathrm{m}$. 4.4.5.6.) vormen een aanduiding dat patiënten bij oudere huisartsen langer uitstelden dan bij jongere huisartsen. Deze bevinding werd in hoofdstuk $\mathrm{V}$ met behulp van de multipele regressieanalyse en de contrastgroepenanalyse bevestigd.

Bij vergelijking van de resultaten van de toetsingen in hoofdstuk IV en de analyses in hoofdstuk $\mathrm{V}$ blijkt dat ten aanzien van de variabelen stad/platteland en som./psych. arts, bij de toetsingen van de hypothesen $\mathrm{V}$ en $\mathrm{X}$ en de multipele regressieanalyse wèl samenhang met de uitstelduur aantoonbaar is, en bij de contrastgroepenanalyse deze samenhang met de uitstelduur niét aantoonbaar is. Mogelijk spelen interactie-effecten ten gevolge van de hoge correlaties tussen de variabelen spreekuurvorm, stad/platteland, som./psych. arts en patiëntenaantal hierbij een rol. Het resultaat van de toetsingen van de hypothesen $\mathrm{V}$ en $\mathrm{X}$ wordt niet bevestigd. 


\subsection{SAMENVATTING}

Kenmerken van de klacht werden in hun samenhang beschouwd en geven aanleiding tot invoering van het begrip urgentie van de klacht. Klachten die op een ernstige aandoening duiden resp. klachtenpatronen mèt pijn resp. overwegend somatische klachten, worden door de patiënt doorgaans als meer urgent ervaren dan klachten die niét op een ernstige aandoening duiden resp. klachtenpatronen zònder pijn resp. overwegend psychische klachten.

Via multipele regressieanalyse werd gepoogd de variantie in de afhankelijke variabele (de uitstelduur) te verklaren. Het percentage totaal verklaarde variantie is $11 \%$. Dit is niet hoog te noemen. Het grootste deel van de variantie in de uitstelduur kan dus niet verklaard worden door deze set van onafhankelijke variabelen. Drie variabelen springen eruit en vertonen een duidelijke samenhang met de uitstelduur, namelijk de urgentiegraad van de klacht, het geslacht van de patiënt en de spreekuurvorm. De variabelen patiëntenaantal en samenwerkingsverband vertonen géén samenhang met de uitstelduur van de patiënt. De overige zeven variabelen geven slechts een geringe samenhang te zien.

Bij de contrastgroepenanalyse werd onderzocht welke onafhankelijke variabelen zouden leiden tot groepen, die maximaal zouden verschillen in gemiddelde van de uitstelduur. De eerste splitsingen werden teweeggebracht door de urgentiegraad van de klacht. Ook bij deze methode vertoont de urgentiegraad van de klacht de grootste samenhang met de uitstelduur van de patiënt, op afstand gevolgd door het geslacht van de patiënt en de spreekuurvorm. Van minder belang voor de verklaring van de variantie in de uitstelduur zijn de variabelen leeftijd huisarts en leeftijd patiënt. De variabelen ervaring met de klacht, opleiding patiënt en patiënt-arts contacten hebben slechts een geringe betekenis voor de verklaring van de variantie in de uitstelduur. De variabelen stad/ platteland, som./psych. arts, patiëntenaantal en samenwerkingsverband vertonen géén samenhang met de uitstelduur.

De resultaten van de multipele regressieanalyse en de contrastgroepenanalyse bleken in grote lijnen met elkaar in overeenstemming te zijn. Gegeven de uitkomsten van de multipele regressieanalyse en de contrastgroepenanalyse kan gesteld worden dat:

- de urgentiegraad van de klacht een duidelijk verband heeft met de uitstelduur van de patiënt. Een hoge resp. lage urgentiegraad vertoont samenhang met een korte resp. lange uitstelduur. 
- het geslacht en de leeftijd van de patiënt eveneens samenhang vertonen met de uitstelduur, waarbij een oudere leeftijd ( $\geqslant 46$ jr.) resp. vrouwelijk geslacht samengaat met een langere unitstelduur, en een jongere leeftijd (17-45 jr.) resp. mannelijk geslacht samengaat met een kortere uitstelduur.

- ten aanzien van kenmerken van de huisarts en zijn praktijk de spreekuurvorm en, in geringere mate, de leeftijd van de huisarts samenhang vertonen met de uitstelduur van de patiënt. Patiënten stelden in praktijken met afspraakspreekuur resp. bij jongere huisartsen $(<40 \mathrm{jr}$.) relatief korter uit dan in praktijken met vrij spreekuur resp. bij oudere huisartsen $(\geqslant 40 \mathrm{jr}$.). 
Nadere analyse van patiënten die langer dan drie weken uitstelden en bespreking van de resultaten

\subsection{INLEIDING}

In het voorgaande hoofdstuk werd met behulp van multipele regressieanalyse en contrastgroepenanalyse gepoogd de variantie in de afhankelijke variabele te verklaren. Voor de niet-methodologisch geinteresseerde lezer volgt hier een korte samenvatting.

Allereerst een enkel woord over een nieuwe variabele: de urgentiegraad van de klacht. Ter reductie van het aantal variabelen werden de drie kenmerken van de klacht, namelijk of de klacht al of niet op een ernstige aandoening duidt, of de klacht al dan niet gepaard gaat met pijn en of de klacht overwegend somatisch of psychisch van aard is, samen genomen tot één variabele de urgentiegraad van de klacht.

Via multipele regressieanalyse en contrastgroepenanalyse bleek dat:

a. De urgentiegraad van de klacht het grootste deel van de variantie in de uitstelduur verklaart;

b. Het geslacht en de leeftijd van de patiënt variantie van enige betekenis in de uitstelduur verklaren, waarbij geslacht voornamelijk bij lage urgentiegraden en leeftijd van de patiënt voornamelijk bij hoge urgentiegraden;

c. De spreekuurvorm en de leeftijd van de huisarts variantie in de uitstelduur verklaren bij lage en gemiddelde urgentiegraden van de klacht. Het percentage totaal verklaarde variantie was $11 \%$. Het grootste deel van de variantie in de uitstelduur kon dus niet verklaard worden door deze set van onafhankelijke variabelen.

In dit hoofdstuk volgt een nadere analyse van de patiënten die langer dan drie weken uitstelden, warna in een volgende paragraaf de resultaten besproken worden.

\subsection{NADERE ANALYSE VAN DE PATIENTEN DIE LANGER DAN DRIE WEKEN UITSTELDEN}

In de nu volgende analyse worden de vijf onafhankelijke variabelen, die 
een deel van de variantie in de uitstelduur verklaren (zie inleiding van dit hoofdstuk), en de afhankelijke variabele in hun samenhang beschouwd. Ten aanzien van de afhankelijke variabele wordt hierbij de uitstelduur geanalyseerd voor zover deze langer dan drie weken bedraagt. Onze belangstelling ging speciaal naar deze langere uitstelduur uit, omdat vooral bij klachten met een hoge urgentiegraad een uitstelduur langer dan drie weken reden geeft tot bezorgdheid.

Onderzocht werd nu allereerst het percentage patiënten dat langer dan drie weken uitstelde, onderscheiden naar urgentiegraad van de klacht en leeftijd en geslacht van de patiënt (Zie tabel 6.2.1., uitgewerkt in figuur $15)$.

Tabel 6.2.1. Percentage patiënten dat langer dan drie weken uitstelde, naar urgentiegraad van de klacht en leeftijd en geslacht van de patiënt.

\begin{tabular}{ccccc}
\hline $\begin{array}{l}\text { Urgentie- } \\
\text { graad } \\
\text { klacht }\end{array}$ & $\begin{array}{c}\text { Oudere } \\
\text { vrowwen } \\
\%\end{array}$ & $\begin{array}{c}\text { Jongere } \\
\text { vrouwen } \\
\%\end{array}$ & $\begin{array}{c}\text { Oudere } \\
\text { mannen } \\
\%\end{array}$ & $\begin{array}{c}\text { Jongere } \\
\text { mannen } \\
\%\end{array}$ \\
\hline 3 & $42(\mathbb{N}=45)$ & $46(\mathrm{~N}=122)$ & $41(\mathrm{~N}=27)$ & $26(\mathrm{~N}=47)$ \\
4 & $43(\mathrm{~N}=72)$ & $34(\mathrm{~N}=131)$ & $33(\mathrm{~N}=46)$ & $22(\mathrm{~N}=74)$ \\
5 & $31(\mathrm{~N}=105)$ & $28(\mathrm{~N}=238)$ & $28(\mathrm{~N}=107)$ & $14(\mathrm{~N}=182)$ \\
6 & $27(\mathrm{~N}=82)$ & $18(\mathrm{~N}=121)$ & $21(\mathrm{~N}=66)$ & $18(\mathrm{~N}=121)$ \\
7 & $18(\mathrm{~N}=22)$ & $14(\mathrm{~N}=43)$ & $22(\mathrm{~N}=23)$ & $9(\mathrm{~N}=44)$ \\
\hline Totaal & $33(\mathrm{~N}=326)$ & $30(\mathrm{~N}=655)$ & $28(\mathrm{~N}=269)$ & $17(\mathrm{~N}=468)$ \\
\hline
\end{tabular}

Uit tabel 6.2.1., uitgewerkt in figuur 15, blijkt dat bij klachten met een lagere urgentiegraad een hoger percentage patiënten langer dan drie weken uitstelde dan bij klachten met een hogere urgentiegraad. Deze percentages blijken bij ouderen gemiddeld hoger te zijn dan bij jongeren. Ten aanzien van het geslacht waren deze percentages, de hoogste urgentiegraad (7) uitgezonderd, bij vrouwen gemiddeld hoger dan bij mannen. Ouderen stelden in vergelijking met jongeren bij klachten met een hoge urgentiegraad, en vrouwen in vergelijking met mannen bij klachten met een lage urgentiegraad, relatief meer frequent langer dan drie weken uit. Jongere mannen stelden relatief weinig langer dan drie weken uit.

Onze speciale belangstelling ging uit naar de patiënten, die bij klachten met een hoge urgentiegraad langer dan drie weken uitstelden alvorens de 


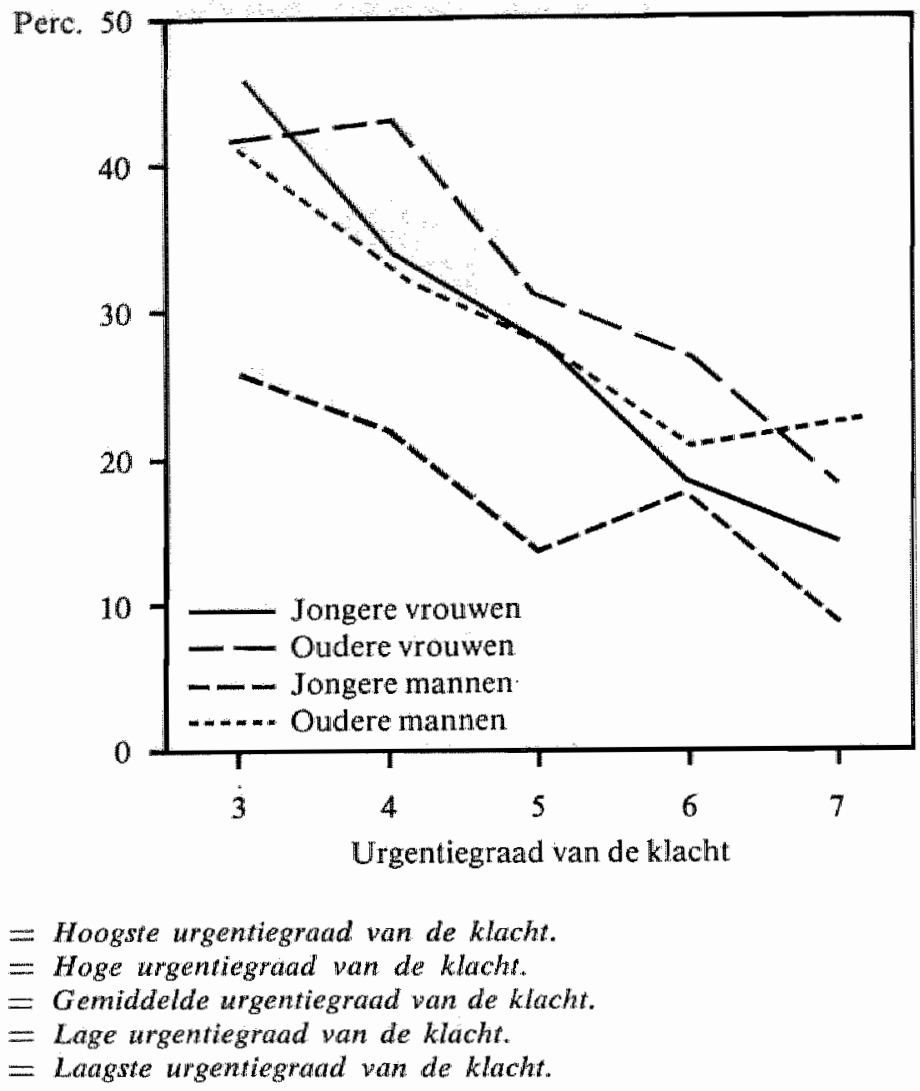

Fig. 15. Percentage patiënten dat langer dan drie weken uitstelde, natar urgentiegraad van de klacht en leeftijd en geslacht van de patient.

huisarts te raadplegen. Vooral deze patiënten geven ons reden tot bezorgdheid. Ten aanzien van dit ongewenst lang uitstel zijn wij geïnteresseerd in de vraag bij welk type patiënt en welk type klacht dit ongewenst uitstel optreedt. Wat is bij deze patiënten de reden van komst naar de huisarts?

Daartoe werd de onderzoekpopulatie ingedeeld in:

a. De patiënten die bij klachten met de hoge urgentiegraad 7, langer dan drie weken uitstelden;

b. Alle overige onderzochte patiënten.

Van beide populaties werd aan de hand van kenmerken van de patiënt 
en kenmerken van de huisarts en zijn praktijk, de samenstelling bepaald. Hierbij bleek dat oudere patiënten $(\geqslant 46$ jr.) relatief meer bij klachten met een hoge urgentiegraad (7) langer dan drie weken uitstelden dan jongere patiënten (17-45 jr.) (Zie tabel 6.2.2.). Ten aanzien van de overige onderzochte variabelen was geen verschil tussen beide populaties aantoonbaar. Dit bevestigt uiteraard datgene wat in hoofdstuk $\mathrm{V}$ over urgentiegraad is aangetoond.

Tabel 6.2.2. Verband tussen patiënten die bij klachten met een hoge urgentiegraad (7) langer dan drie weken uitstelden en de leefijid van de patiënt.

\begin{tabular}{|c|c|c|c|}
\hline & $\begin{array}{c}17-45 \mathrm{jr} . \\
\%\end{array}$ & $\geqslant \underset{\%}{46 \mathrm{jr}}$ & $\begin{array}{c}\text { Totaal } \\
\%\end{array}$ \\
\hline $\begin{array}{l}\text { Alle overige } \\
\text { onderzochte patiënten }\end{array}$ & 95 & 92 & 94 \\
\hline $\begin{array}{l}\text { Patiënten die bij klachten met } \\
\text { een hoge urgentiegraad ( } 7 \text { ) } \\
\text { langer dan drie weken uitstelder }\end{array}$ & 5 & 8 & 6 \\
\hline Totaal & $100(\mathrm{~N}=1133)$ & $100(\mathbb{N}=606)$ & $100(\mathrm{~N}=1739)$ \\
\hline
\end{tabular}

Chi-kwadraat $=4,92 \quad \mathbf{P}<0,1$

Ten aanzien van de klacht bleek dat van de zestig patiënten die hun huisarts consulteerden wegens een knobbeltje, vijftien patiënten $(25 \%)$ langer dan drie weken uitstelden. Dit percentage is hoog te noemen. Hierbij merken we op dat ook ,onschuldige knobbeltjes" als een vetknobbeltje of een ganglion in deze groep werden gerangschikt.

Ten aanzien van de vierenvijftig patiënten die hun huisarts consulteerden wegens de klacht pijn bij plassen, stelden zeven patiënten $(13 \%)$ langer dan drie weken uit. Het is opmerkelijk dat bij deze goed te herkennen klacht nog altijd zeven patiënten langer dan drie weken wachtten alvorens hun huisarts te raadplegen. Dachten deze mensen misschien dat hun klachten vanzelf zouden overgaan? Waarschijnlijk is nog een onvoldoend aantal mensen bekend met de mogelijk ernstige gevolgen van een verwaarloosde urineweginfectie (iets dergelijks is ook waarneembaar bij hypertensie of een beginnende diabetes mellitus).

Van de eenenveertig patiënten die hun huisarts consulteerden wegens de klacht pijn op de borst, stelden drie patiënten (7\%) langer dan drie 
weken uit. Waarom stelden deze drie patiënten zo lang uit? Dachten zij misschien dat hun klachten wel mee zouden vallen?

Als reden van consultatie van de huisarts noemden patiënten, die bij klacliten met een hoge urgentiegraad langer dan drie weken uitstelden, relatief vaker dat zij gestuurd werden door anderen of dat zij de huisarts consulteerden voor een andere klacht. Relatief minder vaak werden door deze patiënten de redenen ongerustheid of hinder genoemd.

Resumerend kan gesteld worden dat nog altijd patiënten met klachten, die op een ernstige aandoening kunnen duiden, langer dan drie weken wachten alvorens hun huisarts te raadplegen. Vooral bij oudere patiënten dient de huisarts alert te zijn op ongewenst lang uitstel bij klachten die op een ernstige aandoening kunnen duiden. De onderzochte variabelen ten aanzien van kenmerken van de huisarts en zijn praktijk vertoonden geen verband met dit ongewenst lang uitstel van de patiënten. Ten aanzien van de klacht is een goede voorlichting noodzakelijk, temeer daar slechts een gering percentage patiënten, die bij klachten met een hoge urgentiegraad langer dan drie weken uitstelden, ongerustheid opgaf als reden van komst naar de huisarts.

\subsection{BESPREKING VAN DE RESULTATEN}

Zoals reeds in de inleiding van deze dissertatie gezegd, was de opzet van het onderzoek meer inzicht te verkrijgen in factoren die de uitstelduur bepalen. In het voorgaande is uiteengezet in hoeverre antwoord verkregen is op de geformuleerde vraagstelling. In deze paragraaf wordt getracht na te gaan, welke implicaties de gevonden resultaten kunnen hebben voor de dagelijkse praktijk.

Allereerst echter enkele kritische opmerkingen over het onderzoek zelf:

a. Een beperking in dit onderzoek is, dat de samenwerkingsverbanden niet uitgebreid konden worden met groepspraktijken en gezondheidscentra. Op het moment van onderzoek was in deze regio een te gering aantal hiervan werkzaam.

b. Een andere beperking is, dat het onderzoek plaatsvond in en rondom de stad Maastricht, waardoor plaatselijke kenmerken misschien invloed op het onderzoek hebben uitgeoefend. Onderzoek over een grotere regio, liefst met een landelijk karakter, zou hier de voorkeur hebben verdiend, maar is om praktische reden nagelaten. 
c. Aan het onderzoek werd deelgenomen door tweë̈ntwintig huisartsen. Per huisarts werden honderd consulten geregistreerd, wat voor veel deelnemende huisartsen, naast hun dagelijkse werk, een grote belasting betekende. Niet ontkend kan worden dat sommige wel gewenste, maar zeer gedetailleerde analyses daardoor niet gemaakt konden worden. Hoewel vanuit puur onderzoeksoogpunt een grotere steekproef van artsen en patiënten met nieuwe klachten te prefereren zou zijn geweest, lijkt het resulterende aantal waarnemingen tot een goede analyse te hebben kunnen leiden.

d. Het onderzoek vond plaats gedurende vier weken in de maand september, waardoor seizoensinvloeden mogelijk een rol hebben gespeeld. Onderzoek gedurende één jaar was te prefereren geweest.

e. Als beperking van dit onderzoek geldt ook, dat de onderzoekpopulatie bestond uit mensen, die besloten hadden de dokter uiteindelijk toch te raadplegen. Patiënten die als het ware oneindig uitstellen, en dus de dokter niet raadplegen, komen in dit onderzoek niet voor.

Tenslotte merken we op dat dit onderzoek over ,nieuwe klachten', geen exacte weerspiegeling geeft van het doorsnee spreekuurbezoek. Bij de onderzochte ,nieuwe klachten' zullen verhoudingsgewijs meer somatische klachten aanwezig zijn (in ons onderzoek was dit $68 \%$ van alle ,nieuwe klachten"). Zo hebben we gemerkt tijdens een spreekuur van veertig patiënten dat vijftien patiënten $(37 \%)$ kwamen met overwegend somatische klachten en vijfentwintig patiënten $(63 \%)$ met overwegend psychische klachten, nervositas of om een praatje te maken. In plaats van onderzoek over ,nieuwe klachten' zou uitbreiding van het onderzoek over zoveel mogelijk klachten waarvoor de huisarts geraadpleegd wordt, wenselijk zijn. Elk onderzoek is een compromis tussen het ideaal wenselijke en het praktisch mogelijke, hetgeen in het bijzonder geldt voor onderzoek in huisartsenpraktijken.

De bevindingen van ons onderzoek vormen een bevestiging van de overigens schaars aanwezige - bevindingen uit eerder verricht onderzoek.

Het percentage totaal verklaarde variantie is $11 \%$. Dit is niet hoog te noemen. Het betekent dat het grootste deel van de variantie in de afhankelijke variabele niet verklaard kan worden door deze set onafhankelijke variabelen.

De consultatie van de huisarts is een hele complexe gebeurtenis. 
Wat kan mensen ertoe brengen hun huisarts niét te consulteren resp. een consult uit te stellen? Hiervoor kunnen vele redenen aanwezig zijn.

Angst kan leiden tot een langere uitstelduur. De patiënt kan angst hebben voor een pijnlijke behandeling, maar ook angst om dood te gaan, of angst voor verwijzing naar een specialist die misschien een kwaal bij hem ontdekt (kanker, hartkwaal). Ook angst voor een onwelkom advies (stoppen met roken, geen alcohol gebruiken) kan de patiẻnt doen besluiten de huisarts niet te consulteren.

Ook schaamte kan aanleiding zijn tot een langere uitstelduur van de patiënt. In de praktijk treft men herhaaldelijk een weerstand aan tegen het tonen van een gebrek. De patiënt kan een schaamte hebben wegens het anders zijn dan anderen. Zo kan er een gêne bestaan over als te groot of te klein beleefde mammae.

Het kan ook zijn dat de patiënt geen nut van het consult aân de huisarts verwacht. Dit wordt deels veroorzaakt door teleurstellende ervaringen met geneeskundige diensten in het verleden, deels door het onjuist inzicht in de mogelijkheden die de geneeskunde te bieden heeft. Een goede voorlichting is dan ook van groot belang. IEMHOFF 1979, meent dat veel geklaag van medische zijde over, uitstelgedrag' nogal moraliserend van toon is. Hij zegt: "Men is van medische zijde weleens geneigd te vergeten dat een vroegtijdige diagnose zonder te verwachten nut, de drager van de diagnose tot een patiënt maakt, wat zijn ervaringen, zijn relaties en zijn sociale kansen ongunstig kan beïnvloeden. Iemand tot een patiënt maken is soms nuttig en geboden, maar brengt steeds nadelen met zich mee; men is gestigmatiseerd".

De patiënt kan zijn ziekte als psychisch, psycho-somatisch of psychosociaal ervaren. Voor velen is eigenlijk alleen een somatische ziekte aanvaardbaar. Een psycho-somatische resp. psycho-sociale aandoening wordt beleefd als iets waar men in eerste instantie zelf wat aan kan doen.

De attitude van de huisarts kan bij de patiënt uitstelbevorderend werken. Vooral huisartsen die niet graag ,wegens een kleinigheidje worden gestoord" dienen rekening te houden met de mogelijkheid dat patiënten bij hen langer uitstellen. De patiënt kan bang zijn dat de huisarts hem voor een aansteller aanziet.

Een slechte bereikbaarheid van de huisarts kan eveneens leiden tot een langere uitstelduur van de patiënt. Deze factor is erg belangrijk bij oudere, gehandicapte mensen, die moeilijk op eigen gelegenheid naar de huisarts kunnen gaan, die eenzaam leven en een erg bezette huisarts hebben die weinig tijd vindt hen regelmatig op te zoeken. Ook lange wachttijden in de wachtkamer vallen onder deze noemer. 
Waarom consulteren mensen hun huisarts? Hiervoor zijn vele redenen te noemen (zie Brouwer en Touw-OTTEN 1974). Behalve dat patiènten hun huisarts consulteren wegens hun klacht, is de belevingsvorm van de klacht door de patiënt van groot belang. De patiënt zal bij een pijnlijke klacht vlugger geneigd zijn de hulp van de arts in te roepen, dan bij een klacht waarvan hij slechts enige hinder heeft.

Daarnaast kunnen allerlei omstandigheden en gebeurtenissen bij aanwezigheid van klachten, symptomen of andere problemen aanleiding geven tot consultatie van de huisarts.

Angst, ongerustheid en onzekerheid kunnen ertoe leiden dat een patiënt vlugger de hulp van de huisarts inroept. Uitlatingen als: ,,je hoort tegenwoordig van die rare dingen" of ,,je weet het per slot van rekening maar nooit" duiden op een ongerustheid bij de patiënt. Dikwijls worden deze gevoelens echter verzwegen. Bij een aantal patiënten zal zeker angst en dergelijke als bijkomend motief aanwezig zijn, zonder dat deze door de huisarts als zodanig worden herkend.

Het ongewoon beloop van een klacht. Tedereen heeft wel eens hoofdpijn of een spierpijn. Vele klachten staan bekend als onschuldig en redelijk voorspelbaar wat hun beloop betreft. Consultatie van de huisarts wordt pas nodig geacht, als de klacht heviger is of langer duurt dan ,normaal".

Een reeds bestaand gestoord gezondheidsgevoel. Patiënten hebben soms tijden lang vage onlustgevoelens, zonder dat daarvoor de huisarts geraadpleegd wordt. Vaak is er dan wel een vage behoefte aan hulp, maar men komt er niet toe deze in te roepen. Een min of meer toevallige gebeurtenis, die op zichzelf weinig ingrijpend hoeft te zijn, kan dan de ,trigger' zijn om de huisarts te raadplegen.

Belastende milieu-situaties (b.v. stress) kunnen leiden tot klachten respectievelijk aandoeningen die consultatie van de huisarts wenselijk maken. Dit is langzamerhand een algemeen aanvaarde zienswijze.

Klachten worden nogal eens opgespaard. Komt de patiënt uiteindelijk bij de huisarts terecht, dan krijgt de huisarts, nu de patiënt toch bij hem is, het verzoek nog even naar iets anders te kijken. Het betreft hier een aantal uiteenlopende gezondheidsproblemen, die samen leiden tot het inroepen van medische hulp.

Beïnvloeding door anderen. Raadpleging van anderen vindt meestal binnen het gezin plaats. CASSEE 1973, vond in zijn onderzoek dat meer dan $75 \%$ van de ondervraagden voordat zij met de huisarts spraken, eerst anderen over hun klachten en/of problemen hadden verteld. $\mathrm{Bij}$ meer dan de helft van de mensen, die met anderen over hun klachten hadden gesproken, was druk uitgeoefend om de arts te consulteren. 
Tenslotte kunnen nog allerlei vage redenen aanwezig zijn waarom de huisarts geconsulteerd wordt. Misschien wil iemand alleen maar wat aandacht. Of ander werk. Of weg uit de eenzaamheid. Of iets doen aan een vastgelopen huwelijk.

Bovenstaande redenen, die niet uitputtend zijn, laten zien dat mensen hun huisarts bezoeken om velerlei redenen. Lang niet altijd is de gepresenteerde klacht van de patiënt de werkelijke reden waarom de huisarts geconsulteerd wordt. Hiermee dient de huisarts rekening te houden. Herkent de huisarts dit probleem niet, dan zall de patiënt steeds weer een nieuwe klacht aanbieden, totdat het onderliggende probleem door de huisarts onderkend wordt. De vraag: „Waarom komt déze patiënt nú met déze klacht bij mij", is voor de huisarts vaak heel relevant.

Voor veel mensen, speciaal met een lagere intelligentiegraad, blijkt het consulteren van de huisarts een grote stap te zijn. De mensen hebben het gevoel alsof ze het verdere verloop van hun ziekte uit handen geven. Voor de patiënt kan het een „alles of niets” beslissing betekenen. Vaak gebruikt de patiënt eerst nog zoveel mogelijk eigen middelen (zelfmedicatie), alvorens naar de huisarts te gaan. Ter ondervanging van dit probleem zou een soort tussen-stap ingevoegd kunnen worden, waarbij de patiënt alyorens naar de huisarts te gaan de mogelijkheid wordt geboden, eerst met een deskundige (b.v. verpleegster) over zijn aandoening te spreken. Huisartsen kunnen in hun praktijkvoering daarop inspelen, door bijvoorbeeld de praktijkassistentes in grotere mate een eigen rol te laten vervullen, zoals het geven van adviezen aan de patiënt en het verrichten van tensiecontroles.

\section{De urgentiegraad van de klacht.}

De patiënten stelden bij klachten met een lage urgentiegraad relatief langer uit dan bij klachten met een hoge urgentiegraad. Dit is niet zo verwonderlijk. Toch zijn nog altijd patiënten die bij klachten met een hoge urgentiegraad langer dan drie weken wachten, alvorens de huisarts te raadplegen. In ons onderzoek bleek dat bij de meest urgente klachten (urgentiegraad 7) nog altijd gemiddeld één op zes mensen (16\%) langer dan drie weken uitstelt (Zie tabel 6.2.1.). Bij oudere mannen lopen deze aantallen op tot gemiddeld één op vier à vijf mensen (22\%). Het laagste cijfer van gemiddeld én op tien (9\%) komt voor bij jongere mannen. Speciaal oudere patiënten $(\geqslant 46$ jr.) bleken in ons onderzoek bij klachten met een hoge urgentiegraad langer dan drie weken uit te stellen. De 
huisarts doet er dus goed aan vooral bij oudere patiënten alert te zijn op ongewenst lang uitstel.

Ten aanzien van de klacht bleek dat van de onderzochte patiënten met een ,knobbeltje' nog steeds één op vier patiënten (25\%) langer dan drie weken wacht, alvorens de huisarts te raadplegen. Ten aanzien van de klacht "pijn bij plassen' resp. ,pijn op de borst" was dit percentage $17 \%$ resp. $7 \%$. Hieruit blijkt hoe essentieel goede informatie en duidelijke advisering is voor alle patiëntengroepen. De huisarts kan hieraan bijdragen door goede en vooral praktische aanbevelingen te geven door bijvoorbeeld bij urineweginfecties de patiënten erop te wijzen dat zij terug moeten komen zodra dezelfde klachten zich herhalen, en daarentegen bij een migraine aanval de patiënten erop te wijzen dat bij opnieuw optreden hiervan, hij niet metéén de hulp van de arts hoeft in te roepen, maar wel moet zorgen steeds medicamenten ter beschikking te hebben.

In het kader van wat wij urgentiegraad hebben genoemd wordt nu kort ingegaan op twee factoren: pijn en ernst.

- Pijn bleek in ons onderzoek de meest voorkomende reden $(26 \%$ van het totaal aantal redenen) te zijn, tot consultatie van de huisarts wegens een „nieuwe klacht' (Zie tabel 3.4.5.1.). Pijn heeft voor een mens een duidelijke signaalfunctie. Het is een waarschuwing dat het levend organisme van binnen uit of van buiten af bedreigd wordt. Pijn heeft duidelijk zintuiglijke eigenschappen, maar eveneens spelen emotionaliteit en gemotiveerdheid hierbij een rol. Pijn is een van de belangrijkste onlustgevoelens. Pijn is vervelend. Het is een begrijpelijke drijfveer de huisarts te consulteren. Aan pijn zijn een aantal facetten te onderscheiden die ieder samenhang kunnen vertonen met de uitstelduur van de patiënt.

Bij pijn gaat het vooral om de pijntolerantie en om de totale pijnbeleving. Deze worden krachtig beïnvloed door factoren en omstandigheden die zich grotendeels of geheel aan objectieve maatstaven onttrekken. De pijnbeleving wordt sterk bepaald door de perceptie en de interpretatie van de patiënt en de betekenis die de pijn voor hem heeft. Ongevoeligheid voor pijn ondanks letsel en spontane pijn bij afwezigheid van letsel, zijn twee uitersten van het hele spectrum van de pijnbeleving. Metz 1975, is van mening dat het onvermogen de pijnbeleving onder woorden te brengen in scherp contrast staat tot de helderheid waarmee de diagnostiek een afwijking kan lokaliseren, haar aard kan bepalen en haar therapeutisch kan behandelen.

Pijn kan langzaam beginnen of acuut aanwezig zijn. Acute ernstige pijn vereist meestal acute maatregelen. De uitstelduur van de patiënt zal 
hierbij doorgaans kort zijß. Bij de langzaam beginnende pijnen speelt de intensiteit en duur van de klacht een belangrijke rol op het inroepen van de hulp van de arts. Echte chronische pijnen komen in ons onderzoek niet voor omdat bij chronische pijnen niet gesproken kan worden van een ,nieuwe klacht'.

De lokalisatie van de pijn aangeven is voor de patiënt minder moeilijk dan zijn pijnbeleving verwoorden. De pijn zit waar hij deze voelt. De lokalisatie van de pijn kan een rol spelen bij het inroepen van de hulp van de arts. Pijn in de hartstreek kan de patiënt als levensbedreigend ervaren en hem doen besluiten de arts snel te raadplegen.

Pijn kan voor de patiënt een legitimatie zijn de drempel tot consultatie van de huisarts te overschrijden. De patiënt kan ook erop uit zijn, met behulp van pijn, ten aanzien van de ernst van zijn klachten geen twijfel te laten bestaan. In beide gevallen kan pijn de uitstelduur bekorten. ZisorowsKI 1958, bestudeerde in zijn klassiek geworden onderzoek bij 87 mannen met hernia nuclei pulposi en ruggemerglaesies, de culturele bepaaldheid van de pijnbeleving. Hij constateerde dat Amerikaanse patiënten van Italiaanse en van Joodse origine zich kenmerken door een emotioneel open reactie op pijn en snel geneigd waren hun ongemak onder woorden te brengen. De Italianen waren meer betrokken bij het ongemak van de pijn, terwijl de Joodse Amerikanen meer geïnteresseerd waren in de eventuele consequenties ten aanzien van hun gezondheidstoestand. De in het onderzoek betrokken Ieren en ,Old-Americans' klaagden totaal niet, brachten amper hun ongemak naar voren en namen een vrij stoïcijnse houding aan.

Brouwer en ToUw-OTTEN 1974, vonden bij een onderzoek in drie huisartsenpraktijken, met 300 ,nieuwe' ziektegevallen, dat pijn een grote rol speelt bij de vraag of men de hulp van de arts zal inroepen, maar op zichzelf hoeft pijn daarvoor geen reden te zijn. De grote omvang van de zelfmedicatie met pijnstillende middelen wijst daar wel op.

Uit bovenstaande blijkt hoe belangrijk het is dat de huisarts rekening houdt met de betekenis van de klacht voor de patiënt. Hoe denkt de patiënt zelf over zijn klacht? Ten aanzien van de klacht, hoofdpijn" dient de huisarts zich bijvoorbeeld af te vragen of de patiënt hem consulteert wegens de pijn, of omdat de patiënt angst heeft voor een hersentumor. Bij de hulpverlening kan de huisarts dan beter inspelen op de verwachtingen van de patiënt.

- In dit onderzoek bleek dat patiënten bij klachten die algemeen bekend staan als mogelijke aanwijzingen voor een ernstige ziekte korter 
uitstelden, dan bij klachten die niet algemeen bekend staan als mogelijke aanwijzingen voor een ernstige ziekte.

Ten aanzien van het uitstel van patiënten bij klachten, die algemeen bekend staan als mogelijke aanwijzingen voor een ernstige aandoening, kan onderscheid gemaakt worden in:

a. De patiënt heeft géén weet van de ernst van de aandoening. Bijvoorbeeld een knobbeltje aan het oor of onregelmatig vaginaal bloedverlies. Een juiste opvoeding en een goede gezondheidsvoorlichting kan hierin veel verbetering aanbrengen.

b. De patiënt heeft wèl weet van de ernst van zijn aandoening, maar denkt dat het wel mee zal vallen. Heeft de patiënt bijvoorbeeld pijn op de borst dan kan hij denken dat de klachten dadelijk wel zullen verdwijnen. Hij denkt, het zal wel niet zo erg zijn. De patiënt redeneert als het ware naar zich toe. Voor deze patiënten is de wens de vader van de gedachte.

c. De patiënt berust in zijn situatie en komt er niet toe een arts te raadplegen. Oudere mensen zijn vaak van mening dat lichamelijke gebreken bij hun leeftijd horen. Een zekere fatalistische instelling is bij hen waarneembaar. Eenzelfde instelling zien we ook bij patiënten met een lage intelligentiegraad, waarbij een zekere apathie is vast te stellen ook bij klachten duidend op een ernstige aandoening, bijvoorbeeld kinderen met ernstige oogafwijkingen die desondanks niet bij de arts komen. Eenzelfde gedrag zien we soms ook in streng orthodoxe bevolkingsgroepen. Ziekte wordt door hen beschouwd als uiting van Gods wil, en deze heeft men te aanvaarden.

d. De patiënt vindt het niet meer de moeite waard om medische hulp in te roepen. Sommigen vinden het leven zelf niet meer de moeite waard. Ze geloven er niet meer in. Zijn deze patiënten, die geen perspectief meer in het leven zien, bijvoorbeeld aan drugs verslaafd, dan zijn zij nauwelijks nog te motiveren hiermee te stoppen. Deze groep mensen vormt een toenemend probleem, met name wat betreft suicide. Uit gegevens van de stichting medische registratie in Utrecht blijkt dat tussen 1970 en 1976 het aantal opnames in algemene ziekenhuizen ten gevolge van pogingen tot zelfdoding met $70 \%$ is gestegen.

CASSEE 1973, constateerde dat bij uitstellen de noodzaak om de hulp van de arts in te roepen een belangrijke rol speelt. De patiënt stelt langer uit naarmate de klachten minder ernstig zijn, of als minder ernstig ervaren worden.

Ook ROSENSTOCK 1966, heeft de gedachtengang nader uitgewerkt, dat 
mensen eerder geneigd zijn tot handelen op het gebied van ziekte en gezondheid, naarmate zij ziekte als ernstiger ervaren.

\section{Leeftijd en geslacht van de patiënt.}

Ten aanzien van de demografische variabelen leeftijd en geslacht van de patiënt bleek dat ouderen in vergelijking met jongeren, en vrouwen in vergelijking met mannen langer uitstelden. Speciaal oudere vrouwen zijn geneigd langer uit te stellen.

PpLANZ 1969, constateerde dat vrouwen meer medicijnen op eigen initiatief kopen dan mannen. Deze grotere zelfmedicatie bij vrouwen kan samenhang vertonen met een langere uitstelduur. CASSEE 1973 en JESSEN 1974, rekenden de leeftijd van de patiënt tot de basisvariabelen, die een speciale invloed hebben op de uitstelduur. Beide auteurs kwamen tot de bevinding dat vrouwen langer uitstelden dan mannen, waarbij Cassee vaststelde dat vrouwen vaker als reden voor hun uitstel noemden dat het hun niet mogelijk was om tijdig naar de dokter te gaan.

In het voorgaande werd vermeld dat bejaarden geneigd zijn een klacht te beschouwen als iets wat bij het ouder worden hoort. $\mathrm{Zij}$ raadplegen hun huisarts niet zo vlug. Gezien dit gegeven doet de huisarts er goed aan bij ouderen en vooral bij oudere vrouwen alert te zijn op ongewenst lang uitstel. Goede voorlichting en vooral een goede arts-patiënt relatie kan waarschijnlijk veel ongewenst uitstel, bijvoorbeeld bij onregelmatig vaginaal bloedverlies, voorkomen.

\section{De spreekuurvorm.}

De resultaten van dit onderzoek vormen een aanwijzing dat patiënten bij klachten met een lage of gemiddelde urgentiegraad, in praktijken met afspraakspreekuur overwegend korter uitstellen dan in praktijken met vrij spreekuur. Dit zou een extra argument kunnen zijn voor het houden van afspraakspreekuren. Ten aanzien van klachten met een hoge urgentiegraad was tussen patiënten, in praktijken met vrij resp. afspraakspreekur, geen verschil in uitstelduur aantoonbaar.

Een mogelijke verklaring voor een langere uitstelduur van patiënten in praktijken met vrij spreekuur kan zijn dat:

a. Patiënten het vervelend vinden dat ze moeten wachten. Bovendien weet de patiënt meestal niet hoelang hij zal moeten wachten. Het kan zijn dat de patiënt het vervelend vindt door andere patiënten gezien te worden. De patiënten in de wachtkamer zouden zich kunnen afvragen wat er an de hand is. 
b. Patiënten in praktijken met vrij spreekuur elk moment op hun beslissing, de huisarts te raadplegen, kumnen terugkomen. Dit kan uitstelbevorderend werken. Bij afspraakspreekuren is dit minder mogelijk. Men kan zich voorstellen dat de patiënt, die een volle wachtkamer binnenkomt, besluit een andere dag terug te komen. Zijn de klachten na enkele dagen beduidend verminderd, dan is het zeer goed mogelijk dat de patiënt besluit de arts niét te consulteren. In praktijken met afspraakspreekuur kan men zich voorstellen dat de patiënt een afspraak maakt en eerst over twee dagen bij de arts terecht kan. Ook hier bestaat de mogelijkheid dat de klachten na deze twee dagen beduidend verminderd zijn. Echter omdat de patiënt de afspraak nu eenmaal heeft gemaakt, zal hij de arts tòch consulteren. Dit kan leiden tot een kortere uitstelduur van patiënten in praktijken met afspraakspreekuur.

KesSEl en SHEPHERD 1965, constateerden in Engeland dat mensen die zelden of nooit de huisarts consulteerden, kritischer waren ten opzichte van de dienstverlening van de huisarts, zoals wachttijden.

Bovenstaande maakt aannemelijk dat patiënten in praktijken met vrij spreekuur langer uitstellen dan in praktijken met afspraakspreekuur. Het is inzichtelijk dat de factoren, genoemd onder a en b, meer gelden naarmate de praktijken groter zijn. Huisartsen met grote praktijken, die vrij spreekuur hebben, dienen alert te zijn op ongewenst uitstel. Het is denkbaar dat patiënten wegens de lange wachttijden een visite aanvragen, terwijl dit niet zo nodig is.

\section{De leeftijd van de huisarts.}

De resultaten van dit onderzoek vormen, in mindere mate dan bij de spreekuurworm, een aanwijzing dat patiënten bij huisartsen $\geqslant 40$ jaar langer uitstellen dan bij huisartsen $<40$ jaar. Een mogelijke verklaring hiervoor kan zijn dat oudere huisartsen een groter aantal jaren in hun praktijk werkzaam zijn. Vaak hebben zij al de ouders van de patiënt onder hun behandeling gehad. Gedurende een groot aantal jaren hebben zij hun stempel kunnen drukken op het gedrag van hun patiënten. Daarom is denkbaar dat patiënten bij oudere huisartsen meer inspelen op de veronderstelde wensen en verwachtingen van de dokter, die ze al zo lang kennen. Opgemerkt wordt dat in dit onderzoek de samenhang tussen de uitstelduur van de patiënt en structurele variabelen van de huisarts en zijn praktijk als leeftijd van de arts en spreekuurvorm, slechts in beperkte mate aanwezig is.

CASSEE 1973, stelt ten aanzien van de persoonsvariabelen van de huisarts 
vast, dat van de vijf perceptiedimensies van het gedrag van de huisarts er drie uit de analyse zijn weggevallen (nl. informatief, afwerend en diffuus optreden) en dat de overige twee (instrumenteel en communicatief optreden) een niet-significante partiële correlatie met uitstel hebben. Niet zozeer de perceptie van het specifielke gedrag van de huisarts, als wel de perceptie van zijn vaardigheden, zijn kennis, zijn verwachtingen ten aanzien van de patiënt en zijn beroepsopvatting zijn van invloed.

J/ACOBS e.a. 1979 en MEYBOOM 1979, zijn ten aanzien van de artspatiënt contacten van mening dat de invloed van structurele variabelen wordt overschat, die van persoonsvariabelen onderschat. De huisarts dient zich dus te realiseren dat zijn attitude uitstel kan bevorderen. Verder onderzoek over de samenhang tussen de taakopvatting van de huisarts en de uitstelduur van de patiënt is gewenst.

Blijkbaar is de wijze van praktijkvoering van de huisarts toch van invloed op de uitstelduur van de patiënt. Echter het functioneren van de huisarts vertoont vooral de laatste decennia een grote variatie. Vroeger was het de patiënt vrij duidelijk wat hij van de huisarts kon verwachten. Tegenwoordig is dit veel minder het geval. De ene huisarts zal in zijn werk meer psychisch geöriënteerd zijn, veel gesprekken voeren en de patiënten steeds terug laten komen, terwijl de andere huisarts meer somatisch geöriënteerd is, minder gesprekken voert en de patiënt meestal zelf laat beslissen of hij terug moet komen. Deze verschillen in praktijkvoering kunnen een zekere onrust en onzekerheid bij de mensen veroorzaken. Nader onderzoek gericht op een zo volledig mogelijk inzicht in de werkwijze van de huisarts is zeker gewenst.

Gesteld kan worden dat in het complexe gebeuren van het consulteren van de huisarts veel factoren een rol spelen. Ten aanzien van dit consulteren, in al zijn facetten, werd slechts een klein stukje van de sluier opgetild, waarbij ik bij herhaling heb ervaren dat beantwoording van éen vraag tegelijkertijd diverse andere vragen oproept. 


\section{Samenvatting}

Als huisarts constateert men dat de patiënten lang niet altijd op het juiste tijdstip komen wanneer ze de huisarts raadplegen. Enerzijds zijn er nog altijd patiënten die b.v. met een ,knobbeltje in de borst', of bij ,ophoesten van bloed' of bij , anaal bloedverlies', te lang wachten alvorens hun arts te raadplegen. Anderzijds zijn er ook patiënten die, gezien de aard van de klachten, de hulp van de huisarts onnodig of onnodig vroeg inroepen. Wil men hier verbetering in aambrengen dan moet men eerst de oorzaken van dit inadequaat uitstel trachten op te sporen. Ligt de oorzaak grotendeels bij de patiënt b.v. angst, dan zal een goede voorlichting al veel verbetering kunnen brengen. Mogelijk echter is ook, dat de oorzaak voor een belangrijk deel ligt bij de arts en diens wijze van praktijkvoering. Is, gezien tegen de achtergrond van dit lange uitstel, aan een bepaalde wijze van praktijkvoering de voorkeur te geven? Hebben bijvoorbeeld samenwerkingsverbanden en afspraakspreekuren invloed op de uitstelduur, en zo ja, in hoeverre? Alvorens tot veranderingen in de praktijkvoering over te gaan, lijkt onderzoek hieromtrent aangewezen. Bovenstaande overwegingen vormden de aanleiding tot het bestuderen van de vraag of, en zo ja, in hoeverre, samenhang aanwijsbaar is tussen uitstelduur enerzijds en kenmerken van de patiënt, van de klachten en van de arts, inclusief diens praktijk, anderzijds.

Hoofdstuk I bevat, naast een beschrijving van de probleemstelling, de formulering van de hypothesen. Wat betreft de kenmerken wan de patiênt werd, in navolging van CASSEE 1973, gekozen voor drie structurele variabelen: leeftijd, geslacht en opleiding. Daarnaast werd de frequentie van doktersbezoek, de woonplaats en de eventuele ervaring van de patiênt met de klacht, in het onderzoek betrokken. Het lijkt voor iedereen aannemelijk dat kenmerken van de klacht mede van invloed zullen zijn op de uitstelduur. Kenmerken als de ernst van de klacht en het karakter van de klacht, in de zin van overwegend somatisch of psychisch, zijn dan ook onderzocht voor wat betreft de samenhang met de uitstelduur. Er is alle reden om te veronderstellen, dat kenmerken van de arts 
en diens wijze van praktijkvoering eveneens samenhang vertonen met de uitstelduur. Dit onderzoek heeft zich in dit verband beperkt tot duidelijk waarneembare kenmerken van de arts en zijn praktijk, zoals het al of niet bestaan van een gestructureerd samenwerkingsverband, de spreekuurvorm, de praktijkgrootte en de leeftijd van de arts. In het tweede gedeelte van dit hoofdstuk worden diverse hypothesen nader beschreven.

In hoofdstuk II wordt de opzet en uitvoering van het onderzoek besproken, en wordt een beschrijving gegeven van de variabelen in relatie tot de hypothesen.

In totaal namen tweeëntwintig huisartsen aan het onderzoek deell. Deze zouden gedurende twintig dagen, vijf patiënten per dag ondervragen, dus per huisarts honderd patiënten. In totaal zouden dus 2200 patiënten worden ondervraagd. Als maand van onderzoek werd gekozen september, omdat in deze maand seizoensinvloeden minder frequent voorkomen dan anders.

Alleen patiënten die de huisarts voor een ,nieuwe klacht' raadpleegden werden ondervraagd. Onder een ,nieuwe klacht' werd verstaan een klacht, waarvoor de patiënt gedurende de voorafgaande twaalf maanden de huisarts niet had geraadpleegd.

Daarnaast werden door middel van interviews met de deelnemende huisartsen, gegevens over de arts en zijn praktijk vastgelegd.

Uit de literatuur (CASSEE 1973 en JESSEN 1974) bleek dat ten aanzien van kenmerken van de patiënt vooral de basisvariabelen: leeftijd, geslacht en opleiding, van invloed zijn op de uitstelduur. Ten aanzien van de klacht werd de uitstelduur steeds bij overeenkomstige klachten vergeleken. Om deze redenen werd de analyse apart uitgevoerd voor de basisvariabelen: leeftijd, geslacht en opleiding van de patiënt, en voor de aard van de klacht.

Ter beoordeling van de motivering om niet langer uit te stellen werd de patiënten gevraagd naar de reden van komst naar de arts. In totaal werden gegevens verzameld over zestien variabelen:

DE AFHANKELIJKE VARLABELE:

1. De uitstelduur.

DE ONAFHANKELIJKE VARIABELEN:

Patient: 2. Geslacht.

3. Leeftijd.

4. Opleiding. 
5. Frequentie huisartsenbezoek.

6. Stads- of plattelandspatient.

7. Ervaring met de klacht.

Klacht : 8. Aard van de klacht.

9. Indeling van de klacht naar orgaanstelsel.

10. Ernst van de klacht.

11. Karakter van de klacht wat betreft overwegend psychisch of somatisch.

12. Reden van consultatie.

Huisarts en praktijk: 13. Samenwerkingsverband.

14. Spreekuurvorm.

15. Praktijkgrootte.

16. Leeftijd huisarts.

In deze studie wordt onder de uitstelduur verstaan, de tijdsduur tussen het moment waarop men een gevoel van onwelzijn resp. een ziekteverschijnsel voor het eerst waarneemt, en het moment waarop daarvoor de hulp van de huisarts wordt ingeroepen.

In het resterende deel van dit hoofdstuk wordt, waar nodig, een beschrijving van iedere variabele gegeven, te zamen met een literatuurverwijzing, en wordt de relatie tot de hypothese(n) aangegeven.

In hoofdstuk III volgt een analyse van de onderzoekpopulatie in relatie tot de reeds vermelde zestien variabelen. Aan het onderzoek werd deelgenomen door vijftien huisartsen in solopraktijken en zeven huisartsen in associatiepraktijken resp. twaalf huisartsen in plattelandspraktijken en tien huisartsen in stadspraktijken. Zestien praktijken hadden een afspraakspreekuur en zes praktijken een vrij spreekuur. De huisartsen waren in de ene elf praktijken jonger dan veertig jaar, en in de andere elf praktijken veertig jaar of ouder.

Tijdens het consult werd de patiënt gevraagd, sinds hoe lang hij de klacht op dàt moment had. Ter verkrijging van de uitstelduur werd bij afspraakspreekuren van deze ,duur van de klacht' de tijdsduur, vanaf het maken van een afspraak tot het consult, in mindering gebracht. In de meeste gevallen ( $91 \%$ ) was de tijdsduur, tussen het moment van afspraak maken en het moment van consult, niet langer dan $1 \mathrm{dag}$. Teneinde tot een overzichtelijke en verantwoorde verdeling te komen werd voor de 
uitstelduur de indeling $0,1,2$ en 3 gebruikt, waarbij 0 een uitsteldurur is $\leqslant 1$ dag; 1 is een uitstelduur $\leqslant 1$ week maar $>1$ dag; 2 is een uitstelduur $\leqslant 3$ weken maar $>1$ week; en 3 is een uitstelduur $>3$ weken. Zesentwintig procent van de onderzoekpopulatie bleek langer dan 3 weken uit te stellen, alvorens zij voor hun ,nieuwe klacht' de huisarts raadpleegden.

De onderzoekpopulatie bestond voor $57 \%$ uit vrouwen en voor $43 \%$ uit mannen. Ten aanzien van de leeftijd van de patiënt bleek, dat de populatie voor bijna tweederde deel bestond uit jongere patiënten (17- 45 jr.) en voor eenderde deel uit oudere patiënten $(\geqslant 46 \mathrm{jr}$.). Wat het opleidingsniveau betreft bleek, dat bijna tweederde deel van de onderzochte patiënten een lagere opleiding (1.b.o. of lager) had gehad, en nog geen eentiende deel een hogere opleiding (h.b.o. of academisch).

De meest voorkomende klachten in de onderzoekpopulatie waren: pijn in de rug, hoesten, gewrichtspijn, hoofdpijn, keelpijn, spierpijn en huiduitslag (Zie tabel 3.4.1.1.).

Ten aanzien van de indeling van de klacht naar orgaanstelsel bleek dat één op de vijf ,nieuwe klachten' in de populatie betrekking had op het bewegingsapparaat, waarvoor relatief meer ouderen $(\geqslant 46 \mathrm{jr}$.) dan jongeren (17- $45 \mathrm{jr}$.) raadpleegden. Hartklachten bleken bij oudere patiënten $(\geqslant 46 \mathrm{jr}$.) vier maal zo veel voor te komen als bij jongere patiënten $(17-45 \mathrm{jr}$ ). Daarbij was tussen mannen en vrouwen geen verschil aantoonbaar.

In hoofdstuk IV wordt de toetsing van de afzonderlijke hypothesen weergegeven. Uit het onderzoek bleek ten aanzien van de eigenschappen van de patiënt:

- vrouwen stelden langer uit dan mannen;

- oudere patiënten $(\geqslant 46 \mathrm{jr}$.) stelden langer uit dan jongere patiënten $(17-45 \mathrm{jr}$.$) ;$

- patiënten met hogere opleidingen stelden langer uit dan patiënten met lagere opleidingen;

- tussen consultfrequenties en uitstelduur kon in het merendeel der onderzochte groepen geen verband worden vastgesteld;

- in plattelandspraktijken stelden patiënten langer uit dan in stadspraktijken;

- patiënten die meer ervaring hadden met de klacht, in die zin dat zij de klacht al eens eerder hadden gehad eventueel daarvoor waren behandeld, stelden bij minder en minst ernstige klachten langer uit dan patiënten die geen ervaring hadden met de klacht. 
Ten aanzien van de eigenschappen van de klacht bleek:

- bij klachten die algemeen bekend staan als mogelijke aanwijzingen voor een ernstige ziekte, stelden patiènten korter uit dan bij klachten die niet algemeen bekend staan als mogelijke aanwijzingen voor een ernstige ziekte;

- bij klachtenpatronen gepaard gaande mèt pijn stelden patiënten korter uit dan bij klachtenpatronen zònder pijn;

- bij klachten die als overwegend psychisch werden aangemerkt, stelden patiënten langer uit dan bij klachten die als overwegend somatisch werden aangemerkt.

Ten aanzien van eigenschappen van de huisarts en zijn praktijk bleek:

- wanneer huisartsen relatief meer klachten als psychisch aangaven, was de uitstelduur van patiënten in hun praktijken langer dan wanneer zij relatief meer klachten als somatisch aanmerkten;

- tussen patiënten in associatie- en solopraktijken was geen verschil in uitstelduur aantoonbaar;

- in praktijken met vrij spreekuur stelden patiënten langer uit dan in praktijken met afspraakspreekuur;

- tussen patiënten in grotere en kleinere praktijken was geen verschil in uitstelduur aantoonbaar;

- bij oudere huisartsen ( $\geqslant 40 \mathrm{jr}$.) stelden patiënten langer uit dan bij jongere huisartsen $(<40 \mathrm{jr}$. $)$.

De uitstelduur bleek relatief minder lang te zijn, indien:

a. De patiënt een man was, van jongere leeftijd was, een lagere opleiding had; ingeschreven was in een stadspraktijk.

b. De klacht algemeen bekend stond als mogelijke aanwijzing voor een ernstige ziekte; de klacht gepaard ging mèt pijn; de klacht een overwegend somatisch karakter had.

c. De huisarts relatief meer klachten als somatisch aanmerkte; de huisarts jonger was dan 40 jaar.

d. De praktijk een afspraakspreekuur had.

In hoofdstuk $V$ willen we tot synthese komen. Indien een aantal hypothesen afzonderlijk en in detail wordt getoetst, blijven enige belangrijke vragen onbeantwoord. Tussen de verschillende onafhankelijke variabelen, die in de hypothesen zijn vermeld als mogelijke determinanten van de uitstelduur, kunnen allerlei interacties en verbanden bestaan, die ertoe leiden dat sommige hypothesen ten onrechte worden bevestigd, en misschien andere ten onrechte niet aantoonbaar zijn. Een definitieve 
uitspraak over de houdbaarheid van een hypothese is dan ook alleen te doen als bij de toetsing, de invloed van alle andere in de overige hypothesen vermelde variabelen wordt uitgeschakeld.

Naast de noodzatak een in de samenvattende analyse eventueel doorkruisende factor constant te houden, doet zich nog een tweede probleem voor. Het is denkbaar dat een hypothese niet houdbaar is voor de onderzochte populatie als geheel, maar slechts voor een gedeelte daarvan. Om deze vragen rond de samenhang van de hypothesen en de op grond daarvan ontwikkelde variabelen te beantwoorden is gebruik van multivariate analyse noodzakelijk. Gekozen werd voor twee technieken.

- Multipele regressieanalyse schat de bijdrage van elke onafhankelijke variabele (leeftijd, geslacht enz.) in de verklaarde variantie van de afhankelijke variabele (uitstelduur), nadat voor alle andere variabelen gecontroleerd is.

- Contrastgroepenanalyse onderzoekt de gelijktijdige werking van een aantal onafhankelijke variabelen op een afhankelijke variabele. De contrastgroepenanalyse bestaat uit afzonderlijke stappen, waarbij bij iedere stap gezocht wordt naar dié dichotomie, welke het beste contrast geeft in de variantie van de afhankelijke variabele. Op deze wijze ontstaat een ,boomstructuur".

Speciaal geïnteresseerd waren we in de variabelen betreffende kenmerken van de huisarts en zijn praktijk. In de overige onafhankelijke variabelen werd, door middel van samenvoeging van sommige variabelen, getracht een reductie aan te brengen. Ten aanzien van de variabelen betreffende kenmerken van de patiënt bleek geen samenvoeging mogelijk te zijn. Ten aanzien van de variabelen betreffende kenmerken van de klacht was deze mogelijkheid wel aanwezig, waarbij de variabelen klachtenpatronen mèt of zònder pijn, ernst van de klacht en overwegend somatisch of psychisch karakter van de klacht, werden samen genomen tot één nieuwe variabele; de urgentiegraad van de klacht.

De multipele regressieanalyse liet zien dat de verklaarde variantie in de uitstelduur ten gevolge van de onderzochte onafhankelijke variabelen slechts $11 \%$ bedroeg. Het grootste deel van de variantie in de afhankelijke variabele kon dus niet verklaard worden door deze set van variabelen. Allerlei unieke aspecten van de patiënt, zijn klacht, zijn huisarts en diens praktijk speelden kennelijk een grotere rol. Toch bleek uil tabel 5.3.3. dat de meeste variabelen bij deze analyse significante uitkomsten gaven. Dit had echter niet veel betekenis gezien de lage waarden van de bèta's, waarbij slechts drie waarden eruit sprongen. 
Onweerlegbaar vertoonden samenhang met de uitstelduur:

- de urgentiegraad van de klacht, waarbij patiënten bij klachten met een hoge urgentiegraad gemiddeld korter uitstelden dan bij klachten met een lage urgentiegraad;

- het geslacht van de patiënt, waarbij mannen gemiddeld korter uitstelden dan vrouwen;

- de spreekuurvorm, waarbij patiënten in praktijken met afspraakspreekuur gemiddeld korter uitstelden dan in praktijken met vrij spreekuur.

Twee variabelen (patiëntenaantal en samenwerkingsverband) vertoonden géẻn samenhang met de uitstelduur van de patiënt.

De overige zeven variabelen gaven slechts een zeer geringe samenhang te zien.

De urgentiegraad had veruit het grootste effect op de uitstelduur. Daarom werd de samenhang bestudeerd tussen de onafhankelijke variabelen. en de afhankelijke variabele voor iedere urgentiegraad afzonderlijk. Allereerst bleek dat bij de hoogste urgentiegraden geen significante multipele correlaties optraden. Dit betekent dat bij de hoogste urgentiegraden van de klacht, bij de uitstelduur nauwelijks andere variabelen uit ons onderzoek een rol speelden dan de klacht zelf.

Ten aanzien van de overige onafhankelijke variabelen bleek dat:

- het geslacht van de patiënt voornamelijk bij lagere urgentiegraden samenhang vertoonden met de uitstelduur:

- de leeftijd van de patiënt de enige variabele was die bij een hogere urgentiegraad van de klacht tot een significant resultaat leidde. Jongere patiënten van $17-45$ jaar stelden gemiddeld korter uit dan oudere patiënten $\geqslant 46$ jaar;

- de variabelen spreekuurvorm, leeftijd huisarts en som./psych. arts samenhang vertoonden met de uitstelduur bij méér dan eén urgentiegraad van de klacht;

- de variabelen stad/platteland, patiënt-arts contacten, opleiding patiënt en ervaring met de klacht slechts bij én urgentiegraad van de klacht tot resultaten leidden.

Bij de contrastgroepenanalyse werden de eerste splitsingen teweeggebracht door de urgentiegraad van de klacht. Deze variabele bleek ook bij deze methode de grootste samenhang te hebben met de uitstelduur van de patiënt. Uit tabel 5.4.1. bleek dat dezelfde drie variabelen als bij de multipele regressieanalyse van belang waren: urgentiegraad klacht, 
geslacht patiënt en spreekuurvorm. Van minder belang waren de variabelen leeftijd huisarts en leeftijd patiënt voor de variantie in uitstelduur. De variabelen ervaring met klacht, opleiding patiënt en patiënt-arts contacten waren slechts van geringe betekenis voor de variantie in uitstelduur. De variabelen stad/platteland, som./psych. arts, patiëntenaantal en samenwerkingsverband waren niet van belang voor de uitstelduur van de patiënt. Op grond hiervan kon worden gesteld dat de relaties met urbanisatie en som./psych. arts bij de regressieanalyse waarschijnlijk het gevolg waren van de problematiek van de hoge correllaties.

De resultaten van de multipele regressieanalyse en de contrastgroepenanalyse bleken in grote lijnen met elkaar in overeenstemming te zijn. In tabel 5.5.1. zagen we dat de drie variabelen: geslacht patiënt, leeftijd patiënt en spreekuurvorm, zowel bij de multipele regressieanalyse als de contrastgroepenanalyse, bij twee overeenkomstige urgentiegraden van de klacht samenhang vertoonden met de uitstelduur van de patiënt. De variabelen leeftijd huisarts, patiënt-arts contacten en ervaring met de klacht vertoonden deze samenhang, bij beide analyses, slechts bij één overeenkomstige urgentiegraad van de klacht. We merken op dat bij de variabele leeftijd huisarts bij de contrastgroepenanalyse een factor van enig gewicht behouden bleef. Gegeven de uitkomsten van de multipele regressieanalyse en de contrastgroepenanalyse kunnen we stellen dat:

- de urgentiegraad van de klacht een duidelijk verband vertoonde met de uitstelduur van de patiënt;

- de structurele variabelen geslacht en leeftijd van de patiënt eveneens samenhang vertoonden met de uitstelduur;

- ten aanzien van kenmerken van de huisarts en zijn praktijk, de variabelen spreekuurvorm en, in geringe mate, leeftijd huisarts samenhang vertoonden met de uitstelduur van de patiënt. Patiënten stelden bij jongere huisartsen $(<40 \mathrm{jr}$.) relatief korter uit dan bij oudere huisartsen $(\geqslant 40 \mathrm{jr}$.).

In hoofdstuk VI wordt een nadere analyse uitgevoerd van de patiënten die langer dan drie weken uitstelden. Onze speciale belangstelling ging uit naar de patiënten, die bij klachten met een hoge urgentiegraad langer dan drie weken uitstelden. Vooral deze patiënten geven ons reden tot bezorgdheid. De onderzoekpopulatie werd ingedeeld in:

a. Patiënten die bij klachten met de hoge urgentiegraad 7 langer dan drie weken uitstelden.

b. Alle overige onderzochte patiënten. 
Van beide populaties werd aan de hand van kenmerken van de patiënt en kenmerken van de huisarts en zijn praktijk de samenstelling bepaald. Hierbij bleek dat oudere patiënten $(\geqslant 46 \mathrm{jr}$.) relatief meer bij klachten met een hoge urgentiegraad (7) langer dan drie weken uitstelden dan jongere patiënten $(17-45 \mathrm{jr}$.). Ten aanzien van de overige onderzochte variabelen was geen verschil tussen beide populaties aantoonbaar. Dit bevestigt datgene wat in hoofdstuk $\mathrm{V}$ over urgentiegraad is aangetoond. Ten aanzien van de klacht stelden van de zestig patiënten die hun huisarts consulteerden wegens een knobbeltje, vijftien patiënten (25\%) langer dan drie weken uit. Dit percentage is hoog te noemen. Van de vierenvijftig patiënten met de klacht pijn bij plassen, stelden zeven patiënten $(13 \%)$ langer dan drie weken uit alvorens de arts te raadplegen. Van de eenenveertig patiënten die hun huisarts consulteerden wegens de klacht pijn op de borst, stelden drie patiënten $(7 \%)$ langer dan drie weken uit. Waarom stelden deze patiënten zo lang uit? Als reden van consulatie van de huisarts noemden patiënten, die bij klachten met een hoge urgentiegraad langer dan drie weken uitstelden, relatief vaak dat zij gestuurd werden door anderen of dat zij de huisarts consulteerden voor een andere klacht. Relatief minder vaak werden door deze patiënten de redenen ongerustheid of hinder genoemd.

In het tweede deel van dit hoofdstuk volgt een bespreking van de resultaten van dit onderzoek.

Welke implicaties hebben de gevonden resultaten voor de dagelijkse praktijk

Ouderen stellen in vergelijking met jongeren, en vrouwen in vergelijking met mannen langer uit. Omdat speciaal oudere patiënten ook geneigd zijn langer uit te stellen bij klachten met een hoge urgentiegraad, doet de huisarts er goed aan vooral bij oudere patiënten alert te zijn op ongewenst lang uitstel.

De resultaten van dit onderzoek vormen een aanwijzing dat patiënten in praktijken met afspraakspreekuur overwegend korter uitstellen dan in praktijken met vrij spreekuur. Dit zou een extra argument kunnen zijn voor het houden van afspraakspreekuren. Speciaal huisartsen met grote praktijken, die vrij spreekuur hebben, dienen alert te zijn op ongewenst lang uitstel van hun patiënten. 


\section{Summary}

As a general practitioner one notices that rather too frequently patients do not come at the appropriate moment to consult their doctor. On the one hand there are still patients with, say, a nodule in the breast, or coughing up blood, or with anal loss of blood, who wait too long before consulting their doctor. On the other hand there are patients who consult their doctor unnecessarily or prematurely, considering the nature of their complaints. If any improvements are to be made in this field one should first attempt to trace the causes of this inadequate delay. Should the cause depend mainly on the patient, through fear for instance, then proper information and guidance could do much to better the situation. It is equally possible, however, that for an important part the cause depends on the general practitioner and his way of conducting his practice. Is a certain way of conducting a practice to be preferred, considered against the background of this undue delay? Could, say, collaborative practices and consulting-hours by appointment affect patient's delay and if so, to what extent? Before introducing changes in the way of conducting a practice, research into these matters seems called for.

The above considerations gave rise to an examination of the question whether, and if so, to what extent, there is a demonstrable coherence between patient's delay on the one hand, and on the other hand the characteristics of the patient and of the complaints and of the family doctor, inclusive of his practice.

Apart from a description of the problem set Chapter I comprises the formulation of the hypotheses. On the model of CASSEE 1973, three structural variables were chosen with regard to characteristic features of the patient, viz. age, sex and level of formal education. Apart from this the frequency of visits to the doctor, place of residence and possible experience of the patient with the complaint were incorporated into the survey.

It seems evident that characteristics of the complaint will alsi affect patient's delay. Features like the seriousness of the complaint and the 
nature of the complaint, in the sense of their being predominantly somatic or psychic, have therefore been examined with regard to their possible relation with patient's delay. There is every reason to assume that characteristics of the physician and his way of conducting his practice will equally show a correlation with patient's delay. Given this context the present survey restricts itself to clearly apparent features of the physician and his practice, such as the existence or absence of a structured collaborative relation, the way in which consulting-hours are organized, the size of the practice and the physician's age. In the latter half of this chapter several hypotheses are more closely described.

In Chapter II the framework of the research and its elaboration are discussed. Moreover a description is given of the variables with regard to the hypotheses. A total of twenty-two general practitioners participated in the enquiry. They were to interview five patients a day during a period of twenty days, a total of one hundred patients for each physician. Consequently a total of 2,200 patients were to be interviewed. September was selected as most appropriate for the investigation, since seasonal influences occur less frequently in this month than in others. Only patients consulting their doctors about a 'new complaint' were interviewed. A 'new complaint' was defined as one about which the patient had not consulted his doctor during the preceding twelve months.

In addition to this data regarding the physician and his practice were recorded by means of interviews with the general practitioners participating in the enquiry.

From the literature on the subject (CASSEE 1973 and Jessen 1974) it appeared that, as far as the characteristics of the patient are concerned, it is primarily the basic variables of age, sex and education that affect patient's delay. With regard to the complaint the periods of postponement were compared whenever there was similarity of complaints. For these reasons the analysis was made separately for the basic variables patient's age, sex and education, and for the nature of the complaint.

In order to assess the motives for delaying no longer, the patients were asked to state their reasons for consulting the doctor.

Data were collected on a total of sixteen variables:

THE DEPENDENT VARIABLE:

1. Patient's delay. 


\author{
Patient: 2. Sex. \\ 3. Age. \\ 4. Education. \\ 5. Frequency of wisits to the doctor. \\ 6. Urban or rural place of residence. \\ 7. Experience with the complaint \\ given. \\ Complaint: 8. Nature of the complaint. \\ 9. Classification of complaint accord- \\ ing to system of organs. \\ 10. Seriousness of the complaint. \\ 11. Characteristics of the complaint \\ predominantly psychic or somatic. \\ 12. Reason for consulting the doctor. \\ G.P. and practice: 13. Collaborative relation. \\ 14. Organization of consulting-hours. \\ 15. Size of practice. \\ 16. Physician's age.
}

In this study the term 'Patient's delay' must be understood to mean the period of time inbetween the moment at which a feeling of being unwell, or a symptom of illness is noticed for the first time, and the moment at which for this reason a physician is consulted.

In the remainder of this chapter a description is given, wherever necessary, of each variable, together with bibliographical references. Moreover the relation to the hypothesis or hypotheses is indicated.

Chapter III gives an analysis of the research population with regard to the above sixteen variables. Participating in the survey were fifteen physicians in solo practices and seven in associated practices. Twelve of these were rural and ten were urban practices. Sixteen practices had consulting-hours bij appointment, whereas six had open consulting-hours. In eleven practices the physicians were younger than forty years of age, whereas in the remaining eleven the physicians' ages were forty and over. During the consultation the patient was asked how long he or she had had the complaint at that moment. In order to arrive at the correct figure for patient's delay in the case of consulting-hours by appointment, the period of time from the moment the appointment was made until the 
actual consultation was subtracted from this 'duration of the complaint'. In most cases (91\%) the period of time between the moment of making the appointment and the moment of consultation did not exceed one day. In order to arrive at a convenient and proper arrangement the classifications $0,1,2$ and 3 were used to indicate patient's delay. In this system 0 stands for a patient's delay $\leqslant 1$ day; 1 indicates a period $\leqslant 1$ week but $>1$ day; 2 is a delay $\leqslant 3$ weeks but $>1$ week and 3 means a postponement $>3$ weeks. Twenty-six per cent of the research population proved to postpone longer than three weeks before consulting their doctor about a "new complaint". Fifty-seven per cent of the research population were women and forty-three per cent were men. As regards patients' ages almost two-thirds of the population turned out to consist of younger patients of seventeen to forty-five years old, the remaining one-third being older patients of forty-six and over.

With reference to level of education nearly two-thirds of the patients interviewed proved to have had a so-called lower education (technical school or lower) and less than ten per cent had had a higher education (higher vocational training or university).

The most frequent complaints among the research population were: pain in the back, coughing, joint-pain, headache, sore throat, muscular pain and cutaneous eruption (Cp. table 3.4.1.1.).

With reference to the classification of the complaint according to system of organs, it appeared that one in five 'new complaints" in the research population related to the kinetic apparatus, about which, relatively speaking, more older people ( $\geqslant 46 \mathrm{yrs}$.) consulted their doctor than younger people (17-45 yrs.). Heart-complaints proved to be four times as frequent with older patients $(\geqslant 46 \mathrm{yrs}$.) as with younger patients $(17-45$ yrs.) without any demonstrable difference between men and women.

Chapter IV comprises the testing of each hypothesis individually. The investigation showed, with reference to the characteristics of the patient:

- women postponed longer than men;

- older patients $(\geqslant 46 \mathrm{yrs}$.) made longer delays than younger patients $(17-45 \mathrm{yrs})$;

- patients with a high level of education postponed longer than patients with a lower level of education;

- among the majority of the groups under consideration no connection could be established between frequency of consultation and patient's delay; 
- in rural practices patient's delay proved to be longer than in urban practices;

- patients who were more familiar with the complaint, in the sense that they had previously suffered from the given complaint and had possibly undergone medical treatment because of that complaint, tended to postpone for a longer period of time in the case of less and least serious complaints than patients who had no experience with the complaint.

With reference to the characteristics of the complaint, it appeared that:

- in case of complaints that are generally known as possibly indicative of a serious disease, patients tended to postpone for a shorter period of time than in the case of complaints that are not generally known as such;

- in case of complaint patterns accompanied by pain patients postponed for shorter periods of time than in case of complaint patterns without pain;

- in case of complaints that were considered as predominantly psychic, patients postponed for a longer time than with complaints that were considered as predominantly somatic.

With reference to the physician and his practice, it appeared that:

- when general practitioners diagnosed relatively more complaints as psychic, patient's delay in their practices was longer than when physicians regarded relatively more complaints as somatic;

- there were no demonstrable differences in patient's delay between patients in solo practices and associated practices;

- in practices with open consulting-hours patient's delay was longer than in practices with consulting-hours by appointment;

- there was no evidence of difference in patient's delay between patients from larger and smaller practices;

- with older physicians ( $\geqslant 40$ yrs.) patients postponed for longer periods of time than with younger physicians $(<40 \mathrm{yrs}$.).

Patient's delay proved to be relatively shorter, if:

a. The patient was a man of 17-45 years old, with a lower level of formal education, belonging to an urban practice. 
b. The complaint was generally known as possibly indicative of a serious illness; the complaint was accompanied by pain; the nature of the complaint was predominantly somatic.

c. The general practitioner diagnosed relatively more complaints as somatic; the physician was younger than forty years of age.

d. The practice had consulting-hours by appointment.

Chapter V aims at a synthesis. If a number of hypotheses is tested separately and in detail, some important questions remain unanswered. Among the various independent variables mentioned in the hypotheses as possible determiners of patient's delay, there may be all kinds of interactions and relations contributing to undue confirmation of some hypotheses, whereas others may unduly fail to gain justification. A final judgement of the tenability of a hypothesis is only possible if, in testing, the influence of all the other variables mentioned in the remaining hypotheses is eliminated.

Apart from the need to keep a possible interfering factor constant in the comprehensive analysis, there is yet another problem. It is conceivable that a hypothesis is not tenable for the test population as a whole, but only for part of it. In order to answer these questions concerning the coherence of the hypotheses and the variables based on them, the use of multivariate analysis is imperative. Two techniques were selected:

- Multiple Regression Analysis assesses the contribution of each independent variable (age, sex, etc.) in the explained variance of the dependent variable (patient's delay), after a check has been made for all other variables.

- Automatic Interaction Detection (AID) examines the simultaneous influence of a number of independent variables on a dependent variable. AID consists of separate steps, at each of which that dichotomy is looked for which yields the best contrast in the variance of the dependent variable. In this way a so-called three structure is arrived at.

We were especially interested in the variables concerning characteristics of the physician and his practice. An attempt was made to arrive at a reduction in the remaining independent variables by means of joining certain variables. As regards the variables concerning the characteristics of the patient, junction appeared to be impossible. As regards the variables concerning the nature of the complaint, junction appeared to be feasible. 
Thus the variables complaint patterns accompanied or unaccompanied by pain, seriousness of the complaint and nature of the complaint being either predominantly somatic or psychic, were joined into one new variable: degree of urgency of the complaint.

Multiple Regression Analysis showed that the explained variance in patient's delay as a result of the independent variables as examined did not amount to more than eleven per cent. Therefore the major part of the variance in the dependent variable could not be explained by this set of variables. Several unique aspects of the patient, his complaint, his physician and the latter's practice obviously played a more important part. Yet from table 5.3.3. it appeared that most variables in this analysis yielded significant results. However, this was not of major importance because of the low values of the betas, among which only three values were clearly projecting.

Indisputable correlation with patient's delay was shown by:

- the degree of urgency of the complaint. Thus patients with complaints that are of a high degree of urgency showed a shorter average of delay than those with complaints of a low degree of urgency;

- the patient's sex. Men showed a shorter average of delay than women;

- the organization of consulting-hours. Patients in practices with consulting-hours by appointment showed a shorter average of delay than those in practices with open consulting-hours.

Two variables, viz. number of patients and associated practices, showed no correlation with patient's dellay.

The remaining seven variables did not show more than a minute correlation.

The degree of urgency had by far the greatest effect on patient's delay. Therefore the correlation was studied between the independent variables and the dependent variable for each separate degree of urgency. First of all it appeared that with the highest degrees of urgency there were no significant multiple correlations.

This implies that, with the highest degrees of urgency of the complaint, hardly any variables of the present survey affected patient's delay apart from the complaint itself.

With regard to the remaining independent variables it appeared that:

- the patient's sex correlated with patient's delay, mainly at lower degrees of urgency; 
- the patient's age was the only variable leading to a significant result, given a higher degree of urgency of the complaint. Younger patients from 17 to 45 years of age showed a shorter average delay than older patients of 46 years and over;

- the variables organization of consulting-hours, physician's age and the physician being either predominantly somatically or psychically inclined proved to correlate with patient's delay at more than one degree of urgency of the complaint;

- the variables urban versus rural practice, contacts patient - physician, patient's level of education and experience with the complaint yielded results in merely one degree of urgency of the complaint.

In the Automatic Interaction Detection procedure the first divisions were caused by the degree of urgency of the complaint. In this method also this variable proved to show maximum correlation with patient's delay. From table 5.4.1. it appeared that the same three variables as in the Multiple Regression Analysis were essential, viz. degree of urgency of the complaint, patient's sex and organization of consulting-hours. The variables physician's age and patient's age were less important for the variance in patient's delay. The variables experience with the complaint, patient's level of education and contacts patient - physician were of minor importance for the variance in patient's delay. The variables urban versus rural practice, the physician being either predominantly somatically or psychically inclined, number of patients and associated practices were of no importance for patient's delay. On account of this it might be posited that in the regression analysis the relations with urbanization and the physician being either predominantly somatically or psychically inclined, were probably the result of the issue of the high correlations.

The results of both Multiple Regression Analysis and Automatic Interaction Detection appeared to be largely in agreement. In table 5.5.1. we saw that the three variables patient's sex, patient's age and organization of consulting-hours, in both the Multiple Regression Analysis and AID, correlated with patient's delay in two corresponding degrees of urgency of the complaint. The variables physician's age, contacts patient physician and experience with the complaint showed this correlation in only one corresponding degree of urgency of the complaint in both analyses.

We notice that in the variable physician's age one factor of some impor- 
tance was retained in AID. Given the results of both Multiple Regression Analysis and AID it may be posited that:

- the degree of urgency of the complaint clearly correlated with patient's delay;

- the structural variables patient's sex and age also correlated with patient's delay;

- with regard to the characteristics of the physician and his practice, the variables organization of consulting-hours and, to a lesser degree, physician's age correlated with patient's delay. With younger physicians ( $<40$ yrs.) patient's delay was relatively shorter than with older physicians $(\geqslant 40$ yrs. $)$.

In chapter VI a closer analysis is made of patients who postponed longer than three weeks. We were particularly interested in those patients who postponed longer than three weeks, even with complaints of a high degree of urgency.

It is especially these patients who cause reason for anxiety. The population of this study was subdivided into:

a. Patients with complaints of the high degree of urgency 7 postponing longer than three weeks.

b. All remaining patients examined.

The composition of both populations was determined based on characteristics of the patient and characteristics of the physician and his practice. It appeared that a relatively larger number of older patients $(\geqslant 46 \mathrm{yrs}$.) with complaints of a high degree of urgency (7) tended to postpone longer than three weeks, compared to younger patients (17-45 yrs.). With regard to the remaining variables that were studied, there was no demonstrable difference between the two populations. "Th"s confirms what was demonstrated about degree of urgency in chapter $\mathrm{V}$.

As regards the complaint, fifteen out of sixty patients, i.e. $25 \%$, consulting their GP about a nodule postponed longer than three weeks. This may be called a high percentage. Out of a total of fifty-four patients with the complaint "pain when urinating", seven patients $(13 \%)$ postponed longer than three weeks before consulting their GP. Out of a total of forty-one patients consulting their doctor because of the complaint "pain in the chest", three patients $(7 \%)$ postponed longer than three weeks. Why did these patients postpone for such a long period of time? Patients with complaints of a high degree of urgency postponing longer 
than three weeks relatively often mentioned as a reason for consulting their GP that they had been advised to do so by others, or that they were consulting their family doctor because of some other complaint. Relatively less frequently these patients mentioned anxiety or inconvenience as reasons for consulting their GP.

In the latter part of this chapter the results of this analysis are discussed.

Which are the implications of the results obtained for everyday use?

Compared to younger people older people postpone longer; and again: women postpone longer than men. Since particularly older patients also tend to postpone longer in case of complaints with a high degree of urgency, the general practitioner would do well to be on the alert for undesirable long delays, especially with older patients.

The results of the present study are an indication that patients in a practice with consulting-hours by appointment on the whole postpone shorter than those in practices with open consulting-hours. This could imply an argument in support of consulting-hours by appointment. Especially physicians with large practices and open consulting-hours should be on the alert for undesirable long delays on the part of their patients. 


\section{Literatuur}

AAzsTER, C. W. (1974). Beschouwingen over aard en ontstaan van gezondheidsstoornissen. Nederlands Tijdschrift voor Geneeskunde, 118, (6), 199.

Absinatiry, V. (1973). Social Network and Respons to the Maternal Role. International Journal of Sociology of the Family, $3,86$.

Armaks-SWan, I. and R. Paterson (1955). The Cancer Patient; Delay in Seeking Advice. Britisch Medical Journal, $12,623$.

Aldous, J. and M. A. Strauss (1965). Social Networks and Conjugal Roles; a Test of Bott's Hypothesis. Social Forces, 43, 576.

Alpert, J. J, J. Kosa and R. J. HAGoerty (1967). Medical Help and Maternal Nursing Care in Life of Low Income Families. Pediatrics, 39, 749.

Ambersfen, R. (1968). A Behavioral Model of Familie's Use of Health Services. Chicago, Center for Health Adm. Studies (Research Series 25), 32 en 75.

Andersen, R., O. W. ANDerson and B. Smediy (1968). Perception of and Response to Symptoms of Illness in Sweden and the United States. Medical Care, 6,18 .

ANDERson, O. W. (1963). "The Utilization of Health Services. In: Freeman, H. E, S. Levine and L. G. Reeder (eds.). Handbook of Medical Sociology. Prentice Hall, New York, Englewood Cliffs, 349.

Anderson, R. and J. D. Kasper (1972). The Structural Influence of Family Size on Children's Use of Physician Services. Journal of Comparative Family Studies, $6,(1), 116$.

Aulbers, B. J. M. en F. DE WAARD (1970). Praktijkanalytische gegevens uit het intermitterend morbiditeitsonderzoek. Huisarts en Wetenschap, 13, 171.

Balunt, $M_{n}$ (1957). The Doctor, his Patient, and the Illness. New York, Int. Univ. Press.

BATrtstella, R. M. (1968). Limitations in Use of the Concept of Psychological Readiness to Initiate Health Care. Medical Care, 6, 308.

Becker, M. H., ea. (1974). A Now Approach to Explaining Sick-role Behawior in Low Income Populations. American Journal of Publick. Fealth, 14, 205.

Bergama, J. J. (1966). Preventief geneeskundïg onderzoek in de huisartspraktijk; een onderzoek met behulp wan een schriftelijke anamnese, proefschrift Nijmegen, Dekker en Van de Vegt.

Blackwell, B. (1963). The Literature of Delay in Seeking Medical Care for Chronic Illness. Health Education Monographs, 16, 3.

BLACKWELL, B. J. (1967). Upper Middle Class Adult Expectation about Entering the Sickrole for Physic and Psychiatric Dysfunctions. Joumal of Health and Social Behavior, 8,2 . 
BLood, R. O. (1969). Kinship Interaction and Marital Solidarity, Merril Palmer Quarterly, 171.

Bloom, S. W. (1963). The Doctor and his Patient. New York, Russell Sage Foundation.

Bolssevar, J. F. (1968). Netwerken en quasigroepen; inaugurale rede Amsterdam. Assen, Van Gorcum en Comp.

Booth, A. and N. BABchux (1972). Seeking Health Care from New Resources. Journal of Health and Social Behavior, 13, 90.

BotT, E. (1968). Family and Social Network. London.

Bouma, J. en Tj. TrmstRa (1977).Verwachting en waardering wan een groepspraktijk. Huisarts en Wetenschap, 20, 131.

Bramhage, C. A. A. (1962). Gezondheid en ziekte te Zutphen; enquête naar de gezondheidszorg bij 536 gezinnen. Assen, Van Gorcum.

BREMER, G, J. (1969). De diagnostische functie van de huisarts; inleiding tor de huisartsgeneeskunde. Leiden, Stenfert Kroese, 43.

BRENKMAN, A. F. (1963). De huisarts en het gezin van zijn patient, proefschrift Utrecht. Assen, Van Gorcum.

BRouwER, W. (1969). Gesprekstherapie; inleiding tot de huisartsgeneeskunde. Leiden, Stenfert Kroese.

BRouwer, W. (1969). De huisarts-patiënt-relatie; inleiding tot de huisartsgeneeskunde. Leiden, Stenfert Kroese.

Brouwer, W. en F. Touw-OTTEN (1974). Van klacht tot klagen; een analyse van de pré-medische fase. Huisarts en Wetenschap, 17, 3.

BurR, W. R. (1971). An Expension and Test of a Role Theory of Marital Satisfaction. Journal of Marriage and the Family, 368.

BUYTENDIJK, F. J. J. (1957). Over de pijn. Utrecht, Het Spectrum.

Cartwright, A. (1967). Patients and their Doctors; a Study of General Practice. London, Routledge and Kegan Paul.

CasseE, E. TH. (1970). Onbevoegde genezers en hun patiënten; afwijkend gedrag in de gezondheidszorg. Sociologische Gids, 5, 393.

Cassee, E. Th. (1973). Naar de dokter. Meppel, Boom.

CATE, R. S. TEN (1956). De praktijkhulp van de buisarts. Leiden, Stenfert Kroese.

CATE, R. S. TEN (1958). Afspraakspreekuur voor de huisarts. Huisarts en Welenschap, 1, 186.

CATE, R. S. TEN (1973). De praktijkvoering van de huisarts in solo- en groepspraktijk. Leiden, Stenfert Kroese.

Cons, B. (1954). Patient Possible Delay in the Treatment of Cancer. Cancer, 7, 920.

CRERolder, H. (1977). Onderzoekingen rond het gezondheidscentrum Withuis; opvattingen van de cliënt over zijn huisarts. Huisarts en Wetenschap, 20, 178.

Crebolder, H. (1977). Onderzoekingen rond het gezondheidscentrum Withuis; enige aspecten van de organisatie en werkwijze van het gezondheidscentrum beoordeeld door de cliënten. Huisarts en Wetenschap, 20, 301.

DAvrs, M. S. (1968). Physiologic, Psychological and Demographic Factors in Patient Compliance with Drctor's Orders. Medical Care, 6, 115. 
Drkxes, J. M. (1967). Arbeid en stress; het vaststeilen van aanpassingsproblemen in werksituaties (Nederlands Instituut voor Praeventieve Geneeskunde TNO). Groningen, Wolters.

DIJK, P. VAN (1976). Geneeswijzen in Nederland; compendium yoor de niet-universitaire geneeskunde Deventer, Ankh. Hermes.

Dool, C. W. A. WAN DEN (1960). Enige mogelijkheden tot het vroegtijdig opsporen van chronische ziekten door de huisarts. Leiden, Stenfert Kroese.

DOoL, C. W. A. WAN DEN (1970). Opsporing van chronische ziekten in de huisartspraktijk: mogelijkheden tot secundaire preventie. Huisarts en Welenschap, $13,3$.

DookN, J. A. A. VAN (1956). Het medisch ventiel voor maatschappelijk falen. Sociologische Gids, 3, 152.

Doorn-Janssen, M. J. Wan (1971-1972). Projekt Gezin en Familie, Utrecht, Sociol. Inst. R. U. Utrecht, $2 \mathrm{dnl}$. (Mededelingen van het Sociol. Inst. te Utrecht no. $81 \mathrm{~A}+\mathrm{B})$.

Dunnell, K. and A. Cakrwarout (1972). Medicine Takers, Prescribers and Hoarders. London.

EDmonds, V. H. (1972). Adjustment, Conservatism and Marital Conventionalization. Journal of Marriage and the Family, 96.

ElJk, J. TH. M. vaN, e.a. (1978). De weekenddienst wan huisartsen in Nederland. Medisch Contact, 33, 17, 37 en 73.

EIJK, J. TH. M. VAN (1979). Verschillen in praktijkvorering van huisartsen. Medisch Contact, $31,987$.

EIIK, J. TH. M. VAN (1979). Levensgebeurtenissen en ziekte. Nijmegen, Dekker en Van de Vegt.

Elluot-Binns, C. P. (1973). An Analysis of Lay Medicine. Joumal of the Royal College of General Practitioners, 23, 255.

Es, J. C. VAN (1969). De patiënt; inleiding tot de huisartsgeneeskunde. Leiden, Stenfert Kroese, 1.

Es, J. C. vaN (1969). Het morbiditeitspatroon in de huisartspraktijk; inleiding tot de huisartsgeneeskunde. Leiden, Stenfert Kroese; 13.

Es, J. C. VAN (1969). De huisarts; inleiding rot de huisartsgeneeskunde. Leiden, Stenfert Kroese, 34.

Es, J. C. VAN (1969). Gezinsgeneeskunde; inleiding tot de huisarisgeneeskwnde. Leiden, Stenfert Kroese, 162.

Es, J. C. vaN (1969). De structuur van de huisartspraktijk; inleiding tot de huisartsgeneeskunde. Leiden, Stenfert Kroese, 277.

Es, J. C. VAN (1974). Pattient en huisarts; een leerboek huisartsgeneeskunde. Utrecht, Oosthoek, Scheltema en Holkema.

Ferkutre, A. J. and W. D. WinTER (1974). On the Nature of Marital Relationships; Measurable Differences in Spontaneous Agreement. Family Process, 13, 355.

Folmer, H. R. (1968). Huisarts en ijsberg; proefschrift Utrecht. Zaltbommel, Avanti.

Forsyth, G. and R. F. L. Logan (1964). Medical Technology and Needs of Chronic Disease. Journal of Chronic Diseases, 17, 789. 
HEYOWNDABL, P. H. J. M., e.a. (1972). Gezin en ziekte. Nijmegen, Dekker en Van de Vegt.

HrL, R. (1958). Social Stresses on the Family. Social Casework, 139.

Hut, R, ea. (1970). Family Development in Three Generations. Masschetusetts.

"Hoe helpi de dokter?" Speciale uitgave Nederlands Huisartsen Genootschap, juli 1975 .

Holruurs, F. e,a (1973). Psychosomatiek; het groen-boek. Meppel, Boom.

HutTer, F. J. en K ReEnoers (1977). Huisartsenberaad. Huisarts en Wetenschap, $20,154$.

HuYGeN, $F_{.,}$e.r. (1977). Een praktijk doorgelicht op CARA, I, II en III. Huisarts en Wetenschap, $20,383,435$ en 438.

Huysmans, F, exa. (1973), Gezondheidszorg in Nederland. Nijmegen, Sun.

IEMHor ${ } \mathbf{F}$. (1979). Klacht en interpretatie in geneeskunde en gezondheidszorg. Een kritiek van het medisch werklarings- en behandelingsmodel. Nijmegen, Link.

ILLicil, J. (1974). Het medisch bedrijf een bedreiging voor de gezondheid? Baarn, Het Wereldvenster.

JaCkson, Don D. (1966). Family Practice; a Comprehensive Medical Approach. Comprehensive Psychiatry, 7, 338.

JACOBS, H. M., Touw-OTteN, F. en De Melker, R. (1979). Taakopvatting en ziekenhuisbezoek. Huisarts en Wevenschap, 22, 226.

JEsSEN, I. L. (1974). Medische Consumptie; onderzoek naar medische consumptie van de Nederlanders anno 1970. Groningen, Rijksuniversiteit.

JoNGE, $H_{.}$DE (1963). Inleiding tot de medische statistiek. I. 2e druk. Groningen, Wolters-Noordhoff; (1964) idem. II. 2e druk. Groningen, Wolters-Noordhoff.

Joosten, J. en H. Philipsen (1978). De medische ernst van klachten en diagnosen; verslag van een beperkt onderzoek naar de mogelijkheid deskundigen te gebrujken als beoordelaars van de sterkte van de samenhang tussen klachten en lichamelijke aandoeningen. Maastricht, Rijksuniwersiteit.

Kagan, A. R. and I. Levi (1974). Health and Enwironment - Psychosocial Stimuli a Review. Social Science and Medicin, 8, 225.

KaLIMo, E. (1969). Determinants of Medical Care Utilization. Helsinkil.

Kasl, S. V. and S. Cons (1966). Health Behavior, Hllness Behavior and Sick-role Behavior. Archieves of Environmentel Health, 12, 246 en 531 .

Kaupen-HAas (1969). Stabilität und Wandel ärtzlicher Autorität. Stuttgart, Ferdinand Enke Verlag.

Kellnek, R. (1963). Family III Health. Tavistock Publications.

Kerknoff, A. C. (1972). Status-Related Value Patterns among Married Couples. Jounnal of Marriage and the Family, 105.

Kessez, N. and M. SHeprerd (1965). The Health and Attitudes of People who Seldom Consult a Doctor. Medical Care, 3, 6.

Kinlay, J. B. Mc. (1972). Some Approaches and Problems in the Study of the Use of Services, an Overview. Journal of Health and Social Behavior, 13, 115.

Krascm, J. P. (1974). The Health-Belief-Model and Illness Behavior. Health Education Monographs, 2. 
Fremson; E. (1960). Client Control and Medical Practice American Jommal of Sociology, 65,374 .

Fremson, E. (1961). Patient's Views of Medical Practice. New York, Russell Sage Foundation.

Freidson, E. (1972). Profession of Medicine; a Study of the Sociology of Applied Knowledge. New York.

Frrerdon, E. (1975). Dillemma's in the Doctor-Patient Relationship. In: Cox, C. and A. Mead (ed.). A Sociology of Medical Practice. London, 285.

Frenken, J. (1975). Sexualiteitsbeleving en huwelipksrelatie. Zeist, Nisso.

Fuldauter, A. (1966). Bejaardenonderzoek in een huisartspraktijk. Hengelo, Insulinde.

GADOUREK, I. (1963). Riskante gewoonten en zorg voor eigen welzijn. Groningen, Wolters.

Gadourek, I. and J. L. Jessen (1970). Use and Abuse of Medical Drugs; a Research. Paradigm. Groningen; Wolters.

GeERTSEN, R. e.a. (1975). A Reëxamination of Suchman's View on Social Factors in Health Care Utilization. Journal of Health and Social Behavior, 16, 226.

Gersmar, L. L. (1974). A Framework for Cross National Research on the Effects of Family Policy. Journal of Comparative Family Studies, 8, 109.

Gogmman, D.S. (1972). The Organizing Role of Motivation in Health Beliefs and Intentions. Journal of Health and Social Behavior, 13, 285.

Goldsen, R. K. (1963). Patient Delay in Seeking Cancer Diagnosis; Behavioral Aspects. Journal of Chronic Diseases, 16, 427.

Grolnick, L. (1972). A Family Perspective of Psychosomatic Factors in Illness; a Review of the Literature. Family Process, 11, 457.

Groog, S. H., A. Lipson and S. Levine (1972). Help Patterns in Severe Illness; the Roles of Kin-Network, Non-Family Resources and Institutions. Journal of Marriage and the Family, 32.

HACKetT, T. P., e.a. (1973). Patient Delay in Cancer. New England Journal of Medicin, 5, 14.

HADLEY, TR. R., e.a. (1974). The Relationship between Family Developmental Crises and the Appearance of Symptoms in a Family Member. Framily Process, $13,207$.

Hafs, W. F. M. DE, J. H. Schuurman en F. Sturmans (1976). Gezondheidswoorlichting en opvoeding, I, II en III. Medisch Contact, 31, 385, 421 en 457.

Haggerty, R. J. (1968). Family Crises; the Role of the Family in Health and IIIness. Ambulatory Pediatrics, (ed. by Haggerty $\mathbb{R}$. J. and M. Green), 774.

Hare, E. H. and G. K. SHaw (1965). A. Study in Family Health (1), Health in Relation to Family Size. Britisch Journal of Psychiary, 111, 461; (2), a Comparison of the Health of Fathers, Mothers and Children. Britisch Journal of Psychiatry, 111, 467.

Hartmamin, H. (1964). Funktionale Autorität. Stuttgart, Ferdinand Enke Verlag.

Hermans, E. H., e.a. (1972). De arts als patiënt. Leiden, Stafleu.

Hetherington, R. W. and C. E. HopkINs (1969). Symptom Sensitiwity, its Social and Cultural Correlates. Health Services Research, Spring, 63. 
KLINEERT, J. J. (1974). Macht wan artsen, een bezorgde verkenning van een profersie. Assen, Van Gorcum.

KLINkERT, J. J. (1978). Huisarts en professie, I, II en IIT. Huisarts en Wetenschep, $21,6,43$ en 93 .

Kooy, G. A. (1969). Het huwelijk in Nederland. Utrecht, Het Spectrum.

Kooy, G. A. (1975). Sexualiteit, huwelijk en gezin in Nederland. Deventer, Van Loghum Slaternus.

Koos, E. L. (1967). The Health of Regionville. New York en London.

Kort na elkaar overlijden van echtgenoten (vraag en antwoord). (1971). Nederlands Tijdschrift vaor Geneeskunde, $115,(9), 374$.

Kosa, J., J. J. ALPERT and M. N. Pickering (1965). Crisis and Stress in Fanily Life; a Re-Examination of Consepts. The Wiscoumsin Sociologist, $4,11$.

KosA, J. and L. S. ROBERTSON (1969). Social Aspects of Health and Illness. In: Kosa, J., A. Antonovsky and I. Zola. Poverty and Health; a Sociological Analysis. Cambridge, Mass., Havard Univ. Press, 35.

Kutner, B. and G. Gordan (1961). Seeking Care for Cancer. Journal of Health and Human Behavior, 2, 171.

Kuyvenhoven, M. en F. Touw-Orren (1976). Projekt ,pré-medische fase'; verslag van het literatuuronderzoek naar de oorzaken van verschillen in medischconsumptief gedrag in het bijzonder het raddplegen van de huisarts in relatie met het functioneren van het gezin. Utrecht, Rijksuniversiteit.

LADEE, G. A. (1978). De verzekerings en de ,pijnpatiënt'. Tijdschrift voor Sociale Geneeskunde, 56, 207.

LAMBERTS, H. (1974 en 1975). De morbiditeitsanalyse door de groepspraktijk Ommoord; een nieuwe ordening van ziekte- en probleemgedrag voor huisartsengeneeskunde, I en II. Huisarts en Wetenschap, 17, 455 en 18, 7 .

LAsr, J. M. (1963). The Iceberg Completing the Clinical Picture in General Practice. Lancet, 7297.

LEFrToN, M, e.a. (1966). Former Mental Patients and their Neighbours; a Comparison of Performance Levels. Journal of Health and Human Behavior, 7, 106.

LEwIS, L. S. and J. LopREA To (1962). Arationality, Ignorance and Perceived Danger in Medical Practices. American Sociological Review, 27, 508.

LIDTH DE JEUDE, A. H. VAN (1971). De huisarts in de malstroom der emoties. Leiden, Stenfert Kroese.

Lrtman, Th. J. (1974). The Family as the Basic Unit in Health and Medical Care; a Sociobehavioral Overview. Social Science and Medicin, 8, 495.

LoGAN, W. P. D. and E. M. Brooke (1957). The Survey of Sickness, 1943 to 1952. London, H. M. Stationery Office. (Studies on Medical and Population Subjects 12).

LOGAN, W. P. D. and A. A. CUSHION (1958). Morbidity Statistics from General Practice; Vol. I en II. London.

Magdalarne, M., H. Pequinot et $G$. Rosch (1965). Un modèle mathematique de la consommation des soins medicaux. Presse Medicine 1973, 1319.

MAman, L. A. and M. A. BECKER (1974). The Health Belief Model; Origins and Correlates in Psychological Theory. Health Education Monographs, 2, (4), 336. 
Mangus, A. R. (1957). Role Theory and Marriage Counseling. Social Forces, 35, 200.

Mechawre; D. and E H. Volkart (1960). Illness Behavior and Medical Diagnosis. Joumal of Health and Human Behaviar, 1, 86.

Mechandic, D. and E. H. VolKakt (1961). Stress, Illness Behavior, and the Sickrole. American Sociological Review, $26,51$.

Mechanrc, D. (1968). Medical Sociology, a Selective View. New York.

Merz, W. (1975), Pijn, en teer punt. Nijkerk, Callenbach.

Msчвоом, W. A. (1979). Praktijkverkleining en werkbelasting. Huisarts en Wetensehap, 22, 441.

Meyer, R J and R. J. Haggerty (1969). Streptococal Infections in Families; Factors Altering Individual Susceptibility. Pediatrics, 29, geciteerd bij Van Es, op cit: $189,442$.

Mrluer, F. J. W., e.a. (1960). Growing up in New Castle upon Tyne London.

MrLler, M. H. (1973). Seeking Advice for Cancer Symptoms. American Journal of Public Health, 13, 955.

Moorz, M. (1978). Ziekenfondslidmaatschap en het raadplegen van de huisarts. Medisch Contact, 33, 1465.

"Morbiditeit' gezondheidscentrum Hoensbroek-Noord. (1970). VOMIL.

Morredl, D. C. (1965). The Art of General Practice. London.

Nederlands Huisartsen Instituut - enquête inzake registratie gegevens samenwerkingsverbanden. (1977). Huisarts en Wetenschap, $20,250$.

NIPHUIS-NELL, M. (1974). De gezinsfasen. Amsterdam, SISWO-interimrapporten, censusmonografieën.

Ninior, G. (1967). Collectief ontslag en psychische volksgezondheid. Maandblad voor de Geestelijke Volksgezondheid, $22,140$.

Oliemans, A. P. (1969). Morbiditeit in de huisartsenpraktijk. Leiden, Stenfert Kroese.

Ollemans, A. P. en W. vaN DE Ven (1975). Morbiditeitsanalyse in een solohuisartspraktijk. Huisarts en Wetenschap, 18, 437.

Orsen, H. (1970). The Impact of Serious Illness on the Family System. Medicin, $47,169$.

Omgeving van de woning; sociale contacten en priwacy in oudere stadswijken, literatuuronderzoek. Centrale directie van do volkshuisvesting en de bouwnijverheid, afdeling stedebouwkundig onderzoek, 1969, XIII.

Omgeving van de woning; sociale kontakten en privacy in oudere stadswijken. Centrale directie van de volkshuisvesting en de bouwnijverheid, afdeling stedebouwkundig onderzoek, $1971, \times, 53$.

ORMEL, H. (1975). Het psychofarmacagebruik anno 1970. Tijdschrift voor Sociale Geneeskunde, 53,494 .

PArsons, T. (1951). Iliness and the Role of the Physician; a Sociological Perspective. American Journal of Orthopsychiatry, $21,452$.

Parsons, T. (1952). The Social System. New York, The Free Press, 436.

Parsons, T. (1970). The Social System. New York, The Free Press, 428. 
Persoow, J. G. M. (1975). Veranderingen in de huisarts-patiënt relatie. Assen, Van Gorcum.

Petron, F. A. (1969). Social Class, Family Size and the Role. Joumal of Marriage and the Family, 31,728 .

PFLANZ, M. (1969). Gesundheitsverhalten. In: Mitscherlich, A., T. Brocher, O. Von Mering et al. Der Kranke in der modernen Gesellschaft. Köln etc., Kiepenheuer etc., 283.

PHILIPSEN, H. (1969). Afwezighe״d wegens ziekte. Groningen, Wolters.

PHullrps, D. L. (1965). Self-reliance and the Inclination to Adapt the Sick-role. Sacial Forces, $43,555$.

Plaats, taak en functie wan de huisarts. LHV-informatie bulletin, uitgave van het Centraal Bestuur der Landelijke Huisartsen Vereniging, nr. 2, juni 1979.

Plokg, H. VAN DER (1976 en 1977). Onderzoek naar het verband tussen frequentie van huisartsbezoek en persoonlijkheidskenmerken. I en II. Huisorts en Wetenschap, 19,451 en 20,22 .

Postma, T. en H. Schouwengurg (1976). Achtergrondproblemen van spreekuurbezoekers. Huisarts en Wetenschap, 19, 132.

PRATT, L. (1972). Conjugal Organization and Health. Journal of Marriage and the Family, 34, 85.

Prupe, L. F. (1968). An Adrenal Stress Index as a Criterion Measure for Nursing. Nursing Research, 17, 292.

Raphael, E. E. (1964). Community Structure and Acceptance of Psychiatric Aid. American Journal of Sociology, 69, 340.

RAuPp, J. L. M. (1971). Over werkwijzen van huisartsen; een kwantitatief onderzoek naar verschillen in de werkwijzen van solowerkende huisartsen in Limburg. Proefschrift Nijmegen. Helmond, Van Stiphout.

Renne, K.S. (1971). Health and Marital Experience in an Arban Population. Journal of Marriage and the Family, 33, 338.

Rrchardson, H. B. (1948). Patients have Families. New York.

RIJPMA, S. (1973). Gezondheid en gezinsindividualisering in een agrarische gemeenschap. Lochem, De Tijdstroom, 111.

Robertson, L. S., e.a. (1967). Family Size and the Use of Medical Resources. In: Liu, W.T., Family and Fertility, South. Ben. Indiana, University of Notre Dame Press, 131.

Rodakrs, R. H. (1964). Toward Theory of Family Development, Journal of Marriage and the Family, 26, 262.

RoDGers, R. H. (1973). Family Interaction and Transaction - the Developmental Approach. Prentice Hall.

Rogmman, K. J. and R. J. HagcerTy (1972). The Diary as a Research Instrument in the Study of Health and Illness Behavior. Medical Care, 10, (2), 143.

Roghman, K. J., P. K. Hecht and R. J. Haggenty (1973). Family Coping with Every Day Illness; Self-reports from a Household Survey. Journal of Comparative Family Siudies, 7, 49.

Rosenblatt, D. and E. A. Suchmann (1965). Blue-Collar Attitudes and Information toward Health and Illness. In: Shostak, A. B. and W. Gomberg (eds.), BlueCollar World; Studies on the American Worker; 2 nd. printing. Prentice Hall, Englewood Cliffs, 324. 
Rosenstock, 1. (1966). Why People use Health Services. Milbank Memorial Fund Quarterly, 44, 94.

RurGH, A. DE (1973). Milieufactoren en gezondheidsbeleving. Nijmegen, Dekker en Van de Vegt.

RƯMKe, CHR. L., H. DE JONGE en R. VAN STRIK (1975). Het statistisch toetsen van hypothesen. Nederlands Tijdschrift voor Geneeskunde, 119, 2038.

RÜMKE, CHR. L. (1976). De nauwkeurigheid wan percentages; tabellen met betrouwbaarheidsintervallen. Nederlands Tijdschrift voor Geneeskunde, 120, 2052.

RÜmKE, CHR. L. en C. DE WrTH (1977). De grootte van de groepen bij het vergelijken van twee percentages of twee kansen. Nederlands Tijdschrift voor Geneeskunde, $121,944$.

Scrimale, A. H. (1958). Relationship of Seperation and Depression to Disease. Psychosomatic Medicin, 20, 259.

Schmale, A. H. (1972). Psysical lllmess and Family Dynamics. Adv. Psychosontatic Medicin, 8, 237.

Schmror, H. G. en A. J. WaN Loon (1977). Opnieuw de arts-patiënt relatie. Medisch Contact, 32, 27.4.

Shuval, J. T. (1970). Social Functions of Medical Practice; Doctor-Patient Relationship in Israël. San Francisco.

Shuval, J. T, e.a. (1973). Illness, a Mechanism for Coping with Failure. Social Science and Medicin, 7, 259.

SrGekrst, H. E. (1962). Civilization and Disease. Chicago-London.

SKIPPER, J. K. and R. C. LeONARD (1968). Children, Stress and Hospitalization; a Field Experiment. Journal of Health and Human Behavior, 9, 257.

SorrT, C. M. (1971). Dyadic Interactions in a Doublebind Situation. Family Processus, 10,53 .

Solloway, J. C. and P. B. Dillon (1973). A Comparison of Family Networks and Friend Networks in Health Care Utilization. Journal of Comparative Family Studies, $7,131$.

StoecklE, I. D. and G. E. Davmson (1963). Communicating Aggrieved Feelings in the Patient's Initial Visit to a Medical Clinic. Joumal of Health and Human Behavior, 4, 199.

Stoeckle, J. D., J. K. Zola and G. E. Davidson (1963). On going to see the Doetor, the Contibutions of the Patient to the Decision to seek Medical Aid. Jourmal of Chronic Diseases, 16, 975 .

Srobckux, J. D., J. K. ZOLA and G. E. DAvioson (1964). The Quantity and Significance of Psychological Distress in Medical Patients. Journal of Chronic Diseases, $17,959$.

Suchman, E. A. (1964). Sociomedical Variations among Ethnic Groups. American Journal of Sociology, 70, 319.

Suchman, E. A. (1965). Social Patterns of Illness and Medical Care. Journal of Health and Human Behavior, 6, (a), 2.

Suchman, E. A. (1965). Stages of Illness and Medical Care. Journal of Health and Human Behavior, 6, (b), 114.

Suchman, E. A. (1966). Health Orientation and Medical Care. American Journal of Public Health, 6, 97. 
Sussman, M. B. (1965). Relationship of Adult Children with their Parents. In: Shanas, E. and G. Streib (eds.). Social Structure and the Family; Generational Relations. New York, Englewood Cliffs, 62.

Swangond, P. G. (1974). Aspecten wan het sociologisch onderzoek. Meppel, Boom.

Toomey, D. M. (1971). Conjugal Roles and Social Networks in an Urban Working Class Sample. Human Relations, 24, 417.

TWADDLE, A. C. (1974). The Concept of Health Status. Social Science and Medicin, $8,29$.

Veen, W. A. VAN (1977). Compliance. In: Hypertensie. Huisarts en Praktijk. Nederlands Huisartsen Genootschap, juni, 26.

VELDEN, A. G. M. VAN DE (1971). Huisarts, huisvrouw, huisgezin. Nijmegen.

Vercruissse, E. V. W. (1974). Huisarts en sociaal wetenschappelijk onderzoek. Nederlands Huisartsen Instituut.

WaDswoth, M. E. J., e.a. (1971). Health and Sickness; the Choice of Treatment. London.

WAN, TH. J. and SC. J. SolfFER (1974). Deterninants of Physician Utilization. Journal of Health and Social Behavior, 15, 100.

WazLAwick, P. (1966). A Structured Family Interview. Family Process" 2, 256.

WeIsz, J. E. and M. R. GRIENLICK (1970). Determinants of Medical Care Utilizations; the Effect of Sociall Class and Distance on Contacts with the Medical Care System. Medical Care, 8, 456.

WEYEL, J. (1961). Medische psychologie; psychologie en psycho-therapie van de huisarts. Utrecht, Erven I. Bijleveld.

WILDE, G. J. S. DE (1963). Neurotische labiliteit gemeten volgens de vragenlijstmethode. Amsterdam, F. van Rossem.

Wulliams, W. O. (1973). Present State and Future Needs of General Practice. 3 ed. Bijlage bij Joumal of the Royal College of General Practitioners.

Wrucmott, P. and M. Young (1960). Family and Class; in a London Suburb. London.

Winkler Prins, J. (1966). Huisarts en patiënt; een empirisch-sociologisch onderzoek naar het verband tussen maatschappelijke bindingen van patiënten en hun beeld over de huisarts. Meppel, Boom.

IJzekmans, $\mathrm{C}_{\text {. }}$ en $\mathrm{H}$. Schouwendurg (1976). Huisartsen en hun probleempatienten: kwaliteit van de arts-patiënt communicatie. Huisarts en Wetenschap, 19, 185.

ZiBonowskx, M. (1958) Cultural Components in Response to Pain. In: Jaco, E. G. (ed.). Patients, Physichans and Illness. New York.

Znorowsky, M. (1969). People in Pain, Jossy Bass Inc. Publishers.

ZoLA, I. K. (1962). Socio-Cultural Factors in the Seeking of Medical Aid. New York.

ZolA, I. K. (1963). Problems of Communication, Diagnosis and Patient Care. Journal of Medical Education, 38, 829.

ZoLA. T. K. (1966). Culture and Symptoms; an Analysis of Patients' Presenting Complaints. American Sociological Review, 31, 615.

ZoLA, I. K. (1973). Pathways to the Doctor; from Person to Patient. Social Science and Medicin, 7, 677 . 
Bijlagen 


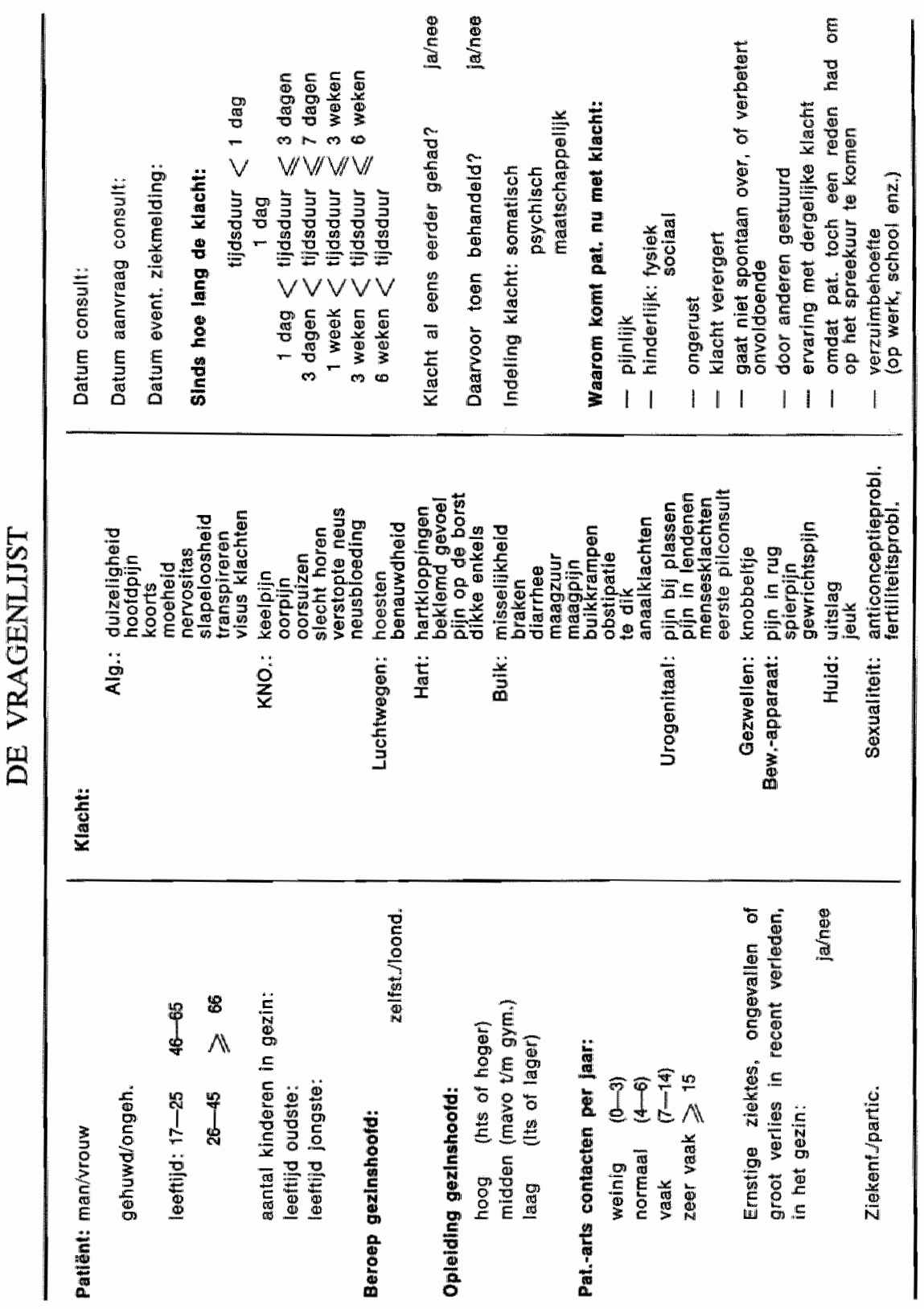


Tabel 3.3.3.2. Verband tussen opleidingsniveau en leeftijd van patienten in de populatie.

\begin{tabular}{lccc}
\hline & $\begin{array}{c}17-45 \text { jaar } \\
\%\end{array}$ & $\begin{array}{c}\text { 46 jaar } \\
\%\end{array}$ & $\begin{array}{c}\text { Total } \\
\%\end{array}$ \\
Opleiding & 60 & 69 & 63 \\
Laag & 31 & 22 & 28 \\
Midden & 9 & 9 & 9 \\
Hoog & $100(\mathrm{~N}=1341)$ & $100(\mathrm{~N}=689)$ & $100(\mathrm{~N}=2030)$ \\
Totaal & $\mathrm{P}<0,001$ & & \\
\hline Kendall's Tau $\mathrm{C}=-0,07$ & &
\end{tabular}

Tabel 3.3.3.3. Verband tussen geslacht en leeftijd van patiënten met een ,hogere opleiding' in de populatie.

\begin{tabular}{lccc} 
& $\begin{array}{c}17-45 \text { jaar } \\
\%\end{array}$ & $\begin{array}{c}\text { 46 jaar } \\
\%\end{array}$ & $\begin{array}{c}\text { Totaal } \\
\%\end{array}$ \\
\hline Vrouw & 60 & 35 & 52 \\
Man & 40 & 65 & 48 \\
\hline Totaal & $100(\mathrm{~N}=116)$ & $100(\mathrm{~N}=60)$ & $100(\mathrm{~N}=176)$ \\
\hline Chi-kwadraat $=9,18$ & $\mathrm{P}<0,01$ &
\end{tabular}

Tabel 3.3.3.4. Verband tussen opleidingsniveau en leeftijd van vrouwen in de populatie.

\begin{tabular}{lccc}
\hline Opleiding & $\begin{array}{c}17-45 \text { jaar } \\
\%\end{array}$ & $\begin{array}{c}\text { 46 jaar } \\
\%\end{array}$ & $\begin{array}{c}\text { Totaal } \\
\%\end{array}$ \\
\hline Laag & 58 & 72 & 63 \\
Midden & 33 & 22 & 29 \\
Hoog & 9 & 6 & 8 \\
\hline Totaal & $100(\mathrm{~N}=771)$ & $100(\mathrm{~N}=372)$ & $100(\mathrm{~N}=1143)$ \\
\hline
\end{tabular}

Kendall's Tau $C=-0,13 \quad P<0,001$ 
Tabel 3.3.3.5. Verband tussen opleidingsniveau en geslacht van jongere patienten in de populatie.

\begin{tabular}{lccc}
\hline Opleiding & $\begin{array}{c}\text { Vrouw } \\
\%\end{array}$ & $\begin{array}{c}\text { Man } \\
\%\end{array}$ & $\begin{array}{c}\text { Totalal } \\
\%\end{array}$ \\
\hline Laag & 58 & 62 & 60 \\
Midden & 33 & 30 & 32 \\
Hoog & 9 & 8 & 9 \\
\hline Total & $100(\mathrm{~N}=771)$ & $100(\mathrm{~N}=557)$ & $100(\mathrm{~N}=1328)$ \\
\hline
\end{tabular}

Kendall's Tau $C=-0,04 \quad P<0,1$

Tabel 3.3.3.6. Verband tussen opleidingsniveau en geslacht van oudere patienten in de populatie.

\begin{tabular}{lccc}
\hline Opleiding & Vrouw & Man & $\begin{array}{c}\text { Total } \\
\%\end{array}$ \\
\hline Laag & $\%$ & $\%$ & 68 \\
Midden & 72 & 64 & 23 \\
Hoog & 22 & 24 & 9 \\
\hline Totaal & 6 & 13 & $100(\mathrm{~N}=677)$ \\
\hline
\end{tabular}

Kendall's Tau $\mathrm{C}=0,1 \quad \mathrm{P}<0,01$

Tabel 3.3.4.2. Verband tussen consultrequentie en leeftijd van patienten in de populatie.

\begin{tabular}{lccc}
\hline & $17-45$ jaar & $\begin{array}{c}\text { 46 jaar } \\
\%\end{array}$ & $\begin{array}{c}\text { Totaal } \\
\%\end{array}$ \\
Consultfrequenties & $\%$ & 28 & 34 \\
Weinig & 37 & 44 & 44 \\
Normal & 44 & 28 & 22 \\
Vaak & 19 & $100(\mathrm{~N}=691)$ & $100(\mathrm{~N}=2039)$ \\
\hline Totaal & $100(\mathrm{~N}=1348)$ & 1000 \\
\hline
\end{tabular}

Kendall's Tau $\mathrm{C}=0,12 \quad \mathrm{P}<0,001$ 
Tabel 3.3.4.3. Verband tussen consultfrequentie en leeftijd van mannen in de populatie.

\begin{tabular}{lccc}
\hline Consultfrequenties & $\begin{array}{c}17-45 \text { jaar } \\
\%\end{array}$ & $\begin{array}{c}46 \text { jaar } \\
\%\end{array}$ & $\begin{array}{c}\text { Totaal } \\
\%\end{array}$ \\
Weinig & 46 & 36 & 43 \\
Normaal & 37 & 43 & 39 \\
Vaak & 17 & 21 & 18 \\
Totaal & $100(\mathrm{~N}=559)$ & $100(\mathrm{~N}=306)$ & $100(\mathrm{~N}=865)$ \\
\hline
\end{tabular}

Kendall's Tau $C=0,10 \quad P<0,01$

Tabel 3.3.4.4. Verband tussen consultfrequentie en leeftijd van vrouwen in de populatie.

\begin{tabular}{lccc}
\hline Consultfrequenties & $\begin{array}{c}17-45 \text { jaar } \\
\%\end{array}$ & $\begin{array}{c}46 \text { jaar } \\
\%\end{array}$ & $\begin{array}{c}\text { Totaal } \\
\%\end{array}$ \\
\hline Weinig & 30 & 21 & 27 \\
Normaal & 50 & 45 & 48 \\
Vaak & 20 & 34 & 25 \\
\hline Totaal & $100(\mathbb{N}=776)$ & $100(\mathbb{N}=373)$ & $100(\mathbb{N}=1149)$ \\
\hline
\end{tabular}

Kendall's Tau $C=0,15 \quad P<0,001$

Tabel 3.3.4.5. Verband tussen consultfrequentie en opleiding van patiënten in de populatie.

\begin{tabular}{lcccc}
\hline $\begin{array}{l}\text { Opleiding } \\
\text { Consultfrequenties }\end{array}$ & $\begin{array}{c}\text { Laag } \\
\%\end{array}$ & $\begin{array}{c}\text { Midden } \\
\%\end{array}$ & $\begin{array}{c}\text { Hoog } \\
\%\end{array}$ & $\begin{array}{c}\text { Totaal } \\
\%\end{array}$ \\
\hline Weinig & 31 & 38 & 40 & 34 \\
Normaal & 43 & 48 & 45 & 44 \\
Vark & 26 & 15 & 15 & 22 \\
\hline Totaal & 100 & 100 & 100 & 100 \\
& $(\mathrm{~N}=1287)$ & $(\mathrm{N}=579)$ & $(\mathrm{N}=1.83)$ & $(\mathrm{N}=2049)$ \\
\hline
\end{tabular}

Kendall's Tau $B=-0,11 \quad \mathrm{P}<0,001$ 
Tabel 3.3.5.2. Verband tussen ,stads-plattelandspatient" en leeftijd van de patiénten in de populatie.

\begin{tabular}{lccc}
\hline & $\begin{array}{c}17-45 \text { jaar } \\
\%\end{array}$ & $\begin{array}{c}46 \text { jaar } \\
\%\end{array}$ & $\begin{array}{c}\text { Totaal } \\
\%\end{array}$ \\
\hline Plattellandspatiënt & 57 & 50 & 55 \\
Stadspatiënt & 43 & 50 & 46 \\
\hline Totaal & $100(\mathrm{~N}=1352)$ & $100(\mathrm{~N}=693)$ & $100(\mathrm{~N}=2045)$ \\
\hline
\end{tabular}

Chi-kwadraat $=7,07 \quad \mathbf{P}<0,01$

'Tabel 3.3.6.2. Verband tussen, ervarüng met de klacht' en leeftijd van patiënten in de populatie.

\begin{tabular}{lccc}
\hline & $\begin{array}{c}17-45 \text { jaar } \\
\%\end{array}$ & $\begin{array}{c}46 \text { jaar } \\
\%\end{array}$ & $\begin{array}{c}\text { Total } \\
\%\end{array}$ \\
\hline Geen ervaring & 52 & 41 & 48 \\
Wel ervaring & 48 & 59 & 52 \\
\hline Totaal & $100(\mathrm{~N}=1352)$ & $100(\mathrm{~N}=693)$ & $100(\mathrm{~N}=2045)$ \\
\hline
\end{tabular}

Chi-kwadraat $=22,06 \quad$ P $<0,001$

Tabel 3.3.6.3. Verband tussen, ervaring met de klacht" en leeftijd van vrouwen in de populatie.

\begin{tabular}{lccc}
\hline & $\begin{array}{c}17-45 \text { jaar } \\
\%\end{array}$ & $\begin{array}{c}46 \text { jaar } \\
\%\end{array}$ & $\begin{array}{c}\text { Totaal } \\
\%\end{array}$ \\
\hline Geen ervaring & 54 & 38 & 49 \\
Wel ervaring & 47 & 62 & 52 \\
\hline Totaal & $100(\mathrm{~N}=766)$ & $100(\mathrm{~N}=368)$ & $100(\mathrm{~N}=1134)$ \\
\hline Chi-kwadraat $=23,24$ & $\mathrm{P}<0,001$ & &
\end{tabular}


Tabel 3.3.6.4. Verband tussen, ervaring met de klacht' en opleiding van patiënten in die popullatie.

\begin{tabular}{lcccc}
\hline Opleiding & $\begin{array}{c}\text { Laag } \\
\%\end{array}$ & $\begin{array}{c}\text { Midden } \\
\%\end{array}$ & $\begin{array}{c}\text { Hoog } \\
\%\end{array}$ & $\begin{array}{c}\text { Totaal } \\
\%\end{array}$ \\
\hline $\begin{array}{l}\text { Geen ervaring } \\
\text { Wel ervaring }\end{array}$ & 47 & 51 & 53 & 48 \\
\hline Totaal & 53 & 49 & 48 & 52 \\
& 100 & 100 & 100 & 100 \\
\hline
\end{tabular}

Kendall's Tau $C=-0,05 \quad P<0,1$

Tabel 3.4.2.2. Verband tussen klachtengroepen en leeftijd van patiënten in de populatie.

\begin{tabular}{lccc}
\hline & $\begin{array}{c}17-45 \text { jaar } \\
\text { Klachtengroepen }\end{array}$ & $\begin{array}{c}\text { 46 jaar } \\
\%\end{array}$ & $\begin{array}{c}\text { Total } \\
\%\end{array}$ \\
\hline Algemene klachten & 20 & 22 & 20 \\
K.n.o.- of luchtwegklachten & 20 & 20 & 20 \\
Hartklachten & 3 & 12 & 6 \\
Buikklachten & 12 & 9 & 11 \\
Urogenitaalklachten & 7 & 7 & 7 \\
Bewegingsapparaatklacht & 19 & 23 & 20 \\
Gezwellen of huidklachten & 12 & 7 & 10 \\
Sexualiteitsproblemen & 7 & 1 & 5 \\
Totanl & $100(\mathrm{~N}=1350)$ & $100(\mathrm{~N}=691)$ & $100(\mathrm{~N}=2041)$ \\
\hline Chi-kwadrat $=113,51$ & $\mathrm{P}<0,001$ & &
\end{tabular}


Tabel 3.4.2.3. Verband tussen klachtengroepen en geslacht van patienten in de populatie.

\begin{tabular}{lccc}
\hline Klachtengroepen & $\begin{array}{c}\text { Vrouw } \\
\%\end{array}$ & $\begin{array}{c}\text { Man } \\
\%\end{array}$ & $\begin{array}{c}\text { Totall } \\
\%\end{array}$ \\
\hline Algemene klachten & 22 & 19 & 21 \\
K.n.o.- of luchtwegklachten & 16 & 25 & 20 \\
Hartklachten & 6 & 6 & 6 \\
Buikklachten & 11 & 10 & 11 \\
Urogenitaalklachten & 11 & 2 & 7 \\
Bewegingsapparaatklacht & 15 & 27 & 20 \\
Gezwellen of huidklachten & 11 & 10 & 11 \\
Sexualiteitsproblemen & 8 & 1 & 5 \\
\hline Totaal & $100(\mathrm{~N}=1166)$ & $100(\mathrm{~N}=873)$ & $100(\mathrm{~N}=2039)$ \\
\hline
\end{tabular}

Chi-kwadrat $=178,32 \quad \mathrm{P}<0,001$

Tabel 3.4.2.4. Verband tussen klachtengroepen en leeftijd van mannen in de populatie.

\begin{tabular}{|c|c|c|c|}
\hline Klachtengroepen & $\frac{45 \text { jaar }}{\%}$ & $\begin{array}{c}\geqslant 46 \text { jaar } \\
\%\end{array}$ & $\begin{array}{c}\text { Totaal } \\
\text { \% }\end{array}$ \\
\hline Algemene klachten & 18 & 19 & 18 \\
\hline K.n.o.- of luchtwegklachten & 24 & 27 & 25 \\
\hline Hartklachten & 3 & 11 & 6 \\
\hline Buikklachten & 12 & 7 & 10 \\
\hline Urogenitaalklachten & 2 & 4 & 2 \\
\hline Bewegingsapparaatklacht & 29 & 24 & 27 \\
\hline Giezwellen of huidklachten & 12 & 8 & 11 \\
\hline Sexualiteitsproblemen & 1 & 1 & 1. \\
\hline Totaal & $100(\mathrm{~N}=560)$ & $100(\mathrm{~N}=304)$ & $100(\mathrm{~N}=864)$ \\
\hline
\end{tabular}

Chi-kwadraat $=33,40 \quad \mathbf{P}<0,001$ 
Tabel 3.4.2.5. Verband tussen klachtengroepen en leeftijd van vrouwen in de populatie.

\begin{tabular}{lccc}
\hline Klachtengroepen & $\begin{array}{c}17-45 \text { jaar } \\
\%\end{array}$ & $\begin{array}{c}46 \text { jaar } \\
\%\end{array}$ & $\begin{array}{c}\text { Totaal } \\
\%\end{array}$ \\
\hline Algemene klachten & 21 & 25 & 22 \\
K.n.o.- of luchtwegklachten & 17 & 15 & 16 \\
Hlartklachten & 3 & 13 & 6 \\
Buikklachten & 12 & 11 & 11 \\
Urogenitaalkilachten & 12 & 9 & 11 \\
Beweglingsapparaatklacht & 12 & 21 & 15 \\
Gezwellen of huidklachten & 13 & 6 & 10 \\
Sexualiteitsproblemen & 12 & 1 & 8 \\
\hline Total & $100(\mathrm{~N}=777)$ & $100(\mathrm{~N}=375)$ & $100(\mathrm{~N}=1152)$ \\
\hline Chi-kwadraat $=97,61$ & $\mathrm{P}<0,001$ & &
\end{tabular}

"Tabel 3.4.3.2. Verband tussen, ernst van de klacht" en leeftijd van patiënten in de populatie.

\begin{tabular}{lccc}
\hline Ernst van de klacht & $\begin{array}{c}17-45 \text { jaar } \\
\%\end{array}$ & $\begin{array}{c}46 \text { jaar } \\
\%\end{array}$ & $\begin{array}{c}\text { Totaal } \\
\%\end{array}$ \\
\hline 11 meest erristige & 22 & 31 & 25 \\
18 minder ernstige & 49 & 46 & 48 \\
11 minst ernstige & 29 & 24 & 27 \\
\hline Totaal & $100(\mathrm{~N}=1173)$ & $1.00(\mathrm{~N}=627)$ & $100(\mathrm{~N}=1800)$ \\
\hline Kendall's Tau $\mathrm{C}=-0,09$ & $\mathbf{P}<0,001$ & &
\end{tabular}

Tabel 3.4.3.3. Verband tussen, ernst van de klacht' en geslacht van patiènten in de populatie.

\begin{tabular}{lccc}
\hline Ernst van de klacht & $\begin{array}{c}\text { Vrouw } \\
\%\end{array}$ & $\begin{array}{c}\text { Man } \\
\%\end{array}$ & $\begin{array}{c}\text { Totaal } \\
\%\end{array}$ \\
\hline 11 meest ernstige & 22 & 28 & 25 \\
18 minder ernstige & 47 & 50 & 48 \\
11 minst ernstige & 31 & 22 & 27 \\
\hline Totaal & $\mathbb{1 0 0}(\mathrm{N}=1025)$ & $100(\mathrm{~N}=775)$ & $100(\mathrm{~N}=1800)$ \\
\hline
\end{tabular}

Kendall's Tau $\mathrm{C}=-0,11 \quad \mathrm{P}^{\prime}<0,001$ 
Tabel 3.4.3.4. Verband tussen, 11 meest ernstige ktachten' en leeftijd van patiènten in de populatie.

\begin{tabular}{lccc}
\hline & $17-45$ jaar & $\begin{array}{c}46 \text { jaar } \\
\%\end{array}$ & $\begin{array}{c}\text { Totaal } \\
\%\end{array}$ \\
11 meest ernstige klachten & $\%$ & 4 & 8 \\
Oorpijn & 10 & 8 & 6 \\
Slecht horen & 5 & 11 & 9 \\
Benauwdheid & 7 & 14 & 10 \\
Pijn op do borst & 7 & 6 & 3 \\
Dikke enkels & 1 & 4 & 5 \\
Braken & 6 & 1 & 2 \\
Maagzuur & 2 & 1 & 3 \\
Anaalklachten & 4 & 13 & 12 \\
Pijn bij plassen & 12 & 9 & 14 \\
Knobbeltje & 17 & 30 & 29 \\
Gewrichtspijin & 29 & $100(\mathrm{~N}=192)$ & $100(\mathrm{~N}=451)$ \\
\hline Totaal & $100(\mathrm{~N}=259)$ & & \\
\hline
\end{tabular}

Chi-kwadraat $=34,07 \quad P<0,001$

Tabel 3.4.3.5. Verband tussen, 11 minst ernstige klachten' en leeftijd van patiënten in de populatie.

\begin{tabular}{lccc}
\hline \multirow{2}{*}{11 minst ernstige klachten } & $\%$ & $\begin{array}{c}\text { 46 jaar } \\
\%\end{array}$ & $\begin{array}{c}\text { Totagl } \\
\%\end{array}$ \\
\hline Hoofdpijn & 20 & 26 & 22 \\
Moeheid & 10 & 9 & 10 \\
Nervositas & 16 & 15 & 16 \\
Slapeloosheid & 2 & 6 & 4 \\
Transpireren & 1 & 3 & 2 \\
Verstopte neus & 6 & 3 & 5 \\
Te dik & 2 & 2 & 2 \\
Eerste pilconsult & 4 & 0 & 2 \\
Spierpijn & 17 & 31 & 21 \\
Jeuk & 6 & 3 & 5 \\
Anticonceptieproblemen & 17 & 2 & 13 \\
\hline Totaal & $100(\mathrm{~N}=342)$ & $100(\mathrm{~N}=149)$ & $100(\mathrm{~N}=491)$ \\
\hline Chijkwadraat $=45,22$ & $\mathrm{P}<0,001$ & &
\end{tabular}


Tabe1 3.4.3.6. Verband tussen ,11 meest emstige klachten" en geslacht van patienten in de populatie.

\begin{tabular}{lccc}
\hline H1 meest ernstige klachten & $\begin{array}{c}\text { Vrouw } \\
\%\end{array}$ & $\begin{array}{c}\text { Man } \\
\%\end{array}$ & $\begin{array}{c}\text { Totaal } \\
\%\end{array}$ \\
\hline Oorpijn & 8 & 7 & 8 \\
Slecht horen & 6 & 7 & 7 \\
Benawwdheid & 8 & 10 & 9 \\
Pijn op de borst & 7 & 12 & 10 \\
Dikke enkels & 5 & 1 & 3 \\
Braken & 5 & 6 & 5 \\
Maagzuur & 1 & 2 & 2 \\
Anaalklachten & 3 & 2 & 3 \\
Pijn bij plassen & 18 & 6 & 12 \\
Knobbeltje & 17 & 11 & 14 \\
Gewrichtspijn & 22 & 36 & 29 \\
Total & $100(\mathrm{~N}=230)$ & $100(\mathrm{~N}=219)$ & $100(\mathrm{~N}=449)$ \\
\hline
\end{tabular}

Chi-kwadrat $=33,53 \quad P<0,001$

Tabel 3.4.3.7. Verband tussen ,11 minst ernstige klachten' en geslacht van patiënten in de populatie.

\begin{tabular}{lccc}
\hline & $\begin{array}{c}\text { Vrouw } \\
\text { 11 minst ernstige klachten }\end{array}$ & $\begin{array}{c}\text { Man } \\
\%\end{array}$ & $\begin{array}{c}\text { Totaal } \\
\%\end{array}$ \\
\hline Hoofdpijn & 23 & 19 & 22 \\
Moeheid & 9 & 11 & 10 \\
Norvositas & 15 & 17 & 16 \\
Slapeloosheid & 3 & 4 & 3 \\
Transpireren & 2 & 1 & 1 \\
Verstopte neus & 5 & 6 & 5 \\
Te dik & 3 & 0 & 2 \\
Eerste pilconsult & 4 & 0 & 2 \\
Spierpin & 15 & 31 & 21 \\
Jeuk & 3 & 9 & 5 \\
Anticonceptieproblemen & 19 & 2 & 13 \\
Total & $100(\mathrm{~N}=318)$ & $100(\mathrm{~N}=172)$ & $100(\mathrm{~N}=490)$ \\
\hline Chi-kwadrat $=58,67$ & $\mathrm{P}<0,001$ & &
\end{tabular}


Tabel 3.4.4.2. Verband tussen ,karakter van de klacht' en leftijd van patienten in de populatie.

\begin{tabular}{lccc}
\hline & $\begin{array}{c}17-45 \text { jaar } \\
\%\end{array}$ & $\begin{array}{c}\text { 46 jaar } \\
\%\end{array}$ & $\begin{array}{c}\text { Totaal } \\
\%\end{array}$ \\
\hline Somatische klachten & 69 & 68 & 68 \\
Psychische klachten & 18 & 16 & 17 \\
Psycho-somatische klachten & 10 & 15 & 12 \\
Maatschappelijke klachten & 4 & 1 & 3 \\
\hline Total & $100(\mathrm{~N}=1311)$ & $100(\mathrm{~N}=670)$ & $100(\mathrm{~N}=1981)$ \\
\hline Chi-kwadraat $=21,43$ & $\mathrm{P}<0,001$ & &
\end{tabular}

Tabel 3.4.4.3. Verband tussen "karakter van de klacht' en geslacht van patiënten in de populatie.

\begin{tabular}{lccc}
\hline & $\begin{array}{c}\text { Vrouw } \\
\%\end{array}$ & Man & Totalal \\
& $\%$ & $\%$ & $\%$ \\
\hline Somatische klachten & 64 & 74 & 68 \\
Psychische klachten & 18 & 16 & 17 \\
Psycho-somatische klachten & 14 & 10 & 12 \\
Mratschappelijke klachten & 4 & 1 & 3 \\
\hline Totaal & $100(\mathrm{~N}=1135)$ & $100(\mathrm{~N}=845)$ & $100(\mathrm{~N}=1980)$ \\
\hline
\end{tabular}

Chi-kwadraat $=29,67 \quad P<0,001$

Tabel 3.4.4.4. Verband tussen, karakter wan de klacht' en leeftijd van vrouwen in de populatic.

\begin{tabular}{lccc}
\hline & $17-45$ jaar & $\begin{array}{c}46 \\
\%\end{array}$ & jaar \\
& $\%$ & 62 & $\%$ \\
\hline Somatische klachten & 65 & 18 & 64 \\
Psychische klachten & 18 & 18 & 18 \\
Psycho-somatische klachten & 12 & 1 & 14 \\
Maatschappelijke klachten & 5 & $100(\mathrm{~N}=364)$ & $100(\mathrm{~N}=1121)$ \\
\hline Totaal & $100(\mathrm{~N}=757)$ & 4 \\
\hline
\end{tabular}

Chi-kwadraat $=18,39 \quad \mathrm{P}<0,001$ 
Tabel 3.4.4.5. Verband tussen ,karakter van de klacht' en consultfrequenties van patienten in de populatie.

\begin{tabular}{lcccc}
\hline Consultfrequenties & $\begin{array}{c}\text { Weinig } \\
\%\end{array}$ & $\begin{array}{c}\text { Normaal } \\
\%\end{array}$ & $\begin{array}{c}\text { Vaak } \\
\%\end{array}$ & $\begin{array}{c}\text { Totaal } \\
\%\end{array}$ \\
\hline Somatische klachten & 77 & 72 & 48 & 68 \\
Psychische klachten & 14 & 14 & 28 & 17 \\
Psycho-somatische klachten & 7 & 12 & 21 & 12 \\
Maatschappelijke klachten & 3 & 2 & 3 & 3 \\
\hline Totaal & 100 & 100 & 100 & 100 \\
& $(\mathrm{~N}=668)$ & $(\mathrm{N}=891)$ & $(\mathrm{N}=442)$ & $(\mathrm{N}=2001)$ \\
\hline
\end{tabular}

Kendall's Tau $C=0,15 \quad P<0,001$

Tabel 3.4.5.2. Verband tussen, reden van consultatie" en geslacht van patiènten in de populatie.

\begin{tabular}{lccc}
\hline & $\begin{array}{c}\text { Vrouw } \\
\%\end{array}$ & $\begin{array}{c}\text { Man } \\
\%\end{array}$ & $\begin{array}{c}\text { Totaal } \\
\%\end{array}$ \\
\hline Pijn & 23 & 28 & 25 \\
Fysiek hinderlijk & 20 & 20 & 20 \\
Sociaal hinderlijk & 3 & 3 & 3 \\
Ongerust & 24 & 15 & 20 \\
Klacht verergert & 4 & 6 & 5 \\
Gaat niet spontaan over & 14 & 14 & 14 \\
Gestuurd & 3 & 3 & 3 \\
Erwaring met klacht & 5 & 5 & 5 \\
Andere reden dan klacht & 5 & 2 & 2 \\
Verzuimbehoefte & 0 & 4 & $100(\mathrm{~N}=2040)$ \\
Totaal & $100(\mathrm{~N}=1166)$ & $100(\mathrm{~N}=874)$ \\
\hline Chi-kwadraat $=69,74$ & $\mathrm{P}<0,001$ & &
\end{tabular}


Tabel 3.4.5.3. Verband tussen ,reden van consultatie' en leeftijd van mamen in de populatie.

\begin{tabular}{|c|c|c|c|}
\hline & 17-45 jaar & $\begin{array}{c}\geqslant 6 \text { jaar } \\
\%\end{array}$ & $\begin{array}{c}\text { Totalal } \\
\%\end{array}$ \\
\hline Pijn & 31 & 23 & 28 \\
\hline Fysiek hinderlijk & 18 & 24 & 20 \\
\hline Sociaal hinderlijk & 2 & 4 & 3 \\
\hline Ongerust & 14 & 17 & 15 \\
\hline Kllacht verergert & 7 & 4 & 6 \\
\hline Gaat niet spontaan over & 13 & 14 & 14 \\
\hline Gestuurd & 3 & 3 & 3 \\
\hline Ervaring met klacht & 6 & 4 & 5 \\
\hline Andere reden dan klacht & 2 & 4 & 2 \\
\hline Verzuimbehoefte & 4 & 3 & 4 \\
\hline Totaal & $100(\mathrm{~N}=559)$ & $100(\mathrm{~N}=306)$ & $100(\mathrm{~N}=865)$ \\
\hline
\end{tabular}

Chi-kwadraat $=17,68 \quad P<0,1$

Tabel 3.4.5.4. Verband tussen, ,reden van consultatie" en leeftijd van vrouwen in de populatie.

\begin{tabular}{lccc}
\hline & $\begin{array}{c}17-45 \text { jaar } \\
\%\end{array}$ & $\begin{array}{c}\text { 46 jaar } \\
\%\end{array}$ & $\begin{array}{c}\text { Totaal } \\
\%\end{array}$ \\
\hline Pijn & 24 & 21 & 23 \\
Fysiek himderlijk & 19 & 20 & 20 \\
Social hinderlijk & 4 & 2 & 3 \\
Ongerust & 25 & 24 & 24 \\
Klacht verergert & 3 & 4 & 4 \\
Gatat niet spontaan over & 12 & 17 & 14 \\
Gestuurd & 3 & 3 & 3 \\
Ervaring met klacht & 4 & 6 & 5 \\
Andere reden dan klacht & 6 & 3 & 5 \\
Verzuimbehoefte & 1 & 0 & 0 \\
\hline Totaal & $100(\mathrm{~N}=777)$ & $100(\mathrm{~N}=375)$ & $100(\mathrm{~N}=1152)$ \\
\hline
\end{tabular}

Chi-kwadraat $=18,20 \quad P<0,1$ 
Tabel 3.4.5.6. Verband tussen, reden van consultatie en consultfrequenties van patienten in de populatie.

\begin{tabular}{lcccc}
\hline Consult frequenties & $\begin{array}{c}\text { Weinig } \\
\%\end{array}$ & $\begin{array}{c}\text { Normaal } \\
\%\end{array}$ & $\begin{array}{c}\text { Vaak } \\
\%\end{array}$ & $\begin{array}{c}\text { Totaal } \\
\%\end{array}$ \\
\hline Pijn & 28 & 25 & 22 & 25 \\
Fysiek hinderlijk & 19 & 20 & 21 & 20 \\
Social hinderijik & 4 & 3 & 1 & 3 \\
Ongerust & 18 & 20 & 25 & 20 \\
Klacht verergert & 6 & 4 & 4 & 5 \\
Gaat niet spontaan over & 14 & 13 & 12 & 13 \\
Gestuidrd & 4 & 3 & 2 & 3 \\
Ervaring met klacht & 4 & 6 & 5 & 5 \\
Andere reden dan klacht & 3 & 4 & 4 & 4 \\
Verzuimbehoefte & $\mathbb{1}$ & 1 & 4 & 2 \\
Totaal & 100 & 100 & 100 & 100 \\
& $(\mathrm{~N}=698)$ & $(\mathrm{N}=912)$ & $(\mathrm{N}=452)$ & $(\mathrm{N}=2062)$ \\
\hline
\end{tabular}

Kendall's Tau $C=0,03 \quad P<0,1$

Tabel 3.4.5.7. Verband tussen, reden van consultatie' en karakter van de klacht, van patiënten in de populatie.

\begin{tabular}{lccccc}
\hline & $\begin{array}{c}\text { Soma- } \\
\text { tisch } \\
\%\end{array}$ & $\begin{array}{c}\text { Psy- } \\
\text { chisch } \\
\%\end{array}$ & $\begin{array}{c}\text { Psycho- } \\
\text { soma- } \\
\text { tisch } \\
\%\end{array}$ & $\begin{array}{c}\text { Maat- } \\
\text { schap- } \\
\text { pelijk } \\
\%\end{array}$ & $\begin{array}{c}\text { Totaal } \\
\%\end{array}$ \\
\hline Pijn & 32 & 8 & 24 & 0 & 26 \\
Fysiek hinderlijk & 24 & 9 & 20 & 12 & 20 \\
Sociaal hinderlijk & 2 & 4 & 2 & 19 & 3 \\
Ongerust & 13 & 38 & 30 & 33 & 20 \\
Klacht verergert & 5 & 5 & 3 & 2 & 5 \\
Gaat niet spontaan over & 14 & 14 & 11 & 6 & 13 \\
Gestuurd & 3 & 6 & 2 & 6 & 3 \\
Ervaring met klacht & 5 & 5 & 4 & 10 & 5 \\
Andere reden dan klacht & 3 & 6 & 4 & 8 & 4 \\
Verzuimbehoefte & 1 & 6 & 0 & 6 & 2 \\
\hline Totaal & 100 & 100 & 100 & 100 & 100 \\
& $\quad \mathrm{~N}=1372)$ & $(\mathrm{N}=342)$ & $(\mathrm{N}=238)$ & $(\mathrm{N}=52)$ & $(\mathrm{N}=2004)$ \\
\hline Chi-kwadraat $=352,02$ & $\mathrm{P}<0,001$ & & &
\end{tabular}


Tabel 3.5.1.2. Verband tussen samenwerkingsvorm en leeftijd van patiènten in de populatie.

\begin{tabular}{lccc}
\hline & $\begin{array}{c}17-45 \text { jaar } \\
\%\end{array}$ & $\begin{array}{c}46 \text { jaar } \\
\%\end{array}$ & $\begin{array}{c}\text { Totaal } \\
\%\end{array}$ \\
\hline Solopraktijken & 74 & 69 & 72 \\
Associaties & 26 & 32 & 28 \\
\hline Totaal & $100(\mathrm{~N}=1352)$ & $100(\mathrm{~N}=693)$ & $100(\mathrm{~N}=2045)$ \\
\hline
\end{tabular}

Chi-kwadraat $=6,43 \quad P<0,1$

Tabel 3.5.1.3. Verband tussen samenwerkingsvorm en leeftijd van vrouwen in de populatie.

\begin{tabular}{lccc}
\hline & $\begin{array}{c}17-45 \text { jaar } \\
\%\end{array}$ & $\begin{array}{c}46 \text { jaar } \\
\%\end{array}$ & $\begin{array}{c}\text { Totaal } \\
\%\end{array}$ \\
\hline Solopraktijken & 75 & 69 & 73 \\
Associaties & 25 & 31 & 27 \\
\hline Totaal & $100(\mathrm{~N}=779)$ & $100(\mathrm{~N}=375)$ & $100(\mathrm{~N}=1154)$ \\
\hline
\end{tabular}

Chi-kwadraat $=3,27 \quad \mathrm{P}<0,1$

Tabel 3.5.1.4. Verband tussen samenwerkingsworm en opleidingsniveau van patién. ten in de populatie.

\begin{tabular}{lcccc}
\hline Opleiding & $\begin{array}{c}\text { Laag } \\
\%\end{array}$ & $\begin{array}{c}\text { Midden } \\
\%\end{array}$ & $\begin{array}{c}\text { Hoog } \\
\%\end{array}$ & $\begin{array}{c}\text { Totaal } \\
\%\end{array}$ \\
\hline Solopraktijken & 77 & 71 & 41 & 72 \\
Associaties & 23 & 30 & 59 & 28 \\
\hline Totaal & 100 & 100 & 100 & 100 \\
& $(\mathrm{~N}=1291)$ & $(\mathrm{N}=580)$ & $(\mathrm{N}=183)$ & $(\mathrm{N}=2054)$ \\
\hline
\end{tabular}

Kendall's Tau $C=0,16 \quad P<0,001$ 
Tabel 3.5.2.3. Verband tussen spreekuurworm en geslacht van patiënten in de populatie.

\begin{tabular}{lccc}
\hline & $\begin{array}{c}\text { Vrouw } \\
\%\end{array}$ & $\begin{array}{c}\text { Man } \\
\%\end{array}$ & $\begin{array}{c}\text { Totaal } \\
\%\end{array}$ \\
\hline Vrij spreekuur & 27 & 31 & 29 \\
Afspraakspreekuur & 73 & 69 & 71 \\
\hline Totaal & $100(\mathrm{~N}=1169)$ & $100(\mathrm{~N}=875)$ & $100(\mathrm{~N}=2044)$ \\
\hline Chi-kwadraat $=3,99$ & $\mathrm{P}<0,1$ & &
\end{tabular}

Tabel 3.5.2.4. Verband tussen spreekuurvorm en opleidingsniveau van patiënten in de populatie.

\begin{tabular}{lcccc}
\hline Opleiding & $\begin{array}{c}\text { Laag } \\
\%\end{array}$ & $\begin{array}{c}\text { Midden } \\
\%\end{array}$ & $\begin{array}{c}\text { Hoog } \\
\%\end{array}$ & $\begin{array}{c}\text { Totaal } \\
\%\end{array}$ \\
\hline Vrij spreekuur & 29 & 28 & 21 & 28 \\
Afspraakspreekuur & 71 & 72 & 79 & 72 \\
\hline Totaal & 100 & 100 & 100 & 100 \\
& $(\mathrm{~N}=1291)$ & $(\mathrm{N}=580)$ & $(\mathrm{N}=183)$ & $(\mathrm{N}=2054)$ \\
\hline
\end{tabular}

Kendall's Tau $C=0,03 \quad \mathbb{P}<0,1$

Tabel 3.5.3.3. Verband tussen praktijkgrootte en opleidingsniveau van patiënten in do populatie.

\begin{tabular}{lcccc}
\hline $\begin{array}{l}\text { Opleiding } \\
\text { Praktijkgrootte }\end{array}$ & $\begin{array}{c}\text { Laag } \\
\%\end{array}$ & $\begin{array}{c}\text { Midden } \\
\%\end{array}$ & $\begin{array}{c}\text { Hoog } \\
\%\end{array}$ & $\begin{array}{c}\text { Totaall } \\
\%\end{array}$ \\
\hline <2000 patiënten & 10 & 10 & 8 & 10 \\
2000 t.m. 3000 patiënten & 36 & 31 & 50 & 36 \\
3001 t.m. 4000 patiënten & 44 & 51 & 38 & 45 \\
$>4000$ patiënten & 11 & 8 & 4 & 9 \\
\hline Totaal & 100 & 100 & 100 & 100 \\
& $(\mathrm{~N}=1.291)$ & $(\mathrm{N}=580)$ & $(\mathrm{N}=183)$ & $(\mathrm{N}=2054)$ \\
\hline
\end{tabular}

Kendall"s Tau $\mathrm{C}=-0,03 \quad \mathrm{P}<0,1$ 
Tabel 3.5.4.2. Verband tussen leeftijd huisarts en opleidingsniveau van patiènten in de populatie.

\begin{tabular}{lcccc}
\hline Opleiding & $\begin{array}{c}\text { Laag } \\
\%\end{array}$ & $\begin{array}{c}\text { Midden } \\
\%\end{array}$ & $\begin{array}{c}\text { Hoog } \\
\%\end{array}$ & $\begin{array}{c}\text { Totaal } \\
\%\end{array}$ \\
\hline Huisantsen $<40$ jaar & 47 & 55 & 61 & 50 \\
Huisartsen $\geqslant 40$ jaar & 53 & 45 & 39 & 50 \\
\hline Totaal & 100 & 100 & 100 & 100 \\
& $(\mathrm{~N}=1291)$ & $(\mathrm{N}=580)$ & $(\mathrm{N}=183)$ & $(\mathrm{N}=2054)$
\end{tabular}

Kendall's Tau $\mathrm{C}=-0,09 \quad \mathrm{P}<0,001$

Tabel 4.2.1.1. Verband tussen uitstelduar en geslacht van patiënten in de populatie.

\begin{tabular}{cccc}
\hline Uitstelldur & $\begin{array}{c}\text { Vrouw } \\
\%\end{array}$ & $\begin{array}{c}\text { Man } \\
\%\end{array}$ & $\begin{array}{c}\text { Totaal } \\
\%\end{array}$ \\
\hline 0 & 7 & 12 & 9 \\
1 & 31 & 40 & 35 \\
2 & 31 & 28 & 30 \\
3 & 31 & 20 & 26 \\
\hline Totaal & $100(\mathrm{~N}=1159)$ & $100(\mathrm{~N}=870)$ & $100(\mathrm{~N}=2029)$ \\
\hline
\end{tabular}

Kendall's Tau $C=-0,17 \quad P<0,001$

Tabel 4.2.1.2. Verband tussen uitstelduur en geslacht van jongere patienten in de populatie.

\begin{tabular}{cccc}
\hline Uitstelduur & $\begin{array}{c}\text { Vrouw } \\
\%\end{array}$ & $\begin{array}{c}\text { Man } \\
\%\end{array}$ & $\begin{array}{c}\text { Totaal } \\
\%\end{array}$ \\
\hline 0 & 8 & 13 & 10 \\
1 & 31 & 43 & 36 \\
2 & 32 & 28 & 30 \\
3 & 29 & 16 & 24 \\
\hline Totaal & $100(\mathrm{~N}=771)$ & $100(\mathrm{~N}=555)$ & $100(\mathrm{~N}=1326)$ \\
\hline
\end{tabular}

Kendall's Tau $C=-0,21 \quad \mathrm{P}<0,001$ 
BULAGE II

Tabel 4.2.1.3. Verband tussen uitsteldurur en geslacht van oudere patienten in de populatie.

\begin{tabular}{cccc}
\hline Uitstelduur & $\begin{array}{c}\text { Vrouw } \\
\%\end{array}$ & $\begin{array}{c}\text { Man } \\
\%\end{array}$ & $\begin{array}{c}\text { Totaal } \\
\%\end{array}$ \\
\hline 0 & 5 & 10 & 7 \\
1 & 33 & 35 & 34 \\
2 & 29 & 29 & 29 \\
3 & 33 & 26 & 30 \\
\hline Totaal & $100(\mathrm{~N}=374)$ & $100(\mathrm{~N}=306)$ & $100(\mathrm{~N}=680)$ \\
\hline Kendall's Tau $\mathrm{C}=-0,10$ & $\mathrm{P}<0,1$ &
\end{tabular}

Tabel 4.2.1.4. Verband tussen vitstelduur en geslacht van patienten in de popu* latie met een ,lagere opleiding?.

\begin{tabular}{cccc}
\hline Uitstelduur & $\begin{array}{c}\text { Vrouw } \\
\%\end{array}$ & $\begin{array}{c}\text { Man } \\
\%\end{array}$ & $\begin{array}{c}\text { Totaal } \\
\%\end{array}$ \\
\hline 0 & 8 & 12 & 10 \\
1 & 32 & 42 & 36 \\
2 & 31 & 27 & 29 \\
3 & 29 & 19 & 25 \\
\hline Totaal & $100(\mathrm{~N}=723)$ & $100(\mathrm{~N}=544)$ & $100(\mathrm{~N}=1267)$ \\
\hline
\end{tabular}

Kendall's Tau $C=-0,16 \quad P<0,001$

Tabel 4.2.1.5. Verband tussen uitstelduur en geslacht van patiẻnten in de populatie met een ,midden opleiding".

\begin{tabular}{cccc}
\hline Uitstelduur & $\begin{array}{c}\text { Vrouw } \\
\%\end{array}$ & $\begin{array}{c}\text { Man } \\
\%\end{array}$ & $\begin{array}{c}\text { Totatal } \\
\%\end{array}$ \\
\hline 0 & 6 & 14 & 9 \\
1 & 31 & 40 & 34 \\
2 & 31 & 30 & 31 \\
3 & 32 & 16 & 26 \\
\hline Totaal & $100(\mathrm{~N}=333)$ & $100(\mathrm{~N}=237)$ & $100(\mathrm{~N}=570)$ \\
\hline
\end{tabular}

Kendall's Tau $C=-0,23 \quad P<0,001$ 
Tabel 4.2.1.6. Verband tussen uitsteldurur en geslacht van patienten in de populatie met algemene klachten.

\begin{tabular}{cccc}
\hline Uitstelduur & $\begin{array}{c}\text { Vrouw } \\
\%\end{array}$ & $\begin{array}{c}\text { Man } \\
\%\end{array}$ & $\begin{array}{c}\text { Totaal } \\
\%\end{array}$ \\
\hline 0 & 5 & 13 & 8 \\
1 & 21 & 31 & 25 \\
2 & 42 & 35 & 39 \\
3 & 32 & 21 & 28 \\
\hline Totaal & $100(\mathrm{~N}=255)$ & $100(\mathrm{~N}=162)$ & $100(\mathrm{~N}=417)$ \\
\hline
\end{tabular}

Kendall's Tau $\mathbf{C}=-0,20 \quad \mathbf{P}<0,001$

Tabel 4.2.1.7. Verband tussen uitstelduur en geslacht van patiënten in de populatie met buikklachten.

\begin{tabular}{cccc}
\hline Uitstelduur & $\begin{array}{c}\text { Vrouw } \\
\%\end{array}$ & $\begin{array}{c}\text { Man } \\
\%\end{array}$ & $\begin{array}{c}\text { Totaal } \\
\%\end{array}$ \\
\hline 0 & 8 & 15 & 11 \\
1 & 36 & 41 & 38 \\
2 & 28 & 27 & 27 \\
3 & 28 & 17 & 24 \\
\hline Totaal & $100(\mathrm{~N}=131)$ & $100(\mathrm{~N}=86)$ & $100(\mathrm{~N}=217)$ \\
\hline
\end{tabular}

Kendall's Tau $C=-0,16 \quad P<0,1$

Tabel 4.2.1.8. Verband tussen vitstelduur en geslacht van patiënten in de popu. latie met urogenitaalklachten.

\begin{tabular}{cccc}
\hline Uitstelduur & $\begin{array}{c}\text { Vrouw } \\
\%\end{array}$ & $\begin{array}{c}\text { Man } \\
\%\end{array}$ & $\begin{array}{c}\text { Totaal } \\
\%\end{array}$ \\
\hline 0 & 7 & 30 & 11 \\
1 & 35 & 30 & 34 \\
2 & 15 & 15 & 15 \\
3 & 42 & 25 & 40 \\
\hline Totaal & $100(\mathrm{~N}=123)$ & $100(\mathrm{~N}=20)$ & $100(\mathbb{N}=143)$ \\
\hline
\end{tabular}

Kendall's Tau $\mathrm{C}=-0,1.4 \quad \mathrm{P}<0,1$ 
Tabel 4.2.9. Verband tussen uitsteldur en geslacht van patiënten in de populatie met klachten wan het bewegingsapparaat.

\begin{tabular}{cccc}
\hline Vitsteldunir & $\begin{array}{c}\text { Vrouw } \\
\%\end{array}$ & $\begin{array}{c}\text { Man } \\
\%\end{array}$ & $\begin{array}{c}\text { Total } \\
\%\end{array}$ \\
\hline 0 & 6 & 15 & 11 \\
1 & 32 & 35 & 34 \\
2 & 32 & 31 & 31 \\
3 & 30 & 19 & 24 \\
\hline Totaal & $100(\mathrm{~N}=174)$ & $100(\mathrm{~N}=236)$ & $100(\mathrm{~N}=410)$ \\
\hline
\end{tabular}

Kendall's Tau $\mathrm{C}=-0,18 \quad \mathrm{P}<0,001$

Tabel 4.22.1. Verband tussen uitstelduur en leeftijd wan patiënten in de populatie.

\begin{tabular}{cccc}
\hline Uitsteldunr & $\begin{array}{c}17-45 \mathrm{jr} . \\
\%\end{array}$ & $\begin{array}{c}\text { 46 jr. } \\
\%\end{array}$ & $\begin{array}{c}\text { Totaal } \\
\%\end{array}$ \\
\hline 0 & 10 & 7 & 9 \\
1 & 36 & 34 & 35 \\
2 & 30 & 29 & 30 \\
3 & 24 & 30 & 26 \\
\hline Totaal & $100(\mathrm{~N}=1339)$ & $100(\mathrm{~N}=692)$ & $100(\mathrm{~N}=2031)$ \\
\hline
\end{tabular}

Kendall's Tau $C=0,07 \quad P<0,001$

Tabel 4.2.2.2. Verband tussen tuitstelduur en leeftijd van mannen in de populatie.

\begin{tabular}{cccc}
\hline Uitsteldutur & $\begin{array}{c}17-45 \mathrm{jr} . \\
\%\end{array}$ & $\begin{array}{c}\text { 46 jr. } \\
\%\end{array}$ & $\begin{array}{c}\text { Totaal } \\
\%\end{array}$ \\
\hline 0 & 13 & 9 & 12 \\
1 & 43 & 35 & 40 \\
2 & 28 & 29 & 28 \\
3 & 16 & 27 & 20 \\
\hline Totalal & $100(\mathrm{~N}=555)$ & $100(\mathrm{~N}=306)$ & $100(\mathrm{~N}=861)$ \\
\hline
\end{tabular}

Kendall's Tau $C=0,14 \quad P<0,001$

176 
Tabel 4.2.2.3. Verband tussen uitstelduur en leeftijd var patienten in de populatie met een, lagere opleiding".

\begin{tabular}{cccc}
\hline Uitstelduur & $\begin{array}{c}17-45 \mathrm{jr} . \\
\%\end{array}$ & $\begin{array}{c}\geqslant \mathrm{j} . \\
\%\end{array}$ & $\begin{array}{c}\text { Totaal } \\
\%\end{array}$ \\
\hline 0 & 10 & 7 & 9 \\
1 & 37 & 35 & 36 \\
2 & 31 & 28 & 30 \\
3 & 22 & 30 & 25 \\
\hline Totaal & $100(\mathrm{~N}=798)$ & $100(\mathrm{~N}=473)$ & $100(\mathrm{~N}=1271)$ \\
\hline
\end{tabular}

Kendall's Tau $C=0,09 \quad P<0,01$

Tabel 4.2.2.4. Verband tussen uitstelduur en leeftijd van patiënten in de populatie met een ,hogere opleiding".

\begin{tabular}{cccc}
\hline Uitstelduur & $\begin{array}{c}17-45 \mathrm{jr} . \\
\%\end{array}$ & $\begin{array}{c}\text { i } \\
\%\end{array}$ & $\begin{array}{c}\text { Totaal } \\
\%\end{array}$ \\
\hline 0 & 11 & 6 & 9 \\
1 & 29 & 26 & 28 \\
2 & 28 & 29 & 29 \\
3 & 31 & 39 & 34 \\
\hline Totaal & $100(\mathrm{~N}=116)$ & $100(\mathrm{~N}=62)$ & $100(\mathrm{~N}=178)$ \\
\hline
\end{tabular}

Kendall's Tau $C=0,10 \quad P<0,1$

Tabel 4.2.2.5. Verband tussen uitstelduur en leeftijd van patienten in de populatie met algemene klachten.

\begin{tabular}{cccc}
\hline Uitstelduur & $\begin{array}{c}17-45 \mathrm{jr} . \\
\%\end{array}$ & $\begin{array}{c}46 \mathrm{jr} \\
\%\end{array}$ & $\begin{array}{c}\text { Totaal } \\
\%\end{array}$ \\
\hline 0 & 10 & 3 & 7 \\
1 & 27 & 23 & 25 \\
2 & 40 & 38 & 40 \\
3 & 23 & 36 & 28 \\
\hline Tiotaal & $100(\mathrm{~N}=263)$ & $100(\mathrm{~N}=152)$ & $100(\mathrm{~N}=415)$ \\
\hline
\end{tabular}

Kendall"s Tau $C=0,16 \quad P<0,01$ 
Tabel 4.2.2.6. Verband tussen uitstelduur en leeftijd van patiënten in de populatie met klachten van het bewegingsapparaat

\begin{tabular}{cccc}
\hline & $\begin{array}{c}17-45 \mathrm{jr} . \\
\%\end{array}$ & $\begin{array}{c}46 \mathrm{jr} . \\
\%\end{array}$ & $\begin{array}{c}\text { Totaal } \\
\%\end{array}$ \\
\hline 0 & 12 & 8 & 10 \\
1 & 35 & 30 & 34 \\
2 & 34 & 30 & 32 \\
3 & 19 & 32 & 24 \\
\hline Totalstelduur & $100(\mathrm{~N}=255)$ & $100(\mathrm{~N}=158)$ & $100(\mathrm{~N}=413)$ \\
\hline
\end{tabular}

Kendall's Tau $C=0,13 \quad P<0,01$

Tabel 4.2.2.7. Verband tussen uitstelduur en leeftijd wan patiënten in de populatie met ,k.n.o-klachten of klachten van de luchtwegen'.

\begin{tabular}{cccc}
\hline Uitstelduur & $\begin{array}{c}17-45 \mathrm{jr} . \\
\%\end{array}$ & $\begin{array}{c}\text { 46 jr. } \\
\%\end{array}$ & $\begin{array}{c}\text { Totaal } \\
\%\end{array}$ \\
\hline 0 & 13 & 6 & 10 \\
1 & 57 & 49 & 55 \\
2 & 22 & 28 & 24 \\
3 & 8 & 17 & 11 \\
\hline Totaal & $100(\mathrm{~N}=268)$ & $100(\mathrm{~N}=138)$ & $100(\mathrm{~N}=406)$ \\
\hline
\end{tabular}

Kendall's Tau $C=0,16 \quad P<0,001$

Tabel 4.2.3.1. Verband tussen uitstelduur en opleidingsniveau van patiënten in de populatie.

\begin{tabular}{ccccc}
\hline $\begin{array}{c}\text { Opleiding } \\
\text { Uitsteldutur }\end{array}$ & $\begin{array}{c}\text { Laag } \\
\%\end{array}$ & $\begin{array}{c}\text { Midden } \\
\%\end{array}$ & $\begin{array}{c}\text { Hoog } \\
\%\end{array}$ & $\begin{array}{c}\text { Totaal } \\
\%\end{array}$ \\
\hline 0 & 9 & 9 & 10 & 9 \\
1 & 37 & 35 & 27 & 35 \\
2 & 30 & 31 & 29 & 30 \\
3 & 24 & 25 & 34 & 26 \\
Totaal & $100(\mathrm{~N}=1286)$ & $100(\mathrm{~N}=573)$ & $100(\mathrm{~N}=182)$ & $100(\mathrm{~N}=2041)$
\end{tabular}

Kendall's Tau $C=0,04 \quad P<0,1$ 
Tabel 4.2.3.2. Verband tussen uitstelduur en opleidingsniveau van jongere patiënten in de populatie.

\begin{tabular}{ccccc}
\hline $\begin{array}{c}\text { Opleiding } \\
\text { Uitstelduur }\end{array}$ & $\begin{array}{c}\text { Laag } \\
\%\end{array}$ & $\begin{array}{c}\text { Midden } \\
\%\end{array}$ & $\begin{array}{c}\text { Hoog } \\
\%\end{array}$ & $\begin{array}{c}\text { Totaal } \\
\%\end{array}$ \\
\hline 0 & 10 & 10 & 11 & 10 \\
1 & 37 & 35 & 29 & 36 \\
2 & 31 & 30 & 29 & 30 \\
3 & 22 & 25 & 31 & 24 \\
\hline Totaal & $100(\mathrm{~N}=798)$ & $100(\mathrm{~N}=415)$ & $100(\mathrm{~N}=116)$ & $100(\mathrm{~N}=1329)$ \\
\hline
\end{tabular}

Kendall's Tau $C=0,04 \quad P<0,1$

Tabel 4.2.3.3. Verband tussen uitstelluur en opleidingsniweau van vrouwen in de populatie.

\begin{tabular}{ccccc}
\hline $\begin{array}{c}\text { Opleiding } \\
\text { Uitstelduur }\end{array}$ & $\begin{array}{c}\text { Laag } \\
\%\end{array}$ & $\begin{array}{c}\text { Midden } \\
\%\end{array}$ & $\begin{array}{c}\text { Hoog } \\
\%\end{array}$ & $\begin{array}{c}\text { Totaal } \\
\%\end{array}$ \\
\hline 0 & 8 & 6 & 7 & 7 \\
1 & 32 & 31 & 29 & 31 \\
2 & 31 & 31 & 27 & 31 \\
3 & 29 & 32 & 37 & 31 \\
\hline Totaal & $100(\mathrm{~N}=723)$ & $100(\mathrm{~N}=333)$ & $100(\mathrm{~N}=93)$ & $100(\mathrm{~N}=1149)$ \\
\hline
\end{tabular}

Kendall's Tau $C=0,04 \quad P<0,1$

Tabel 4.2.3.4. Verband tussen uitstelduur en opleidingsniveau van patiënten in de populatie met algemene klachten.

\begin{tabular}{ccccc}
\hline $\begin{array}{c}\text { Opleiding } \\
\text { Uitstelduur }\end{array}$ & $\begin{array}{c}\text { Laag } \\
\%\end{array}$ & $\begin{array}{c}\text { Midden } \\
\%\end{array}$ & $\begin{array}{c}\text { Hoog } \\
\%\end{array}$ & $\begin{array}{c}\text { Totaal } \\
\%\end{array}$ \\
\hline 0 & 7 & 7 & 9 & 8 \\
1 & 29 & 19 & 18 & 25 \\
2 & 38 & 43 & 36 & 39 \\
3 & 26 & 31 & 37 & 28 \\
\hline Totaal & $100(\mathrm{~N}=266)$ & $100(\mathrm{~N}=121)$ & $100(\mathrm{~N}=33)$ & $100(\mathrm{~N}=420)$ \\
\hline
\end{tabular}

Kendall's Tau $\mathrm{C}=0,08 \quad \mathbf{P}<0,1$ 
Tabel 4.2.3.5. Verband tussen uitstelduur en opleidingsniveau van patienten in de populatie met hartkiachten.

\begin{tabular}{ccccc}
\hline $\begin{array}{c}\text { Oppleiding } \\
\text { Uitstelduur }\end{array}$ & $\begin{array}{c}\text { Laag } \\
\%\end{array}$ & $\begin{array}{c}\text { Midden } \\
\%\end{array}$ & $\begin{array}{c}\text { Hoog } \\
\%\end{array}$ & $\begin{array}{c}\text { Totaal } \\
\%\end{array}$ \\
\hline 0 & 13 & 13 & 0 & 11 \\
1 & 24 & 22 & 12 & 22 \\
2 & 23 & 35 & 19 & 24 \\
3 & 40 & 30 & 69 & 43 \\
\hline Totaal & $100(\mathrm{~N}=84)$ & $100(\mathrm{~N}=23)$ & $100(\mathrm{~N}=16)$ & $100(\mathrm{~N}=123)$ \\
\hline
\end{tabular}

Kendall's Tru $C=0,1 \quad P<0,1$

Tabel 4.2.3.6. Verband tussen uitstelduur en opleidingsniveau van patiënten in de populatie met, k.n.o.-klachten of klachtem van de luchtwegen".

\begin{tabular}{ccccc}
\hline $\begin{array}{c}\text { Opleiding } \\
\text { Uitsteldur }\end{array}$ & $\begin{array}{c}\text { Laag } \\
\%\end{array}$ & $\begin{array}{c}\text { Midden } \\
\%\end{array}$ & $\begin{array}{c}\text { Hoog } \\
\%\end{array}$ & $\begin{array}{c}\text { Totaal } \\
\%\end{array}$ \\
\hline 0 & 10 & 10 & 17 & 10 \\
1 & 59 & 54 & 30 & 55 \\
2 & 23 & 25 & 28 & 24 \\
3 & 8 & 11 & 25 & 11 \\
\hline Totaal & $100(\mathrm{~N}=255)$ & $100(\mathrm{~N}=113)$ & $100(\mathrm{~N}=40)$ & $100(\mathrm{~N}=408)$ \\
\hline
\end{tabular}

Kendall's Tau $\mathrm{C}=0,07 \quad \mathrm{P}<0,1$

Tabel 4.2.4.1. Verband tussen uitstelduur en consultfrequenties van oudere patiënten in de populatie.

\begin{tabular}{|c|c|c|c|c|}
\hline $\begin{array}{l}\text { Consulten } \\
\text { per jaar } \\
\text { Uitstelduur }\end{array}$ & $\begin{array}{c}\text { Weinig } \\
(0-3 \text { maal }) \\
\%\end{array}$ & $\begin{array}{c}\text { Normaal } \\
(4-6 \text { maal }) \\
\%\end{array}$ & $\begin{array}{l}\text { Vaak } \\
\geqslant 7 \text { maal } \\
\%\end{array}$ & $\begin{array}{c}\text { Totaal } \\
\%\end{array}$ \\
\hline 0 & 7 & 5 & 11 & 7 \\
\hline 1 & 29 & 36 & 36 & 34 \\
\hline 2 & 29 & 32 & 24 & 29 \\
\hline 3 & 35 & 27 & 29 & 30 \\
\hline Totaal & $100(\mathbb{N}=191)$ & $100(\mathrm{~N}=306)$ & $100(\mathrm{~N}=193)$ & $100(\mathrm{~N}=690)$ \\
\hline
\end{tabular}


Tabel 4.2.4.2. Verband tussen uitsteldur en consultfrequenties van patienten in de populatie met ,hogere opleidingen".

\begin{tabular}{ccccc}
\hline $\begin{array}{l}\text { Consulten } \\
\text { per jaar } \\
\text { Uitstelduur }\end{array}$ & $\begin{array}{c}\text { Weinig } \\
(0-3 \text { maal })\end{array}$ & $\begin{array}{c}\text { Normaal } \\
(4-6 \text { maal }) \\
\%\end{array}$ & $\begin{array}{c}\text { Vaak } \\
\% \text { maal } \\
\%\end{array}$ & Totaal \\
\hline 0 & 14 & 5 & 15 & $\%$ \\
1 & 18 & 34 & 33 & 10 \\
2 & 27 & 31 & 26 & 29 \\
3 & 41 & 30 & 26 & 34 \\
\hline Totaal & $100(\mathrm{~N}=73)$ & $100(\mathrm{~N}=82)$ & $100(\mathrm{~N}=27)$ & $100(\mathrm{~N}=182)$ \\
\hline
\end{tabular}

Kendall's Tau $\mathrm{C}=-0,10 \quad \mathrm{P}<0,1$

Tabel 4.2.4.3. Verband tussen uitstelduur en consultfrequenties van patiënten in de populatie met hartklachten.

\begin{tabular}{|c|c|c|c|c|}
\hline $\begin{array}{l}\text { Consulten } \\
\text { per jaar } \\
\text { Uitstelduur }\end{array}$ & $\begin{array}{c}\text { Weinig } \\
(0-3 \text { maal }) \\
\%\end{array}$ & $\begin{array}{c}\text { Normaal } \\
\text { (4-6 mat) } \\
\%\end{array}$ & $\begin{array}{c}\text { Vaak } \\
\geqslant 7 \text { maal } \\
\% \neq\end{array}$ & $\begin{array}{c}\text { Totaal } \\
\%\end{array}$ \\
\hline 0 & 4 & 10 & 17 & 11 \\
\hline 1 & 33 & 13 & 28 & 23 \\
\hline 2 & 13 & 30 & 21 & 23 \\
\hline 3 & 50 & 47 & 34 & 43 \\
\hline Totaal & $100(\mathrm{~N}=24)$ & $100(\mathrm{~N}=53)$ & $100(N=47)$ & $100(\mathrm{~N}=124)$ \\
\hline
\end{tabular}

Tabel 4.2.4.4. Verband tussen uitstelduur en consultfrequenties van patiënten in de populatie met gezwellen.

\begin{tabular}{lcccc}
\hline $\begin{array}{l}\text { Consulten } \\
\text { per jaar }\end{array}$ & $\begin{array}{c}\text { Weinig } \\
\text { Uitstelduur }\end{array}$ & $\begin{array}{c}\text { Normal } \\
(4-6 \text { mal })\end{array}$ & $\begin{array}{c}\text { Vaak } \\
\%\end{array}$ & $\begin{array}{c}7 \text { maal } \\
\%\end{array}$ \\
\hline 0 & 7 & 0 & 12 & $\%$ \\
1 & 24 & 22 & 63 & 5 \\
2 & 28 & 59 & 13 & 28 \\
3 & 41 & 19 & 12 & 39 \\
\hline Totaal & $100(\mathrm{~N}=29)$ & $100(\mathrm{~N}=27)$ & $100(\mathrm{~N}=8)$ & $100(\mathrm{~N}=64)$ \\
\hline
\end{tabular}

Kendall's Tau $C=-0,21 \quad P<0,1$ 
Tabel 4.2.4.5. Verband tussen uitstelduur en consultfrequenties van patienten in de populatie met, algemene klachten, huidklachten of klachten op sexualiteitsgebied?

\begin{tabular}{ccccc}
\hline $\begin{array}{l}\text { Consulten } \\
\text { per jaar } \\
\text { Uitstelduur }\end{array}$ & $\begin{array}{c}\text { Weinig } \\
(0-3 \mathrm{maal})\end{array}$ & $\begin{array}{c}\text { Normaal } \\
(4-6 \mathrm{maal})\end{array}$ & $\begin{array}{c}\text { Vaak } \\
\% \text { maal }\end{array}$ & Totaal \\
\hline 0 & 8 & $\%$ & $\%$ & $\%$ \\
1 & 24 & 25 & 6 & 86 \\
2 & 32 & 41 & 35 & 36 \\
3 & 36 & 26 & 29 & 30 \\
\hline Totaal & $100(\mathrm{~N}=236)$ & $\mathbf{1 0 0}(\mathrm{N}=297)$ & $100(\mathrm{~N}=136)$ & $100(\mathrm{~N}=669)$ \\
\hline Kendall's Tau $\mathrm{C}=-0,06$ & $\mathrm{P}<0,1$ & &
\end{tabular}

Tabel 4.2.4.6. Verband tussen uitstellduur en consultfrequenties van patiënten in de populatie met buikklachten.

\begin{tabular}{ccccc}
\hline $\begin{array}{l}\text { Consulten } \\
\text { per jaar } \\
\text { Uitstelduur }\end{array}$ & $\begin{array}{c}\text { Weinig } \\
(0-3 \mathrm{maal})\end{array}$ & $\begin{array}{c}\text { Normaal } \\
(4-6 \mathrm{maal}) \\
\%\end{array}$ & $\begin{array}{c}\text { Vaak } \\
\% \text { maal } \\
\%\end{array}$ & Totaal \\
\hline 0 & 16 & 6 & 13 & $\%$ \\
1 & 41 & 41 & 31 & 11 \\
2 & 21 & 30 & 28 & 38 \\
3 & 22 & 23 & 28 & 27 \\
\hline Totaal & $100(\mathrm{~N}=61)$ & $100(\mathrm{~N}=94)$ & $100(\mathrm{~N}=64)$ & $100(\mathrm{~N}=219)$ \\
\hline
\end{tabular}

Kendall's Tau $\mathrm{C}=0,09 \quad \mathrm{P}<0,1$

Tabel 4.2.5.1. Verband tussen uitstelduur en ,stads-plattelandspatiënt" bij patienten in de populatie.

\begin{tabular}{cccc}
\hline Uitstelduur & $\begin{array}{c}\text { Plattelandspatiënt } \\
\%\end{array}$ & $\begin{array}{c}\text { Stadspatiënt } \\
\%\end{array}$ & $\begin{array}{c}\text { Totaal } \\
\%\end{array}$ \\
\hline 0 & 10 & 9 & 9 \\
1 & 32 & 39 & 35 \\
2 & 30 & 29 & 30 \\
3 & 28 & 23 & 26 \\
\hline Totaal & $100(\mathbf{N}=1124)$ & $100(\mathbf{N}=931)$ & $100(\mathbb{N}=2055)$ \\
\hline Kendall's Tat $\mathrm{C}=-0,07$ & $\mathbf{P}<0,01$
\end{tabular}


Tabel 4.2.5.2. Verband tussen uitstelduur en "stads-plattelandspatient" bij jongere patiènten in de populatie.

\begin{tabular}{cccc}
\hline Uitstelduur & $\begin{array}{c}\text { Plattelandspatiënt } \\
\%\end{array}$ & $\begin{array}{c}\text { Stadspatiènt } \\
\%\end{array}$ & $\begin{array}{c}\text { Totaall } \\
\%\end{array}$ \\
\hline 0 & 11 & 10 & 10 \\
1 & 33 & 40 & 36 \\
2 & 30 & 31 & 30 \\
3 & 26 & 20 & 24 \\
\hline Totaal & $100(\mathrm{~N}=757)$ & $100(\mathrm{~N}=582)$ & $100(\mathrm{~N}=1339)$ \\
\hline
\end{tabular}

Kendall's Tau $C=-0,06 \quad P<0,1$

Tabel 4.2.5.3. Verband tussen uitstelduur en ,stads-plattelandspatiènt" bij oudere patienten in de populatie.

\begin{tabular}{cccc}
\hline & $\begin{array}{c}\text { Plattelandspatiënt } \\
\text { Uitstelduur }\end{array}$ & $\begin{array}{c}\text { Stadspatiënt } \\
\%\end{array}$ & $\begin{array}{c}\text { Totaal } \\
\%\end{array}$ \\
\hline 0 & 7 & 8 & 7 \\
1 & 30 & 38 & 34 \\
2 & 31 & 27 & 29 \\
3 & 33 & 27 & 30 \\
\hline Totaal & $100(\mathrm{~N}=348)$ & $100(\mathrm{~N}=344)$ & $100(\mathrm{~N}=692)$ \\
\hline
\end{tabular}

Kendall's Tau $\mathrm{C}=-0,10 \quad \mathbb{P}<0,1$

Tabel 4.2.5.4. Verband tussen uitstelduur en ,stads-plattelandspatiënt' bij wrouwen in de populatie.

\begin{tabular}{cccc}
\hline Uitstelduur & $\begin{array}{c}\text { Plattelandspatiënt } \\
\%\end{array}$ & $\begin{array}{c}\text { Stadspatiënt } \\
\%\end{array}$ & $\begin{array}{c}\text { Totaal } \\
\%\end{array}$ \\
\hline 0 & 7 & 8 & 7 \\
1 & 27 & 36 & 31 \\
2 & 34 & 28 & 31 \\
3 & 33 & 28 & 31 \\
\hline Totaal & $100(\mathrm{~N}=629)$ & $100(\mathrm{~N}=530)$ & $100(\mathrm{~N}=1159)$ \\
\hline Kendall's Tau $\mathrm{C}=-0,09$ & $\mathrm{P}<0,01$
\end{tabular}


BULAGE II

Tabel 4.2.5.5. Verband tussen uitstelduur en ,stads-plattelandspatiënt" bij patienten in de populatie met lagere opleidingen.

\begin{tabular}{cccc}
\hline Uitstelduur & $\begin{array}{c}\text { Plattelandspatiént } \\
\%\end{array}$ & $\begin{array}{c}\text { Stadspatiënt } \\
\%\end{array}$ & $\begin{array}{c}\text { Totaal } \\
\%\end{array}$ \\
\hline 0 & 10 & 9 & 10 \\
1 & 32 & 42 & 37 \\
2 & 31 & 28 & 30 \\
3 & 27 & 21 & 25 \\
\hline Totaal & $100(\mathrm{~N}=708)$ & $100(\mathrm{~N}=578)$ & $100(\mathrm{~N}=1286)$ \\
\hline
\end{tabular}

Kendall's Tau $\mathrm{C}=-0,08 \quad \mathrm{P}<0,01$

Tabel 4.2.5.6. Verband tussen uitstelduur en ,stads-plattelandspatiënt' bij patiènten in do populatie met k.n.o.-klachten.

\begin{tabular}{cccc}
\hline Uitsteldtur & $\begin{array}{c}\text { Plattelandspatiént } \\
\%\end{array}$ & $\begin{array}{c}\text { Stadspatiënt } \\
\%\end{array}$ & $\begin{array}{c}\text { Totaal } \\
\%\end{array}$ \\
\hline 0 & 12 & 9 & 11 \\
1 & 48 & 61 & 55 \\
2 & 27 & 21 & 24 \\
3 & 13 & 9 & 11 \\
\hline Totaal & $100(\mathrm{~N}=205)$ & $100(\mathrm{~N}=203)$ & $100(\mathrm{~N}=408)$ \\
\hline
\end{tabular}

Kendall's Tau $\mathrm{C}=-0,08 \quad \mathrm{P}<0,1$

Tabel 4.2.5.7. Verband fussen uitstelduur en ,stads-plattelandspatiènt" bij patiënten in de populatie met hartklachten.

\begin{tabular}{lccc}
\hline Uitstelduur & $\begin{array}{c}\text { Plattelandspatiènt } \\
\%\end{array}$ & $\begin{array}{c}\text { Stadspatiënt } \\
\%\end{array}$ & $\begin{array}{c}\text { Totaal } \\
\%\end{array}$ \\
\hline 0 & 8 & 15 & 11 \\
1 & 18 & 27 & 22 \\
2 & 27 & 20 & 24 \\
3 & 47 & 37 & 42 \\
\hline Totaal & $100(\mathrm{~N}=66)$ & $100(\mathrm{~N}=59)$ & $100(\mathrm{~N}<125)$ \\
\hline Kendall's Tau $\mathrm{C}=-0,17$ & $\mathrm{P}<0,1$ &
\end{tabular}


Tabel 4.2.5.8. Verband tussen uitstelduur en stads-plattelandspatiënt' bij patiènten in de populatie met urogenitaalklachten.

\begin{tabular}{cccc}
\hline Uitstelduur & $\begin{array}{c}\text { Plattelandspatiënt } \\
\%\end{array}$ & $\begin{array}{c}\text { Stadspatiënt } \\
\%\end{array}$ & $\begin{array}{c}\text { Totaal } \\
\%\end{array}$ \\
\hline 0 & 8 & 12 & 10 \\
1 & 31 & 38 & 35 \\
2 & 19 & 14 & 16 \\
3 & 43 & 36 & 39 \\
\hline Totaal & $100(\mathrm{~N}=65)$ & $100(\mathrm{~N}=81)$ & $100(\mathrm{~N}=146)$ \\
\hline
\end{tabular}

Kendall's Tau $\mathrm{C}=-0,12 \quad \mathrm{P}<0,1$

Tabel 4.2.5.9. Verband tussen witstelduur on ,stads-plattelandspatiënt" bij patiênten in de populatie met klachten op sexualiteitsgebied.

\begin{tabular}{cccc}
\hline Uitstelduur & $\begin{array}{c}\text { Plattelandspatiënt } \\
\%\end{array}$ & $\begin{array}{c}\text { Stadspatiënt } \\
\%\end{array}$ & $\begin{array}{c}\text { Totaal } \\
\%\end{array}$ \\
\hline 0 & 4 & 5 & 4 \\
1 & 6 & 25 & 14 \\
2 & 24 & 25 & 25 \\
3 & 67 & 46 & 57 \\
\hline Totaal & $100(\mathrm{~N}=54)$ & $100(\mathrm{~N}=44)$ & $100(\mathrm{~N}=98)$ \\
\hline
\end{tabular}

Kendall's Tau $\mathrm{C}=-0,25 \quad \mathrm{P}<0,01$

Tabel 4.2.6.1. Verband tussen uitstelduur en ,ervaring met de klacht' bij patiënten in de populatie met minder ernstige klachten.

\begin{tabular}{cccc}
\hline Uitstelduur & $\begin{array}{c}\text { Geen ervaring } \\
\%\end{array}$ & $\begin{array}{c}\text { Wel ervaring } \\
\%\end{array}$ & $\begin{array}{c}\text { Total } \\
\%\end{array}$ \\
\hline 0 & 11 & 8 & 9 \\
1 & 40 & 38 & 39 \\
2 & 31 & 25 & 27 \\
3 & 18 & 29 & 25 \\
\hline Totaal & $100(\mathrm{~N}=349)$ & $100(\mathrm{~N}=519)$ & $100(\mathrm{~N}=868)$ \\
\hline
\end{tabular}

Kendall's Tau $\mathrm{C}=0,10 \quad \mathrm{P}<0,01$ 
Tabel 4.2.6.2. Verband tussen uitstelduur en ,erwaring met de klacht" bij patiènten in de populatie met de minst ernstige klachten.

\begin{tabular}{cccc}
\hline Uitstelduur & $\begin{array}{c}\text { Geen ervaring } \\
\%\end{array}$ & $\begin{array}{c}\text { Wel ervaring } \\
\%\end{array}$ & $\begin{array}{c}\text { Totaal } \\
\%\end{array}$ \\
\hline 0 & 7 & 3 & 5 \\
1 & 27 & 29 & 28 \\
2 & 40 & 28 & 34 \\
3 & 26 & 40 & 33 \\
\hline Totaal & $100(\mathrm{~N}=243)$ & $100(\mathrm{~N}=251)$ & $100(\mathrm{~N}=494)$ \\
\hline
\end{tabular}

Kendall's Tau $\mathrm{C}=0,13 \quad \mathrm{P}<0,01$

Tabel 4.2.6.3. Verband tussen uitstelduur en „ervaring met de klacht' bij jongere patiënten in de populatie met de minst ernstige klachten.

\begin{tabular}{cccc}
\hline Uitstelduur & $\begin{array}{c}\text { Geen ervaring } \\
\%\end{array}$ & $\begin{array}{c}\text { Well ervaring } \\
\%\end{array}$ & $\begin{array}{c}\text { Totaal } \\
\%\end{array}$ \\
\hline 0 & 7 & 4 & 6 \\
1 & 29 & 30 & 29 \\
2 & 37 & 30 & 34 \\
3 & 27 & 36 & 31 \\
\hline Totaal & $100(\mathbb{N}=192)$ & $100(\mathbb{N}=\mathbb{1 4 8})$ & $100(\mathrm{~N}=340)$ \\
\hline
\end{tabular}

Kendall's Tau $\mathrm{C}=0,09 \quad \mathrm{P}<0,1$

Tabel 4.2.6.4. Verband tussen uitstelduur en ,ervaring met de klacht" bij oudere patiënten in de populativ met minder ernstige klachten.

\begin{tabular}{cccc}
\hline Uitstelluur & $\begin{array}{c}\text { Geen ervaring } \\
\%\end{array}$ & $\begin{array}{c}\text { Wel ervaring } \\
\%\end{array}$ & $\begin{array}{c}\text { Totaal } \\
\%\end{array}$ \\
\hline 0 & 11 & 4 & 6 \\
1 & 42 & 37 & 39 \\
2 & 33 & 23 & 26 \\
3 & 14 & 36 & 29 \\
\hline Totaal & $100(\mathrm{~N}=100)$ & $100(\mathrm{~N}=186)$ & $100(\mathrm{~N}=286)$ \\
\hline Kendall's Tau $\mathrm{C}=0,21$ & $\mathrm{P}<0,001$ &
\end{tabular}


Tabel 4.2.6.5. Verband tussen uitstelduur en ,ervaring met de kiacht bij oudere patiènten in de populatie met de minst ernstige kllachten.

\begin{tabular}{cccc}
\hline Uitstelduur & $\begin{array}{c}\text { Geen ervaring } \\
\%\end{array}$ & $\begin{array}{c}\text { Wel ervaring } \\
\%\end{array}$ & $\begin{array}{c}\text { Totaal } \\
\%\end{array}$ \\
\hline 0 & 4 & 1 & 2 \\
1 & 21 & 29 & 26 \\
2 & 54 & 25 & 35 \\
3 & 21 & 45 & 37 \\
\hline Totaal & $100(\mathrm{~N}=48)$ & $100(\mathrm{~N}=100)$ & $100(\mathrm{~N}=148)$ \\
\hline
\end{tabular}

Kendall's Tau $C=0,13 \quad$ P $<0,1$

Tabel 4.2.6.6. Verband tussen uitstelduur en ,ervaring met de klacht' bij vrouwen in de populatie met minder ernstige klachten.

\begin{tabular}{cccc}
\hline Uitstelduur & $\begin{array}{c}\text { Geen ervaring } \\
\%\end{array}$ & $\begin{array}{c}\text { Wel ervaring } \\
\%\end{array}$ & $\begin{array}{c}\text { Totaal } \\
\%\end{array}$ \\
\hline 0 & 6 & 8 & 7 \\
1 & 37 & 33 & 35 \\
2 & 34 & 25 & 29 \\
3 & 23 & 34 & 29 \\
\hline Totaal & $100(\mathrm{~N}=200)$ & $100(\mathrm{~N}=274)$ & $100(\mathrm{~N}=474)$ \\
\hline
\end{tabular}

Kendall's Tau $C=0,07 \quad P<0,1$

Tabel 4.2.6.7. Verband tussen uitstelduur en ,ervaring met de klacht' bij mannen in de populatie met minder ernstige klachten.

\begin{tabular}{cccc}
\hline Uitstelduur & $\begin{array}{c}\text { Geen ervaring } \\
\%\end{array}$ & $\begin{array}{c}\text { Wel ervaring } \\
\%\end{array}$ & $\begin{array}{c}\text { Totaal } \\
\%\end{array}$ \\
\hline 0 & 18 & 8 & 11 \\
1 & 44 & 44 & 44 \\
2 & 27 & 25 & 26 \\
3 & 11 & 23 & 19 \\
\hline Totaal & $100(\mathrm{~N}=\mathbb{1 4} 1)$ & $100(\mathrm{~N}=241)$ & $100(\mathrm{~N}=382)$ \\
\hline
\end{tabular}

Kendall's Tau $\mathrm{C}=0,16 \quad \mathrm{P}<0,01$ 
Tabel 4.2.6.8. Verband tussen uitstelduur en ,ervaring met de klacht bij mannen in de populatie met de minst erristige klachten.

\begin{tabular}{cccc}
\hline Uitstelduur & $\begin{array}{c}\text { Geen ervaring } \\
\%\end{array}$ & $\begin{array}{c}\text { Wel ervaring } \\
\%\end{array}$ & $\begin{array}{c}\text { Totaal } \\
\%\end{array}$ \\
\hline 0 & 11 & 2 & 7 \\
1 & 35 & 35 & 35 \\
2 & 40 & 26 & 33 \\
3 & 14 & 37 & 25 \\
\hline Totaal & $100(\mathrm{~N}=91)$ & $100(\mathrm{~N}=81)$ & $100(\mathrm{~N}=172)$ \\
\hline
\end{tabular}

Kendall's Tau $C=0,23 \quad P<0,01$

Tabel 4.2.6.9. Verband tussen uitstelduur en ,ervaring met de klacht' bij patiënten in de populatie met een lagere opleidling met de meest ernstige klachten.

\begin{tabular}{cccc}
\hline Uitstelduur & $\begin{array}{c}\text { Geen ervaring } \\
\%\end{array}$ & $\begin{array}{c}\text { Wel ervaring } \\
\%\end{array}$ & $\begin{array}{c}\text { Total } \\
\%\end{array}$ \\
\hline 0 & 17 & 13 & 15 \\
1 & 37 & 35 & 36 \\
2 & 30 & 28 & 29 \\
3 & 16 & 24 & 20 \\
\hline Totaal & $100(\mathrm{~N}=154)$ & $100(\mathrm{~N}=123)$ & $100(\mathrm{~N}=277)$ \\
\hline Kendall's Tau $\mathrm{C}=0,09$ & $\mathrm{P}<0,1$ &
\end{tabular}

Tabel 4.2,6.10. Verband tussen uitstelduur en ,ervaring met de klacht' bij patiënten in de populatie met een lagere opleiding met minder ernstige klachten.

\begin{tabular}{cccc}
\hline Uitsteldur & $\begin{array}{c}\text { Geen ervaring } \\
\%\end{array}$ & $\begin{array}{c}\text { Wel ervaring } \\
\%\end{array}$ & $\begin{array}{c}\text { Totaal } \\
\%\end{array}$ \\
\hline 0 & 12 & 6 & 8 \\
1 & 42 & 42 & 42 \\
2 & 30 & 24 & 26 \\
3 & 16 & 28 & 24 \\
\hline Totaal & $100(\mathrm{~N}=203)$ & $100(\mathrm{~N}=333)$ & $100(\mathrm{~N}=536)$ \\
\hline
\end{tabular}

Kendall's Tau $\mathrm{C}=0,12 \quad \mathrm{P}<0,01$ 
Tabel 4.2.6.11. Verband tussen vitstelduw en ,ervaring met de klacht bij patienten in de populatie met een midden opleiding met de minst ernstige klachten.

\begin{tabular}{cccc}
\hline Uitstelduur & $\begin{array}{c}\text { Geen ervaring } \\
\%\end{array}$ & $\begin{array}{c}\text { Wel ervaring } \\
\%\end{array}$ & $\begin{array}{c}\text { Total } \\
\%\end{array}$ \\
\hline 0 & 11 & 3 & 7 \\
1 & 27 & 25 & 26 \\
2 & 42 & 26 & 34 \\
3 & 20 & 46 & 33 \\
\hline Totaal & $100(\mathbf{N}=70)$ & $100(\mathbf{N}=68)$ & $100(\mathbf{N}=138)$ \\
\hline Kendall's Tan $\mathrm{C}=0,26$ & $\mathbf{P}<0,01$
\end{tabular}

Tabel 4.2.6.12. Verband tussen uitstelduur en ,ervaring met de klacht' bij patienten in de populatie met een hogere opleiding met minder ernstige klachten.

\begin{tabular}{cccc}
\hline Uitstelduur & $\begin{array}{c}\text { Geen ervaring } \\
\%\end{array}$ & $\begin{array}{c}\text { Wel ervaring } \\
\%\end{array}$ & $\begin{array}{c}\text { Totaal } \\
\%\end{array}$ \\
\hline 0 & 13 & 17 & 15 \\
1 & 34 & 15 & 23 \\
2 & 31 & 30 & 30 \\
3 & 22 & 38 & 32 \\
\hline Totaall & $100(\mathrm{~N}=32)$ & $100(\mathbf{N}=47)$ & $100(\mathbf{N}=79)$ \\
\hline Kendall's Tau $\mathrm{C}=0,16$ & $\mathbf{P}<0,1$ & &
\end{tabular}

Tabel 4.2.6.13. Verband tussen uitstelduur en, erwaring met de klacht bij patienten in de populatie met een hogere opleiding met de minst ernstige klachten.

\begin{tabular}{cccc}
\hline Uitstelduur & $\begin{array}{c}\text { Geen ervaring } \\
\%\end{array}$ & $\begin{array}{c}\text { Wel ervaring } \\
\%\end{array}$ & $\begin{array}{c}\text { Total } \\
\%\end{array}$ \\
\hline 0 & 0 & 4 & 2 \\
1 & 35 & 12 & 24 \\
2 & 38 & 28 & 33 \\
3 & 27 & 56 & 41 \\
\hline Totaal & $100(\mathrm{~N}=26)$ & $100(\mathrm{~N}=25)$ & $100(\mathrm{~N}=51)$ \\
\hline
\end{tabular}

Kendall's Tau $\mathrm{C}=0,31 \quad \mathrm{P}<0,1$ 
Tabel 4.3.1.1. Verband tussen uitstelduur en ,ernst van de klacht bij patiënten in de populatie.

\begin{tabular}{ccccc}
\hline $\begin{array}{c}11 \text { meest } \\
\text { ernstige } \\
\text { klachten } \\
\%\end{array}$ & $\begin{array}{c}18 \text { minder } \\
\text { ernstige } \\
\text { klachten } \\
\%\end{array}$ & $\begin{array}{c}11 \text { minst } \\
\text { ernstige } \\
\text { klachten } \\
\%\end{array}$ & Totaal \\
\hline 0 & 13 & 9 & 5 & $\%$ \\
1 & 36 & 39 & 28 & 9 \\
2 & 29 & 27 & 34 & 35 \\
3 & 22 & 25 & 33 & 30 \\
Totaal & $100(\mathrm{~N}=453)$ & $100(\mathrm{~N}=865)$ & $100(\mathrm{~N}=494)$ & $100(\mathrm{~N}=1812)$ \\
\hline
\end{tabular}

Kendall's Tau $\mathrm{C}=0,12 \quad \mathrm{P}<0,001$

Tabel 4.3.1.2. Verband tussen uitstelduur en ,ernst van de klacht' bij jongere patiënten in de populatie.

\begin{tabular}{ccccc}
\hline Uitstelduur & $\begin{array}{c}11 \text { meest } \\
\text { ernstige } \\
\text { klachten }\end{array}$ & $\begin{array}{c}18 \text { minder } \\
\text { ernstige } \\
\text { klachten } \\
\%\end{array}$ & $\begin{array}{c}11 \text { minst } \\
\text { ernstige } \\
\text { klachten } \\
\%\end{array}$ & Totaal \\
\hline 0 & 14 & 10 & 6 & $\%$ \\
1 & 38 & 39 & 29 & 10 \\
2 & 29 & 28 & 34 & 36 \\
3 & 19 & 23 & 31 & 30 \\
Totaal & $100(\mathrm{~N}=257)$ & $100(\mathrm{~N}=567)$ & $100(\mathrm{~N}=340)$ & $100(\mathrm{~N}=1164)$ \\
\hline
\end{tabular}

Kendall's Tau $\mathrm{C}=0,13 \quad \mathrm{P}<0,001$

Tabel 4.3.1.3. Verband tussen uitstelduur en ,ernst van de klacht' bij oudere patiënten in de populatio.

\begin{tabular}{ccccc}
\hline Uitstelduur & $\begin{array}{c}11 \text { meesit } \\
\text { ernstige } \\
\text { klachten } \\
\%\end{array}$ & $\begin{array}{c}18 \text { minder } \\
\text { ernstige } \\
\text { klachten } \\
\%\end{array}$ & $\begin{array}{c}11 \text { minst } \\
\text { ernstige } \\
\text { klachten } \\
\%\end{array}$ & Totaal \\
\hline 0 & 11 & 6 & 2 & $\%$ \\
1 & 33 & 39 & 26 & 7 \\
2 & 30 & 26 & 35 & 34 \\
3 & 26 & 29 & 37 & 30 \\
\hline Totaal & $100(\mathrm{~N}=192)$ & $100(\mathrm{~N}=286)$ & $100(\mathrm{~N}=148)$ & $100(\mathrm{~N}=626)$ \\
\hline
\end{tabular}

Kendall's Tau $\mathrm{C}=0,11 \quad \mathrm{P}<0,01$ 
Tabel 4.3.1.4. Verband tussen uitstelduur en ,ernst van de klacht" bij mannen in de populatie.

\begin{tabular}{ccccc}
\hline & $\begin{array}{c}11 \text { meest } \\
\text { ernstige } \\
\text { klachten } \\
\text { Uitstelduur }\end{array}$ & $\begin{array}{c}18 \text { minder } \\
\text { ernstige } \\
\text { klachten } \\
\%\end{array}$ & $\begin{array}{c}11 \text { minst } \\
\text { ernstige } \\
\text { klachten } \\
\%\end{array}$ & Totaal \\
\hline 0 & 16 & 11 & 7 & $\%$ \\
1 & 37 & 44 & 35 & 12 \\
2 & 27 & 26 & 33 & 40 \\
3 & 20 & 19 & 25 & 28 \\
\hline Totaal & $100(\mathrm{~N}=217)$ & $100(\mathrm{~N}=382)$ & $100(\mathrm{~N}=172)$ & $100(\mathrm{~N}=771)$ \\
\hline
\end{tabular}

Kendall's Tau $C=0,07 \quad P<0,01$

Tabel 4.3.1.5. Verband tussen uitstelduur en ,ernst van de klacht" bij vrouwen in de populatie.

\begin{tabular}{|c|c|c|c|c|}
\hline & $\begin{array}{l}11 \text { meest } \\
\text { ernstige } \\
\text { klachten }\end{array}$ & $\begin{array}{l}18 \text { minder } \\
\text { ernstige } \\
\text { klachten }\end{array}$ & $\begin{array}{l}11 \text { minst } \\
\text { ernstige } \\
\text { klachten }\end{array}$ & Totaal \\
\hline Uitstelduur & $\%$ & $\%$ & $\%$ & $\%$ \\
\hline 0 & 11 & 7 & 4 & 7 \\
\hline 1 & 35 & 35 & 24 & 31 \\
\hline 2 & 29 & 29 & 35 & 31 \\
\hline 3 & 25 & 29 & 37 & 31 \\
\hline Totaal & $100(\mathrm{~N}=230)$ & $100(N=474)$ & $100(\mathrm{~N}=315)$ & $100(\mathbb{N}=1019)$ \\
\hline
\end{tabular}

Kendall's Tau $C=0,13 \quad P<0,001$

Tabel 43.1.6. Verband tussen uitstelduur en ,ermst van de klacht" bij patiënten met een ,lagere opleiding" in de populatie.

\begin{tabular}{ccccc}
\hline & $\begin{array}{c}11 \text { meest } \\
\text { rnstige } \\
\text { klachten } \\
\text { Uitstelduur }\end{array}$ & $\begin{array}{c}18 \text { minder } \\
\text { ernstige } \\
\text { klachten } \\
\%\end{array}$ & $\begin{array}{c}11 \text { minst } \\
\text { entistige } \\
\text { klachten } \\
\%\end{array}$ & Totaal \\
\hline 0 & 15 & 8 & 4 & $\%$ \\
1 & 36 & 42 & 30 & 9 \\
2 & 29 & 26 & 34 & 29 \\
3 & 20 & 24 & 32 & 25 \\
\hline Totaal & $100(\mathrm{~N}=277)$ & $100(\mathrm{~N}=536)$ & $100(\mathrm{~N}=303)$ & $100(\mathrm{~N}=1116)$ \\
\hline
\end{tabular}

Kendall's Tau $C=0,13 \quad P<0,001$ 
Tabel 4.3.1.7. Verband tussen uitstelduur en ,ernst van de klacht" bij patiënten met een ,midden opleiding in de populatie.

\begin{tabular}{ccccc}
\hline & $\begin{array}{c}11 \text { meest } \\
\text { ernstige } \\
\text { klachten } \\
\%\end{array}$ & $\begin{array}{c}18 \text { minder } \\
\text { ernstige } \\
\text { klachten } \\
\%\end{array}$ & $\begin{array}{c}11 \text { minst } \\
\text { ernstige } \\
\text { klachten } \\
\%\end{array}$ & Totaal \\
\hline 0 & 10 & 8 & 7 & $\%$ \\
1 & 36 & 39 & 26 & 34 \\
2 & 32 & 29 & 34 & 31 \\
3 & 22 & 24 & 33 & 26 \\
\hline Totaal & $100(\mathrm{~N}=132)$ & $100(\mathrm{~N}=244)$ & $100(\mathrm{~N}=138)$ & $100(\mathrm{~N}=514)$ \\
\hline
\end{tabular}

Kendall's Tau $\mathrm{C}=0,09 \quad \mathrm{P}<0,01$

Tabel 4.3.2.1. Verband tussen uitstelduur en klachtenpatronen mèt en zònder pijn van patiênten in de populatie.

\begin{tabular}{lccc}
\hline & $\begin{array}{c}\text { Klachten } \\
\text { met pijn } \\
\%\end{array}$ & $\begin{array}{c}\text { Klachten } \\
\text { zonder pijn } \\
\%\end{array}$ & $\begin{array}{c}\text { Totaal } \\
\%\end{array}$ \\
Uitstelduur & 16 & 7 & 9 \\
\hline 0 & 45 & 31 & 35 \\
1 & 23 & 33 & 30 \\
2 & 16 & 29 & 26 \\
3 & $100(\mathrm{~N}=552)$ & $100(\mathrm{~N}=1503)$ & $100(\mathrm{~N}=2055)$ \\
\hline Totaal & $\mathrm{P}<0,001$ &
\end{tabular}

Tabell 4.3.2.2. Verband tussen uitstelduur en klachtenpatronen mèt en zònder pijn van jongere patiënten in de populatie.

\begin{tabular}{cccc}
\hline & $\begin{array}{c}\text { Klachten } \\
\text { met pijn } \\
\%\end{array}$ & $\begin{array}{c}\text { Klachten } \\
\text { zonder pijin } \\
\%\end{array}$ & $\begin{array}{c}\text { Totaal } \\
\%\end{array}$ \\
\hline Uitstelduur & 16 & 8 & 10 \\
1 & 47 & 31 & 36 \\
2 & 23 & 34 & 30 \\
3 & 14 & 27 & 24 \\
\hline Totaal & $100(\mathrm{~N}=377)$ & $100(\mathrm{~N}=962)$ & $100(\mathrm{~N}=1339)$ \\
\hline
\end{tabular}

Kendall's Tau $\mathrm{C}=0,22 \quad \mathbf{P}<0,001$ 
Tabel 4.3.2.3. Verband tussen uitstelduur en kachtenpatronen mèt en zònder pijn van oudere patiënten in de populatie.

\begin{tabular}{cccc}
\hline Kiachten & $\begin{array}{c}\text { Klachten } \\
\text { met pijn } \\
\%\end{array}$ & $\begin{array}{c}\text { zonder pijn } \\
\%\end{array}$ & $\begin{array}{c}\text { Total } \\
\%\end{array}$ \\
\hline 0 & 13 & 5 & 7 \\
1 & 41 & 32 & 34 \\
2 & 24 & 31 & 29 \\
3 & 22 & 32 & 30 \\
\hline Totaal & $100(\mathrm{~N}=167)$ & $100(\mathrm{~N}=525)$ & $100(\mathrm{~N}=692)$ \\
\hline
\end{tabular}

Kendall's Tau $\mathrm{C}=0,15 \quad \mathrm{P}<0,001$

Tabel 4.3.2.4. Verband tussen uitstelduur en klachtenpatronen mèt ên zònder pijn van mannen in de populatie.

\begin{tabular}{cccc}
\hline & $\begin{array}{c}\text { Klachten } \\
\text { met pijn } \\
\%\end{array}$ & $\begin{array}{c}\text { Klachiten } \\
\text { zonder pijn } \\
\text { Uitsteldure }\end{array}$ & $\begin{array}{c}\text { Total } \\
\%\end{array}$ \\
\hline 0 & 20 & 9 & 12 \\
1 & 46 & 37 & 40 \\
2 & 20 & 32 & 28 \\
3 & 14 & 22 & 20 \\
\hline Totaal & $100(\mathrm{~N}=260)$ & $100(\mathrm{~N}=610)$ & $100(\mathrm{~N}=870)$ \\
\hline
\end{tabular}

Kendall's Tau $C=0,18 \quad P<0,001$

Tabel 4.3.2.5. Verband tussen uitstelduur en klachtenpatronen mèt en zònder pijn wan vrouwen in de populatie.

\begin{tabular}{cccc}
\hline & $\begin{array}{l}\text { Klachten } \\
\text { met piji } \\
\text { Uitsteldutr }\end{array}$ & $\begin{array}{c}\text { Klachtion } \\
\text { zonder pijn } \\
\%\end{array}$ & $\begin{array}{c}\text { Totaal } \\
\%\end{array}$ \\
\hline 0 & 13 & 5 & 7 \\
1 & 45 & 27 & 31 \\
2 & 24 & 33 & 31 \\
3 & 18 & 35 & 31 \\
\hline Totaal & $100(\mathrm{~N}=281)$ & $100(\mathrm{~N}=878)$ & $100(\mathrm{~N}=1159)$ \\
\hline Kendall"s Tau $\mathrm{C}=0,21$ & $\mathrm{P}<0,001$ &
\end{tabular}


WULAGE II

Tabel 4.3.2.6. Verband tussen uitstelduur en klachtenpatronen mèt en zònder pijn yan patienten in de populatie met "lagere opleidingen".

\begin{tabular}{cccc}
\hline Uitstefduur & $\begin{array}{c}\text { Klachten } \\
\text { met pijn } \\
\%\end{array}$ & $\begin{array}{c}\text { Klachten } \\
\text { zonder pijn } \\
\%\end{array}$ & $\begin{array}{c}\text { Totaal } \\
\%\end{array}$ \\
\hline 0 & 16 & 7 & 9 \\
1 & 44 & 34 & 37 \\
2 & 24 & 31 & 30 \\
3 & 16 & 28 & 24 \\
\hline Totaal & $100(\mathrm{~N}=361)$ & $100(\mathrm{~N}=925)$ & $100(\mathrm{~N}=1286)$ \\
\hline
\end{tabular}

Kendall's Tau $\mathrm{C}=0,19 \quad \mathrm{P}<0,001$

Tabel 4.3.2.7. Verband tussen uitstelduur en klachtenpatronen mèt en zònder pijn van patiënten in de populatie met, midden opleidingen'.

\begin{tabular}{lccc}
\hline & $\begin{array}{c}\text { Klachten } \\
\text { met pijn } \\
\%\end{array}$ & $\begin{array}{c}\text { Klachten } \\
\text { zonder pijn } \\
\%\end{array}$ & $\begin{array}{c}\text { Totaal } \\
\%\end{array}$ \\
Uitstelduur & 16 & 7 & 9 \\
\hline 0 & 51 & 29 & 34 \\
1 & 20 & 34 & 31 \\
2 & 13 & 30 & 26 \\
3 & $100(\mathrm{~N}=142)$ & $100(\mathrm{~N}=431)$ & $100(\mathrm{~N}=573)$ \\
\hline Totaal & $\mathrm{P}<0,001$ &
\end{tabular}

Tabel 4.3.2.8. Verband tussen uitstelduur en klachtenpatronen mèt en zònder pijn van patiënten in de populatio met ,hogere opleidingen'.

\begin{tabular}{cccc}
\hline & $\begin{array}{c}\text { Klachten } \\
\text { met pijn } \\
\%\end{array}$ & $\begin{array}{c}\text { Klachiten } \\
\text { zonder pijn } \\
\%\end{array}$ & $\begin{array}{c}\text { Totaal } \\
\%\end{array}$ \\
\hline 0 & 20 & 7 & 10 \\
1 & 39 & 23 & 27 \\
2 & 15 & 33 & 29 \\
3 & 26 & 37 & 34 \\
\hline Totaal & $100(\mathrm{~N}=46)$ & $100(\mathrm{~N}=136)$ & $100(\mathrm{~N}=182)$ \\
\hline Kendall's Tau $\mathrm{C}=0,21$ & $\mathrm{P}<0,01$ & &
\end{tabular}


Tabel 4.3.2.9. Verband tussen uitstelduur en klachtenpatronen mèt en zônder pijn van patiënten in de populatie met algemene klachten.

\begin{tabular}{lccc}
\hline & $\begin{array}{c}\text { Klachten } \\
\text { met pijn } \\
\%\end{array}$ & $\begin{array}{c}\text { Klachten } \\
\text { zonder pijn } \\
\%\end{array}$ & $\begin{array}{c}\text { Totaal } \\
\%\end{array}$ \\
Uitstelduur & 23 & 4 & 8 \\
0 & 42 & 22 & 25 \\
1 & 22 & 43 & 39 \\
2 & 13 & 31 & 28 \\
\hline 3 & $100 \quad \mathrm{~N}=78)$ & $100(\mathrm{~N}=344)$ & $100(\mathrm{~N}=422)$ \\
\hline Totaal & $\mathbf{P}<0,001$ &
\end{tabular}

Tabel 4.3.2.10. Verband tussen uitstelduur en klachtenpatronen mèt en zònder pijn van patiënten in de populatie met k.n.o.-klachten.

\begin{tabular}{cccc}
\hline & $\begin{array}{c}\text { Klachten } \\
\text { met pijn } \\
\%\end{array}$ & $\begin{array}{c}\text { Klachten } \\
\text { zonder pijin } \\
\%\end{array}$ & $\begin{array}{c}\text { Totaal } \\
\%\end{array}$ \\
Uitstelduur & 20 & 10 & 14 \\
0 & 63 & 54 & 57 \\
1 & 12 & 25 & 20 \\
2 & 5 & 11 & 9 \\
3 & $100(\mathrm{~N}=76)$ & $100(\mathrm{~N}=143)$ & $100(\mathrm{~N}=219)$ \\
\hline Totaal & $\mathrm{P}<0,01$ & &
\end{tabular}

Tabel 4.3.2.11. Verband tussen uitstelduur en klachtenpatronen mèt en zònder pijn van patiënten in de populatie met hartklachten.

\begin{tabular}{cccc}
\hline & $\begin{array}{c}\text { Klachten } \\
\text { met pijn } \\
\text { Uitstelduur }\end{array}$ & $\begin{array}{c}\text { Klachiten } \\
\text { zonder pijn } \\
\%\end{array}$ & $\begin{array}{c}\text { Totaal } \\
\%\end{array}$ \\
\hline 0 & 33 & 8 & 11 \\
1 & 17 & 23 & 23 \\
2 & 22 & 24 & 24 \\
3 & 28 & 45 & 42 \\
\hline Totaal & $100(\mathrm{~N}=18)$ & $100(\mathrm{~N}=107)$ & $100(\mathrm{~N}=125)$ \\
\hline
\end{tabular}

Kendall's Tau $\mathrm{C}=0,14 \quad \mathrm{P}<0,1$ 
Tabel 4.3.2.12. Verband tussen uitstelduur en klachtenpatronen mèt en zònder pijn van patiernten in de populatie met urogenitaaklachten.

\begin{tabular}{cccc}
\hline & $\begin{array}{c}\text { Klachten } \\
\text { met pijn } \\
\%\end{array}$ & $\begin{array}{c}\text { Klachten } \\
\text { zonder pijn } \\
\%\end{array}$ & $\begin{array}{c}\text { Totaal } \\
\%\end{array}$ \\
Uitstelduur & 14 & 9 & 10 \\
\hline 0 & 63 & 23 & 35 \\
1 & 7 & 19 & 16 \\
2 & 16 & 49 & 39 \\
3 & $100(\mathbb{N}=43)$ & $100(\mathrm{~N}=103)$ & $100(\mathbb{N}=146)$ \\
\hline Totaal & $\mathrm{P}<0,001$ &
\end{tabular}

Tabei 4.3.2.13. Verband tussen uitstelduur en klachtenpatronen mèt en zònder pijn van patiënten in de populatie met klachtem van het bewegingsapparat.

\begin{tabular}{cccc}
\hline Uitsteldurir & $\begin{array}{c}\text { Klachten } \\
\text { met pijn } \\
\%\end{array}$ & $\begin{array}{c}\text { Klachten } \\
\text { zonder pijn } \\
\%\end{array}$ & $\begin{array}{c}\text { Totaal } \\
\%\end{array}$ \\
\hline 0 & 15 & 6 & 11 \\
1 & 37 & 29 & 33 \\
2 & 29 & 35 & 32 \\
3 & 19 & 30 & 24 \\
\hline Totaal & $100(\mathrm{~N}=231)$ & $100(\mathrm{~N}=189)$ & $100(\mathrm{~N}=420)$ \\
\hline
\end{tabular}

Kendall's Tau $\mathrm{C}=0,20 \quad \mathrm{P}<0,001$

Tabel 4.3.3.1. Verband tussen uitstelduur en ,karakter wan de klacht wat betreft overwegend somatisch of psychisch', bij patienten in de populatie.

\begin{tabular}{cccccc}
\hline Uitsteldutur & $\begin{array}{c}\text { Somatisch } \\
\%\end{array}$ & $\begin{array}{c}\text { Psycho- } \\
\text { somatisch } \\
\%\end{array}$ & $\begin{array}{c}\text { Psychisch } \\
\%\end{array}$ & $\begin{array}{c}\text { Matatschappelijk } \\
\%\end{array}$ & $\begin{array}{c}\text { Total } \\
\%\end{array}$ \\
\hline 0 & 12 & 3 & 5 & 6 & 10 \\
1 & 40 & 22 & 29 & 1.0 & 35 \\
2 & 21 & 30 & 26 & 10 & 23 \\
3 & 27 & 45 & 40 & 74 & 32 \\
\hline Totaal & 100 & 100 & 100 & 100 & 100 \\
& $(\mathbf{N}=1365)$ & $(\mathbf{N}=339)$ & $(\mathbf{N}=238)$ & $(\mathbf{N}=51)$ & $(\mathbf{N}=1993)$ \\
\hline Kendall's Tau $\mathbf{B}=0,20$ & $\mathbf{P}<0,001$ & & &
\end{tabular}


Tabel 4.3.3.2. Verband tussen uitstelduur en ,karakter van de klacht wat betreft overwegend somatisch of psychisch", bij jongere patiënten in de populatie.

\begin{tabular}{cccccc}
\hline Uitstelduur & $\begin{array}{c}\text { Somatisch } \\
\%\end{array}$ & $\begin{array}{c}\text { Psycho- } \\
\text { somatisch } \\
\%\end{array}$ & $\begin{array}{c}\text { Psychisch } \\
\%\end{array}$ & $\begin{array}{c}\text { Maatschappelijk } \\
\%\end{array}$ & $\begin{array}{c}\text { Total } \\
\%\end{array}$ \\
\hline 0 & 13 & 7 & 4 & 7 & 10 \\
1 & 42 & 28 & 22 & 7 & 36 \\
2 & 27 & 36 & 42 & 20 & 30 \\
3 & 18 & 29 & 32 & 66 & 24 \\
\hline Totaal & 100 & 100 & 100 & 100 & 100 \\
& $(\mathrm{~N}=893)$ & $(\mathrm{N}=135)$ & $(\mathrm{N}=227)$ & $(\mathrm{N}=45)$ & $(\mathrm{N}=1300)$ \\
\hline Kendall's Tau $\mathrm{B}=0,24$ & $\mathbf{P}<0,001$ & & &
\end{tabular}

Tabel 4.3.3.3. Verband tussen uitstelduur en ,karakter wan de klacht wat betreft overwegend somatisch of psychisch', bij oudere patiënten in de populatie.

\begin{tabular}{cccccc}
\hline Uitstelduor & $\begin{array}{c}\text { Somatisch } \\
\%\end{array}$ & $\begin{array}{c}\text { Psycho- } \\
\text { somatisch } \\
\%\end{array}$ & $\begin{array}{c}\text { Psychisch } \\
\%\end{array}$ & $\begin{array}{c}\text { Matschappelijk } \\
\%\end{array}$ & $\begin{array}{c}\text { Total } \\
\%\end{array}$ \\
\hline 0 & 9 & 3 & 1 & 0 & 7 \\
1 & 38 & 30 & 23 & 33 & 34 \\
2 & 27 & 28 & 33 & 33 & 28 \\
3 & 26 & 38 & 43 & 34 & 31 \\
\hline Totaal & 100 & 100 & 100 & 100 & 100 \\
& $(\mathrm{~N}=453)$ & $(\mathrm{N}=102)$ & $(\mathrm{N}=108)$ & $(\mathrm{N}=6)$ & $(\mathrm{N}=669)$ \\
\hline
\end{tabular}

Kendall's Tau $\mathrm{B}=0,18 \quad \mathbf{P}<0,001$

Tabel 4.3.3.4. Verband tussen uitstelduur en ,karakter van de klacht wat betreft overwegend somatisch of psychisch', bij mannen in de populatie.

\begin{tabular}{cccccc}
\hline Uitstelduur & $\begin{array}{c}\text { Somatisch } \\
\%\end{array}$ & $\begin{array}{c}\text { Psycho- } \\
\text { somatisch } \\
\%\end{array}$ & $\begin{array}{c}\text { Psychisch } \\
\%\end{array}$ & $\begin{array}{c}\text { Maatschappelijk } \\
\%\end{array}$ & $\begin{array}{c}\text { Totaal } \\
\%\end{array}$ \\
\hline 0 & 15 & 7 & 5 & 0 & 13 \\
1 & 42 & 42 & 29 & 37 & 40 \\
2 & 26 & 21 & 40 & 38 & 28 \\
3 & 17 & 30 & 26 & 25 & 19 \\
\hline Totaal & 100 & 100 & 100 & 100 & 100 \\
& $(\mathrm{~N}=620)$ & $(\mathrm{N}=82)$ & $(\mathrm{N}=130)$ & $(\mathrm{N}=8)$ & $(\mathrm{N}=840)$ \\
\hline Kendall's Tau $\mathrm{B}=0,16$ & $\mathrm{P}<0,001$ & & &
\end{tabular}


Tabel 4.3.3.5. Verband tusisen uitstelduur en, karakter van de klacht wat betreft owerwegend somatisch of psychisch", bij vrouwen in de populatie.

\begin{tabular}{cccccc}
\hline & $\begin{array}{c}\text { Somatisch } \\
\text { Uitstelduur }\end{array}$ & $\begin{array}{c}\text { Psycho- } \\
\text { somatisch } \\
\%\end{array}$ & $\begin{array}{c}\text { Psychisch } \\
\%\end{array}$ & $\begin{array}{c}\text { Maatschappelijk } \\
\%\end{array}$ & $\begin{array}{c}\text { Totaal } \\
\%\end{array}$ \\
\hline 0 & 10 & 4 & 1 & 7 & 7 \\
1 & 38 & 23 & 19 & 5 & 31 \\
2 & 27 & 38 & 39 & 18 & 31 \\
3 & 25 & 35 & 41 & 70 & 31 \\
\hline Total & 100 & 100 & 100 & 100 & 100 \\
& $(\mathrm{~N}=723)$ & $(\mathrm{N}=155)$ & $(\mathrm{N}=207)$ & $(\mathrm{N}=43)$ & $(\mathrm{N}=1128)$ \\
\hline Kendall"s Tau $\mathrm{B}=0,24$ & $\mathbf{P}<0,001$ & & &
\end{tabular}

Tabel 4.3.3.6. Verband tussen uitstelduur en ,karakter van de klacht wat betreft owerwegend somatisch of psychisch', buj patiënten in de populatie met , lagere opleidingen'.

\begin{tabular}{cccccc}
\hline Uitstelduur & $\begin{array}{c}\text { Somatisch } \\
\%\end{array}$ & $\begin{array}{c}\text { Psycho- } \\
\text { somatisch } \\
\%\end{array}$ & $\begin{array}{c}\text { Psychisch } \\
\%\end{array}$ & $\begin{array}{c}\text { Maatschappelijk } \\
\%\end{array}$ & $\begin{array}{c}\text { Totaal } \\
\%\end{array}$ \\
\hline 0 & 12 & 6 & 3 & 7 & 9 \\
1 & 41 & 32 & 24 & 15 & 36 \\
2 & 27 & 30 & 39 & 22 & 29 \\
3 & 20 & 32 & 34 & 56 & 25 \\
\hline Totaal & 100 & 100 & 100 & 100 & 100 \\
& $(\mathrm{~N}=846)$ & $(\mathbb{N}=176)$ & $(\mathbf{N}=200)$ & $(\mathbf{N}=27)$ & $(\mathbf{N}=1249)$ \\
\hline
\end{tabular}

Kendall's Tau $\mathbf{B}=0,20 \quad \mathrm{P}<0,001$

Tabel 4.3.3.7. Verband tussen uitstelduur en ,karakter van de klacht wat betreft overwegend somatisch of psychisch", bij patiënten in de populatie met ,midden opleidingen".

\begin{tabular}{cccccc}
\hline Uitstelduur & $\begin{array}{c}\text { Somatisch } \\
\%\end{array}$ & $\begin{array}{c}\text { Psycho- } \\
\text { somatisch } \\
\%\end{array}$ & $\begin{array}{c}\text { Psychisch } \\
\%\end{array}$ & $\begin{array}{c}\text { Maatschappelijk } \\
\%\end{array}$ & $\begin{array}{c}\text { Total } \\
\%\end{array}$ \\
\hline 0 & 12 & 6 & 4 & 0 & 9 \\
1 & 42 & 25 & 23 & 6 & 35 \\
2 & 27 & 38 & 38 & 12 & 30 \\
3 & 19 & 31 & 35 & 82 & 26 \\
\hline Total & 100 & 100 & 100 & 100 & 100 \\
& $(\mathrm{~N}=373)$ & $(\mathbb{N}=48)$ & $(\mathbf{N}=113)$ & $(\mathrm{N}=17)$ & $(\mathbf{N}=551)$ \\
\hline
\end{tabular}

Kendall's Tau $B=0,26 \quad P<0,001$ 
Tabel 4.3.3.8. Verband tussen vitstelduur en ${ }_{2}$ karakter van de klacht wat betreft overwegend somatisch of psychisch", bij patiènten in de populatie met "hogere opleidingen".

\begin{tabular}{cccccc}
\hline Uitstelduur & $\begin{array}{c}\text { Somatisch } \\
\%\end{array}$ & $\begin{array}{c}\text { Psycho- } \\
\text { somatisch } \\
\%\end{array}$ & $\begin{array}{c}\text { Psychisch } \\
\%\end{array}$ & $\begin{array}{c}\text { Martschappelijk } \\
\%\end{array}$ & $\begin{array}{c}\text { Totaal } \\
\%\end{array}$ \\
\hline 0 & 12 & 0 & 0 & 14 & 10 \\
1 & 35 & 0 & 9 & 0 & 28 \\
2 & 23 & 46 & 48 & 43 & 28 \\
3 & 30 & 54 & 43 & 43 & 34 \\
\hline Total & 100 & 100 & 100 & 100 & 100 \\
& $(\mathbf{N}=137)$ & $(\mathbf{N}=13)$ & $(\mathbf{N}=23)$ & $(\mathbf{N}=7)$ & $(\mathbf{N}=180)$ \\
\hline
\end{tabular}

Kendall's Tau $B=0,24 \quad \mathbb{P}<0,001$

Tabel 4.3.3.9. Verband tussen uitstelduur en ,karakter van de klacht wat betreft overwegend somatisch of psychisch", bij patiênten in de populatie met buikklachten.

\begin{tabular}{cccccc}
\hline Uitstelduur & $\begin{array}{c}\text { Somatisch } \\
\%\end{array}$ & $\begin{array}{c}\text { Psycho- } \\
\text { somatisch } \\
\%\end{array}$ & $\begin{array}{c}\text { Psychisch } \\
\%\end{array}$ & $\begin{array}{c}\text { Maatschappelijk } \\
\%\end{array}$ & $\begin{array}{c}\text { Totaal } \\
\%\end{array}$ \\
\hline 0 & 15 & 11 & 0 & 33 & 11 \\
1 & 47 & 26 & 28 & 33 & 39 \\
2 & 19 & 43 & 34 & 0 & 26 \\
3 & 19 & 20 & 38 & 34 & 34 \\
\hline Totaal & 100 & 100 & 100 & 100 & 100 \\
& $(\mathbf{N}=121)$ & $(\mathbf{N}=35)$ & $(\mathbf{N}=50)$ & $(\mathbf{N}=3)$ & $(\mathbf{N}=209)$ \\
\hline
\end{tabular}

Kendall's Tau $B=0,24 \quad \mathbf{P}<0,001$

Tabel 4.3.3.10. Verband tussen uitsteldur en ,karakter van de klacht wat betreft overwegend somatisch of psychisch; bij patiënten in de populatic met klachten van het bewegingsapparaat.

\begin{tabular}{cccccc}
\hline Uitstelduur & $\begin{array}{c}\text { Somatisch } \\
\%\end{array}$ & $\begin{array}{c}\text { Psycho- } \\
\text { somatisch } \\
\%\end{array}$ & $\begin{array}{c}\text { Psychisch } \\
\%\end{array}$ & $\begin{array}{c}\text { Matschappelijk } \\
\%\end{array}$ & $\begin{array}{c}\text { Totaal } \\
\%\end{array}$ \\
\hline 0 & 13 & 2 & 0 & 25 & 11 \\
1 & 35 & 28 & 27 & 25 & 33 \\
2 & 30 & 37 & 42 & 25 & 32 \\
3 & 22 & 33 & 31 & 25 & 24 \\
\hline Totaal & 100 & 100 & 100 & 100 & 100 \\
& $(\mathbf{N}=326)$ & $(\mathbf{N}=54)$ & $(\mathbf{N}=26)$ & $(\mathbf{N}=4)$ & $(\mathbf{N}=410)$ \\
\hline
\end{tabular}

Kendall's Tau $B=0,14 \quad P<0,001$ 
Tabel 4.3.3.1. Verband tussen witstelduur en ,karakter wan de klacht wat betreft overwegend somatisch of psychisch", bij patienten in de populatie met ,k.n.o.klachten of klachten van de luchtwegen?.

\begin{tabular}{cccccc}
\hline Uitsteldutir & $\begin{array}{c}\text { Somatisch } \\
\%\end{array}$ & $\begin{array}{c}\text { Psycho- } \\
\text { somatisch } \\
\%\end{array}$ & $\begin{array}{c}\text { Psychisch } \\
\%\end{array}$ & $\begin{array}{c}\text { Matschappelijk } \\
\%\end{array}$ & $\begin{array}{c}\text { Totaal } \\
\%\end{array}$ \\
\hline 0 & 11 & 8 & 9 & 0 & 11 \\
1 & 57 & 59 & 22 & 0 & 55 \\
2 & 22 & 22 & 39 & 100 & 23 \\
3 & 10 & 11 & 30 & 0 & 11 \\
\hline Totaal & 100 & 100 & 100 & 100 & 100 \\
& $(\mathrm{~N}=345)$ & $(\mathrm{N}=27)$ & $(\mathrm{N}=23)$ & $(\mathrm{N}=1)$ & $(\mathrm{N}=396)$ \\
\hline
\end{tabular}

Kendall's Tau $\mathrm{B}=0,13 \quad$ P $<0,01$

Tabel 4.3.3.12. Verbend tussen uitstelduur en ,karakter van de klacht wat betreft overwegend somatisch of psychisch", bij patiènten in de populatie met ,algemene klachten, huidklachten of klachten op sexualiteitsgebied".

\begin{tabular}{cccccc}
\hline Uitstelduur & $\begin{array}{c}\text { Somatisch } \\
\%\end{array}$ & $\begin{array}{c}\text { Psycho- } \\
\text { somatisch } \\
\%\end{array}$ & $\begin{array}{c}\text { Psychisch } \\
\%\end{array}$ & $\begin{array}{c}\text { Maatschappelijk } \\
\%\end{array}$ & $\begin{array}{c}\text { Totaal } \\
\%\end{array}$ \\
\hline 0 & 12 & 4 & 2 & 3 & 8 \\
1 & 32 & 23 & 19 & 9 & 26 \\
2 & 33 & 35 & 44 & 22 & 36 \\
3 & 23 & 38 & 35 & 66 & 30 \\
\hline Total & 100 & 100 & 100 & 100 & 100 \\
& $(\mathrm{~N}=350)$ & $(\mathrm{N}=79)$ & $(\mathrm{N}=190)$ & $(\mathrm{N}=32)$ & $(\mathrm{N}=651)$ \\
\hline
\end{tabular}

Kendall's Tau $B=0,23 \quad P<0,001$ 
Tabel 4.4.1.1. Verband tussen uitstelduur en artsen met relatief meer somatisch resp. meer psychisch gerichte interpretaties wan de klachten bil patiënten in de populatie.

\begin{tabular}{ccccc}
\hline & $\begin{array}{c}\text { Artsen met rellatief } \\
\text { meer somatische } \\
\text { klachten } \\
\%\end{array}$ & $\begin{array}{c}\text { Overige } \\
\text { artsen } \\
\%\end{array}$ & $\begin{array}{c}\text { Artsen met relatief } \\
\text { meer psychische } \\
\text { klachten } \\
\%\end{array}$ & $\begin{array}{c}\text { Totaal } \\
\%\end{array}$ \\
Uitstellduur & 15 & 8 & 7 & 9 \\
\hline 0 & 35 & 35 & 36 & 35 \\
1 & 26 & 32 & 25 & 30 \\
2 & 24 & 25 & 32 & 26 \\
3 & $100(\mathrm{~N}=395)$ & $100(\mathrm{~N}=1366)$ & $100(\mathrm{~N}=294)$ & $100(\mathrm{~N}=2055)$ \\
\hline Totaal & & &
\end{tabular}

Kendall's Tau $\mathrm{C}=0,05 \quad \mathbf{P}<0,01$

Tabel 4.4.1.2. Verband tussen uitstelduur en artsen met relatief meer somatisch resp. meer psychisch gerichte interpretaties van de klachten buj jongere patiënten in de populatie.

\begin{tabular}{ccccc}
\hline & $\begin{array}{c}\text { Artsen met relatief } \\
\text { meer somatische } \\
\text { klachten } \\
\%\end{array}$ & $\begin{array}{c}\text { Overige } \\
\text { artsen } \\
\%\end{array}$ & $\begin{array}{c}\text { Artsen met relatief } \\
\text { meer psychische } \\
k \| \text { achten } \\
\%\end{array}$ & $\begin{array}{c}\text { Totaal } \\
\%\end{array}$ \\
Uitstelduur & 17 & 9 & 8 & 10 \\
\hline 0 & 36 & 35 & 37 & 36 \\
1 & 25 & 33 & 27 & 30 \\
2 & 22 & 23 & 28 & 24 \\
3 & $100(\mathrm{~N}=261)$ & $100(\mathrm{~N}=877)$ & $100(\mathrm{~N}=201)$ & $100(\mathrm{~N}=1339)$ \\
\hline Total & & &
\end{tabular}

Kendall's Tau $C=0,06 \quad P<0,01$ 
Tabel 4.4.1.3. Verband tissen uitstelduur en artsen met relatief meer somatisch resp. meer psychisch gerichte interpretaties van de klachten bij oudere patienten in de populatie.

\begin{tabular}{ccccc}
\hline & $\begin{array}{c}\text { Artsen met relatief } \\
\text { meer somatische } \\
\text { klachten } \\
\%\end{array}$ & $\begin{array}{c}\text { Overige } \\
\text { artsen } \\
\%\end{array}$ & $\begin{array}{c}\text { Artsen met relatief } \\
\text { meer psychische } \\
\text { klachten } \\
\%\end{array}$ & $\begin{array}{c}\text { Totaal } \\
\%\end{array}$ \\
\hline 0 & 10 & 7 & 6 & 7 \\
1 & 35 & 34 & 33 & 34 \\
2 & 29 & 31 & 19 & 29 \\
3 & 26 & 28 & 42 & 30 \\
\hline Totaitstelduur & $100(\mathrm{~N}=124)$ & $100(\mathrm{~N}=479)$ & $100(\mathrm{~N}=89)$ & $100(\mathrm{~N}=692)$ \\
\hline
\end{tabular}

Kendall's Tau $\mathrm{C}=0,06 \quad \mathrm{P}<0,1$

Tabel 4.4.1.4. Verband tussen uitstelduur en artsen met relatief meer somatisch resp. meer psychisch gerichte interpretaties van de klachten bij mannen in de populatie.

\begin{tabular}{ccccc}
\hline & $\begin{array}{c}\text { Artsen met relatief } \\
\text { meer somatische } \\
\text { klachten } \\
\%\end{array}$ & $\begin{array}{c}\text { Overige } \\
\text { artsen } \\
\%\end{array}$ & $\begin{array}{c}\text { Artsen met relatief } \\
\text { meer psychische } \\
\text { klachten } \\
\%\end{array}$ & $\begin{array}{c}\text { Total } \\
\%\end{array}$ \\
\hline Uitstelduur & 22 & 10 & 10 & 13 \\
\hline 0 & 36 & 42 & 39 & 40 \\
1 & 27 & 29 & 23 & 28 \\
2 & 15 & 19 & 28 & 19 \\
3 & $100(\mathrm{~N}=174)$ & $100(\mathrm{~N}=552)$ & $100(\mathrm{~N}=144)$ & $100(\mathrm{~N}=870)$ \\
\hline Total & & $\mathrm{P}<0,01$ &
\end{tabular}


Tabel 4.4.1.5. Verband tussen uitstelduar en artsen met relatief meer somatisch resp. meer psychisch gerichte interpretaties van de klachten bij vrouwen in de populatie.

\begin{tabular}{ccccc}
\hline & $\begin{array}{c}\text { Artsen met relatief } \\
\text { meer somatische } \\
\text { klachten } \\
\%\end{array}$ & $\begin{array}{c}\text { Overige } \\
\text { artsen } \\
\%\end{array}$ & $\begin{array}{c}\text { Artsen met relatief } \\
\text { meer psychische } \\
\text { klachten } \\
\%\end{array}$ & $\begin{array}{c}\text { Total } \\
\%\end{array}$ \\
\hline 0 & 11 & 7 & 5 & 7 \\
1 & 33 & 30 & 32 & 31 \\
2 & 23 & 34 & 25 & 31 \\
3 & 33 & 29 & 38 & 31 \\
\hline Total & $100(\mathrm{~N}=208)$ & $100(\mathrm{~N}=805)$ & $100(\mathrm{~N}=146)$ & $100(\mathrm{~N}=1159)$ \\
\hline
\end{tabular}

Kendall's Tau $C=0,03 \quad P<0,1$

Tabel 4.4.1.6. Verband tussen uitstelduur en artsen met relatief meer somatisch resp. meer psychisch gerichte interpretaties van de klachten bij patiënten in de populatie met ,lagere opleidingen'.

\begin{tabular}{ccccc}
\hline & $\begin{array}{c}\text { Artsen met relatief } \\
\text { meer somatische } \\
\text { klachten } \\
\%\end{array}$ & $\begin{array}{c}\text { Overige } \\
\text { artsen } \\
\%\end{array}$ & $\begin{array}{c}\text { Artsen met rellatief } \\
\text { meer psychische } \\
\text { klachten } \\
\%\end{array}$ & $\begin{array}{c}\text { Totaal } \\
\%\end{array}$ \\
\hline 0 & 16 & 8 & 6 & 9 \\
1 & 33 & 36 & 41 & 37 \\
2 & 27 & 32 & 21 & 30 \\
3 & 24 & 23 & 32 & 24 \\
\hline Totaal & $100(\mathrm{~N}=257)$ & $100(\mathbb{N}=848)$ & $100(\mathrm{~N}=181)$ & $100(\mathrm{~N}=1286)$ \\
\hline
\end{tabular}

Kendall's Tau $\mathrm{C}=0,05 \quad \mathrm{P}<0,1$ 
Tabel 4.4.1.7. Verband tussen uitsteldum en artsen met relatief meer somatisch resp. meer psychisch gerichte interpretaties van de klachten bij patiënten in de populatie met ,midden opleidingen."

\begin{tabular}{ccccc}
\hline & $\begin{array}{c}\text { Artsen met relatief } \\
\text { meer somatische } \\
\text { klachten } \\
\text { Uitstelduur }\end{array}$ & $\begin{array}{c}\text { Owerige } \\
\text { artsen } \\
\%\end{array}$ & $\begin{array}{c}\text { Artsen met relatief } \\
\text { meer psychische } \\
\text { klachten } \\
\%\end{array}$ & $\begin{array}{c}\text { Totaal } \\
\%\end{array}$ \\
\hline 0 & 14 & 7 & 11 & 9 \\
1 & 38 & 35 & 29 & 34 \\
2 & 24 & 32 & 32 & 31 \\
3 & 24 & 26 & 28 & 26 \\
\hline Total & $100(\mathrm{~N}=97)$ & $100(\mathrm{~N}=397)$ & $100(\mathrm{~N}=79)$ & $100(\mathrm{~N}=573)$ \\
\hline
\end{tabular}

Kendall's Tau $C=0,05 \quad P<0,1$

Tabel 4.4.1.8. Verband tussen uitstelduur en artsen met relatief meer somatisch resp. meer psychisch gerichte interpretaties van de klachten bij patiënten in de populatie met ,hogere opleidingen".

\begin{tabular}{ccccc}
\hline & $\begin{array}{c}\text { Artsen met relatief } \\
\text { meer somatische } \\
\text { klachten } \\
\%\end{array}$ & $\begin{array}{c}\text { Overige } \\
\text { artsen } \\
\%\end{array}$ & $\begin{array}{c}\text { Artsen met relatief } \\
\text { meer psychische } \\
\text { klachten } \\
\%\end{array}$ & $\begin{array}{c}\text { Totaal } \\
\%\end{array}$ \\
\hline 0 & 10 & 12 & 3 & 10 \\
1 & 35 & 25 & 26 & 27 \\
2 & 25 & 31 & 26 & 29 \\
3 & 30 & 32 & 45 & 34 \\
\hline Totalstelduur & $100(\mathrm{~N}=40)$ & $100(\mathrm{~N}=111)$ & $100(\mathrm{~N}=31)$ & $100(\mathrm{~N}=182)$ \\
\hline
\end{tabular}

Kendall's Tau $C=0,09 \quad P<0,1$. 
Tabel 4.4.1.9. Verband tussen nitsteldwur en artsen met relatief meer somatisch resp. meer psychisch gerichte interpretaties van de klachten bij patiënten in de populatie met klachten van de luchtwegen.

\begin{tabular}{ccccc}
\hline & $\begin{array}{c}\text { Artsen met relatief } \\
\text { meer somatische } \\
\text { klachten } \\
\%\end{array}$ & $\begin{array}{c}\text { Overige } \\
\text { artsen } \\
\%\end{array}$ & $\begin{array}{c}\text { Artsen met relatief } \\
\text { meer psychische } \\
\text { klachten } \\
\%\end{array}$ & $\begin{array}{c}\text { Totalal } \\
\%\end{array}$ \\
\hline 0 & 11 & 7 & 0 & 7 \\
1 & 56 & 51 & 52 & 52 \\
2 & 33 & 29 & 14 & 27 \\
3 & 0 & 13 & 34 & 14 \\
\hline Totaal & $100(\mathrm{~N}=36)$ & $100(\mathrm{~N}=124)$ & $100(\mathrm{~N}=29)$ & $100(\mathrm{~N}=189)$ \\
\hline
\end{tabular}

Kendall's Tau $\mathrm{C}=0,14 \quad \mathrm{P}<0,01$

Tabel 4.4.1.10. Verband tussen uitstelduur en artsen met relatief meer somatisch resp. meer psychisch gerichte interpretaties van de kJachten bij patienten in de populatie met hartklachten.

\begin{tabular}{ccccc}
\hline & $\begin{array}{c}\text { Artsen met relatief } \\
\text { meer somatische } \\
\text { klachten } \\
\%\end{array}$ & $\begin{array}{c}\text { Overige } \\
\text { artsen } \\
\%\end{array}$ & $\begin{array}{c}\text { Artsen met relatief } \\
\text { meer psychische } \\
\text { klachten } \\
\%\end{array}$ & $\begin{array}{c}\text { Totaal } \\
\%\end{array}$ \\
\hline 0 & 36 & 11 & 0 & 11 \\
1 & 21 & 27 & 10 & 22 \\
2 & 29 & 25 & 20 & 24 \\
3 & 14 & 37 & 70 & 42 \\
\hline Totanl & $100(\mathrm{~N}=14)$ & $100(\mathrm{~N}=81)$ & $100(\mathrm{~N}=30)$ & $100(\mathrm{~N}=125)$ \\
\hline
\end{tabular}

Kendall's Tau $\mathrm{C}=0,31 \quad \mathbf{P}<0,001$ 
Tabel 4.4.2.1. Verband tussen uitstelduur en samenwerkingsvorm van artsen bij jongere patienten in de populatie.

\begin{tabular}{cccc}
\hline Uitstelddutr & $\begin{array}{c}\text { Solopraktijken } \\
\%\end{array}$ & $\begin{array}{c}\text { Associaties } \\
\%\end{array}$ & $\begin{array}{c}\text { Totaal } \\
\%\end{array}$ \\
\hline 0 & 12 & 5 & 10 \\
1 & 35 & 37 & 36 \\
2 & 29 & 34 & 30 \\
3 & 24 & 24 & 24 \\
\hline Total & $100(\mathbf{N}=996)$ & $100(\mathrm{~N}=349)$ & $100(\mathrm{~N}=1345)$ \\
\hline
\end{tabular}

Kendall's Tau $\mathrm{C}=0,05 \quad \mathrm{P}<0,1$

Tabel 4.4.2.2. Verband tussen uitstelduur en samenwerkingsvorm van artsen bij oudere patiënten in de populatie.

\begin{tabular}{cccc}
\hline Uitstelduur & $\begin{array}{c}\text { Solopraktijken } \\
\%\end{array}$ & $\begin{array}{c}\text { Associaties } \\
\%\end{array}$ & $\begin{array}{c}\text { Totaal } \\
\%\end{array}$ \\
\hline 0 & 6 & 9 & 7 \\
1 & 33 & 36 & 34 \\
2 & 28 & 30 & 29 \\
3 & 32 & 25 & 30 \\
\hline Totaal & $100(\mathrm{~N}=474)$ & $100(\mathrm{~N}=218)$ & $100(\mathrm{~N}=692)$ \\
\hline
\end{tabular}

Kendall's Tau $C=-0,07 \quad P<0,1$

Tabel 4.4.2.3. Verband tussen uitstelduur en samenwerkingsworm van artsen bij patiènten in de populatie met ,lagere opleidingen'.

\begin{tabular}{cccc}
\hline Uitstelduur & $\begin{array}{c}\text { Solopraktijken } \\
\%\end{array}$ & $\begin{array}{c}\text { Associaties } \\
\%\end{array}$ & $\begin{array}{c}\text { Totaal } \\
\%\end{array}$ \\
\hline 0 & 10 & 7 & 10 \\
1 & 34 & 44 & 36 \\
2 & 30 & 28 & 30 \\
3 & 26 & 21 & 24 \\
\hline Totaal & $100(\mathrm{~N}=994)$ & $100(\mathrm{~N}=295)$ & $100(\mathrm{~N}=1289)$ \\
\hline
\end{tabular}

Kendall's Tau $\mathrm{C}=-0,04 \quad \mathrm{P}<0,1$ 
Tabel 4.4.2.4. Verband tussen uitstelduur en samenwerkingsvorm van artsen bij patiënten in de populatie met, midden opleidingen".

\begin{tabular}{lccc}
\hline Uitstelduur & $\begin{array}{c}\text { Solopraktijken } \\
\%\end{array}$ & $\begin{array}{c}\text { Associaties } \\
\%\end{array}$ & $\begin{array}{c}\text { Totaal } \\
\%\end{array}$ \\
\hline 0 & 11 & 5 & 9 \\
1 & 36 & 30 & 35 \\
2 & 25 & 43 & 31 \\
3 & 27 & 21 & 26 \\
\hline Totaal & $100(\mathrm{~N}=405)$ & $100(\mathrm{~N}=169)$ & $100(\mathrm{~N}=574)$ \\
\hline Kendall's Tau $\mathrm{C}=0,05$ & $\mathrm{P}<0,1$ &
\end{tabular}

Tabel 4.4.2.5. Verband tussen uitstelduur en samenwerkingsvorm van artsen bij patienten in de populatie met, hogere opleidingen:

\begin{tabular}{cccc}
\hline Uitstelduur & $\begin{array}{c}\text { Solopraktijken } \\
\%\end{array}$ & $\begin{array}{c}\text { Associaties } \\
\%\end{array}$ & $\begin{array}{c}\text { Totalal } \\
\%\end{array}$ \\
\hline 0 & 11 & 9 & 10 \\
1 & 31 & 25 & 27 \\
2 & 32 & 26 & 28 \\
3 & 27 & 39 & 34 \\
\hline Total & $100(\mathrm{~N}=75)$ & $100(\mathrm{~N}=108)$ & $100(\mathrm{~N}=183)$ \\
\hline
\end{tabular}

Kendall's Tau $C=0,11 \quad P<0,1$

Tabel 4.4.2.6. Verband tussen uitsteldurur en samenwerkingsvorm van artsen bij patiënten in de populatie met k.n.o.-klachten.

\begin{tabular}{cccc}
\hline Uitstelduur & $\begin{array}{c}\text { Solopraktijken } \\
\%\end{array}$ & $\begin{array}{c}\text { Associaties } \\
\%\end{array}$ & $\begin{array}{c}\text { Totaal } \\
\%\end{array}$ \\
\hline 0 & 14 & 13 & 14 \\
1 & 61 & 47 & 57 \\
2 & 19 & 25 & 21 \\
3 & 6 & 16 & 9 \\
\hline Total & $100(\mathrm{~N}=155)$ & $100(\mathrm{~N}=64)$ & $100(\mathrm{~N}=219)$ \\
\hline
\end{tabular}

Kendall's Tau $\mathrm{C}=0,14 \quad \mathrm{P}<0,1$ 
Tabel 4.42.7. Verband tussen uitstelduw en samenwerkingsvorm van artsen bij patiếnten in de populatie met klachten van de luchtwegen.

\begin{tabular}{cccc}
\hline Uitstelduar & $\begin{array}{c}\text { Solopraktijken } \\
\%\end{array}$ & $\begin{array}{c}\text { Associaties } \\
\%\end{array}$ & $\begin{array}{c}\text { Totaal } \\
\%\end{array}$ \\
\hline 0 & 6 & 10 & 7 \\
1 & 47 & 65 & 52 \\
2 & 30 & 22 & 28 \\
3 & 17 & 4 & 14 \\
\hline Totaal & $100(\mathrm{~N}=138)$ & $100(\mathrm{~N}=51)$ & $100(\mathrm{~N}=189)$ \\
\hline
\end{tabular}

Kendall's Tau $\mathrm{C}=-0,20 \quad$ P $<0,01$

Tabel 4.4.2.8. Verband tussen uitstelduur en samenwerkingsvorm van artsen bij patienten in de populatie met hartklachten.

\begin{tabular}{cccc}
\hline Uitstelduur & $\begin{array}{c}\text { Solopraktijken } \\
\%\end{array}$ & $\begin{array}{c}\text { Associaties } \\
\%\end{array}$ & $\begin{array}{c}\text { Totaal } \\
\%\end{array}$ \\
\hline 0 & 9 & 15 & 11 \\
1 & 21 & 25 & 22 \\
2 & 19 & 35 & 24 \\
3 & 51 & 25 & 42 \\
\hline Totaal & $100(\mathrm{~N}=85)$ & $100(\mathrm{~N}=40)$ & $100(\mathrm{~N}=125)$ \\
\hline
\end{tabular}

Kendall's Tau $\mathrm{C}=-0,20 \quad P<0,1$

Tabel 4.4.2.9. Verband tussen uitstelduur en samenwerkingsworm wan artsen bij patienten in de populatie met klachten van het bewegingsapparaat.

\begin{tabular}{cccc}
\hline Uitsteldurr & $\begin{array}{c}\text { Solopraktijken } \\
\%\end{array}$ & $\begin{array}{c}\text { Associaties } \\
\%\end{array}$ & $\begin{array}{c}\text { Totaal } \\
\%\end{array}$ \\
\hline 0 & 13 & 5 & 11 \\
1 & 33 & 36 & 34 \\
2 & 32 & 31 & 32 \\
3 & 22 & 28 & 24 \\
\hline Totaal & $100(\mathrm{~N}=74)$ & $100(\mathrm{~N}=26)$ & $100(\mathrm{~N}=420)$ \\
\hline
\end{tabular}

Kendall's Tau $\mathrm{C}=0,08 \quad \mathrm{P}<0,01$ 
Tabel 4.4.2.10. Verband tussen uitstelduur en samenwerkingsvorm van artsen bij patiënten in de populatie met klachten op sexualiteitsgebied.

\begin{tabular}{cccc}
\hline Uitstelduur & $\begin{array}{c}\text { Solopraktijken } \\
\%\end{array}$ & $\begin{array}{c}\text { Associaties } \\
\%\end{array}$ & $\begin{array}{c}\text { Totaal } \\
\%\end{array}$ \\
\hline 0 & 5 & 0 & 4 \\
1 & 16 & 6 & 14 \\
2 & 25 & 22 & 25 \\
3 & 54 & 72 & 57 \\
\hline Totaal & $100(\mathrm{~N}=80)$ & $100(\mathrm{~N}=18)$ & $100(\mathrm{~N}=98)$ \\
\hline Kendall's Tau $\mathrm{C}=0,13$ & $\mathbf{P}<0,1$ &
\end{tabular}

Tabel 4.4.3.1. Verband tussen uitstelduur en spreekuurvorm bij patiënten in de populatie.

\begin{tabular}{cccc}
\hline Uitsteldurur & $\begin{array}{c}\text { Vrij } \\
\text { spreekuur } \\
\text { of }\end{array}$ & $\begin{array}{c}\text { Afspraak- } \\
\text { spreekuur } \\
\%\end{array}$ & $\begin{array}{c}\text { Totaal } \\
\%\end{array}$ \\
\hline 0 & 10 & 9 & 9 \\
1 & 30 & 37 & 35 \\
2 & 30 & 30 & 30 \\
3 & 30 & 24 & 26 \\
\hline Totaal & $100(\mathrm{~N}=589)$ & $100(\mathrm{~N}=1.473)$ & $100(\mathrm{~N}=2062)$ \\
\hline Kendall's Tau $\mathrm{C}=-0,06$ & $\mathbf{P}<0,01$ & &
\end{tabular}

Tabel 4.4.3.2. Verband tussen uitstelduur en spreekuurvorm bij jongere patiénten in de populatie.

\begin{tabular}{cccc}
\hline & $\begin{array}{c}\text { Vrij } \\
\text { spreekuur } \\
\%\end{array}$ & $\begin{array}{c}\text { Afspraak- } \\
\text { spreekuur } \\
\%\end{array}$ & $\begin{array}{c}\text { Total } \\
\%\end{array}$ \\
\hline 0 & 11 & 10 & 10 \\
1 & 31 & 37 & 36 \\
2 & 31 & 30 & 30 \\
3 & 26 & 22 & 24 \\
\hline Totatsteldural & $100(\mathrm{~N}=382)$ & $\mathbf{1 0 0}(\mathrm{N}=963)$ & $100(\mathrm{~N}=1345)$ \\
\hline
\end{tabular}

Kendall's Tau $\mathrm{C}=-0,05 \quad \mathrm{P}<0,1$ 
Tabel 4.4.3.3. Verband tussen uitsteluur en spreekuurvorm bij oudere patiënten in de populatie.

\begin{tabular}{cccc}
\hline & $\begin{array}{c}\text { Vrij } \\
\text { spreekuur } \\
\%\end{array}$ & $\begin{array}{c}\text { Afsprak- } \\
\text { spreekur } \\
\%\end{array}$ & $\begin{array}{c}\text { Totaal } \\
\%\end{array}$ \\
\hline Uitstelduur & 8 & 7 & 7 \\
1 & 27 & 37 & 34 \\
2 & 28 & 29 & 29 \\
3 & 38 & 27 & 30 \\
\hline Total & $100(\mathrm{~N}=196)$ & $100(\mathrm{~N}=496)$ & $100(\mathrm{~N}=692)$ \\
\hline Kendall's Tan C $=-0,10$ & $\mathrm{P}<0,01$ &
\end{tabular}

Tabel 4.4.3.4. Verband tussen uitstelduur en spreekuurvorm bij mannen in de populatie.

\begin{tabular}{cccc}
\hline & $\begin{array}{c}\text { Vrij } \\
\text { spreekuur } \\
\%\end{array}$ & $\begin{array}{c}\text { Afspraak- } \\
\text { spreekuur } \\
\%\end{array}$ & $\begin{array}{c}\text { Totaal } \\
\%\end{array}$ \\
Uitstelduur & 13 & 13 & 13 \\
\hline 0 & 35 & 42 & 40 \\
1 & 28 & 28 & 28 \\
2 & 25 & 17 & 20 \\
3 & $100(\mathrm{~N}=272)$ & $100(\mathrm{~N}=600)$ & $100(\mathrm{~N}=872)$ \\
\hline Total & $\mathrm{P}<0,01$ &
\end{tabular}

Tabel 4.4.3.5. Verband tussen uitstelduur en spreekuurvorm bij vrouwen in de populatie.

\begin{tabular}{cccc}
\hline Uitstelduur & $\begin{array}{c}\text { Vrij } \\
\text { spreekuur } \\
\%\end{array}$ & $\begin{array}{c}\text { Afspraak- } \\
\text { spreekuur } \\
\%\end{array}$ & $\begin{array}{c}\text { Totaal } \\
\%\end{array}$ \\
\hline 0 & 8 & 7 & 7 \\
1 & 26 & 33 & 31 \\
2 & 32 & 30 & 31 \\
3 & 34 & 29 & 30 \\
\hline Totagl & $100(\mathrm{~N}=315)$ & $100(\mathrm{~N}=849)$ & $100(\mathrm{~N}=1164)$ \\
\hline
\end{tabular}

Kendall's Tau $\mathrm{C}=-0,06 \quad \mathrm{P}<0,1$ 
Tabel 4.4.3.6. Verband tussen uitstelduur en spreekuurvorm bij patienten in de populatie met ,lagere opleidingen".

\begin{tabular}{cccc}
\hline Uitsteldurar & $\begin{array}{c}\text { Vrit } \\
\text { spreekur } \\
\%\end{array}$ & $\begin{array}{c}\text { Afspragk- } \\
\text { spreakuur } \\
\%\end{array}$ & $\begin{array}{c}\text { Totaal } \\
\%\end{array}$ \\
\hline 0 & 11 & 9 & 10 \\
1 & 30 & 39 & 36 \\
2 & 31 & 29 & 30 \\
3 & 29 & 23 & 24 \\
\hline Totaal & $100(\mathrm{~N}=380)$ & $100(\mathrm{~N}=909)$ & $100(\mathrm{~N}=1289)$ \\
\hline
\end{tabular}

Kendall's Tau $\mathrm{C}=-0,06 \quad \mathrm{P}<0,1$

Tabel 4.4.3.7. Verband tussen uitstelduur en spreekuurvorm bij patiënten in de populatie met , hogere opleidingen".

\begin{tabular}{cccc}
\hline & $\begin{array}{c}\text { Vrij } \\
\text { spreekuur } \\
\%\end{array}$ & $\begin{array}{c}\text { Afspraak } \\
\text { spreekur } \\
\%\end{array}$ & $\begin{array}{c}\text { Total } \\
\%\end{array}$ \\
\hline 0 & 5 & 11 & 10 \\
1 & 21 & 29 & 27 \\
2 & 31 & 28 & 28 \\
3 & 44 & 31 & 34 \\
\hline Total & $100(\mathrm{~N}=39)$ & $100(\mathrm{~N}=144)$ & $100(\mathrm{~N}=183)$ \\
\hline
\end{tabular}

Kendall's Tau $\mathrm{C}=-0,13 \quad \mathrm{P}<0,1$

Tabel 4.4.3.8. Verband tussen uitstelduur en spreekuurworm bij patiënten in de populatie met klachten van de luchtwegen.

\begin{tabular}{cccc}
\hline & $\begin{array}{c}\text { Vrij } \\
\text { spreekuur } \\
\text { Uitstelduur }\end{array}$ & $\begin{array}{c}\text { Afsprak } \\
\text { spreekuur } \\
\%\end{array}$ & $\begin{array}{c}\text { Totaal } \\
\%\end{array}$ \\
\hline 0 & 15 & 4 & 7 \\
1 & 35 & 57 & 52 \\
2 & 21 & 30 & 28 \\
3 & 29 & 9 & 14 \\
\hline Totaal & $100(\mathrm{~N}=48)$ & $100(\mathrm{~N}=141)$ & $100(\mathrm{~N}=189)$ \\
\hline
\end{tabular}

Kendall's Tau $C=-0,09 \quad P<0,1$ 
Tabel 4.43.9. Verband tussen uitstelduur en spreekuurvorm bij patienten in de populatie met hartklachten.

\begin{tabular}{cccc}
\hline & $\begin{array}{c}\text { Vrij } \\
\text { spreekur } \\
\text { Uitstelduur }\end{array}$ & $\begin{array}{c}\text { Afspraak- } \\
\text { spreekur } \\
\%\end{array}$ & $\begin{array}{c}\text { Totaal } \\
\%\end{array}$ \\
\hline 0 & 4 & 16 & 11 \\
1 & 15 & 27 & 22 \\
2 & 23 & 25 & 24 \\
3 & 58 & 32 & 42 \\
\hline Totaal & $100(\mathrm{~N}=52)$ & $100(\mathrm{~N}=73)$ & $100(\mathrm{~N}=125)$ \\
\hline Kendall's Tau $\mathrm{C}=-0,32$ & $\mathrm{P}<0,001$ &
\end{tabular}

Tabel 4.4.3.10: Verband tussen üutstelduur en spreekuurvorm bij patienten in de populatie met gezwellen.

\begin{tabular}{cccc}
\hline & $\begin{array}{c}\text { Vrij } \\
\text { spueekuur } \\
\%\end{array}$ & $\begin{array}{c}\text { Afspraak- } \\
\text { spreekuur } \\
\%\end{array}$ & $\begin{array}{c}\text { Totaal } \\
\%\end{array}$ \\
Uitstelduur & 10 & 4 & 5 \\
0 & 0 & 33 & 28 \\
1 & 40 & 39 & 39 \\
3 & 50 & 24 & 28 \\
\hline Total & $100(\mathrm{~N}=10)$ & $100(\mathrm{~N}=54)$ & $100(\mathrm{~N}=64)$ \\
\hline
\end{tabular}

Kendall's Tau $\mathrm{C}=-0,18 \quad \mathrm{P}<0,1$

Tabel 4.4.3.11. Verband tussen uitstelduur en spreekuurvorm bif patiënten in die populatie met huidiklachten.

\begin{tabular}{cccc}
\hline Uitstelduur & $\begin{array}{c}\text { Vrij } \\
\text { spreekuur } \\
\%\end{array}$ & $\begin{array}{c}\text { Afspraak- } \\
\text { spreekuur } \\
\%\end{array}$ & $\begin{array}{c}\text { Totaal } \\
\%\end{array}$ \\
\hline 0 & 2 & 11 & 9 \\
1 & 33 & 35 & 35 \\
2 & 36 & 36 & 36 \\
3 & 29 & 17 & 21 \\
\hline Totaal & $100(\mathbf{N}=45)$ & $100(\mathrm{~N}=105)$ & $100(\mathrm{~N}=150)$ \\
\hline
\end{tabular}

Kendall's Tau $\mathrm{C}=-0,16 \quad \mathrm{P}<0,1$ 
Tabel 4.4.4.1. Verband tussen uitstelduur en praktijkgrootte bij patienten in de populatie met algemene klachten.

\begin{tabular}{|c|c|c|c|c|c|}
\hline $\begin{array}{l}\text { Praktijkgrootte } \\
\text { Uitstelduur }\end{array}$ & $\begin{array}{c}>4000 \\
\text { patiënten } \\
\%\end{array}$ & $\begin{array}{c}3001 \text { tm. } 4000 \\
\text { patiènten } \\
\%\end{array}$ & $\begin{array}{c}2000 \text { t.m. } 3000 \\
\text { patienten } \\
\%\end{array}$ & $\begin{array}{c}<2000 \\
\text { patienten } \\
\%\end{array}$ & $\begin{array}{c}\text { Totalal } \\
\%\end{array}$ \\
\hline 0 & 13 & 5 & 9 & 15 & 8 \\
\hline 1 & 13 & 26 & 28 & 29 & 25 \\
\hline 2 & 33 & 41 & 38 & 35 & 39 \\
\hline 3 & 41 & 28 & 25 & 211 & 28 \\
\hline Totaal & $\begin{array}{c}100 \\
(\mathrm{~N}=39)\end{array}$ & $\begin{array}{c}100 \\
(\mathrm{~N}=211)\end{array}$ & $\begin{array}{c}100 \\
(\mathrm{~N}=138)\end{array}$ & $\begin{array}{c}100 \\
(\mathbb{N}=34)\end{array}$ & $\begin{array}{c}100 \\
(\mathrm{~N}=422)\end{array}$ \\
\hline
\end{tabular}

Tabel 4.4.4.2. Verband tussen uitstelduur en praktijkgrootte bij patiënten in de populatie met k.n.o.-klachten.

\begin{tabular}{cccccc}
\hline Praktijkgrootte & $\begin{array}{c}>4000 \\
\text { patiënten } \\
\%\end{array}$ & $\begin{array}{c}3001 \text { t.m. 4000 } \\
\text { patiënten } \\
\%\end{array}$ & $\begin{array}{c}2000 \text { t.m. 3000 } \\
\text { patiënten } \\
\%\end{array}$ & $\begin{array}{c}<2000 \\
\text { patiënten } \\
\%\end{array}$ & $\begin{array}{c}\text { Totaal } \\
\%\end{array}$ \\
\hline Uitstelduur & 6 & 21 & 9 & 4 & 14 \\
1 & 50 & 58 & 61 & 48 & 57 \\
2 & 39 & 16 & 20 & 28 & 21 \\
3 & 6 & 5 & 10 & 20 & 9 \\
\hline Totaal & 100 & 100 & 100 & 100 & 100 \\
& $(\mathbf{N}=18)$ & $(\mathrm{N}=99)$ & $(\mathbf{N}=77)$ & $(\mathbb{N}=25)$ & $(\mathbf{N}=219)$ \\
\hline
\end{tabular}

Kendall's Tau $B=0,13 \quad P<0,1$.

Tabel 4.4.4.3. Verband tussen uitstelduur en praktijkgrootte bij patiënten in de populatie met huidklachten.

\begin{tabular}{|c|c|c|c|c|c|}
\hline $\begin{array}{l}\text { Praktijkgrootte } \\
\text { Uitstelduur }\end{array}$ & $\begin{array}{c}>4000 \\
\text { patiënten } \\
\% \%\end{array}$ & $\begin{array}{c}3001 \text { t.m. } 4000 \\
\text { patiënten } \\
\%\end{array}$ & $\begin{array}{c}2000 \text { t.m. } 3000 \\
\text { patienten } \\
\%\end{array}$ & $\begin{array}{c}<2000 \\
\text { patienten } \\
\% \%\end{array}$ & $\begin{array}{c}\text { Totaal } \\
\%\end{array}$ \\
\hline 0 & 14 & 17 & 2 & 0 & 9 \\
\hline 1 & 21 & 46 & 29 & 27 & 35 \\
\hline 2 & 36 & 31 & 39 & 47 & 36 \\
\hline 3 & 29 & 7 & 31 & 27 & 21 \\
\hline Totaal & $\begin{array}{c}100 \\
\mathrm{~N}=14)\end{array}$ & $\begin{array}{c}100 \\
\mathrm{~N}=59)\end{array}$ & $\begin{array}{c}100 \\
(N=62)\end{array}$ & $\begin{array}{c}100 \\
(\mathrm{~N}=15)\end{array}$ & $\begin{array}{c}100 \\
(\mathrm{~N}=150)\end{array}$ \\
\hline
\end{tabular}

Kendall's Tau $B=0,24 \quad \mathbf{P}<0,001$ 
Tabel 4.4.5.1. Verband tussen uitstelduar en leeftijd huisarts bij patiënten in de populatie.

\begin{tabular}{lccc}
\hline $\begin{array}{l}\text { Leeftijd huisartsen } \\
\text { Uitsteld dour }\end{array}$ & $\begin{array}{c}40 \text { jaar } \\
\%\end{array}$ & $\begin{array}{c}40 \text { jaar } \\
\%\end{array}$ & $\begin{array}{c}\text { Totaal } \\
\%\end{array}$ \\
\hline 0 & 8 & 11 & 9 \\
1 & 39 & 31 & 35 \\
2 & 30 & 29 & 30 \\
3 & 23 & 29 & 26 \\
\hline Totaal & $100(\mathrm{~N}=1041)$ & $100(\mathrm{~N}=1021)$ & $100(\mathrm{~N}=2062)$ \\
\hline Kendall's Tau $\mathrm{C}=0,04$ & $\mathrm{P}<0,1$ &
\end{tabular}

Tabel 4.4.5.2. Verband tussen uitstelduur en leeftijd huisarts bij oudere patiënten in de populatie.

\begin{tabular}{cccc}
\hline $\begin{array}{c}\text { Leeftijd huisartsen } \\
\text { Uitstelduur }\end{array}$ & $\begin{array}{c}40 \text { jaar } \\
\%\end{array}$ & $\begin{array}{c}\geqslant 40 \text { jaar } \\
\%\end{array}$ & $\begin{array}{c}\text { Totaal } \\
\%\end{array}$ \\
\hline 0 & 6 & 8 & 7 \\
1 & 38 & 31 & 34 \\
2 & 31 & 27 & 29 \\
3 & 26 & 34 & 30 \\
\hline Totaal & $100(\mathrm{~N}=332)$ & $100(\mathrm{~N}=360)$ & $100(\mathrm{~N}=692)$ \\
\hline
\end{tabular}

Kendall's Tau $\mathrm{C}=0,07 \quad \mathrm{P}<0,1$

Tabel 4.4.5.3. Verband tussen uitstelduur en leeftijd huisarts bij vrouwen in de populatio.

\begin{tabular}{cccc}
\hline $\begin{array}{l}\text { Leeftijd huisartsen } \\
\text { Uitsteldum }\end{array}$ & $\begin{array}{c}40 \text { jaar } \\
\%\end{array}$ & $\begin{array}{c}\text { 40 jaar } \\
\%\end{array}$ & $\begin{array}{c}\text { Totaal } \\
\%\end{array}$ \\
\hline 0 & 6 & 8 & 7 \\
1 & 35 & 27 & 31 \\
2 & 30 & 32 & 31 \\
3 & 29 & 32 & 30 \\
\hline Totaal & $100(\mathrm{~N}=585)$ & $100(\mathrm{~N}=579)$ & $100(\mathrm{~N}=1164)$ \\
\hline
\end{tabular}

Kendall's Tau $\mathrm{C}=0,05 \quad \mathrm{P}<0,1$ 
Tabel 4.4.5.4. Verband tussen vitstelduur en leeftija huisarts bij patienten in de populatie met ,lagere opleidingen".

\begin{tabular}{cccc}
\hline $\begin{array}{l}\text { Leeftijd huisartsen } \\
\text { Uitstalduur }\end{array}$ & $\begin{array}{c}40 \text { jaar } \\
\%\end{array}$ & $\begin{array}{c}\geqslant 40 \text { jaar } \\
\%\end{array}$ & $\begin{array}{c}\text { Total } \\
\%\end{array}$ \\
\hline 0 & 8 & 11 & 10 \\
1 & 42 & 31 & 36 \\
2 & 29 & 30 & 30 \\
3 & 21 & 28 & 24 \\
\hline Totaal & $100(\mathrm{~N}=605)$ & $100(\mathrm{~N}=684)$ & $100(\mathrm{~N}=1289)$ \\
\hline
\end{tabular}

Kendall's Tau $C=0,07 \quad P<0,1$.

Tabel 4.4.5.5. Verband tussen uitstelduur en leeftijd huisarts bij patiënten in de populatie met klachten van de luchtwegen.

\begin{tabular}{lccc}
\hline $\begin{array}{l}\text { Leeftijd huisartsen } \\
\text { Uitstelduur }\end{array}$ & $<40$ jaar & $\begin{array}{c}40 \text { jaar } \\
\%\end{array}$ & $\begin{array}{c}\text { Totaal } \\
\%\end{array}$ \\
\hline 0 & 8 & 6 & 7 \\
1 & 59 & 46 & 52 \\
2 & 28 & 27 & 28 \\
3 & 6 & 21 & 1.4 \\
\hline Totaal & $100(\mathrm{~N}=90)$ & $100(\mathrm{~N}=99)$ & $100(\mathrm{~N}=189)$ \\
\hline
\end{tabular}

Kendall's Tau $\mathrm{C}=0,19 \quad \mathbf{P}<0,01$

Tabel 4.4.5.6. Verband tussen uitstelduur en leeftijd huisarts bij patienten in de populatie met huidklachten.

\begin{tabular}{lccc}
\hline $\begin{array}{l}\text { Leeftijd huisartsen } \\
\text { Uitstelduur }\end{array}$ & $\begin{array}{c}<0 \text { jaar } \\
\%\end{array}$ & $\begin{array}{c}\text { 40 jaar } \\
\%\end{array}$ & $\begin{array}{c}\text { Totaal } \\
\%\end{array}$ \\
\hline 0 & 8 & 9 & 9 \\
1 & 42 & 25 & 35 \\
2 & 39 & 31 & 36 \\
3 & 11 & 34 & 21 \\
\hline Totaal & $100(\mathrm{~N}=89)$ & $100(\mathrm{~N}=61)$ & $100(\mathrm{~N}=150)$ \\
\hline Kendall's Tau $\mathrm{C}=0,22$ & $\mathrm{P}<0,01$
\end{tabular}




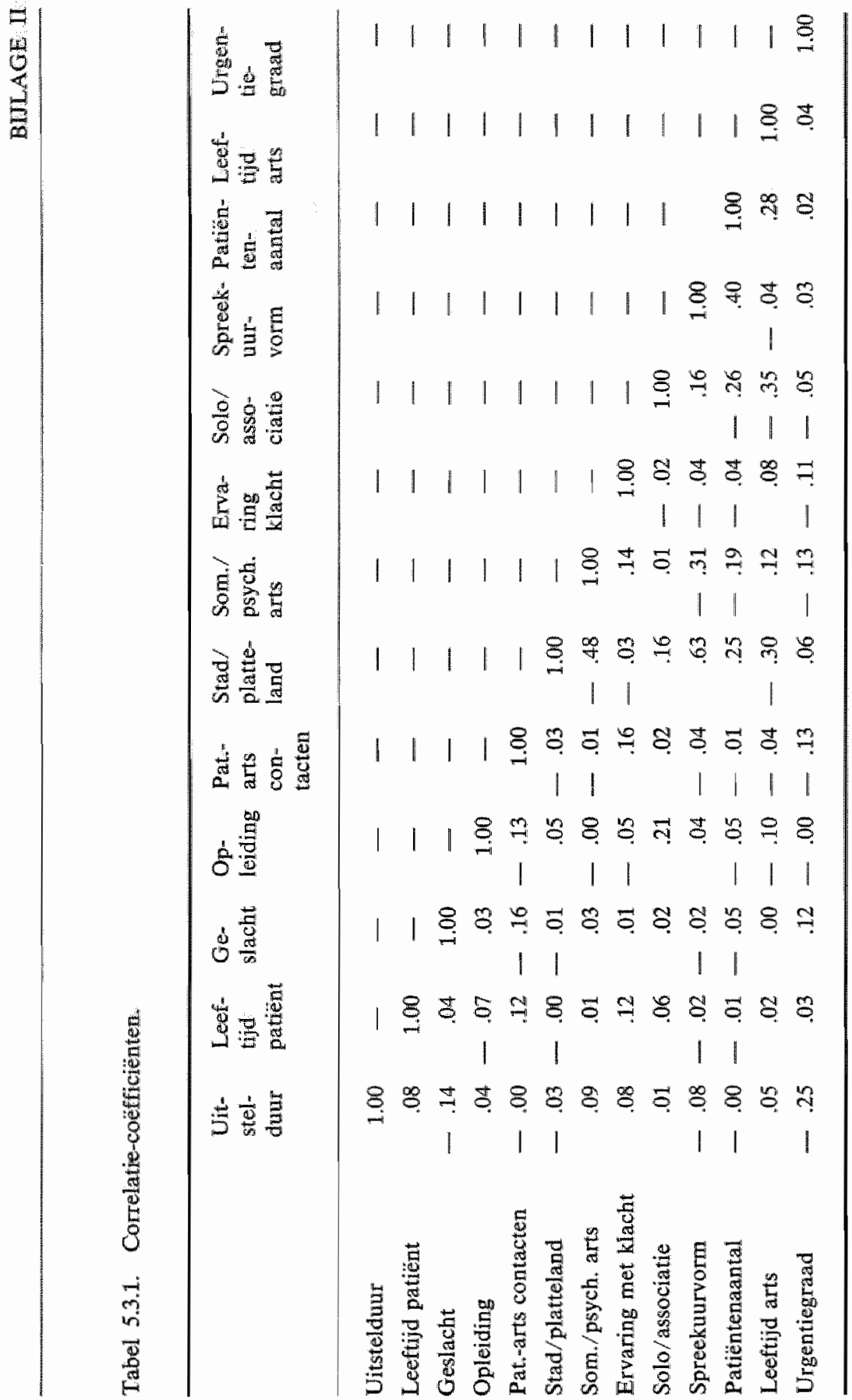


Tabel 5.3.4. Stapsgewijze regressieanalyse bij klachten met een laagste urgentie$\operatorname{graad}(=3)$

\begin{tabular}{|c|c|c|c|}
\hline \multirow[b]{2}{*}{ Onafhankelijk } & \multicolumn{2}{|c|}{ Thankelijk: De uitsteldunr } & \multirow{2}{*}{$\begin{array}{c}\text { Correlatie } \\
\text { O-orde }\end{array}$} \\
\hline & Bèta & $\mathbf{F}$ & \\
\hline Geslacht patiënt & -.18 & 7.66 & -.16 \\
\hline Som./psych. arts & -.17 & 4.31 & -.12 \\
\hline Pat.-arts contacten & -.13 & 3.31 & -.07 \\
\hline Spreekuurworm & -.12 & 1.66 & .02 \\
\hline Patièntenaantal & .11 & 1.95 & .10 \\
\hline Opleiding patiënt & .09 & 1.97 & .08 \\
\hline Leeftijid patiënt & .08 & 1.37 & .04 \\
\hline Stad/platteland & -.08 & .64 & .02 \\
\hline Ervaring met klacht & .06 & .74 & .01 \\
\hline Leeftijd arts & -.06 & .61 & .01 \\
\hline Solo/associatie & -.05 & .49 & -.07 \\
\hline
\end{tabular}

$\mathrm{N}=228$

Multipele $\mathrm{R}=.28$

$\mathrm{R}^{2}=.08$

$F=1.82$

Tabel 5.3.5. Stapsgewijze regressieanalyse bij klachten met een lage urgentie$\operatorname{graad}(=4)$.

\begin{tabular}{|c|c|c|c|}
\hline \multirow[b]{2}{*}{ Onafhankelijk } & \multicolumn{2}{|c|}{ 1fhankelijk: De uitstelduur } & \multirow{2}{*}{$\begin{array}{c}\text { Correlatie } \\
\text { O-orde }\end{array}$} \\
\hline & Bèta & $\mathbf{F}$ & \\
\hline Stad/platteland & .32 & 18.38 & .03 \\
\hline Spreekuurvorm & -.28 & 14.47 & -.11 \\
\hline Leeftijd arts & .21 & 9.72 & .15 \\
\hline Som./psych. arts & .19 & 9.57 & .14 \\
\hline Geslacht patiënt & -.12 & 5.21 & -.14 \\
\hline Opleiding patiënt & .12 & 4.63 & .06 \\
\hline Ervaring met klacht & .11 & 4.11 & .16 \\
\hline Leeftijd patiënt & .08 & 2.11 & .09 \\
\hline Patientenaantal & .07 & 1.21 & .05 \\
\hline Solo/associatie & .05 & .46 & -.06 \\
\hline Pat,-arts contacten & .02 & .13 & .06 \\
\hline \multicolumn{4}{|l|}{$N=309$} \\
\hline \multicolumn{4}{|l|}{ Multipele $\mathbf{R}=.39$} \\
\hline \multicolumn{4}{|l|}{$\mathbb{R}^{2}=.15$} \\
\hline$F=4.92$ & & & \\
\hline
\end{tabular}


Tubel 5.3.6. Stapsgewijze regressieanalyse bij klachten met een gemiddelde urgentiegraad $(=5)$.

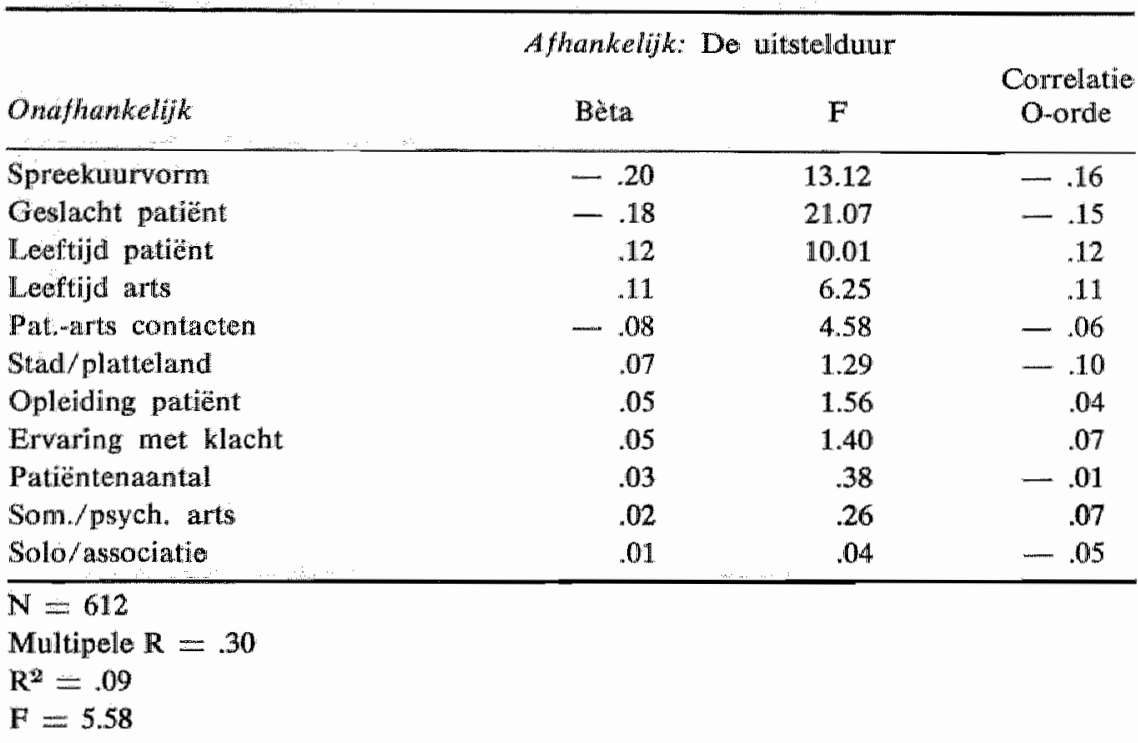

Tabel 5.3.7. Stapsgewijze regressieanalyse bij klachten met een hoge urgentiegraad $(=6)$

\begin{tabular}{lccc}
\hline & Afhankelijk: De uitstelduur & \\
Onafhankelijk & Bèta & F & $\begin{array}{c}\text { Correlatie } \\
\text { O-orde }\end{array}$ \\
\hline Som./psych. arts & .13 & 4.39 & .09 \\
Put.-arts contacten & -.10 & 3.20 & -.09 \\
Solo/associatie & .09 & 2.41 & .12 \\
Stad/platteland & .06 & .84 & .03 \\
Geslacht patient & -.05 & .83 & -.04 \\
Leoflijd patiënt & .05 & .74 & .02 \\
Leeftijd arts & -.05 & .55 & -.07 \\
Ervaring met klacht & -.02 & .17 & -.03 \\
Patiëntenaantal & -.01 & .01 & -.06 \\
Spreekuurvorm & .01 & .01 & \\
Opleiding patiënt & .00 & .00 & \\
\hline
\end{tabular}

$N=377$

Multipele $\mathrm{R}=.20$

$\mathrm{R}^{2}=.04$

$\mathrm{F}=1.69 \mathrm{n.s}$. 
Tabel 5.3.8. Stapsgewijze regressieanalyse bij klachten met een hoogste urgentie$\operatorname{graad}(=7)$.

\begin{tabular}{|c|c|c|c|}
\hline \multirow[b]{2}{*}{ Onafhankelijk } & \multicolumn{2}{|c|}{ fhankeliyk: De uitstelduur } & \multirow{2}{*}{$\begin{array}{l}\text { Correlatie } \\
\text { O-orde }\end{array}$} \\
\hline & Bèta & $\mathrm{F}$ & \\
\hline Leeftijd patient & .23 & 6.82 & .21 \\
\hline Leeftijd arts & .16 & 2.84 & .09 \\
\hline Solo/associatie & .16 & 2.92 & .08 \\
\hline Ervaring met klacht & .11 & 1.49 & .11 \\
\hline Geslacht patiënt & -.07 & .62 & -.05 \\
\hline Som./psych. arts & -.07 & .61 & -.03 \\
\hline Spreekuurvorm & .03 & .14 & .01 \\
\hline Pat.-arts contacten & .02 & .05 & .06 \\
\hline Opleiding patiënt & .02 & .05 & .02 \\
\hline Patiëntenaantal & .00 & .00 & \\
\hline Stad/platteland & .00 & .00 & \\
\hline
\end{tabular}

$\mathrm{N}=120$

Multipele $\mathrm{R}=.31$

$\mathrm{R}^{2}=.09$

$\mathrm{F}=1.39$ n.s. 


\section{AID - AUTOMATIC INTERACTION DETECTION}

AID is a multivariate technique for determining the value of a dependent variable as a combination of independent variables. The object is to classify observations (people, objects, etc.) in mutually exclusive groups so the observations in a group are similar to one another, yet different from the observations in the other groups. This program differs from multiple regression and stepwise regression in that no assumptions are made about the linearity of the model and that the independent variables may exhibit interaction and/or be nominally scaled.

\section{PROCEDURE DEFINITION INFORMATION}

ANALYSIS PROGRAM NAME. This program is referenced by AID. INPUT STATEMENTS. The input statement used with the program is INPUT GROUP. The predictor variables are specified in the statement with the last variable in the group serving as the dependent variable. OUTPUT REPORTS. This program has three output reports available:

a. MAIN (default) report.

b. DETAIL (optional) report.

c. RESIDUALS (optional) report.

\section{MAIN (Default) Report}

The MAIN report gives a listing of all predictors used in the analysis, their maximum and minimum values, and their type (free or monotonic). The group split (eligibility and reducibility criteria), the maximum number of allowable groups, the minimum size of a group and the mean, standard deviation, sum and sum of the squares of the dependent variables are also given. The total sum of the squares (TSS) for the analysis; the PA, the minimum sum of the squares (TSS) that must be contained in a group before it is eligible to be split; and the $\mathrm{PB}$, the minimum sum of the squares (TSS) that must be transferred from within a group to between-group sums of squares for a split to take place, are included. A summary description of each group created during the partitioning process is given by the following: 
a. Group identification number.

b. Identification number of the group from which it is split.

c. Identification of the variable on which the split is made.

d. The codes of the partitioning variable comprising the group.

e. An asterisk (*) to indicate terminal groups (i.e., groups that are not split further).

f. The number $(\mathrm{N})$ of observations in the group.

g. The mean value (Y) of the dependent variable for each group.

A one-way analysis of variance table for final groups is also generated.

\section{DET AIL (Optional) Report}

The DETAIL report provides a record of the statistics for all attempted partitions. For each attempted partition, the statistics include:

a. The number $(\mathbb{N})$ of observations in each class.

b. The mean value (Y) of the dependent variable in each class.

c. The standard deviation of the dependent variable in each class.

d. The between-group sums of squares (BSS) for each possible partition between adjacent classes.

e. The total sum of squares (TSS) in the group for each attempted partition.

\section{RESIDUALS (optional) Report}

The RESIDUALS output provides for each observation the observed, the predicted, and the residual value of the dependent variable.

OPTION STATEMENTS. There are no OPTION statements associated with this program.

ASSIGNMENT STATEMENTS. The four assigment parameters associated with the program are: MINISIZE, MAXGROUP, SELIGIBLE, and SREDUCE.

a. MINSIZE. The MINSIZE parameter establishes the minimum number of observations that may be contained in a group which is to be a candidate for splitting. (Default value is 25).

b. MAXGROUPS. MAXGROUPS establishes the maximum number of groups that may be created. (Default value is 50 ). The range is: $1 \leqslant$ MAXGROUPS $\leqslant 64$. 
c. SELIGIBLE. SELIGIBLE states the percentage of the total sum of the squares (TSS) that a group must contain if it is to be eligible for splitting (split eligibility criteria). (Default value is .00001. This essentially deactivates the parameter). This requirement prevents groups with little variation from being solit.

d. SREDUCE. SREDUCE states the percentage of the total sum of the squares (TSS) which a candidate group must explain before it may be created (split reducibility criteria). (Default value is .01.). ATTRIBUTE STATEMENTS. The only attribute statement associated with this program is FREE. FREE is a list of those independent variables which do not have a natural order and so may have their classes rearranged during the partitioning process.

The general attribute statements of SEQUENCE, ORDER and WEIGHT also apply to this program.

\section{RESTRICTIONS}

The following restrictions apply to AID:

a. The maxium number of predictors is 39 .

b. Predictor variables may assume up to 99 distinct values.

\section{NOTES}

Independent variables may be treated as being either free or monotonic: BASIS assumes all independent variables are monotonic unless otherwise specified via the attribute statement. Monotonic variables, such as income classes or age of household, have natural order. In this case, for example, if the split is at the $\$ 10.000$ income level, all observations with less than $\$ 10.000$ income level are in one group and all observations with more than $\$ 10.000$ income are in the other group. Free variables, such as nationality or marital status, have no natural order. In this case, the groups of observations falling in various classes are sorted in descending sequence using the mean value of the dependent variable or a key. The resulting split optimally divides the classes by combining the members of the different classes according to the value of the dependent variable. 



\section{Curriculum vitae}

De schrijwer van dit proefschrift werd op 12 oktober 1939 geboren te Heer. Hij bezocht de Katholieke Hogere Burger School (nu St. Maartenscollege) te Maastricht en behaalde in 1959 het eindexamen H.B.S.-B. Daarna studeerde hij geneeskunde aan de Katholieke Universiteit te Nijmegen, welke studie onderbroken werd voor het vervullen van de militaire dienstplicht. In oktober 1965 werd de studie hervat, waarna in maart 1968 het kandidaatsexamen werd behaald, in mei 1970 het doctoraal examen en in mei 1972 het artsexamen.

Sinds juli 1972 is hij als huisarts werkzaam in de gemeente Gulpen. In 1974 werd hij in het huisartsenregister ingeschreven.

Vanaf 1975 is hij aldaar, onder leiding van Professor Dr. W. Brouwer, hoogleraar huisartsgeneeskunde, en Professor Dr. H. Phillipsen, hoogleraar medische sociologie, van de Faculteit der Geneeskunde, Rijksuniversiteit Limburg te Maastricht, aan dit proefschrift werkzaam geweest. 